Division of Geological \& Geophysical Surveys

\author{
MISCELLANEOUS PUBLICATION 42
}

Opportunities in Alaska Coalbed Methane

Anchorage Alaska

March 1-3, 2000

Guidebook

February 2001

THIS REPORT HAS NOT BEEN REVIEWED FOR

TECHNICAL CONTENT OR FOR CONFORMITY TO THE

EDITORIAL STANDARDS OF DGGS

\author{
Released by
}

STATE OF ALASKA

DEPARTMENT OF NATURAL RESOURCES

Division of Geological \& Geophysical Surveys

794 University Avenue, Suite 200

Fairbanks, Alaska 99709-3645 


\section{Opportunities in Alaska Coalbed Methane Anchorago, Alaska = March 1-3, 2000}

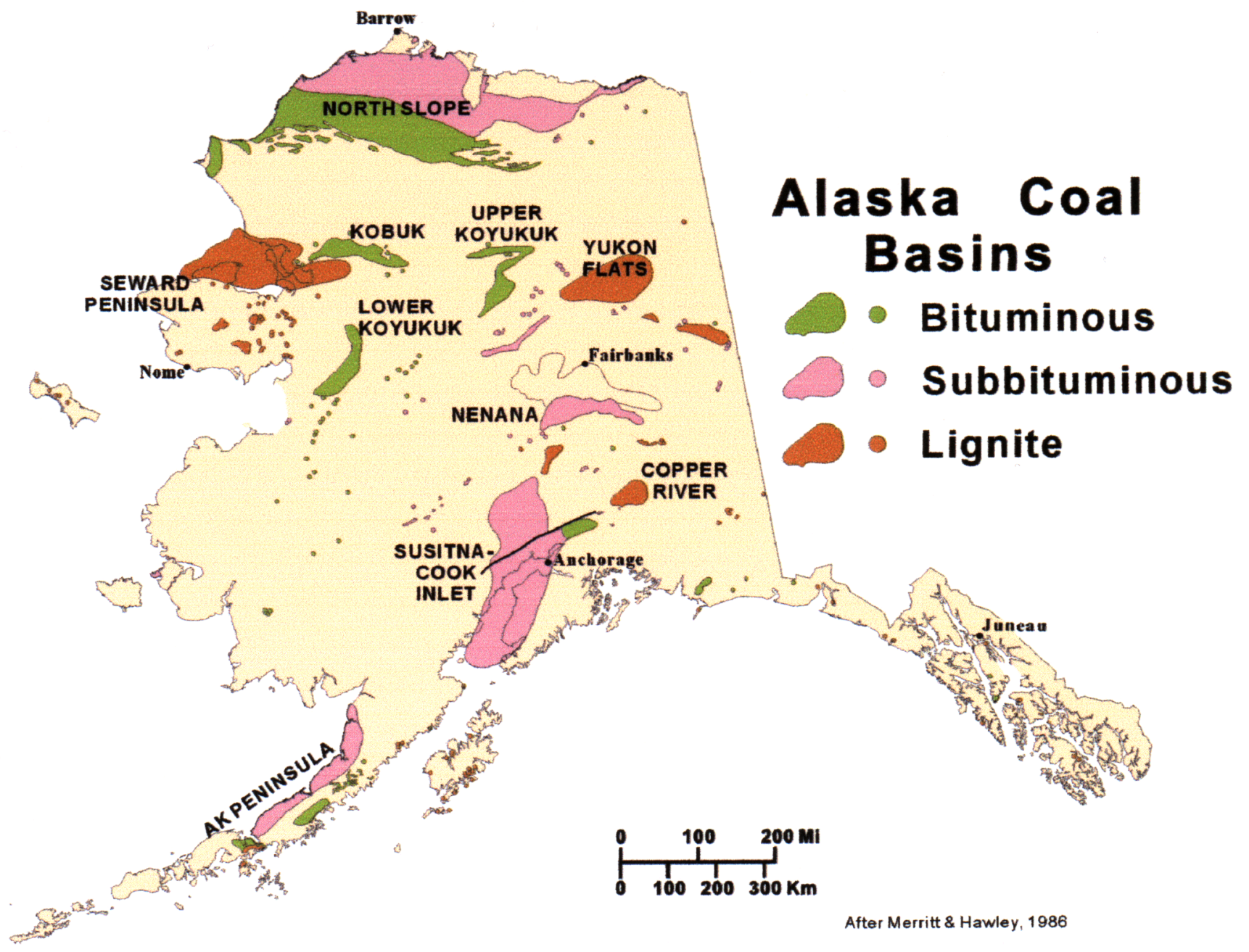

ORGANIZED BY:

West Coast PTTC

Alaska Department of Natural Resources

U.S. Geological Survey

CO-SPONSORED BY:

U.S. Department of Energy

U.S. Bureau of Land Management

University of Alaska Fairbanks

Arctic Slope Regional Corporation

University of Southern California 
Opportunities in Alaska Coalbed Methane Short Course

“Coalbed Methane from Prospect to Production"

\author{
Instructors \\ Charles E. Barker, U.S. Geological Survey \\ Robert A. Downey, Energy Ingenuity Co. \\ Andrew A. Scott, Texas Bureau of Economic Geology \\ Schedule and Topics
}

8:00 a.m. Registration, Coffee, Distribution of Notes

8:15 Introduction of Speakers

Overview of Course Organization

8:20 Basic Chemistry of Gas Sorption

CBM Resources and World Distribution

Typical Reservoir Characteristics

Origin of Coal and Coal Properties

10:00 Coffee Break

10:30 CBM Producibility Model

12:00 Lunch

1:00 p.m. CBM Reservoir Engineering/Production

2:00 CBM Economics

2:45 Coffee Break

3:00 Application of Producibility Model to Alaska

3:30 Discussion

4:00 Adjourn 


\section{DAY 2}

\section{Opportunities in Alaska Coalbed Methane}

Field Trip

Cook Inlet, Alaska State Geological Materials Center, Pioneer and Houston CBM projects

Thursday, March 2, 2000 


\section{Coalhed Methane Workshop}

Friday, March 3, 2000

8:00 a.m. - 5:00 p.m.

\section{AGENDA}

8:00 a.m. Registration

8:30 Welcoming Address

\section{Program Review}

9:10 Technical Program:

\section{Overview of Coalbed Methane Resources in Alaska}

- The Potential for developing coalbed methane exploration fairways and sweet spots along the North Slope of Alaska

- A case study on the "Pioneer Project"

- Evaluation of rural Alaska coalbed gas test drilling demonstration sites, from paper to reality

10:10 Break

\section{Panel Sessions:}

\section{Land issues, Coalbed Gas Exploration on State, Federal and Native Corporation Lands}

- State of Alaska's shallow gas leasing program

- CBM exploration and development on Federal lands

- Alaska Regional Native Corporation Lands

\section{2:00 Luncheon}

1:30 p.m Panel Sessions:

\section{Advances in Exploration Methods:}

- Conventional traps and seals as critical elements in the preservation of shallow coalbed methane prospects within Rocky Mountain Foreland and Laramide Basins

- Shallow gas exploration for Red Dog mine gas-based power generation (Author: John Kelafant)

- Remote sensing exploration for shallow gas

- Coalbed methane exploration in Alaska using limited data and creative approaches

\section{Drilling, Production and Reservoir Studies:}

- Guidelines for designing water disposal systems for coalbed methane production in Alaska.

- Microhole Drilling and Instrumentation Technology

- A potential method for assessing coalbed methane resources using high-resolution chronostratigraphy, vitrinite reflectance and burial history modeling, Cook Inlet, Alaska (Poster)

- Evaluation Of Coal Bed Methane Prospects Near Wainwright., Alaska, Using Burial History Modeling Of The Western National Petroleum Reserve In Alaska (NPR4) (Poster) Break

\section{Q \& A With Workshop Speakers}

\section{Conclusions and Wrap-up}

Adjourn
John Shively, Commissioner, Alaska Department of Natural Resources Leo Schrider, PTTC Board Chairman

Jim Clough, Alaska Div. of GeoZogicaZ \& Geophysical Surveys

Iraj Ershaghi, Director, West Coast PTTC

Roger Tyler, Arc Group LLC

Andrew Scott Texas BEG

J. G. Clough, $A D G G S$

R.A. Downey, Ocean Energy and Dan Seamount, UNOCAL

J. G. Clough, Alaska Div. of Geological \& Geophysical Surveys C.E. Barker and A.C. Clark, US Geological Survey
Pirtle Bates, Alaska Div. of Oil and Gas

Bob Fisk U.S. Bureau of Land Management, Alaska

Norm Phillips, Doyon Limited

Nick Enos, Calista Corporation

Teresa Imm, Arctic Slope Regional Corporation

Wes Nason, Ahtna Corporation

Paul Roehl, Bristol Bay Native Corporation

JoeGreen,Representative-AlaskaStateLegislature

C.E. Barker, U.S. Geological Survey

Scott Reeves, Advanced Resources International

David W. Lappi, President, LAPP Resources, Inc.

Andrew R. Scott , Bureau of Economic Geology, The University of Texas at Austin

David O. Ogbe, University ofAlaska Fairbanks

Jim Albright, Los Alamos National Laboratory

Todd A. Dallegge, University ofAlaska Fairbanks

Ron Tingook, Arctic Slope Regional Corporation and C.E. Barker, U.S. Geological Survey 


\section{Alaska Coalbed Methane Workshop}

\section{What does $1000 \mathrm{TSCF}$ of}

Coalbed gas mean in terms of Oil

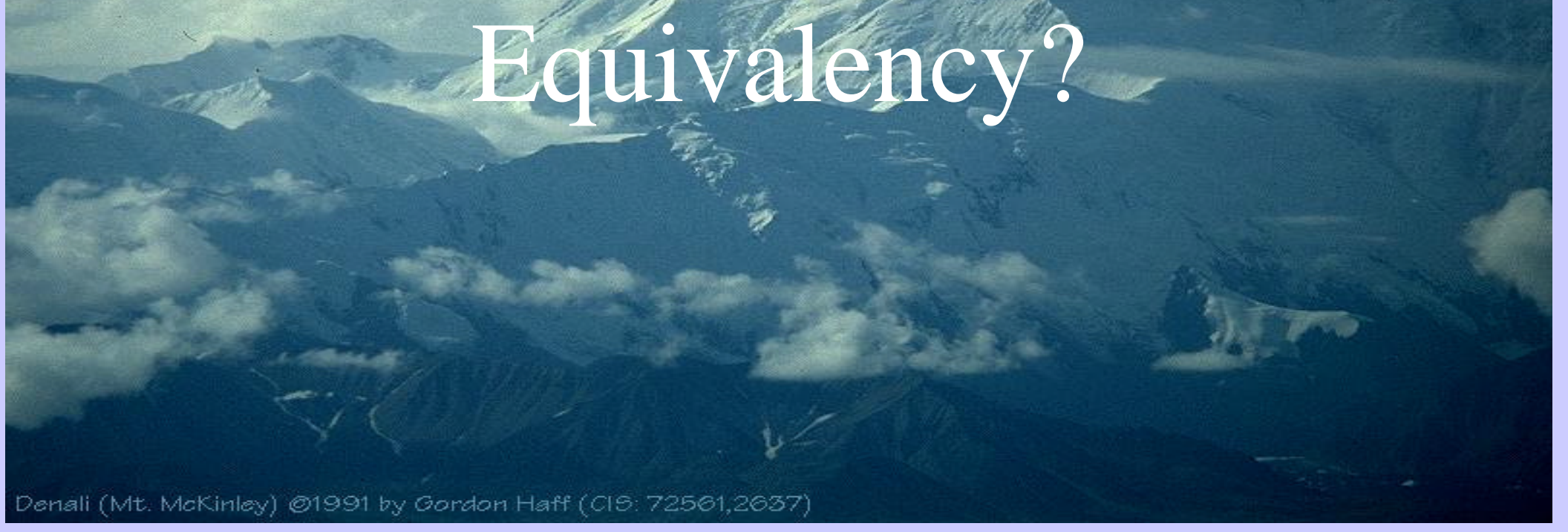

March 1-3, 2000 Anchorage, AK 


\section{Alaska Coalbed Methane Workshop}

\section{Billion Barrels \\ (6 times the Current Oil Reserves in the U.S.)}




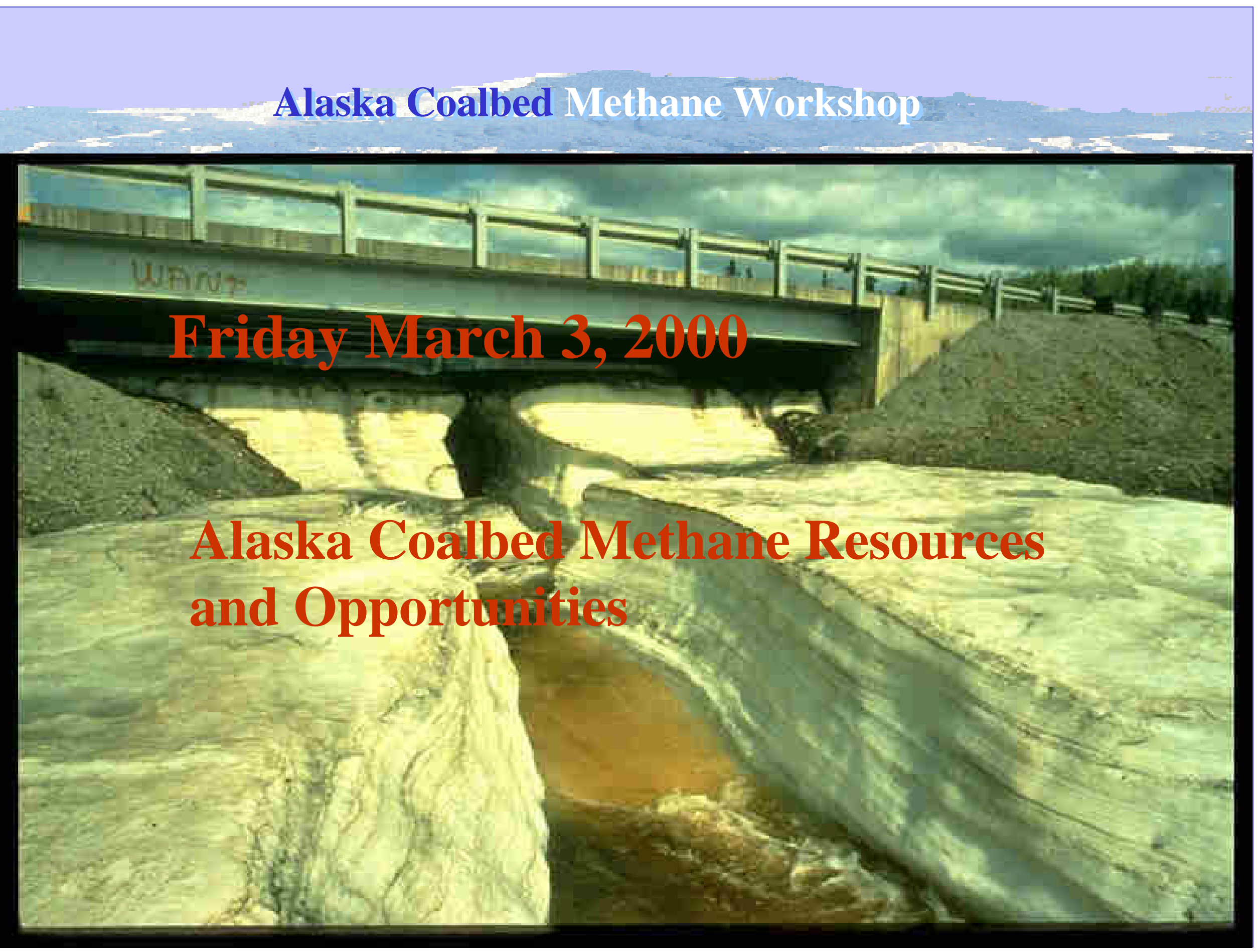




\section{Alaska Coalbed Methane Workshop}

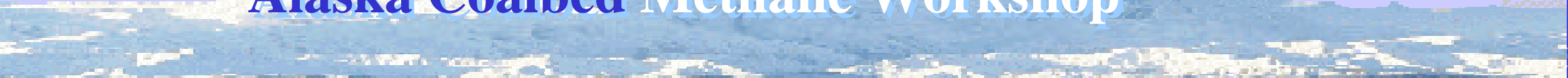

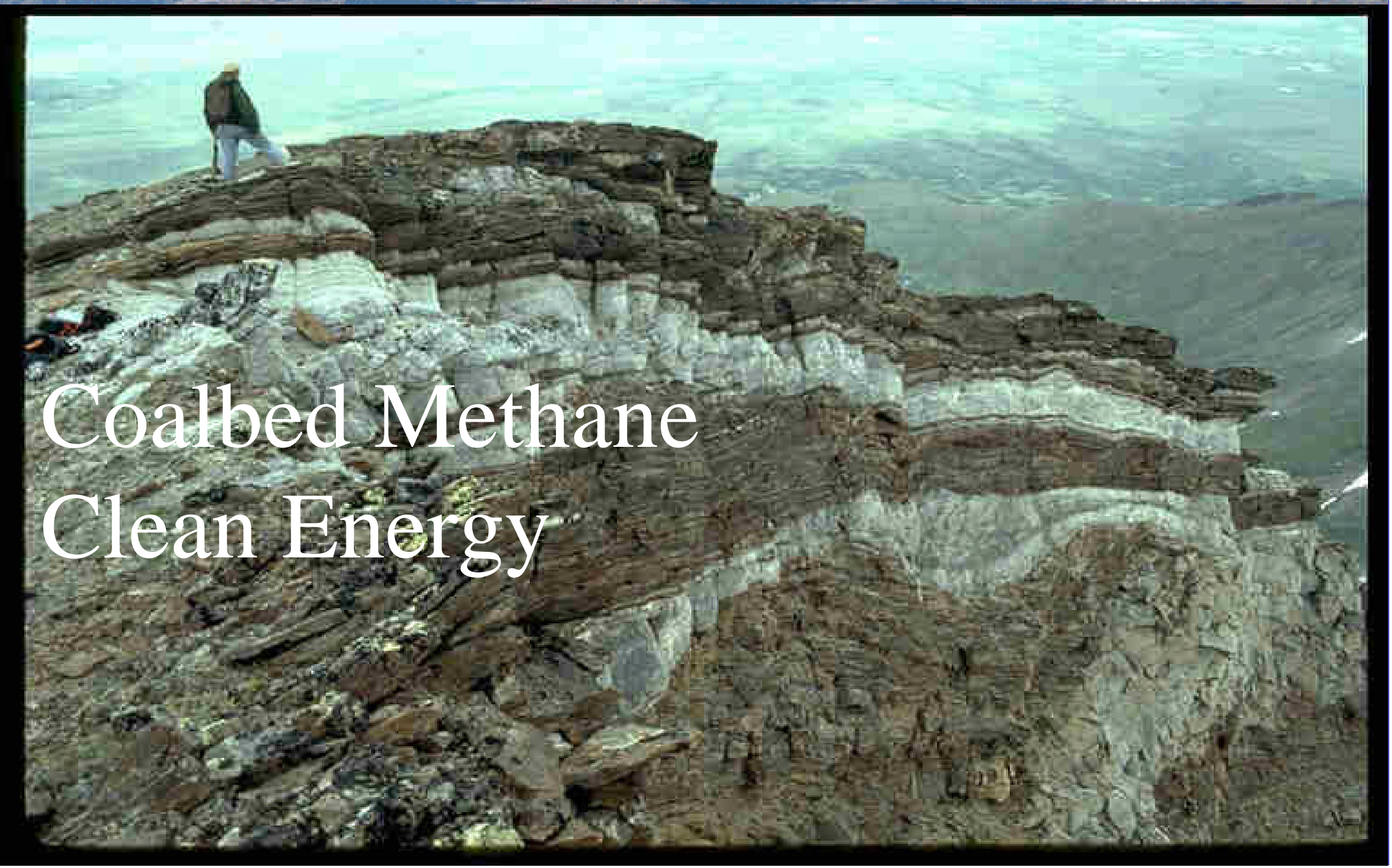




\section{Alaska Coalbed Methane Workshop}

\section{PTTC Coalbed Methane Workshops}

- 12 CBM Workshops

- 9 Regions

- 1428 participants 


\section{Alaska Coalbed Methane Workshop:}

\section{Program Objectives}

- Resource Type and Location

- Necessity for Development

- State of Technology

- Economics

- Incentives

- Action Plan

- Next Step 


\section{Alaska Coalbed Methane Workshop}

\section{Program at a glance}

Resource Definition

Panel Session

Luncheon Speaker

Technology Issues

Q \& A

Conclusions and Wrap-up

Workshop Evaluation

March 1-3, 2000 Anchorage, AK 


\section{Welcoming Address}

John T. Shively

Commissoner, Alaska Department of Natural Resources

Leo Schrider

PTTC, Board Chairman 


\section{Speaker Biography}

\section{John T. Shively}

John Shively became Commissioner of the Alaska Department of Natural Resources on February 8,1995 at the age of 51 . He grew up on a dairy farm in upstate New York, attended school in Watertown, Connecticut and graduated from the University of North Carolina, Chapel Hill. Mr. Shively began his public service as a VISTA volunteer in Alaska in 1965.

He worked as a health planner both in Anchorage and rural Alaska, and was Deputy Director, and later Executive Director of Rural Alaska Community Action Programs from 1969 to 1972. He was Executive Vice president of the Alaska Federation of Natives from 1972 to 1975 . He served the NANA Regional Corporation first as Vice President of Operations from 1975 to 1983, then as Senior Vice President from 1986 to 1992 and finally as Senior Vice President and Chief Operating Officer for it's development Corporation from 1992 to 1994.

Alaskan Governor Bill Sheffield tapped Mr. Shively for his Chief of Staff in 1983. He left that position in 1985, doing consulting work for a number of clients until his return to NANA in 1986. He also took on the challenge of Chairman and CEO of the United Bancorporation Alaska, Inc. and United Bank of Alaska during 1987-88. Just prior to his return to public service as commissioner of the Alaska Department of Natural Resources, Mr. Shively was a consultant on management issues, Alaska Native Land Claims, litigation and government relations.

Mr. Shively has been a regent for the University of Alaska. He has also served on the boards of the Anchorage Symphony, Democratic Leadership Council, Junior Achievement of Alaska, Inc. and the Alaskan Federation of Natives Legislative Committee as well as a number of other boards.

Mr. Shively is the author of a number of publications on the Alaska Native Claims Settlement Act and other Native and rural issues. He received the Denali Award in 1992 from the Alaska Federation of Natives for his contributions to the Native community.

Governor Knowles appointed Mr.Shivley to the Alaska Permanent Fund Corporation Board of Trustees in January 1999.

Mr. Shively resides in Anchorage, Alaska with his wife Alexandra and daughter Natasha. 


\section{Speaker Biography}

\section{Leo Schrider}

Leo Schrider is Senior Vice President of Technical Development for Belden \& Blake Corporation and has been with the northeast Independent for almost 20 years. Mr. Schrider is a Petroleum Engineer with 40 years of experience in oil and gas production.

Prior to joining Belden \& Blake he served as Assistant and Deputy Director of Morgantown Energy Technology Center. While with the DOE, he was the Program Manager for thee years at their In Situ Coal Gasification site in Laramie WY. He also worked for Shell Oil Company as a Petroleum Engineer in the Gulf Coast after graduating from the University of Pittsburgh in 1962. He has published more than 35 technical papers on oil and gas production. He has served as a member of the International Board of Directors of the Society of Petroleum Engineers.

In 1994, Mr. Schrider was elected to the Board of Directors of the Petroleum Technology Transfer Council and currently is the Chairman. 


\section{Petroleum Technology Transfer C ouncil}

\section{PTTC's Positive Impact on the \\ Upstream Oil \& Natural Gas Industry:}

\section{4 to Present}

Presented at Cosponsored Workshop

Opportunities in Alaska Coalbed Methane

Anchorage, Alaska

March 3, 2000 


\section{SO ME BAC KG RO UND O N BELDEN \& BLAKE}

Belden \& Blake's 1st commercial CBM venture in

15,000 acre project in Pennsylvania

$\gg 1000 \mathrm{ft}$ depth, multiple seams

$\gg 4.5 \mathrm{BCF}$ proved developed, $25 \mathrm{BCF}$ proved undeveloped with average of 210 MMCF per well

- No small project--we had a lot to learn

- We did learn--and made money in the process

- Currently extending project $(80,000$ acres leased) 


\section{WHERE $O$ UR LEARN IN G C URVE LED BELDEN \& BLAKE}

$75 \%$ of Belden \& Blake's newly discovered gas reserves now produced from unconventional sources

$\gg$ Coalbed methane in Pennsylvania

> Devonian shale production in West Virginia \&

Kentucky

$\gg$ Antrim Shale in Michigan

Newer technologies commonly employed $\gg$ geological high grading of development prospects >> drilling practices (including horizontal where applicable)

$\gg$ completion/stimulation techniques 


\section{O VERVIEW}

\section{Mission Statement:}

"PTTC benefits the nation by helping U.S. independent oil and natural gas producers make timely, informed technology decisions." 


\section{CO RE SERVIC ES}

TECHNOLOGY CONNECTIONS

PTTC helps producers make technology decisions through its 3 core services:

1) Problem Identification

2) Education

3) Connections 


\section{O RE SERVIC ES - PRO BLEM IDEN TIFIC ATIO N}

PTTC helps identify and clarify producers' problems

PTTC makes independents aware of technology opportunities

- PTTC learned that it must be responsive to industry's interests and needs

PTTC conducts ongoing problem identification through surveys and informal outreach 


\section{CO RE SERVIC ES - EDUCATIO N}

- PTTC educates independent oil and gas producers about technology solution options

- PTTC activities have a unique, concise format that the E\&P industry recognizes and values

〉 Presented from the operators' perspective 〉 Bottom-line results (technical and economic)

$\gg$ Sharing experiences - producers learn from each other as well as technical experts 


\section{CO RE SERVIC ES - CONNEC TIO NS}

\section{PTTC disseminates information through:}

Low-cost workshops providing real world solutions to specific needs

- Regional resource centers with referral assistance (mostly virtual operations)

Technical reports, newsletters, and databases

- Network of 11 websites (national plus 10 regions) 


\section{N ATIO N ALLY-O RG AN IZED}

\section{National Tech Transfer}

PTTC Network News (about 7,000 readers wl $75 \%$ from E\&P industry)

Solutions From the Field (workshop abstracts)

Petroleum Technology Digest wl World Oil (to over 10,000 producers in North America)

- Award-winning website (www.pttc.org)

E\&P Software Sampler on CD-ROM 


\section{REG IO N ALLY-FO C USED}

TECHNOLOGY CONNECTIONS

Petroleum Technology Transfer Council.

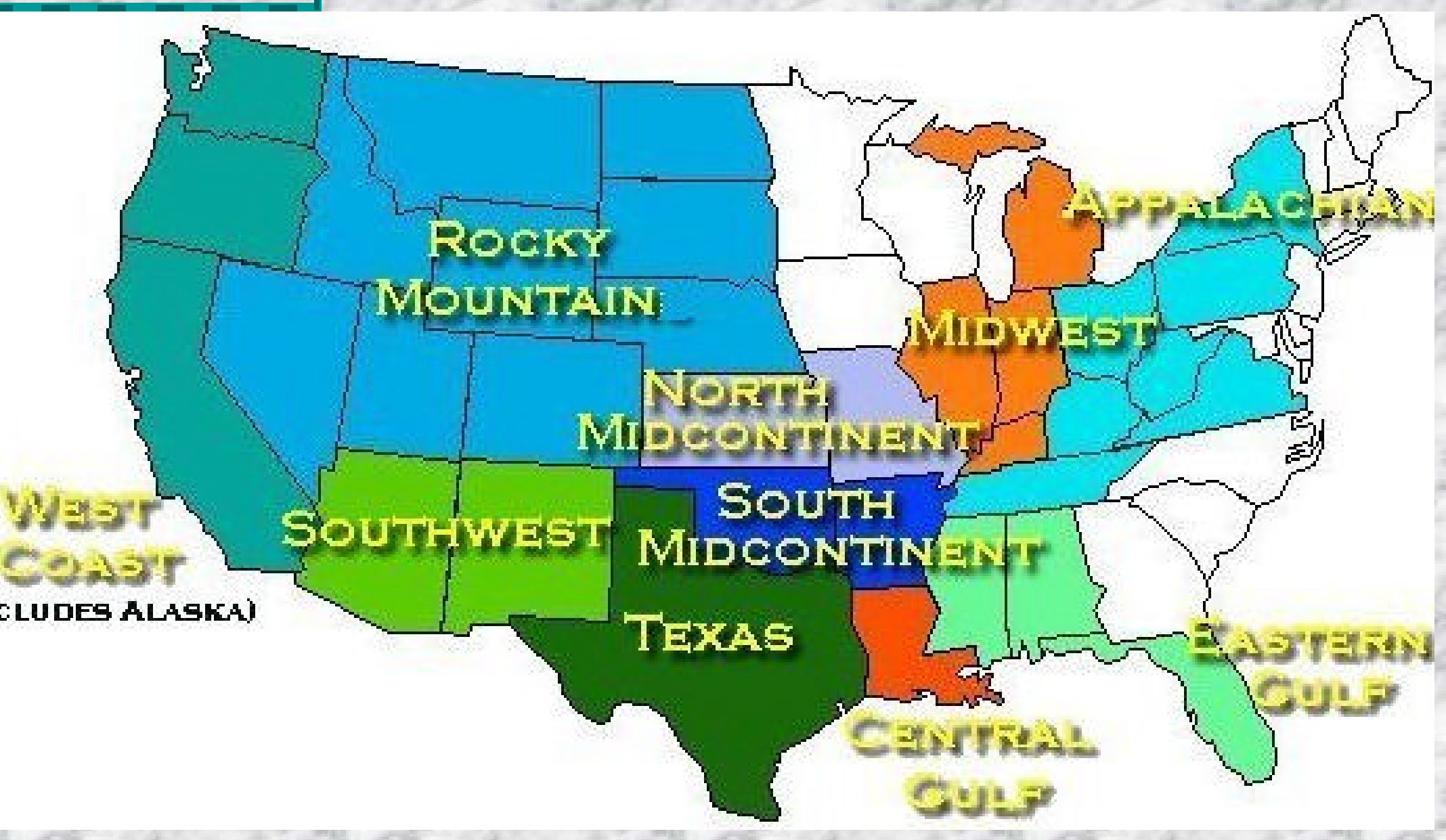

IMCLUDES ALASKA) 


\section{REG IO N ALLY-FO C USED}

\section{Newsletters}

Regional newsletters or columns in publications of producer groups (Total circulation of 19,000)

Technical content, calendar, news, etc.

\section{Websites}

- Over 70,000 user sessions/mo. (all 10 regions)

Traffic grows with added content - including case studies, databases, and links 


\section{REG IO N ALLY-FO C USED}

TECHNOLogy CONNECTIONS

\section{No. of \% from Contacts Workshops Attendance Industry (no.lyr.)}

FY95

FY96

FY97

FY98

FY99
18

46

62

100

128
1,117

3,801

3,176

4,429

5,948
75

83

85

73

83
3,000 *

4,000 *

5,482

10,241

10,555

* Estimated 


\section{REG IO N ALLY-FO C USED}

Measures of Regional Success

Activity levels

$\gg$ One-third more workshops in FY99

〉 Daily contacts averaging 4 per region

Attendees see value--coming back repeatedly

Significant $\%$ are applying technology 


\section{BE PART O F THE SUCCESS}

Tell PTTC what Alaskan independents need

Participate in West Coast regional activities

Call Iraj Ershaghi (213-740-0321) to see how you can become a part of PTTC in Alaska

Today's workshop kicks off new PTTC outreach 


\section{Contact the PTTC Regional Resource Center Nearest You:}

\section{Appalachian Region}

Director: Doug Patchen, West Virginia

University, 304-293-2867, ext. 5414

www. karl. nrcce. wvu. edu

\section{Central Gulf Region}

Director: Bob Baumann, Louisiana State

University, 225-388-I 804

www. em-g. Isu. edu/pttc_cgr. $h$ tml

\section{Eastern Gulf Region}

Director: Ernest Mancini, University of

Alabama, 2053484319

http://egrpttc. geo. ua. edu

\section{Midwest Region}

Director: David Morse, Illinois State

Geological Survey, 217-244-5527

http://pttc. isgs. uiuc. edu

\section{North Midcontinent Region}

Director: Rodney Reynolds, Kansas

University Energy Research Center,

785-864-7398

www. kgs. ukans. eduERC/pttcHome. html

\section{Rocky Mountain Region}

Director: Roger Slatt, Colorado School of

Mines, 303-273-3822

www. mines. edu/research/PTTC

\section{South Midcontinent Region}

Director: Charles Mankin, Oklahoma

Geological Survey, 405-325-3031

www.ou.edu/special/ogs-pttc/pttchome. htm

\section{Southwest Region}

Director: Robert Lee, Petroleum Recovery

Research Center, 505-835-5408

http://octane. nmt. edu/sw-pttc/PTTCstart. asp

\section{Texas Region}

Director: Scott Tinker, Bureau of Economic Geology, University of Texas at Austin, 512-471-0209

www. energyconnect. com/pttc

\section{West Coast Region}

Director: Iraj Ershaghi, University of

Southern California, 213-740-8076

www.USC. edu/dept/peteng/pttc.html

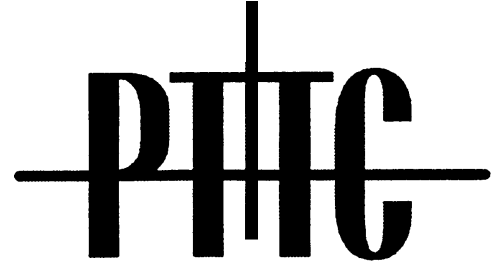

\section{TECHNOLOGY CONNECTIONS}

For U.S. independent oil and natural gas producers, obtaining access to cost-effective exploration and production (E\&P) technologies is an act of survival. Often facing razor-thin profit margins, independents need field-tested and proven, cost-effective solutions to their E\&P problems. The Petroleum Technology Transfer Council (PTTC) enables independents to make timely, informed technology decisions-through targeted connections to potential solutions-in its five program lines:

- Exploration

- Drilling and completion

- Operations and production

- Reservoir and development

- Environmental

PTTC functions as the "Bridge to Solutions" for independents by helping them identify and clarify problems, by educating them about potential solutions and opportunities, and by connecting them with technology providers. In each of these areas, PTTC disseminates information and makes connections via a network of regional resource centers at universities and state geological surveys with strong oil and gas expertise. (See organizations listed at the left.)

Some of PTTC's most important products and services include:

- Low-cost regional workshops that provide real-world solutions targeted to specific problems and opportunities

- Regional resource centers with technical referral assistance and demonstrations of exploration and production software

- An award-winning national website linked to PTTC's 10 regional websites and other electronic resources

- Timely publications and information products including newsletters, technical reports, databases, software samplers and case studies

PTTC is a national not-for-profit organization established in 1994 by the Independent Petroleum Association of America in conjunction with other industry groups. It is primarily funded by the U.S. Department of Energy, Office of Fossil Energy, through a grant from the National Petroleum Technology Office and National Energy Technology Lab. Other support is provided by several state governments, universities, state geological surveys, and industry. As a tax-exempt corporation under IRS Section 501(c)(3), contributions to PTTC are tax-deductible.

Petroleum Technology Transfer Council 1101 16th Street, N.W., Suite 1-C Washington, DC 20036-4803

Phone 202-785-2225 Fax 202-785-2240 Call toll-free 1-888-THE-PTTC E-mail: hq@pttc.org Website: wwww.pttc.org 


\section{Program Review}

\section{Jim G. Clough}

Alaska Division of Geological \& Geophysical Surveys 


\section{Speaker Biography}

\section{Jim G. Clough}

B.A. in Geology, College of Wooster, 1975

M.Sc. in Geology, University of Alaska Fairbanks, 1981

Currently a doctoral candidate in Geology, University of Alaska Fairbanks

Jim Clough has been involved in the study of Alaska geology since 1975. In the late 1970's, while working on his masters degree, he was employed by several exploration companies seeking mineral propects in Alaska's interior. In 1981 Jim began working as a geologist for the State of Alaska, Division of Geological Geophysical Surveys where he is currently the Chief of the Energy Resources Section. Jim's specialties include coal resources, basin analysis, and carbonate sedimentology and sequence stratigraphy. Jim also has a special interest in Alaska Native languages and received a B.A. in Yup'ik Eskimo from the University of Alaska Fairbanks in 1986. 


\title{
Technical Program
}

\section{Moderator}

\author{
Dr. Iraj Ershaghi
}

Director, West Coast PTTC 


\section{Speaker Biography}

\section{Professor Iraj Ershaghi}

Dr. Iraj Ershaghi is the Omar B. Milligan Professor and the Director of the Petroleum Engineering Program at USC's Chemical Engineering Department. He is also the Director of the West Coast PTTC. He received his Ph.D. in petroleum engineering from USC in 1972. He has numerous publications in the areas of formation evaluation, enhanced oil recovery, neural network, geostatistical methods and production optimization. He is the recipient of SPE's 1982 Distinguished Faculty Award as well as the 1996 SPE's Distinguished Member Award. He is a member of the New York Academy of Sciences. 


\section{Overview of Coalbed Methane Resources In Alaska}




\section{The Potential for Developing Coalbed Methane Exploration Fairways and Sweet Spots along the North Slope of Alaska}

Roger Tyler Arc Group LLC

Andrew Scott Texas Bureau of Economic Geology

Jim G. Clough Alaska Division of Geological \& Geophysical Surveys 


\section{Speaker Biography}

\section{Andrew R. Scott}

Andrew R. Scott is a Research Associate at the Bureau of Economic Geology, The University of Texas at Austin where he has been active in coalbed methane research for more than 10 years.

His current coalbed methane research interests include the application of integrated hydrogeologic exploration techniques and Microbially Enhanced Coalbed Methane (MECoM pronunced "mee-com").

Andrew has published numerous coalbed methane research papers and abstracts, taught short courses nationally and internationally, and is fortunate to have received several best paper awards for his research efforts.

He recently served as PTTC Director for the Texas Regions as well as Program Director for Domestic Energy Research and Acting Program Director for International Energy Research projects at the Bureau.

Andrew is currently serving as Vice-President of the Energy Minerals Division of AAPG. 


\section{The Potential for Developing Coalbed Methane Exploration Fairways and Sweet Spots along the North Slope of Alaska}

As part of a cooperative agreement between the Bureau of Economic Geology and the Alaskan Geological and Geophysical Surveys, which evaluated the potential for coalbed methane resource development in rural Alaska, the coalbed methane potential along the North Slope has been identified. Application of the integrated geologic and hydrologic producibility model strongly suggests the presence of coal gas in the subsurface. Along the North Slope high coalbed methane production will require dynamic ground-water flow through coals of higher thermal maturity (rank) and, possibly, high gas content orthogonally toward flow barriers (fault systems, facies changes, permafrost contrasts, and/or discharge areas) accompanied by conventional trapping of migrated thermogenic and solution gases along those barriers.

In the Colville Basin, along the western North Slope, conventional trapping in areas of updip migration and upward vertical flow potential of thermogenic gases will play an important role in coalbed methane production. Because the western North Slope contains low rank coals at surface localities (subbituminous), there is a need for additional sources of gas beyond that initially sorbed on the coal surface to achieve significant production. Those additional sources of gas are conventionally trapped, migrated thermogenic and solution gases. Therefore, based on the coalbed methane exploration and development model, the exploration fairway of the North Slope should be those areas, where outcrop and subsurface coals are in hydraulic communication for consequent advective gathering and migration of gas, and subsequent resorption and conventional trapping, which promote fully gas-saturated coals and high production. Conventional trapping of migrated coal gases beneath the permafrost may be a critical component in coalbed methane producibility. Based on these critical criteria, a fairway extending from the rural villages of Waimight to Atqasuk and 30 miles south of these villages is a prime target for a coalbed methane exploration. 


\section{A Case Study on the "Pioneer Project"}

Dan Seamount

Unocal

Robert A. Downey

Ocean Energy 


\section{Speaker Biography}

\section{Robert A. Downey}

Robert Downey earned his bachelor degree in Petroleum Engineering in 1976 from Colorado School of Mines. Following graduation he worked for Amoco Production Company for 10 years. Mr. Downey founded Energy Ingenuity in 1986. He specializes in the field of coalbed methane and is currently providing consulting in petroleum engineering, geology, and economic analysis services through his company. He has been involved in CBM projects in several basins in the U.S. as well as overseas. His home is in Littleton, Colorado. 


\section{PIONEER COAL BED METHANE}

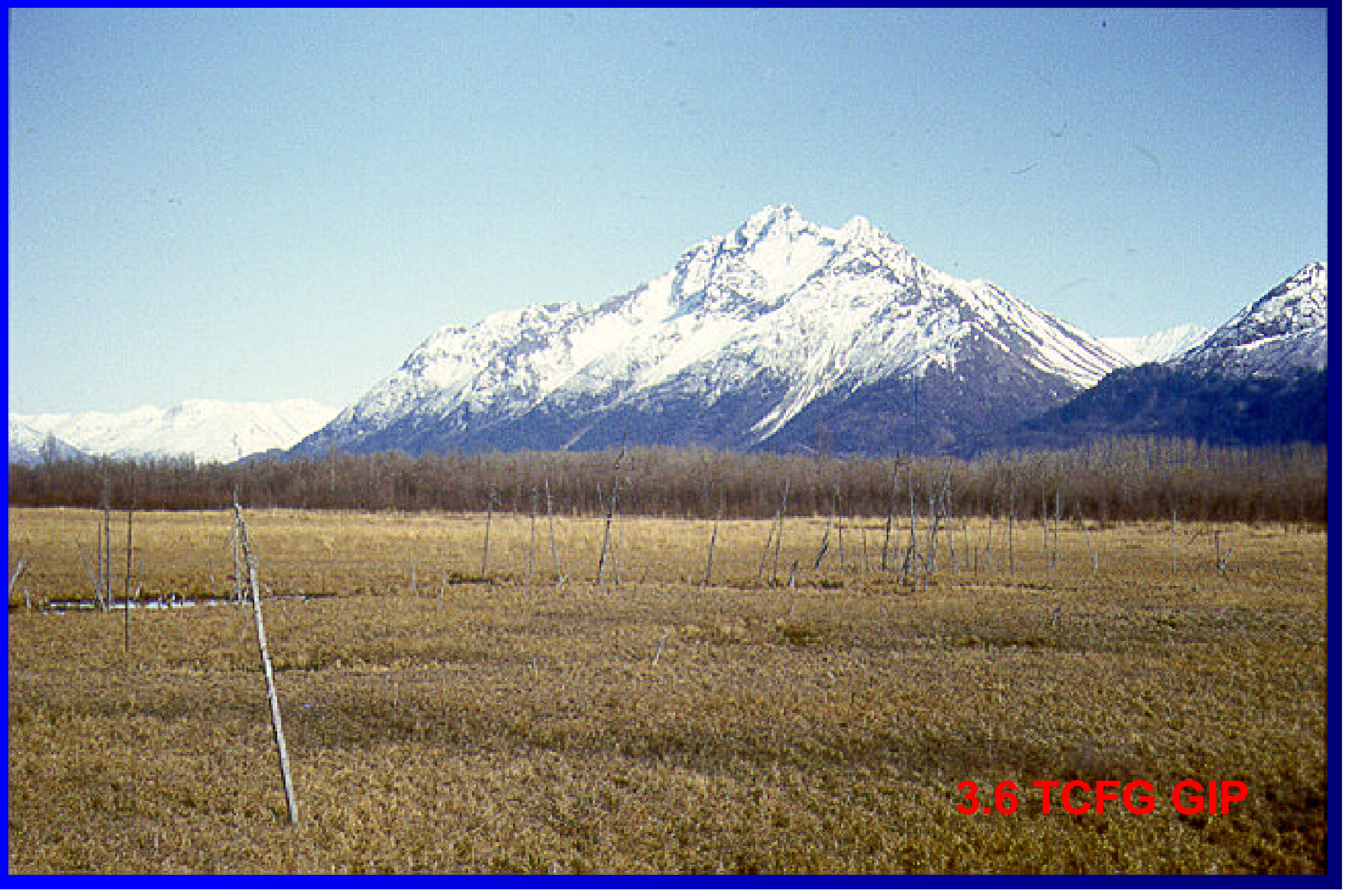




\section{Pioneer Unit Coalbed Methane Project}

- Opportunity Identified and Developed by Unocal

- Unocal Formed the Pioneer Unit as an Alaska State Unit

- Unocal has been in the Cook Inlet Area for 40 Years

- Ocean Acquired Seagull Energy, including the Enstar Alaska Gas Pipeline System, in late 1998

- Ocean has CBM Development Experience

- Ocean and Unocal Agreed to Jointly Develop the Coalbed Methane Resources in Pioneer Unit 


\section{Pioneer Prospect Coal Bed Methane}

Unconventional gas play proven in L48 and elsewhere

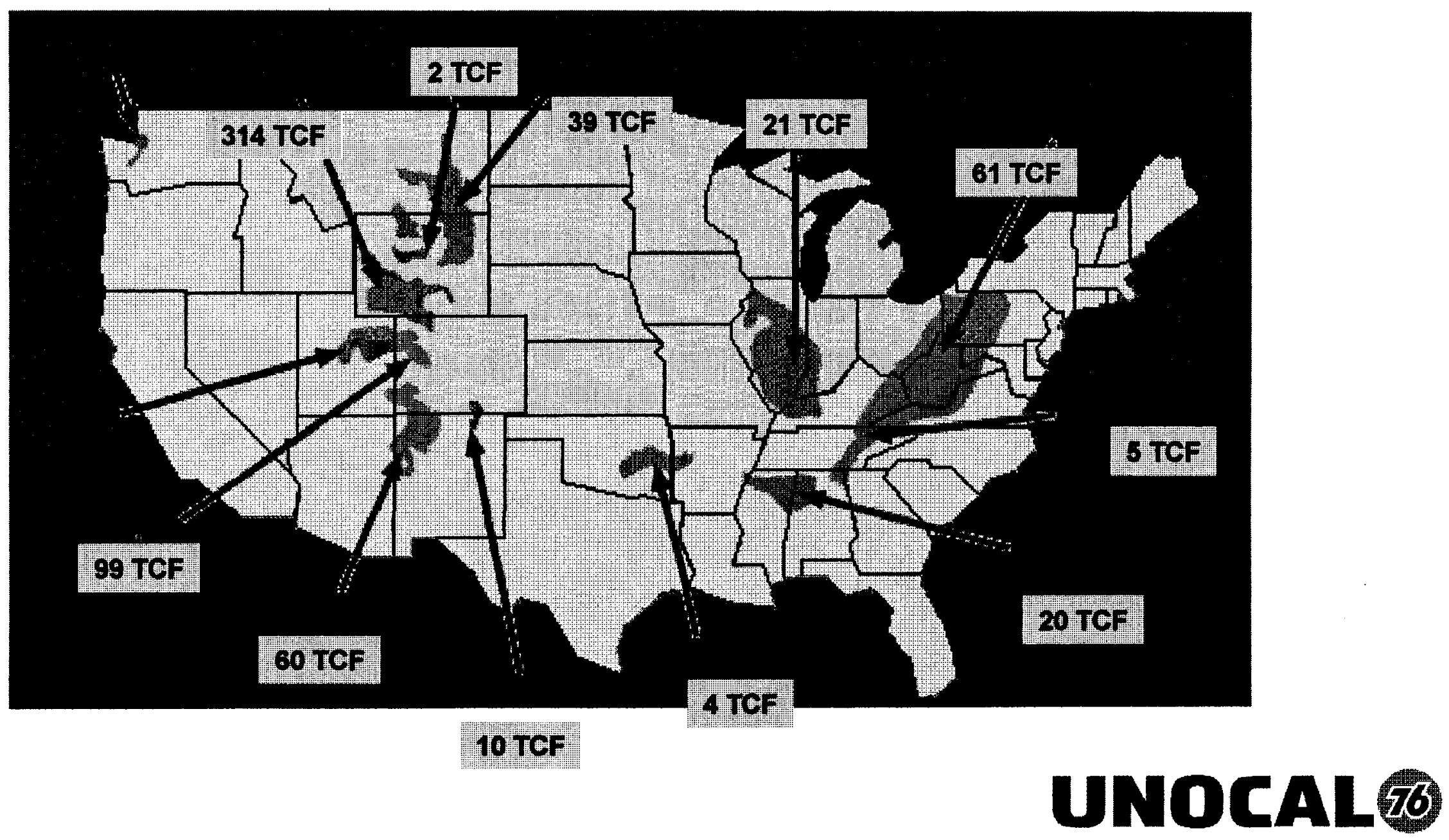




\section{Pioneer Prospect Coal Bed Methane}

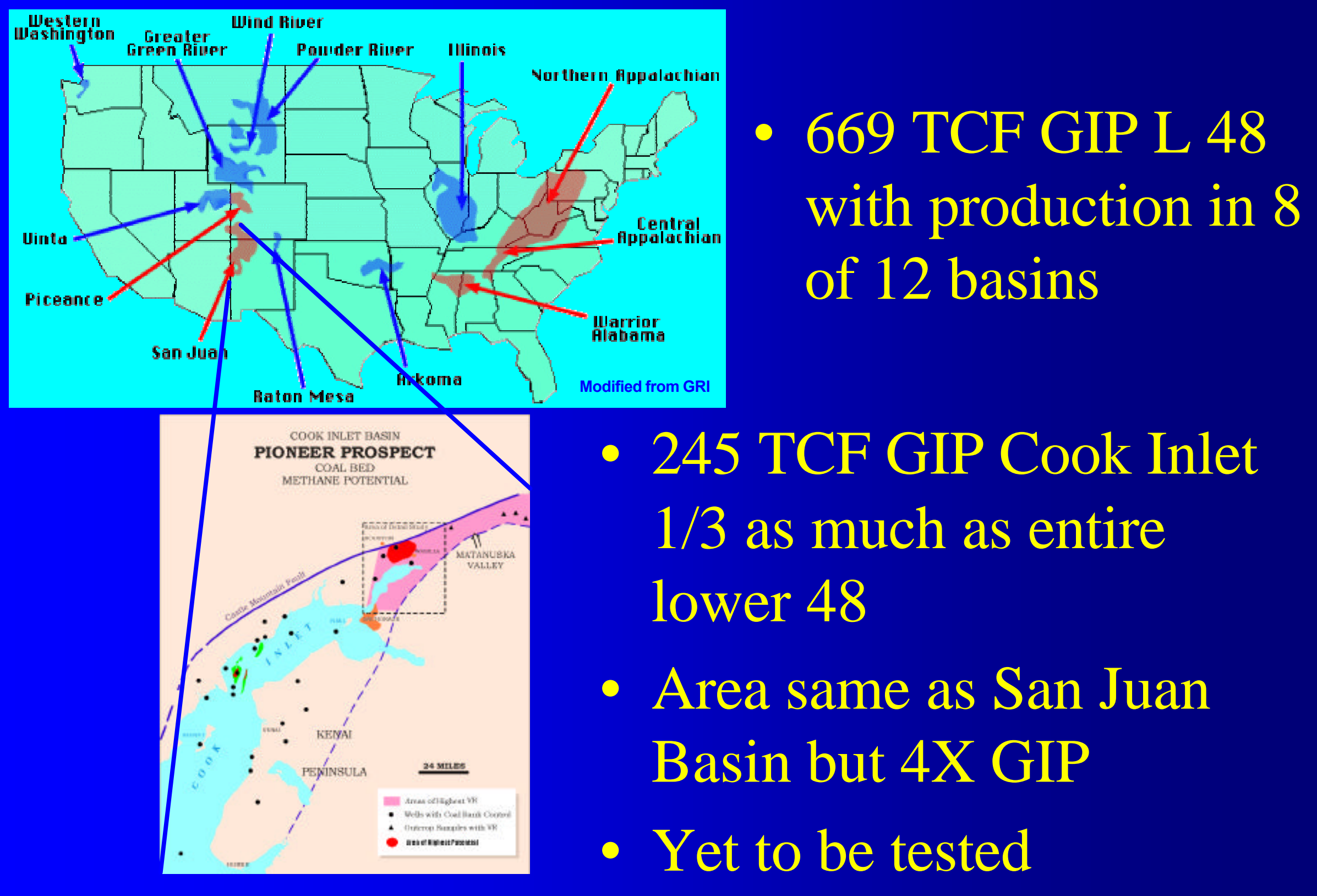




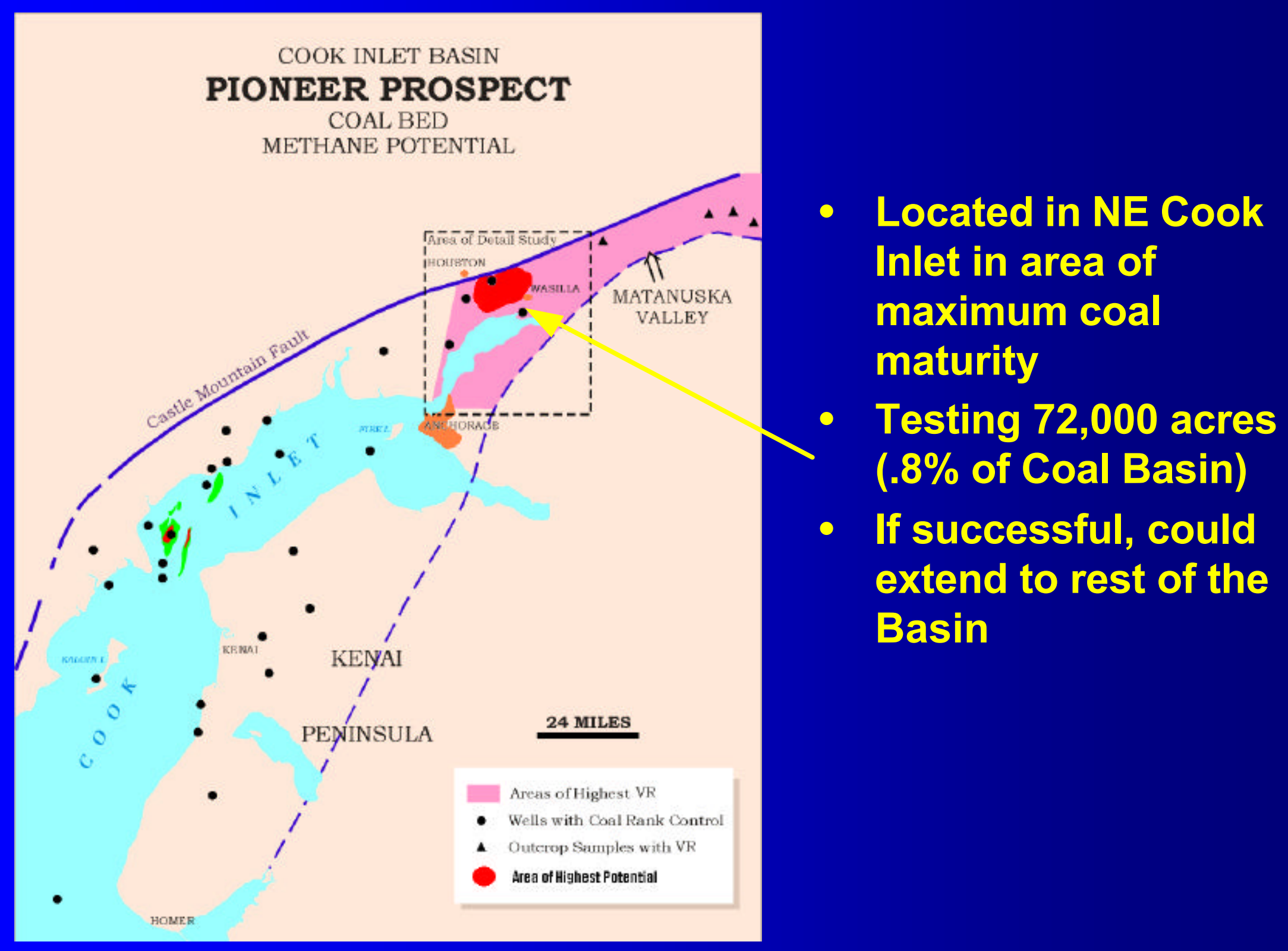


Pioneer Prospect Coal Bed Methane

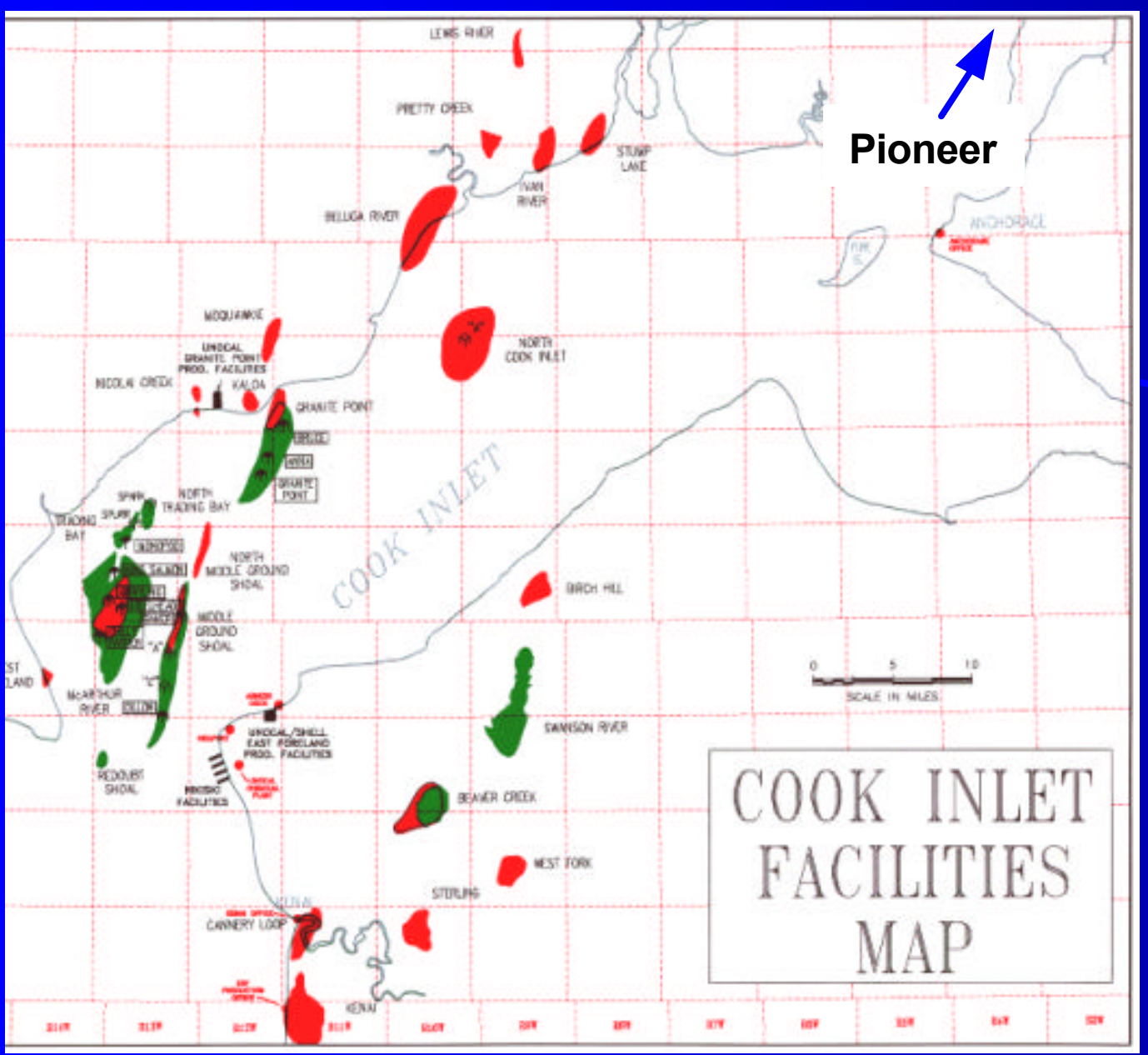

Coal is the source of 7.7 Tcf of Cook Inlet's 8.3 Tcf "conventional" gas 


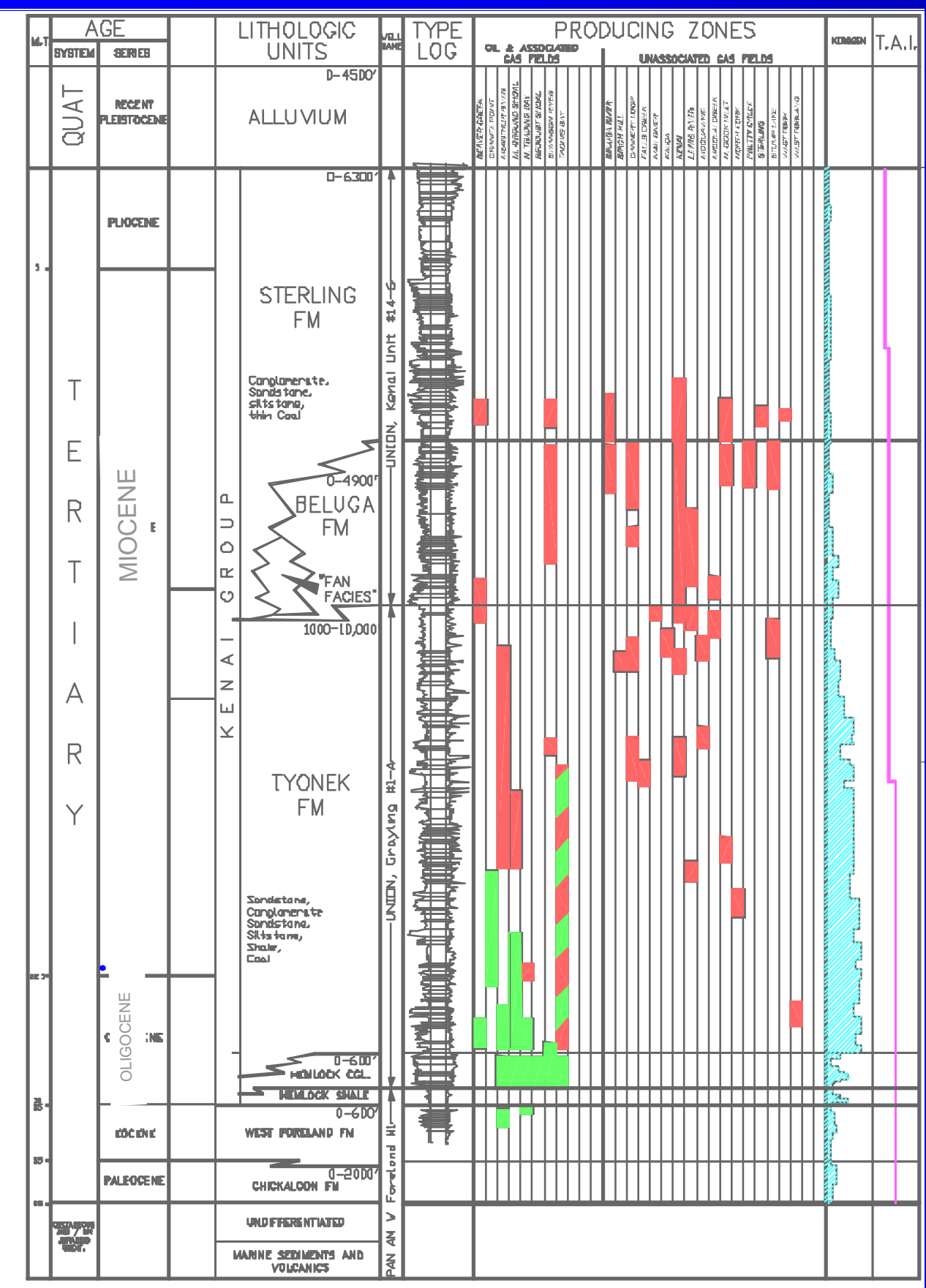

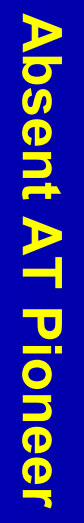

- Upper Tyonek and younger sediments have been eroded

- Lower Tyonek with higher coal maturity uplifted

COOK INLET STRATIGRAPHIC CHART 


\section{Cook Inlet Coalbed Methane}

- In the Cook Inlet area, it has been estimated that about $93 \%$ of the natural gas found to date - over 8 Trillion cubic feet - was generated by coal.

- The USGS recently estimated the total coalbed methane gas resources in the Cook Inlet to be 245 Trillion cubic feet. The total coalbed methane resources for the entire Lower 48 states is 695 Trillion cubic feet.

- Most of the coalbed methane resource in the Cook Inlet area is too deep to be economically viable to attempt to recover.

- The best area for the development of Cook Inlet coalbed methane is the area around Houston-Wasilla. In this area, thick coals appear to have much higher gas content and exist at reasonable depth. Also, proximity to the only gas pipeline in the Inlet will enable earlier, less costly production. 


\section{Pioneer CBM Key Attributes}

- Numerous, thick coalseams indicated at shallow depths

- State of Alaska AK-94 Well Stratigraphic Test Indicated Good Coal Gas Contents

- Available leasehold acreage

- Existing infrastructure

- Good accessibility to drilling locations

- Potential Production from Conventional sands 


\section{Depth to Ro $>.6 \%$}

Gas Content increased from

63 cu-ft/ton @sl to $24.5 \mathrm{cu}-\mathrm{ft} / \mathrm{t}$. @ - $745^{\prime}$ in DNR AK-94-1

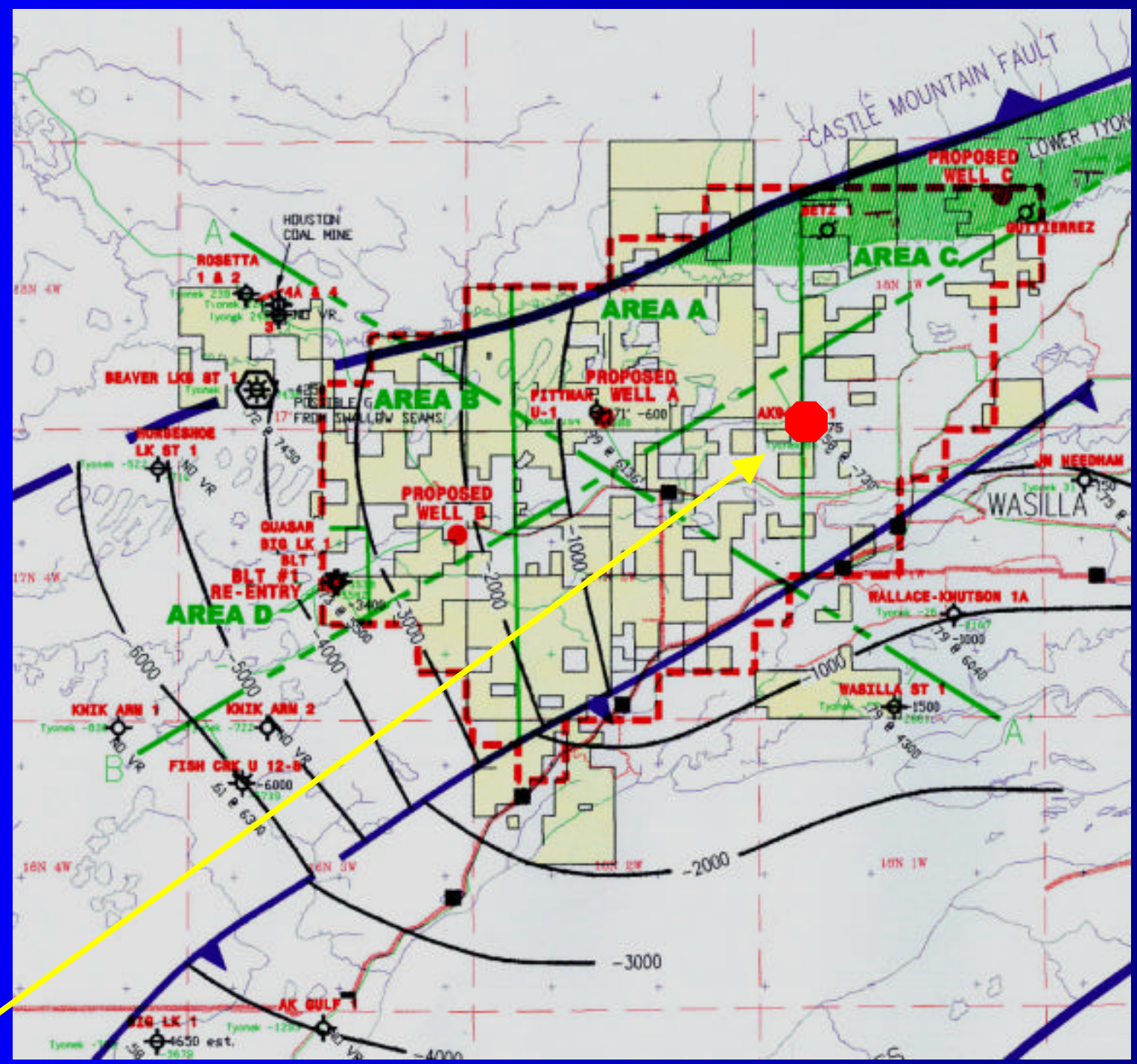




\section{Alaska DNR Core Hole AK-94-1}
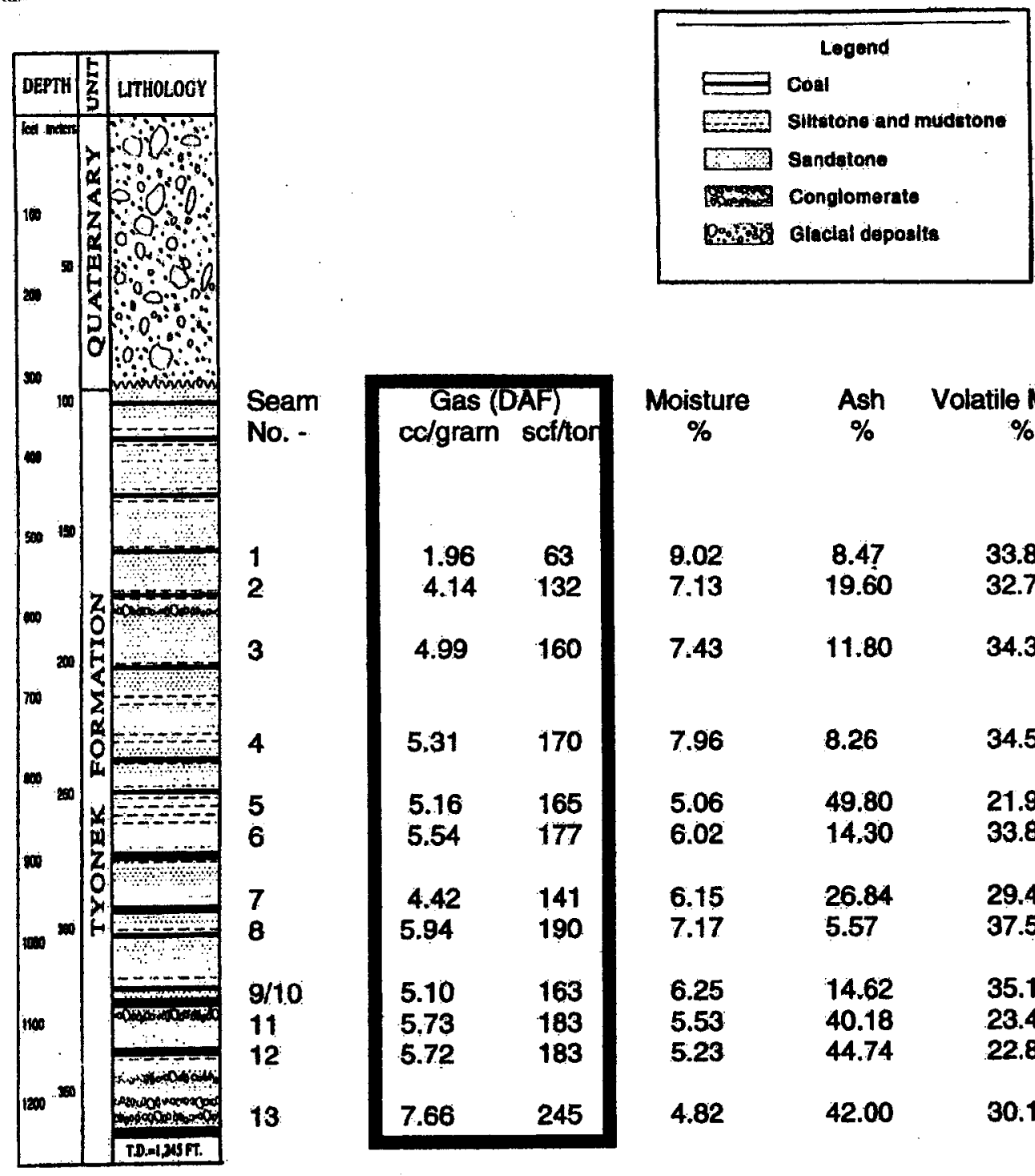

\begin{tabular}{|c|c|c|c|c|c|c|c|c|c|}
\hline $\begin{array}{l}\text { Seam } \\
\text { No. - }\end{array}$ & $\begin{array}{l}\text { Gas } \\
\text { co/grarr }\end{array}$ & Acf/tor & $\begin{array}{c}\text { Moisture } \\
\%\end{array}$ & $\begin{array}{l}\text { Ash } \\
\%\end{array}$ & $\begin{array}{c}\text { Volatile Matter } \\
\%\end{array}$ & $\begin{array}{c}\text { Fixed Carbon } \\
\%\end{array}$ & $\begin{array}{l}\text { Ro } \\
\%\end{array}$ & $\& 13 C$ & Cannister \#'s \\
\hline $\begin{array}{l}1 \\
2\end{array}$ & $\begin{array}{l}1.96 \\
4.14\end{array}$ & $\begin{array}{c}63 \\
132\end{array}$ & $\begin{array}{l}9.02 \\
7.13\end{array}$ & $\begin{array}{c}8.47 \\
19.60\end{array}$ & $\begin{array}{l}33.80 \\
32.78\end{array}$ & $\begin{array}{l}48.71 \\
40.49\end{array}$ & 0.48 & & $\begin{array}{l}1,2 \\
3,4\end{array}$ \\
\hline 3 & 4.99 & 160 & 7.43 & 11.80 & 34.34 & $46 / 43$ & & -48.9 & 5,6 \\
\hline 4 & 5.31 & 170 & 7.96 & 8.26 & 34.55 & 49.23 & 0.47 & & 7,8 \\
\hline $\begin{array}{l}5 \\
6\end{array}$ & $\begin{array}{l}5.16 \\
5.54\end{array}$ & $\begin{array}{l}165 \\
177\end{array}$ & $\begin{array}{l}5.06 \\
6.02\end{array}$ & $\begin{array}{l}49.80 \\
14,30\end{array}$ & $\begin{array}{l}21.93 \\
33.84\end{array}$ & $\begin{array}{l}23.21 \\
45.84\end{array}$ & 0.56 & $\begin{array}{l}-49.3 \\
-48.3\end{array}$ & $\stackrel{9}{11,12,13,14}$ \\
\hline $\begin{array}{l}7 \\
8\end{array}$ & $\begin{array}{l}4.42 \\
5.94\end{array}$ & $\begin{array}{l}141 \\
190\end{array}$ & $\begin{array}{l}6.15 \\
7.17\end{array}$ & $\begin{array}{l}26.84 \\
5.57\end{array}$ & $\begin{array}{l}29.47 \\
37.50\end{array}$ & $\begin{array}{l}37.54 \\
49.76\end{array}$ & 0.52 & -47.0 & $\begin{array}{l}15,16,17,18 \\
19\end{array}$ \\
\hline $\begin{array}{l}9 / 10 \\
11 \\
12\end{array}$ & $\begin{array}{l}5.10 \\
5.73 \\
5.72\end{array}$ & $\begin{array}{l}163 \\
183 \\
183\end{array}$ & $\begin{array}{l}6.25 \\
5.53 \\
5.23\end{array}$ & $\begin{array}{l}14.62 \\
40.18 \\
44.74\end{array}$ & $\begin{array}{l}35.18 \\
23.42 \\
22.85\end{array}$ & $\begin{array}{l}43.95 \\
30.87 \\
27.18\end{array}$ & 0.58 & -43.3 & $\begin{array}{l}20,21,22 \\
23,24,25,26 \\
27,28,29,30 \\
31,32,33\end{array}$ \\
\hline 13 & 7.66 & 245 & 4.82 & 42.00 & 30.15 & 23.03 & 0.58 & -44.0 & $\begin{array}{l}34,35,37 \\
36,38\end{array}$ \\
\hline
\end{tabular}

Figure 9. Coal analyses for AK-94CBM- 1. (Modified from Smith, 1995) 


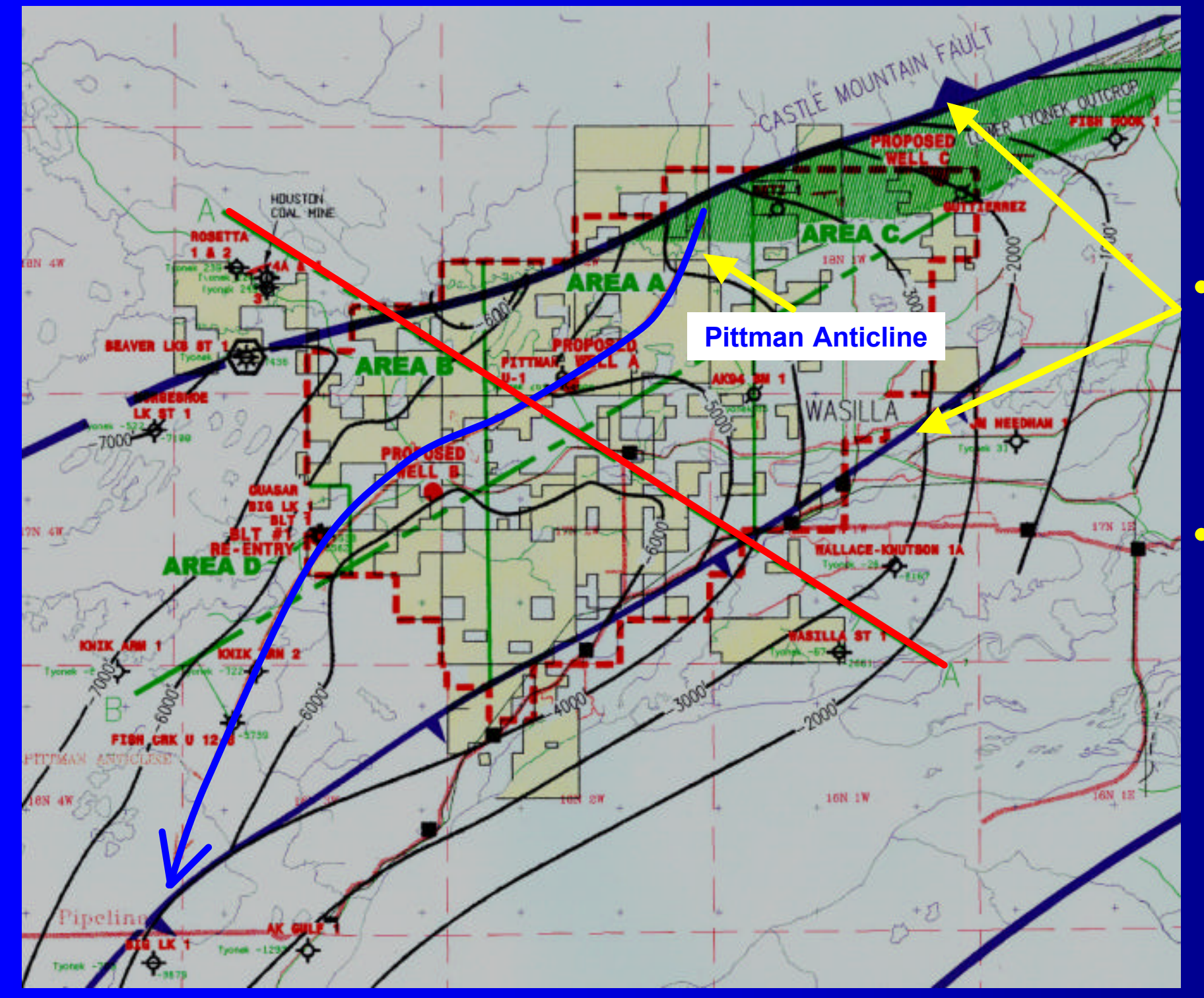

- Bounded by two active reverse faults

Pittman

Anticline bisects the unit

Base Tyonek Structure 


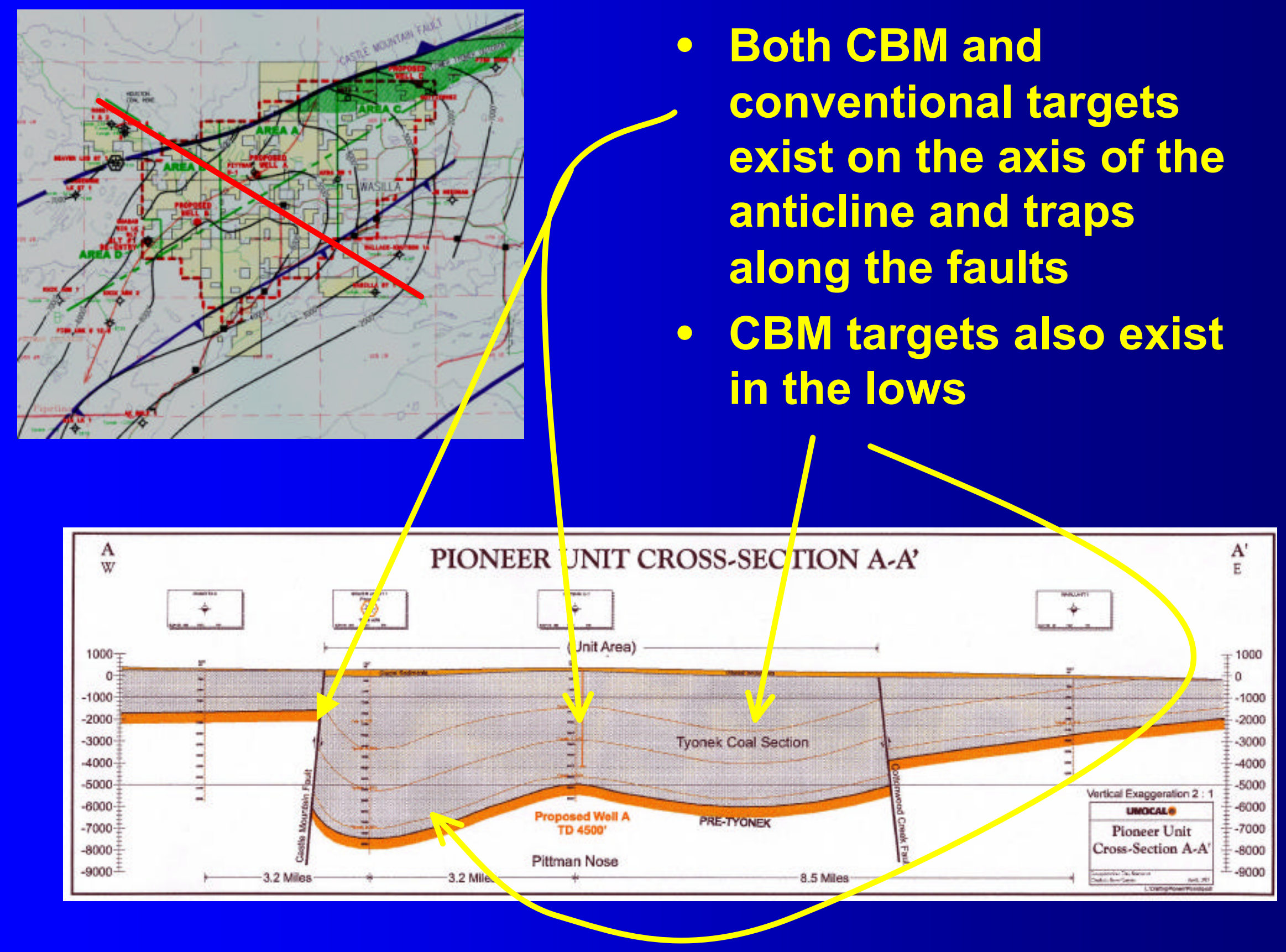




\section{Project Timing}

- Big Lake Well Re-Entry and Drilling of three Wells two producers and one saltwater disposal well - in small area near Vine Road were completed in 1999.

- Additional wells in this Plan of Operations may be considered based upon technical data obtained and well test information 


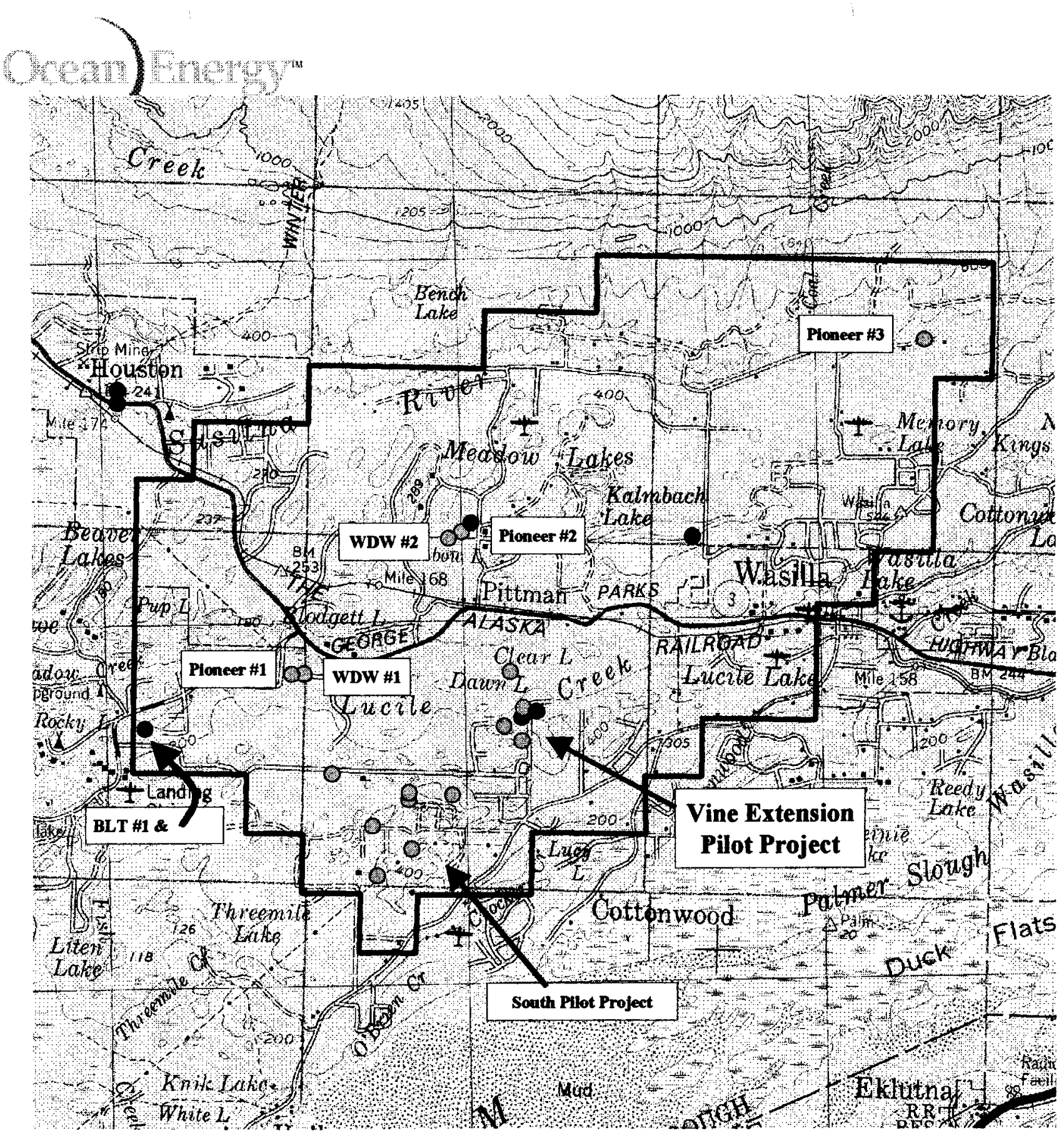

\section{Geography \&. Well Locations}

- Potential Future CBM

- CBM test Well Location, 1999

- Class II Waste Disposal Well Location, 1999 


\section{Coalbed Methane Drilling Rig Black Warrior Basin, Alabama}

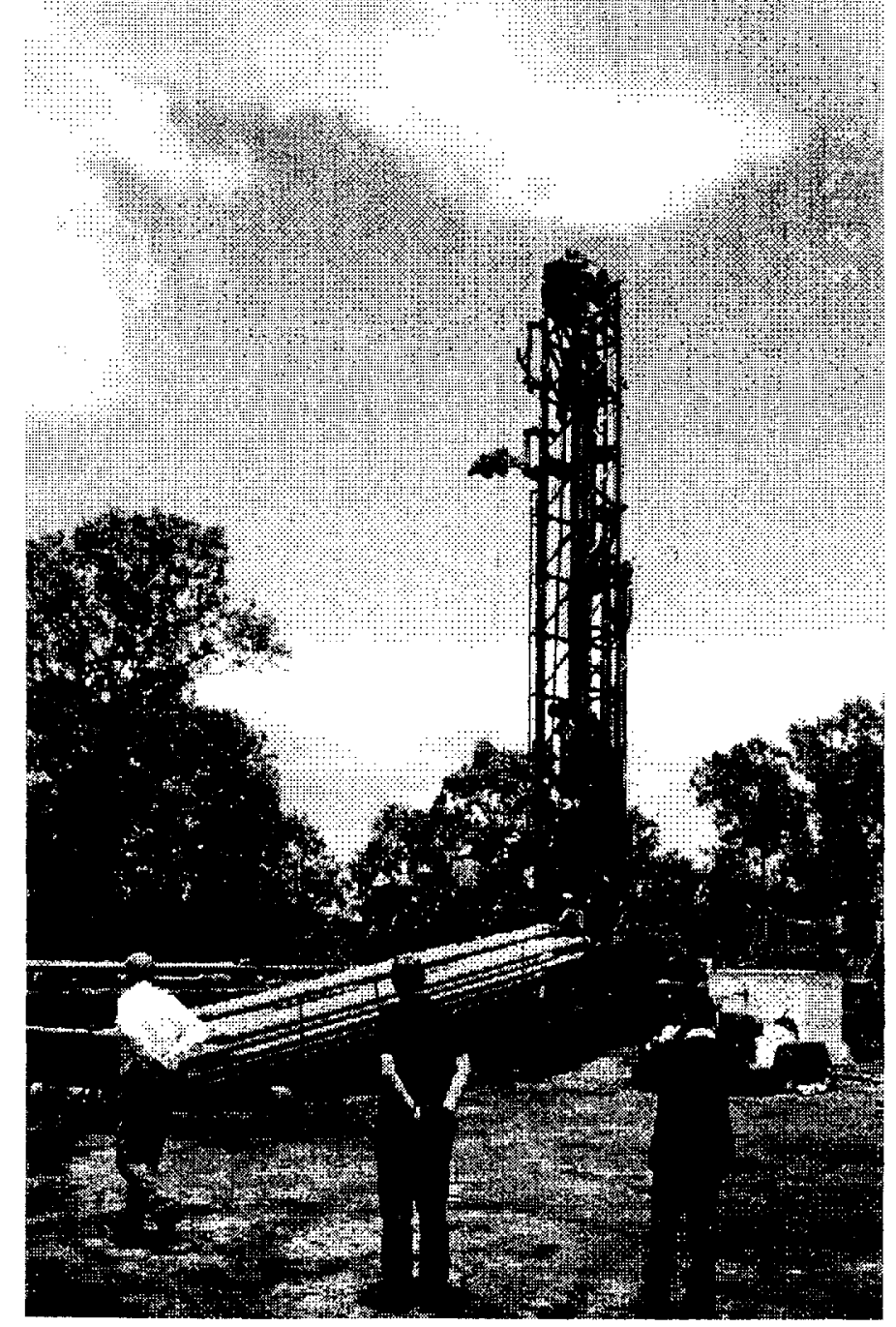




\section{Coalbed Methane Well Location Black Warrior Basin, Alabama}

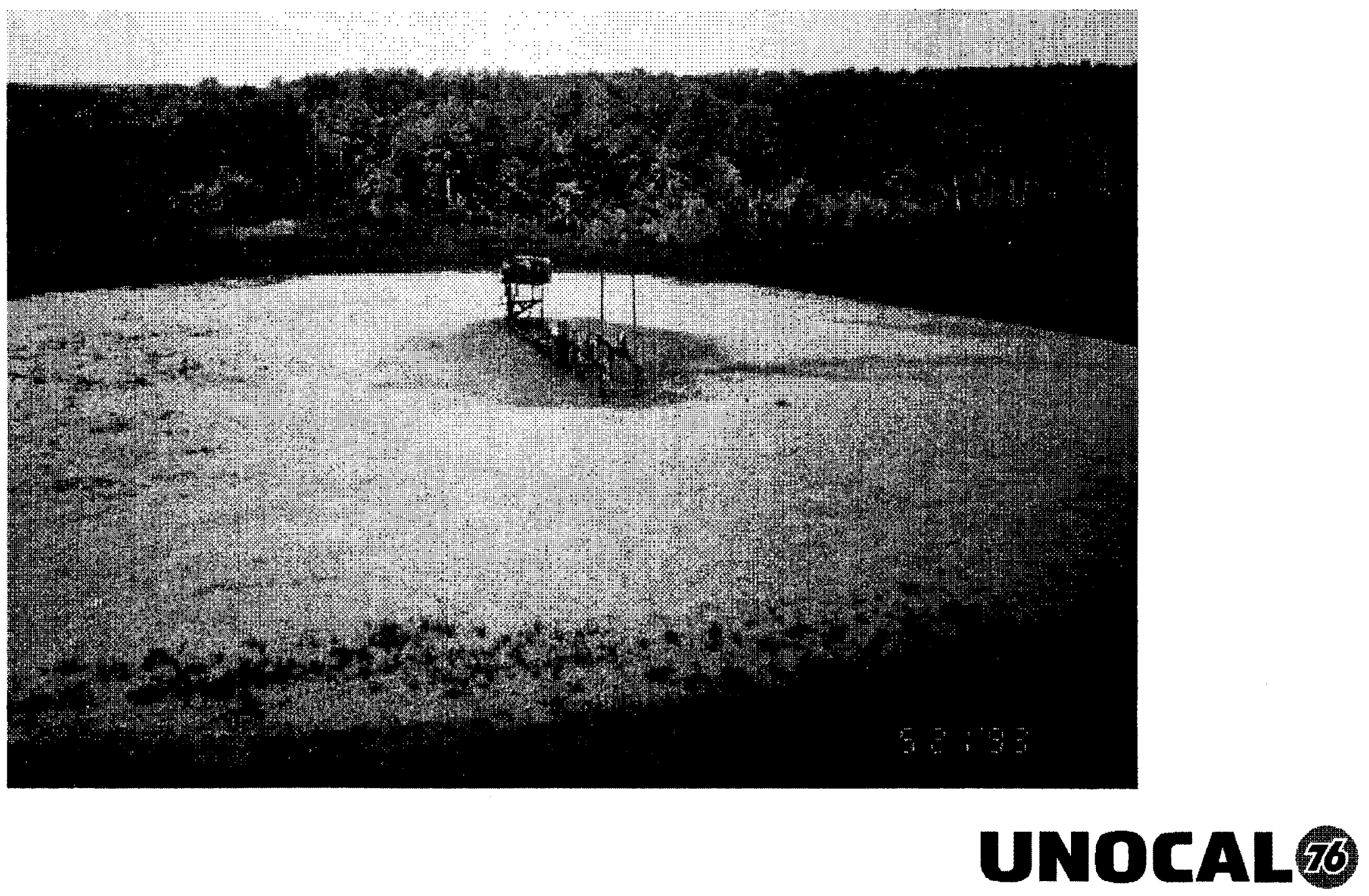




\section{Typical Coalbed Methane Well Black Warrior Basin, Alabama}

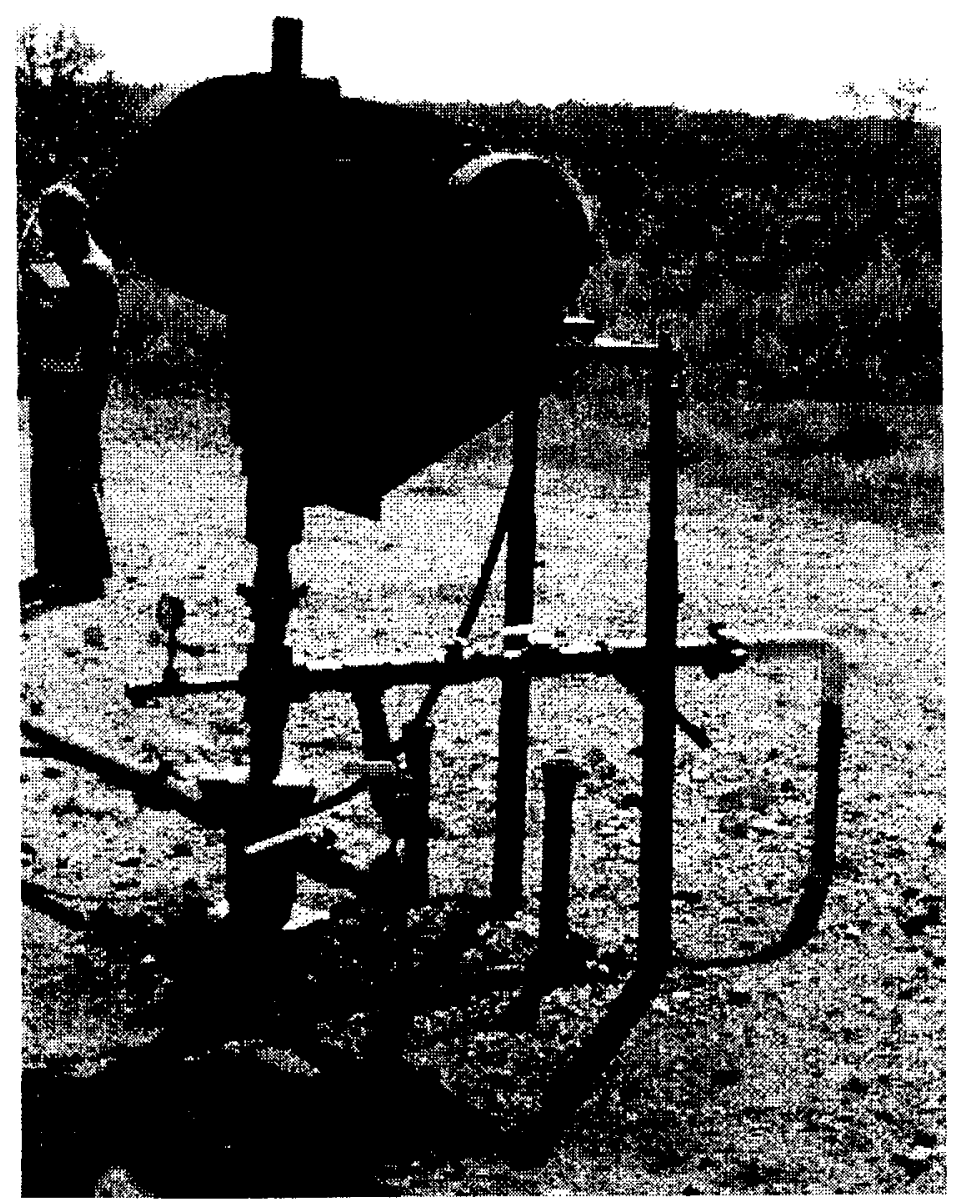




\section{Cutaway View of A Progressive Cavity Downhole Pump}

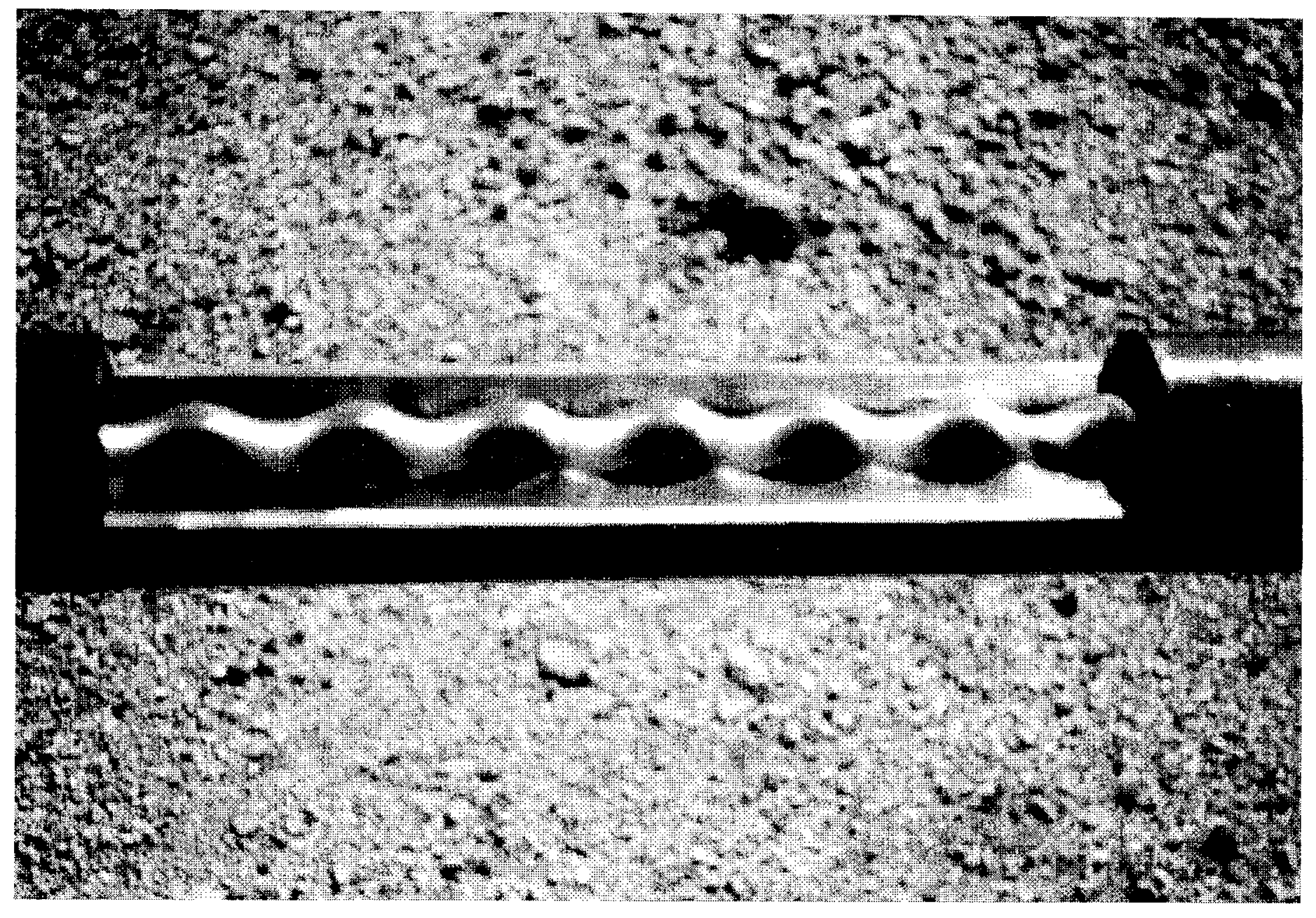




\section{CBM Drilling Rig Powder River Basin, Wyoming}

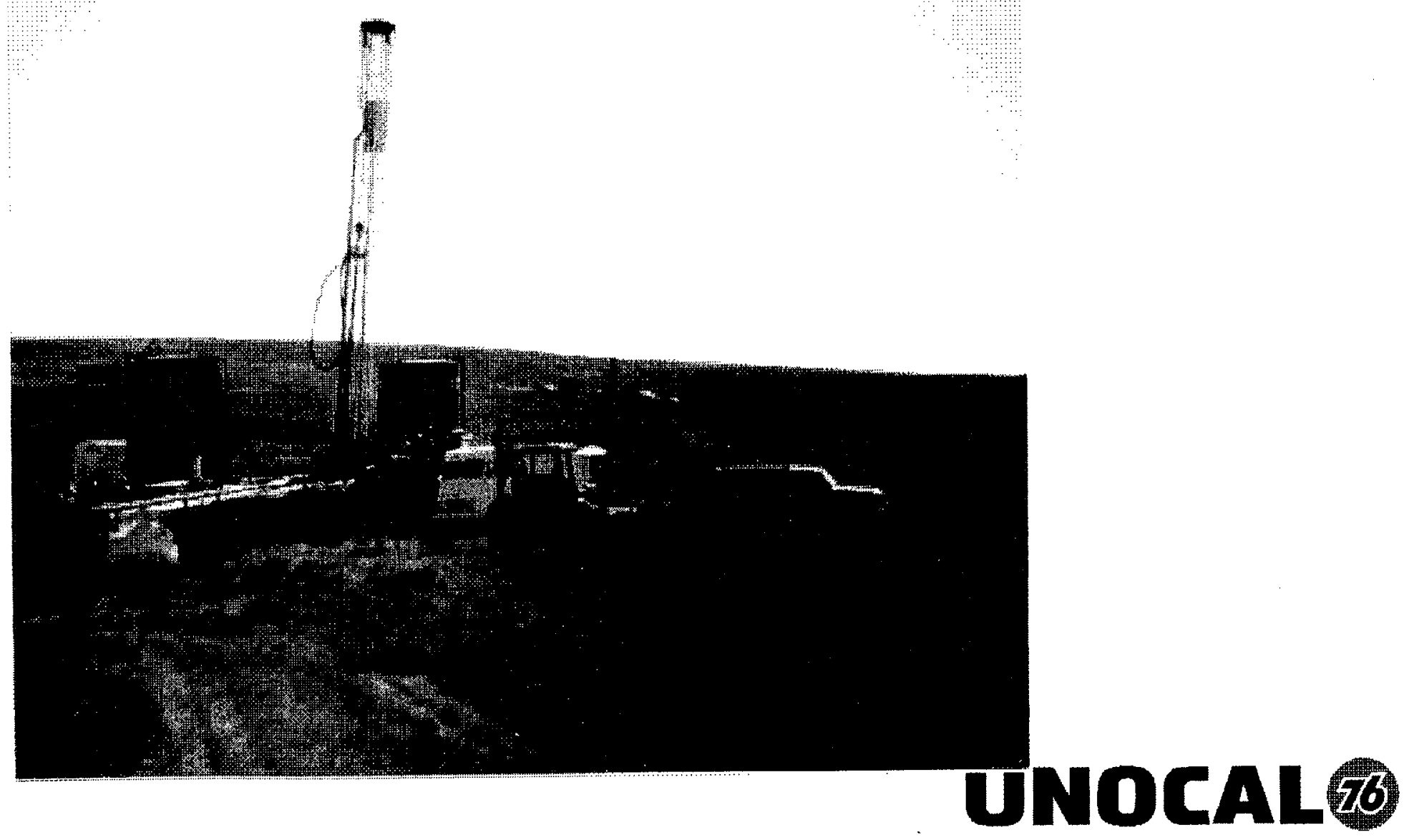




\section{CBM Drilling Rig, Powder River Basin, Wyoming}

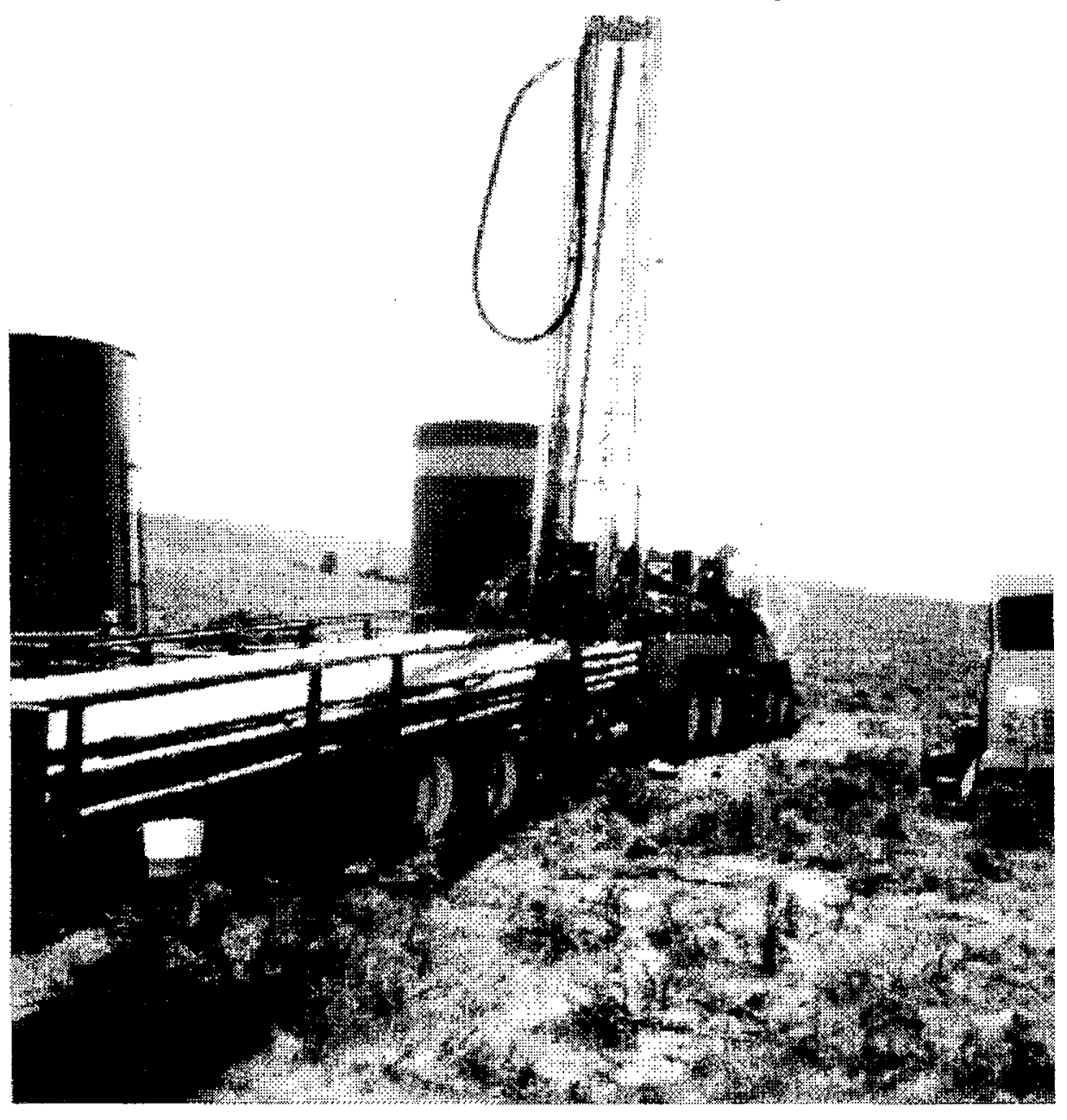




\section{CBM Producing Well, Powder River Basin, Wyoming}

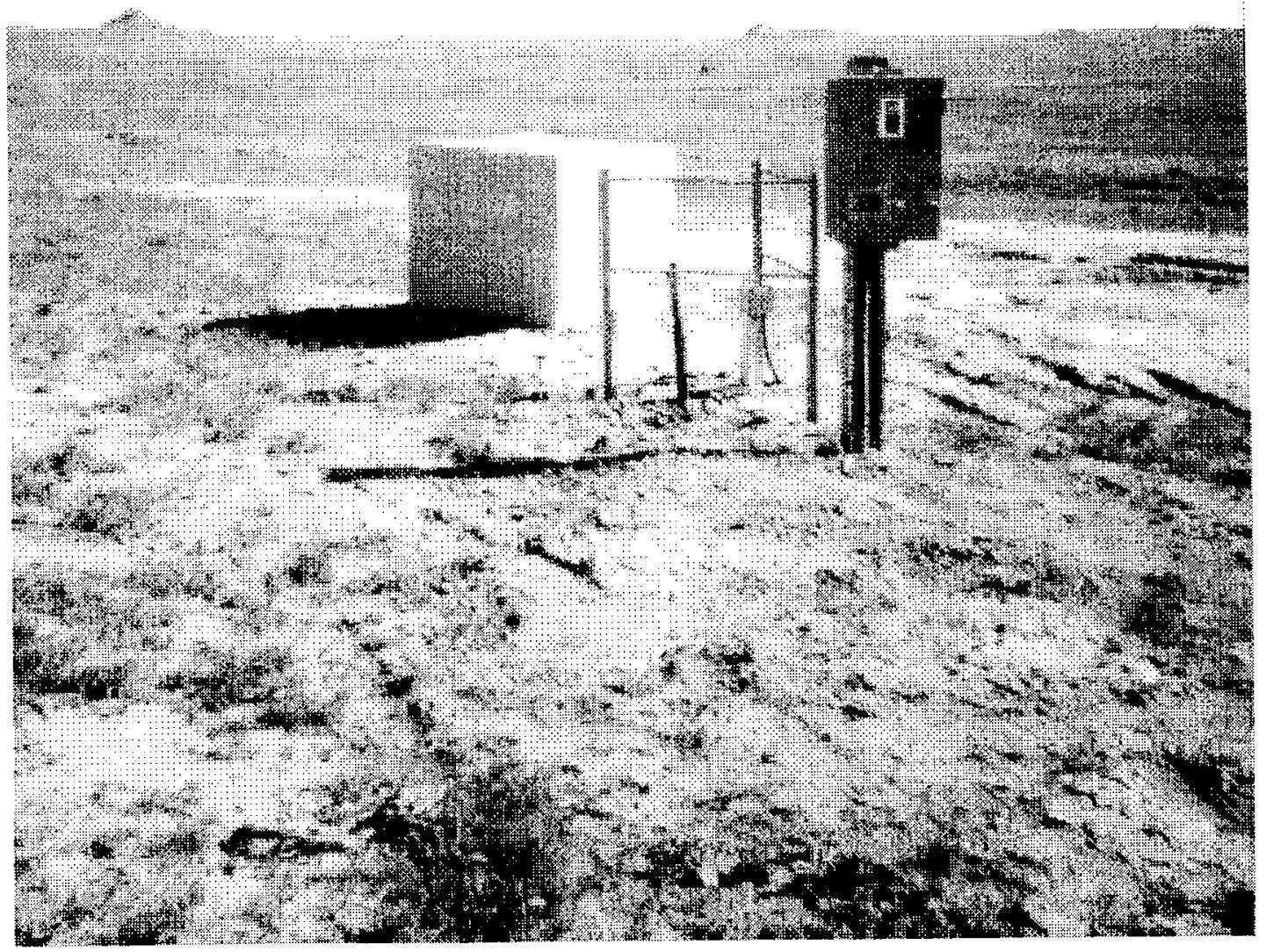




\section{CBM Wellhead and Opened Weather Enclosure, Powder River Basin, Wyoming}

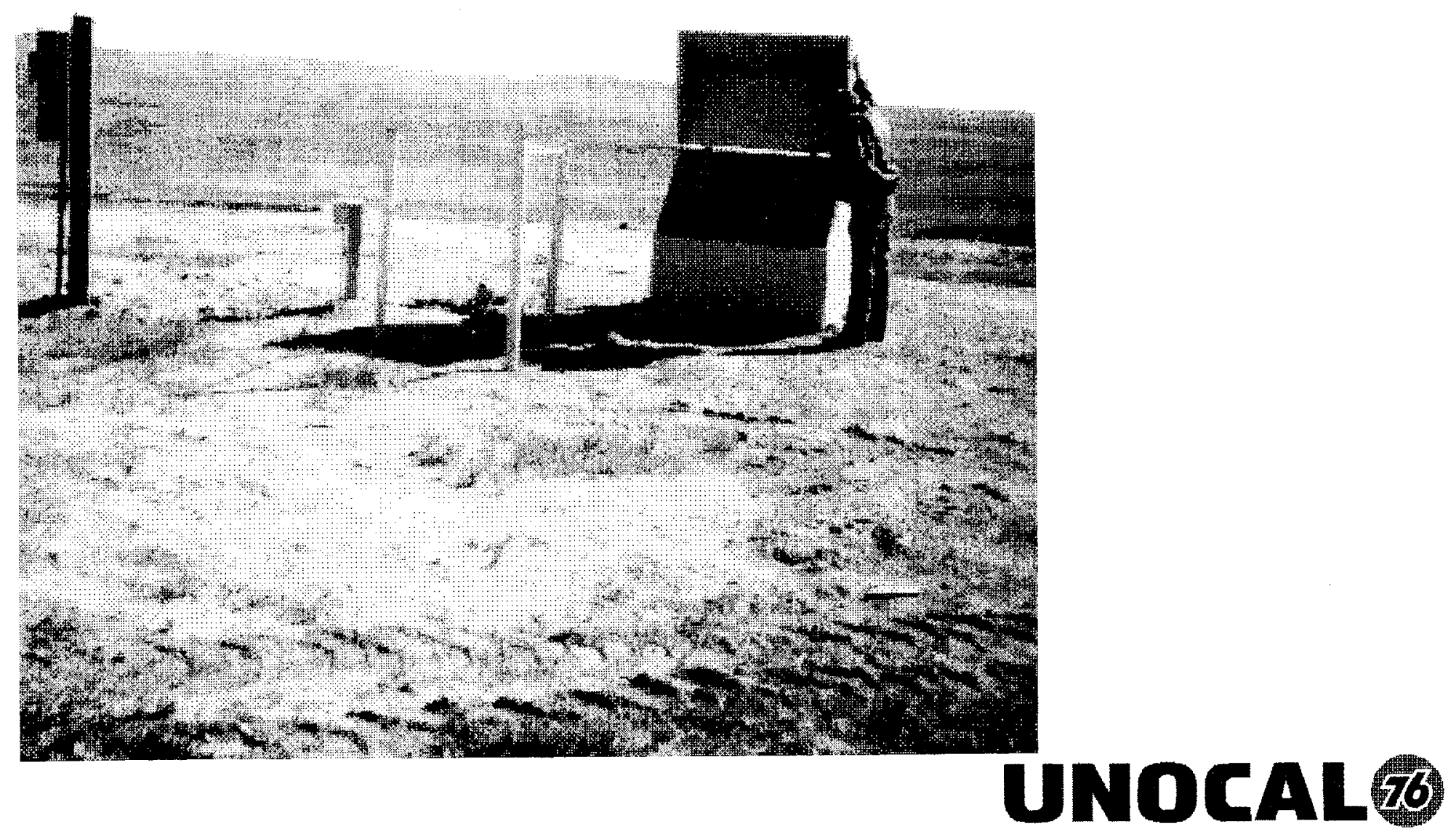




\section{CBM Producing Wellhead Powder River Basin, Wyoming}

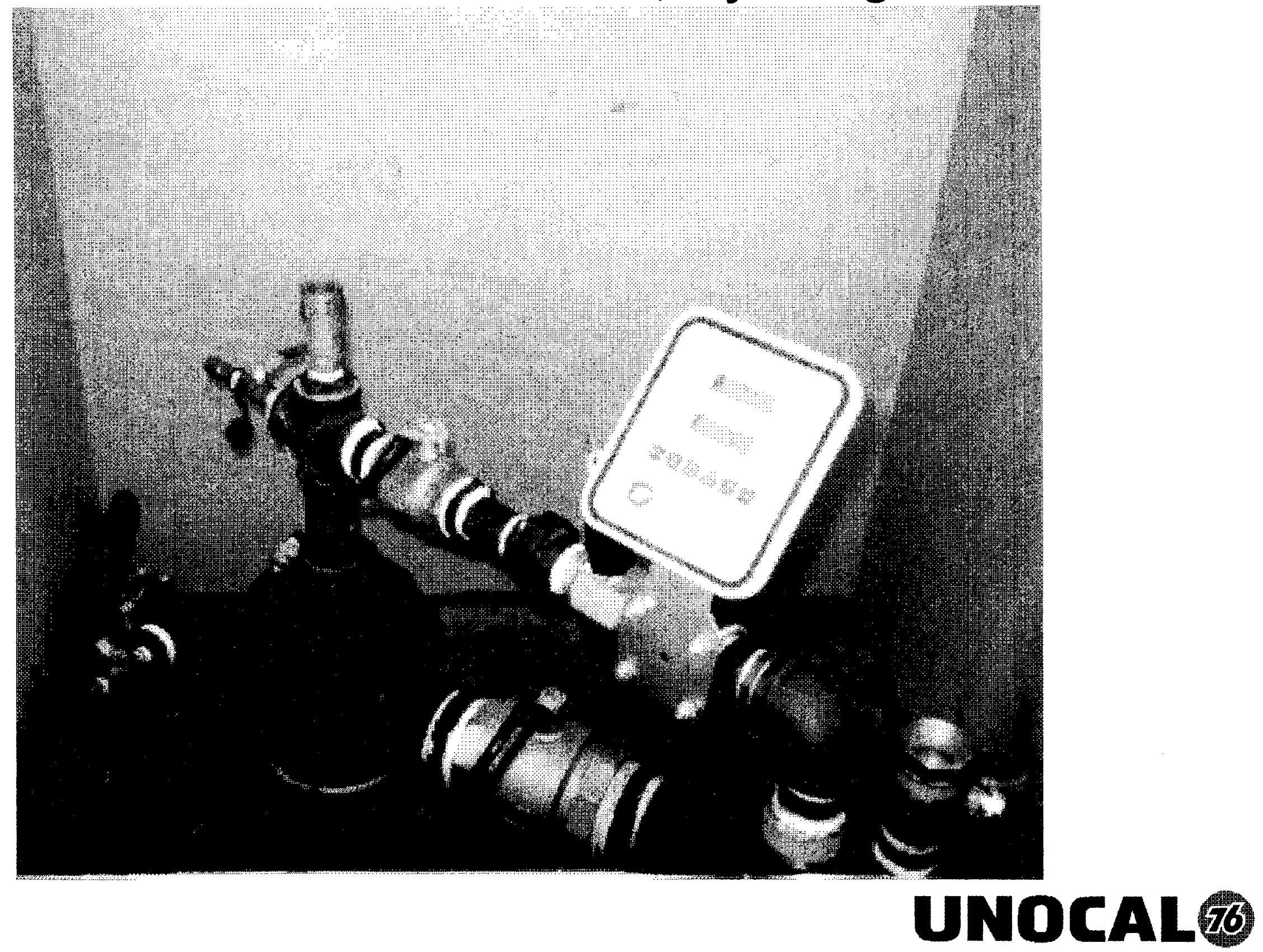




\section{CBM Gas Production Manifold Building, Powder River Basin, Wyoming}

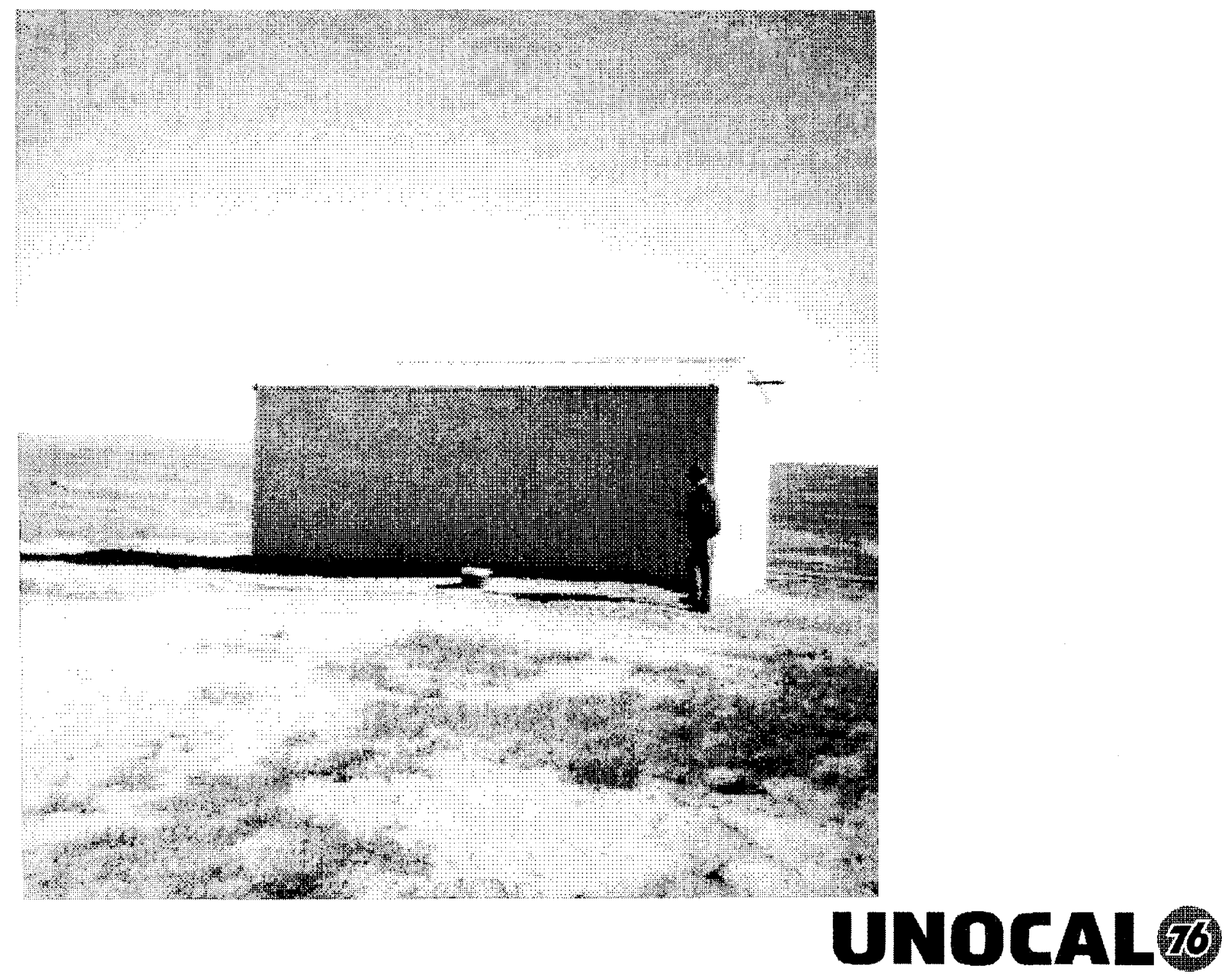




\section{Benefits to Community}

- Natural gas is environmentally friendly and low cost fuel for heating and electrical power generation

- Local contractors will provide services such as pad construction, water hauling, fuel, etc.

- Local business will benefit (Grocery, Motels, Recreation, Restaurants, Construction, etc)

- Significant Revenue to State of Alaska if Large Success

- Area around Locations will be Cleared of Refuse 


\section{Coal Bed Methane Test Program}

Phase I - Pre-Production

- Test Wells (3)

- core samples \& production tests

- Well Re-entry (1)

- completion and test of conventional reservoirs 


\section{Coal Bed Methane Test Program}

\section{Phase II - Pilot}

- 15-20 development wells

- test variations in productivity

- test drilling and completion techniques

- determine optimal well spacing and reservoir extent

- dewater and production test 


\section{PIONEER COAL BED METHANE}

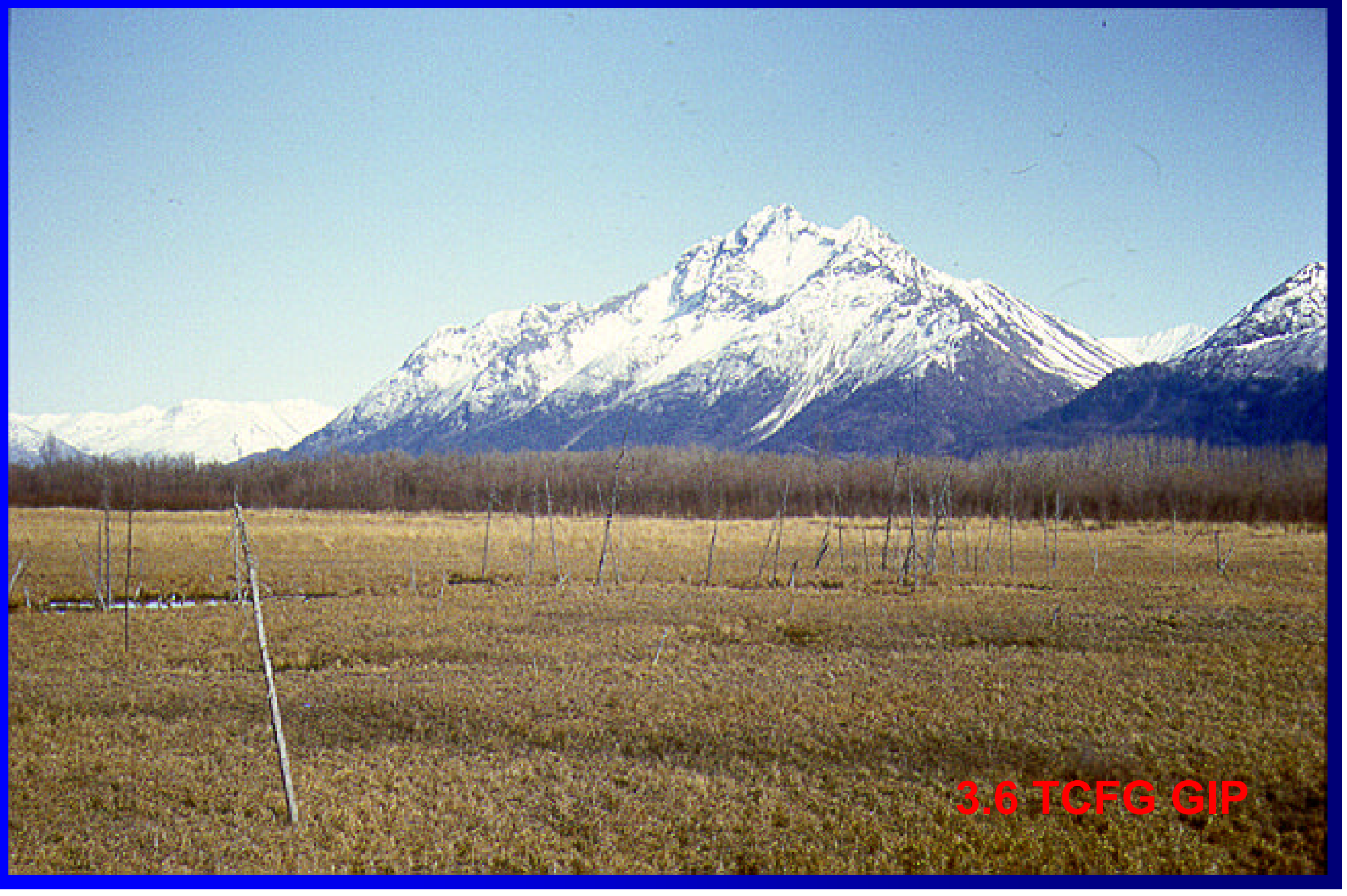




\section{Evaluation of Rural Alaska Coalbed Gas Test Drilling Demonstration Sites, from Paper to Reality}

Jim G. Clough

Alaska Division of Geological \& Geophysical Surveys

Charles E. Barker

U.S. Geological Survey

A. C. Clark

U.S. Geological Survey 


\section{Evaluation of Rural Alaska Coalbed Gas Test Drilling Demonstration Sites, From Paper to Reality}

Communities in rural Alaska currently depend on expensive diesel fuel for heating and electrical power generation. To sustain a village through the entire winter, large oil storage facilities hold the diesel fuel delivered by barges or air transport during the summer, presenting the potential for catastrophic fuel spills during transportation, and surface and ground-water pollution from leaking storage tanks. A small coalbed gas field in a remote basin, sub-commercial by international industry standards, could represent an economically viable, long-term energy resource for a small village or major mine site. In 1996, the Alaska Division of Geological and Geophysical Surveys (ADGGS), in a cooperative effort with the Texas Bureau of Economic Geology, evaluated the potential of all rural Alaskan basins using a coalbed methane producibility model to define and target coalbed methane resource potential near rural communities. Using this model three high potential prospective coal basins have been identified: (1) western North Slope Basin near Wainwright, (2) Yukon Flats Basin at Fort Yukon, and (3) Alaska Peninsula near three Chignik Bay communities. Each site has the potential for thick beds of coal or lignite oriented so that shallow drill holes would intersect thick sections of coal at an appropriate depth beneath the village. In 1997, ADGGS began a cooperative effort with the U.S. Geological Survey to develop a drilling program that would fully assess gas producibility for each of the above sites.

To test the possibility of producing shallow, economically-viable coalbed methane gas near the three village sites identified, each site must be subjected to four critical procedures: (1) Drill two exploration wells at each of the three sites; (2) Conduct pertinent geologic and hydrologic tests at each site; (3) Initiate water pumping to stimulate gas flow for subsequent flow testing at each site; and (4) Conduct a pilot gasflow test at each site to demonstrate the existence of long-term gas resources. Based on a University of Alaska economic analysis, the costs of drilling and hydrologic testing two

shallow exploratory coalbed methane gas wells at each of the three rural sites identified by ADGGS is $\$ 4.6$ million. 


\section{DIVISION OF GEOLOGICAL AND GEOPHYSICAL SURVEYS}

\section{Assessing Coalbed Methane Gas for Rural Alaska Energy Needs $(\$ 4,600,000)(D O E)$}

\section{Introduction}

Coalbed gas is a low cost, clean burning fuel that is comparable in heating value $(-1,000 \mathrm{Btu} / \mathrm{scf})$ to conventional natural gas. Communities in rural Alaska currently depend on partially subsidized diesel fuel for heating and electrical power generation. To sustain a village through the entire winter, large oil storage facilities hold the diesel fuel delivered by barges or air transport during the summer, presenting the potential for catastrophic fuel spills during transportation, and surface and ground-water pollution from leaking storage tanks.

A small coalbed gas field in a remote basin, sub-commercial by international industry standards, could represent an economically viable, long-term energy resource for a small village or major mine site. For development to occur, the costs of exploration, development and production of coalbed gas must compare favorably to the existing cost of supporting the current diesel fuel based system. Even in a favorable geologic environment, proximity of the gas to customers is critical. Economically producible coalbed gas, if present near a village or major industrial customer, would represent a tremendous quality of life resource for the community and could help create jobs as well as provide less costly heat and power.

\section{History}

In 1994 the State of Alaska funded and operated the first exploratory coalbed methane bore-hole. The hole was drilled northwest of Wasilla by the Department of Natural Resources/Division of Oil \& Gas. This project demonstrated that good coalbed methane potential exists for the northern portion of Cook Inlet basin and helped spur new private-sector coalbed gas exploration in that region. The entire state may have as much as 1,OOO-trillion cubic feet of coalbed methane. If only 10 percent of that estimate was recoverable, that 10 percent would triple current proven conventional gas reserves for Alaska*.

Beginning in 1996, the State of Alaska initiated a new program to evaluate the potential for coalbed gas in Alaska's frontier basins. The Alaska Dept. of Natural Resources, Division of Geological and Geophysical Surveys (DGGS), in a cooperative effort with the Texas Bureau of Economic Geology, evaluated the potential of all rural Alaskan basins using a coalbed methane

\footnotetext{
*The presence of coal in the subsurface does not equal coalbed gas that can be economically produced. Whereas coalbed methane resources in some basins have been successfully exploited, other basins with apparently similar geologic and hydrologic attributes have been proven to be relatively poor to moderate coalbed methane producers. For Alaska, additional parameters include the distribution and depth of permafrost, which may act as a permeability barrier to the upward migration of fluids and thermogenic gas, thus forming unconventional traps for exploration or hindering gas production. Without adequately assessing all of these parameters, the risk exists that the exploration program could (1) condemn a resource that exists but was not correctly assessed because of a poorly chosen test-site, or (2) achieve some success, but not the full potential, because the preconceived model for the test site did not tit the larger basin-scale model. Drilling a dry hole having little or no coal, or low gas contents, during early exploration attempts may severely retard future coalbed methane exploration and development in rural Alaska.
} 
producibility model to define and target coalbed methane resource potential near rural communities. $\mathrm{Th} \mathrm{e}$ coalbed methane producibility model indicates that gas productivity will be governed by the following parameters:

- thick, laterally continuous coals of high thermal maturity;

- adequate permeability;

- basinward flow of ground water through coals of high rank and gas content towards no-flow boundaries;

- possible generation of secondary biogenic gases;

- conventional and hydrodynamic trapping along no-flow boundaries to provide additional gas beyond that generated during coalitication.

Using this model, published geologic and geographic data, and on-site field investigations, three high potential prospective coal basins have been identified: (1) western North Slope Basin near Wainwright, (2) Yukon Flats Basin at Fort Yukon, and (3) Alaska Peninsula near three Chignik Bay communities.

In 1997, DGGS began a cooperative effort with the U.S. Geological Survey to develop a drilling program that would fully assess gas producibility for each of the above sites. Each site has the potential for thick beds of coal or lignite that are oriented so that shallow drill holes would intersect thick sections of coal at an appropriate depth beneath the village. The location of the coal beds near these villages both reduces the cost of drilling and the cost of building a pipeline to the nearby village should producible amounts of coalbed methane be present.

\section{Confirming Economically Viable Coalbed Methane}

\section{Phase 1: Exploration drill-holes}

Drill two exploratory drill holes at each site. The first well is used for determining the stratigraphic position of coals for subsequent coring in the nearby second well. Coals in the second well are then cored and measured for gas content by canister desorption. Samples are collected from the core for coal rank, petrology and quality analyses. The drill-hole is then logged by geophysical methods and completed to allow later testing.

\section{Phase 2: Hydrologic Testing}

Successful gas production requires finding subsurface zones (production fairways) that balance the cost of drilling and pumping the well with the presence of thick coalbeds under adequate hydraulic pressure and with the proper fracture permeability range to allow sufficient dewatering of the coal seams, thereby allowing for efficient gas production with minimal water production. The two wells are used for hydrologic testing by pumping one well and monitoring hydraulic response using pressure transducers. The well test results will be used to determine hydraulic conductivity and transmissivity of the coalbed. Environmental concerns are assessed by chemical analysis of the coalbed water produced during these tests. The data gathered by this project will quantitatively estimate the gas in place, pumping requirements for production and the disposal requirements for the produced water.

\section{Phase 3: Stimulate Gas Flow}

Generally, coalbeds are tight reservoirs and will not produce gas without stimulation. Hydrologic and geologic conditions must also be favorable for successful gas production. Dewatering the coal exposes natural fractures (cleat) that promote flow of methane gas to the well once it escapes from the coal matrix. The amount of recoverable gas is also effected by how much the reservoir pressure can be reduced by pumping. In Phase 3 , the most prospective seams identified in Phase 2 will be isolated and dewatered to stimulate gas flow.

\section{Phase 4: Pilot Testing}

The first three phases evaluate the parameters that characterize a coal seam's gas potential, but do not actually result in coalbed gas production. Phase 4 involves dewatering the coal seam (lowering the formation pressure) to induce gas flow by pumping a well for a relatively short period of time (2-4 years). During this time, the pumping rate is adjusted to achieve the maximum gas flow rate, while minimizing the volume of produced water. The goal of this phase is to prove the economic viability of the resource. 


\section{Drilling Program}

To test the possibility of producing shallow economically viable coalbed methane gas near the three village sites identified, each site must be subjected to four critical procedures:

- Drill two exploration wells at each of the three sites.

- Conduct pertinent geologic and hydrologic tests at each site.

- Initiate water pumping to stimulate gas flow for subsequent flow testing at each site.

- Conduct a pilot gas-flow test at each site to demonstrate the existence of long-term gas resources.

\section{Required Funding \$4.6 million}

The University of Alaska evaluated the costs of drilling and hydrologic testing two shallow exploratory coalbed methane gas wells at each of the three rural sites identified by DGGS. Estimated costs for drilling and testing at each of the sites range from $\$ 1.1$ to $\$ 2$ million depending on the location. Logistics alone (mobilization, site setup, shipping, and transportation) will account for $25-30 \%$ of total project costs. Actual well drilling, coring, and logging amount to $30 \%$ of the project costs. Based on this evaluation and the need to adequately assess the coalbed gas potential for rural Alaska across a spectrum of geologic, climatic, and logistical parameters, the total estimated cost for testing all three sites and conducting phases 1 through 4 procedures is $\$ 4.6$ million.

\section{Participants}

Participants in this project will be the Alaska Dept. of Natural Resources, Div. of Geological and Geophysical Surveys; U.S. Geological Survey; University of Alaska Fairbanks, Texas Bureau of Economic Geology, U.S. Department of Energy, regional Native corporations, borough governments, and local communities. 


\section{Panel Sessions:}

Land issues, Coalbed Gas Exploration on State, Federal and Native Corporation Lands 


\section{State of Alaska's Shallow Gas Leasing Program}

\section{Pirtle Bates}

Alaska Division of Oil \& Gas 


\section{Speaker Biography}

\section{Pirtle Bates}

Pirtle Bates is a Natural Resource Officer with the State of Alaska, Division of Oil and Gas. He works in the lease administration section and will be accepting and adjudicating Shallow Natural Gas lease applications received under the State's Shallow Natural Gas Leasing Program. He has been with the Division of Oil and Gas since 1995 and the Department of Natural Resources since 1988 . He previously spent 13 years in the U.S. Air Force and graduated from the University of Alaska Anchorage with a BA in Economics in 1991. 


\section{State of Alaska \\ Department of Natural Resources \\ SHALLOW NATURAL GAS (SNG) LEASING}

\section{OPENING REMARKS}

Good Morning. The legislation authorizing a Shallow Natural Gas Leasing Program by the State was passed in 1996. In reviewing the legislative history, the justification for this program rested more on social, environmental and budget considerations than on resource development. Specifically, the legislation focused on the benefits to rural residents of an inexpensive, reliable local source of energy; the reduction of environmental risks associated with diesel shipping and storage in the bush; and possible allowing the elimination or reduction of power cost subsidies. The principal objections raised to the legislation concerned the lack of public process in the adjudication and issuance of the leases and in the absence of departmental discretion in the lease issuance decision process. 


\section{State of Alaska \\ Department of Natural Resources \\ SHALLOW NATURAL GAS (SNG) LEASING}

\section{HISTORY}

$4 / 16 / 96$

$5 / 5 / 96$

$5 / 6 / 96$

$6 / 27 / 96$

$7 / 11 / 96$

$10 / 9 / 96$

$1 / 21 / 98$

9/10/98

$1 / 2000$

$2 / 29 / 2000$

CSHB 394 passed the House Yes - 37 No - 3

SCS CSHB 394 passed the Senate Yes - 20 No - 0

SCS CSHB 394 passed the House Yes - 38 No - 2

SCS CSHB 394 transmitted to the Governor

SCS CSHB 394 signed by the Governor, becoming CHAPTER 140 SLA 96

Effective date of the legislation (codified as AS 38.05.177)

Regulations to implement SNG program published for comment

Effective date of regulations

Public Notice of scheduled opening of state land to SNG leasing on February 29,200O

First SNG applications received

\section{LAND ELIGIBLE FOR SHALLOW NATURAL GAS LEASING}

All onshore state land except:

1) Land subject to an oil \& gas lease or exploration license

2) Land proposed to be subject to an oil \& gas lease or exploration license

(Commissioner can waive)

3) Mental Health Trust Lands

(Commissioner can waive with MHT concurrence)

Land subject to a coal lease, unless the applicant holds the coal lease 


\section{State of Alaska \\ Department of Natural Resources \\ SHALLOW NATURAL GAS (SNG) LEASING}

Comparison of State's Competitive and SNG Leasing Programs

\begin{tabular}{|c|c|c|}
\hline STANDARD LEASES & & SNG LEASES \\
\hline Competitive & DISPOSAL & Non-Competitive \\
\hline $\begin{array}{l}\text { Best Interest Finding } \\
\text { (State's best interest) }\end{array}$ & $\begin{array}{l}\text { DECISION } \\
\text { CRITERIA }\end{array}$ & $\begin{array}{l}\text { Benefit Determination } \\
\text { (Local resident's benefit) }\end{array}$ \\
\hline Oil, gas, and associated substances & $\begin{array}{l}\text { MINERALS } \\
\text { LEASED }\end{array}$ & $\begin{array}{l}\text { Gas, whether methane associate with and } \\
\text { derived from coal deposits or otherwise }\end{array}$ \\
\hline Full permitting required & PERMITTING & $\begin{array}{l}\text { Exempt from waste discharge permit \& } \\
\text { discharge prevention and contingency plan }\end{array}$ \\
\hline $\begin{array}{c}\text { DNR- } \$ 10,000 / \text { well (minimum) } \\
\text { AODGCC - } \$ 100,000 / \text { well or } \$ 200,000 / \text { statewide } \\
\text { DEC }-\$ 1,000,000 / \text { exploration facility }\end{array}$ & $\begin{array}{l}\text { FINANCIAL } \\
\text { RESPONSIBILITY } \\
\text { (BONDING) }\end{array}$ & $\begin{array}{l}\text { DNR-\$10,000/well (minimum) } \\
\text { AOGCC- } \$ 100,000 / \text { well or } \$ 200,000 / \text { statewide } \\
\text { DEC - } \$ 25,000 / \text { exploration facility }\end{array}$ \\
\hline Entire subsurface & LEASE HORIZON & Within 3,000 feet of the surface \\
\hline 500,000 acres onshore and offshore & $\begin{array}{c}\text { ACREAGE } \\
\text { LIMITATION }\end{array}$ & 46,080 acres \\
\hline 5,760 acres maximum & LEASE SIZE & 5,760 acres maximum \\
\hline None (minimum bonus of at least $\$ 5 / \mathrm{acre}$ ) & FILING FEE & $\$ 500$ \\
\hline $5-10$ years & LEASE TERM & 3 years (director may extend for one year) \\
\hline $12.5 \%$ minimum & ROYALTY RATE & $\begin{array}{c}6.25 \% \\
(12.5 \% \text { if produced in direct competition with } \\
\text { gas having royalty of } 12.5 \% \text { or greater })\end{array}$ \\
\hline Escalating from $\$ 1$ to $\$ 3$ per acre & RENTAL RATE & 50 cents per acre \\
\hline $\begin{array}{c}\text { None (courtesy notices are sent, but non-receipt } \\
\text { does not excuse late payments) }\end{array}$ & $\begin{array}{l}\text { RENTAL } \\
\text { BILLING }\end{array}$ & $\begin{array}{l}\text { Written notice (sent certified, return receipt } \\
\text { requested, three weeks prior to due date }\end{array}$ \\
\hline Yes & $\begin{array}{l}\text { TRANSFERRABL } \\
\text { E }\end{array}$ & $\begin{array}{c}\text { No (unless a well certified capable of } \\
\text { production exists) }\end{array}$ \\
\hline For production, certified well or if unitized & $\begin{array}{l}\text { EXTENDED } \\
\text { TERM }\end{array}$ & For production, certified well, or if unitized \\
\hline
\end{tabular}




\section{State of Alaska \\ Department of Natural Resources \\ SHALLOW NATURAL GAS (SNG) LEASING}

\section{CLOSING REMARKS}

The state received Shallow Natural Gas Lease applications since the opening on Tuesday morning. The first leases should be issued in 4 to 6 months. The Division of Oil and Gas has application packets available here today for persons interested in applying for leases on state land.

Hopefully this program will pay for itself and generate additional revenue, assist rural residents and businesses with their energy needs, reduce environmental hazards in the bush and enable further budget reductions in power cost subsidies.

Thank you. 
APPLICATION PACKET

for

SHALLOW NATURAL

GAS LEASING

PROGRAM 


\section{Sec. 38.05177 Shallow natural gas leases.}

(a) The provisions of this section

(1) apply to gas, whether methane associated with and derived from coal deposits or otherwise, developed from a source that is onshore and within 3,000 feet of the surface; and

(2) do not apply to authorize lease of

(A) land

(i) that is subject to an oil and gas exploration license or lease issued under AS 38.05.131 - 38.05.134; or

(ii) that is leased under AS 38.05.180;

(B) the land

(i) that is proposed to be subject to an oil and gas exploration license or lease issued under AS 38.05.131 - 38.05.134; or

(ii) that is described in and part of a proposed oil and gas leasing program prepared under AS 38.05.180 (b); however, the commissioner may waive the limitations of this subparagraph;

(C) the land that is held under a coal lease entered into under AS 38.05.150, unless the applicant for a shallow natural gas lease is also the lessee under AS 38.05.150 of that land; or

(D) the valid existing selections of the Alaska Mental Health Trust Authority made for the purpose of reconstituting the mental health trust established under the Alaska Mental Health Enabling Act, P.L. 84-830,70 Stat. 709 (1956), that become subject to management under AS 38.05.801, or of land that has been designated by law for or is subject to designation for conveyance to the Alaska Mental Health Trust Authority; however, after consultation with the Alaska Mental Health Trust Authority, the commissioner may waive the limitations of this subparagraph.

(b) For the purpose of exploring for and developing shallow natural gas reservoirs, upon application, the director may lease to a person land for which the state owns the subsurface rights. A person applying for a lease under this subsection

(1) shall specify the area to be leased; the area to be leased may not exceed 5,760 acres; a lessee may not hold more than 46,080 acres of land under leases entered into under this section;

(2) may be required to pay a reasonable application fee of up to $\$ 500$.

(c) Within 20 days of receipt of a lease application, the director shall give notice under AS 38.05.945 of receipt of the lease application and call for comments from the public. The director's call for public

comments must provide opportunity for public comment for a period of 60 days. If, after review of 
information received during the public comment period, the director determines that the discovery of a local source of natural gas would benefit the residents of an area, the director shall execute a lease for the area described in (b) of this section. The director shall execute the lease within 90 days after the close of the public comment period or, if review is required under AS 46.40, within 30 days after the final consistency determination is made under AS 46.40, whichever is later. A lease entered into under this subsection gives the lessee the exclusive right to explore for, develop, and produce, for a term of three years, natural gas on the state land described in the lease; the right to explore for, develop, and produce is limited to gas derived from natural gas within 3,000 feet of the surface.

(d) A lease shall be automatically extended if and for so long thereafter as gas is produced in paying quantities from the lease and the lessee continues to meet all requirements of the lease. A lease issued under this section covering land on which there is a well capable of producing gas in paying quantities does not expire because the lessee fails to produce gas unless the lessee is allowed reasonable time to place the well on a producing status. If drilling has commenced on the expiration date of the primary term of the lease and is continued with reasonable diligence, including such operations as redrilling, sidetracking, or other means necessary to reach the originally proposed bottom hole location, the lease is extended for one year and for so long thereafter as gas is produced in paying quantities. A gas lease issued under this section that is subject to termination by reason of cessation of production does not terminate if, within 90 days after production ceases or a longer period determined at the discretion of the director, reworking or drilling operations are commenced on the land under lease and are thereafter conducted with reasonable diligence during the period of nonproduction. In addition, upon application by the lessee, the director may once extend a lease issued under (c) of this section for a period of not more than three years.

(e) The director may, following the procedures described in (c) of this section, adjust the boundaries of a lease entered into under this section as may be necessary to ensure development of natural gas within a reasonably compact area; a lease as adjusted under this subsection remains subject to the acreage limitations set out in (b)(l) of this section.

(f) A shallow gas lease must provide for payment to the state of annual rent in the amount of 50 cents per acre. The rent is due and payable on the dates determined in the lease. The director shall mail the lessee one written notice, certified return receipt requested, three weeks before the due date of the rent. If the lessee fails to pay rent, the director shall terminate the lease.

(g) The royalty payable on natural gas produced from a lease

(1) is

(A) 12.5 percent of the value of production removed or sold from the lease for gas exported from the state or gas that is produced in direct competition with gas on which a royalty at a rate of at least 12.5 percent is payable; and

(B) except as provided in (A) of this paragraph, 6.25 percent of the value of the production removed or sold from the lease; and

(2) shall be based upon production delivered in pipeline quality and free of all lease expenses, including but not limited to separation, cleaning, dehydration, gathering, salt water disposal, and preparation for transportation off the lease. 
(h) A lease issued under this section is subject to the following terms and conditions and may be terminated by the director in the event of a breach of a term or condition:

(1) the lessee may surrender the lease or relinquish part of the lease at any time;

(2) the lease may not be transferred or assigned until a well capable of production of gas in paying quantities has been drilled on the lease; however, this paragraph does not prohibit the lessee from entering into a farm out agreement or similar arrangement with a third party under which the third party assists in exploration and development of production from the lease if the agreement or arrangement does not require a payment of consideration by the third party to the lessee, except that the lessee may retain an overriding royalty interest in the lease or may retain a net profit or other production payment.

(i) The applicant for a lease is responsible for conducting a title search for the area described in the lease application.

(j) A lease does not give the lessee the right to produce oil. A lease does not give the lessee the right to produce gas from sources that are not within 3,000 feet of the surface. If a well drilling for natural gas under a lease authorized by this section penetrates a formation capable of producing gas below 3,000 feet of the surface or penetrates a formation capable of producing oil, the owner or operator

(1) shall notify the department and the Alaska Oil and Gas Conservation Commission; and

(2) may not conduct further operations in the drilled well until the facility complies with all applicable laws and regulations relating to oil and gas exploration and production; however, this paragraph does not prevent the owner or operator from conducting activities that may be required by the Alaska Oil and Gas Conservation Commission to plug, plug-back, or abandon a well.

(k) The commissioner of natural resources may adopt only the regulations that are reasonable and that are necessary to implement, interpret, or make specific the provisions of this section or to establish procedures to govern application of the provisions of this section.

(1) A lessee obtaining a lease under this section may exercise the rights authorized by this section and the lease. The rights granted by the lease must be exercised in a manner that does not unreasonably interfere with eventual development of other mineral deposits on the land leased. However, in a lease entered into under AS 38.05.150 for land that is already leased under this section, coal may not be mined or extracted by the coal lessee from the coal lease without prior agreement with the lessee holding the lease issued under this section.

(m) Except as otherwise specifically provided in this section, the provisions of AS 38.05.135-38.05.184 apply to leases entered into under this section.

(n) In this section, "lease" means a shallow gas lease authorized by this section. 


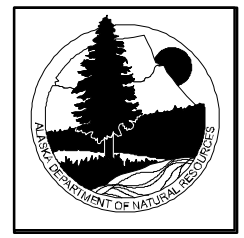

\title{
APPLICATION FOR SHALLOW NATURAL GAS LEASE
}

Under the provisions of AS 38.05.177 the undersigned applicant(s) apply for a Shallow Natural Gas Lease of the land described in Section 2 below. The undersigned applicant(s) certify that the information provided in this application is true, accurate and complete, and that the applicant(s) listed in Section 3 of this application are qualified to hold an interest in a lease under 11 AAC 82.200 and 11 AAC 82.205 , or have included the required documents and information for qualification with this application, and have signed this application. The undersigned applicant(s) hereby authorize the person identified in Section 1 below to act as their designated agent for receipt of all notices and all communication with the Department of Natural Resources concerning this application.

\section{SECTION 1: Applicant(s) Designated Agent}

\author{
Name:
}

Physical Address
Mailing Address

Telephone:

Fax (optional):

nail (optional):

The designated agent will be the only point of contact for official correspondence between the state and the applicants during the application process.

\section{SECTION 2: Land Requested in the Application}

\section{SECTION TOWNSHIP RANGE MERIDIAN}

The area of land requested in the application may not exceed 5,760 acres (9 sections) and must be described by section, township, range and meridian. It must be compact in form, consisting of full sections which are contiguous (sections touching only at a point are not contiguous), and the overall length of the land requested must not exceed four times the width of the land. 11 AAC 82.510. If a lease is issued on the basis of this application, it will include only the land that is available for lease within the requested area. 


\section{SHALLOW NATURAL GAS LEASE APPLICATION FORM (continued)}

\section{SECTION 3: Applicant(s)}

$\%$ of Lease

Interest

Name of Applicant

Authorized Signature

Date

All persons (including corporations and associations) who will receive an interest, by virtue of any agreement or understanding, oral or written, in a Shallow Natural Gas Lease issued on the basis of this application, must be identified as an applicant in this section and provide an authorized signature. Each applicant must be qualified to hold an interest in a lease under 11 AAC 82.200 and 11 AAC 82.205 , or have included the required documents and information for qualification with this application. The lease-interest percentages listed in this section must be represented by numbers with the fractional interest carried out to no more than five decimal places. The total of all lease-interests must equal 100.00000 percent.

\section{Shaded Area is for Official Use Only}

(1) Application received:

(2) Receipt \# for Filing Fee

Date:

Time:

By:

ADL

Title:

(3) When application was determined complete, if not complete at time of filing:

Date:

Time:

By:

Title: 


\section{SECTION 4: Information Required for Processing Shallow Natural Gas}

Applications

1) List all communities consisting of 25 people or more that are located within 25 miles in any direction of the land described in the application.

2) List all ANCSA Village and Regional Corporations that own land within 25 miles in any direction of the land described in the application.

3) Describe how discovery of a source of natural gas on the land described in the application would benefit the residents of each area identified above?

(Continue on reverse) 
4) Is any part of the land described in the application within a Coastal Resource District (AS 46.40)?

Yes No

If yes, in what district or districts?

5) Is any part of the land described in the application within a specially designated area, such as a State Park, State Game Refuge, Critical Habitat Area, or other designated area?

Yes _ No

If yes, identify each designated area in which any part of the land described in the application is located?

6) Is any part of the land described in the application within a borough, municipality or city?

Yes No

If yes, in which ones?

7) Does any part of the land described in the application contain University Lands?

Yes No

If yes, identify the location of the University Lands by section, township and range.

8) Does any part of the land described in the application contain Mental Health Trust Lands?

Yes No

If yes, identify the location of the Mental Health Trust Lands by section, township and range.

9) Attach a USGS 1:63,360 Topographic Map showing the land described in the application. 


\section{SHALLOW NATURAL GAS LEASE APPLICATION INSTRUCTIONS}

General information: This instruction sheet provides information to assist applicants in completing the Shallow Natural Gas Lease Application form. The staff of the Department of Natural Resources, Division of Oil and Gas (Division) are available to answer additional questions about the application process. Contacts and phone numbers are listed at the end of these instructions.

An applicant for a Shallow Natural Gas Lease must file a fully completed Shallow Natural Gas Lease form obtained from the Division, or an exact image copy of the application form, and a non-refundable $\$ 500.00$ filing fee for each application submitted. Application forms and filing fees may be filed by mail or personal delivery to the Division's office at the address on the application form. Applications may also be filed by wire transfer (telegram, radiogram or cablegram), but will be considered only if they are confirmed within 15 days by filing a fully completed and signed application form and the filing fee.

Applications will be considered on a first-come, first-served basis. The priority of an application for a specific area of land will be determined by the date and time the fully completed application is received and date-stamped by the Division. Application forms that are filed by wire transfer will be date-stamped when they are received by the Division, but will not establish a priority unless the application is confirmed within 15 days by filing a fully completed and signed application form and the filing fee.

An incomplete application will not be given priority. If the Division receives an incomplete application form, or an application not accompanied by the proper filing fee, it will inform the applicant by letter that information or the filing fee is missing and must be submitted before the application will be considered. The priority of an incomplete application will be determined by the time the Division receives and date-stamps all information necessary to complete the application.

Filing Fee: A non-refundable filing fee of $\$ 500.00$ must accompany each application form. An application is not complete if the filing fee is not included.

SECTION 1: Applicant(s) Designated Agent. On each application, one individual must be designated as the applicant(s) agent for all interactions with the Division during the lease application process. The designated agent must have authority to act on behalf of the applicant(s) and will be the applicant(s) official contact for all correspondence and other contact between the Division and the applicant(s). Applicant(s) may replace their designated agent only by filing a notarized letter signed by all the applicants informing the Division that the designated agent has been replaced, and providing the name and address of the new designated agent. The letter of replacement must be filed at the Division's office. An application is not complete unless it has identified a designated agent. 
SECTION 2: Land Reauested in the Application. On the application form, or on application by wire transfer, the entire area of land requested must be described by section, township, range, and meridian. The area of land must consist of whole sections that are compact and contiguous and consistent with the other legal specifications summarized in the application form. An applicant may apply for no more than nine sections of land in each application. If a shallow natural gas lease is issued, it will include only the state land within the application area that is available for lease, which may be less than the total area of land described in the application. An application is not complete if it fails to describe the land as required.

SECTZON 3: Applicant(s) and Signatures. State regulations require that "applications must be signed by or on behalf of each person who will receive any interest in any lease or permit if issued, by virtue of any agreement or understanding, oral or written." 11 AAC 82.500. The term "person" includes corporations and associations of persons. Every person who will be entitled to receive any interest in a lease that is issued on the application must be listed as an applicant, and must sign the application form. The total of the fractional interests of all applicants must equal 100.00000 percent exactly. An application that does not list every person who will receive an interest in the lease and include each interest holders' authorized signature is not complete.

Applicants must be qualified, Each applicant must be qualified under 11 AAC 82.200. Applicants may pre-qualify, or submit the qualification documentation required under 11 AAC 82.205 with the application form. An application is not be complete until all applicants are qualified.

SECTION 4: Additional Information. The information requested in this section is necessary for the Division to publish the public notice required under AS 38.05.177(c) after an application is received. Failure to provide this information will not affect the priority of an otherwise complete application, but will delay processing of the application. Most of the information requested in this section is available at the Department of Natural Resources Public Information Center, currently located in Suite 200 of the Frontier Building at and C Streets, Anchorage.

For more information, contact:

Pirtle Bates, Jr.

Phone: (907) 269-8810

Fax: (907) 269-8943
Jim Haynes

Phone: (907) 269-8775

Fax: (907) 269-8943
Matt Rader

Phone: (907) 269-8776

Fax: (907) 269-8943 
COMPACT \& CONTIGUOUS
R $1 \mathrm{E}$
R $2 \mathrm{E}$
R 3 E

\begin{tabular}{|c|c|c|c|c|c|c|c|c|c|c|c|c|c|c|c|c|c|}
\hline 6 & 6 & 4 & 3 & 2 & $1 \%$ & 6 & 5 & 4 & 13 & 2 . & 9 & 6 & 5 & 4 & 3 & 2 & 1 \\
\hline 7 & 8 . & 4 & 10 & 11 & 12 & 7 & 8 & 9 & 10 & 11 & 12 & 7 & 8 & 9 & 10 & 11 & 12 \\
\hline 18 & 17 & 6 & 15 & 14 & 13 & 18 & 17 & 16 & 15 & 14 & 13 & 18 & 17 & 16 & 15 & 14 & 83 \\
\hline 19 & 20 & 21 & 22 & 23 & 24 & 19 & 20 & 21 & 22 & 23 & 24 & 19 & 20 & 21 & 22 & 23 & 24 \\
\hline 30 & 29 & 28 & 27 & 26 & 25 & 30 & 20. & 28 & 27 & 26 & 25 & 30 & 29 & 28 & 27 & 26. & 25 \\
\hline 31 & 32 & 33 & 34 & 35 & 36 & 31 & 32 & 33. & 34 & 35 & 36 & 31 & 32 & 33 & 34 & 35 & 36 \\
\hline 6 & 5 & 4 & 3 & 2 & 1 & 6 & 5 & 4 & 3 & 2 & 1 & 6 & 5 & 4 & 3 & 2 & 1 \\
\hline 7 & 8 & 9 & 10 & 14 & 12 & $7 \%$ & 8 & 9 & 10 & 11 & 12 & 1 & 8 & 9 & 10 & 11 & 12 \\
\hline 18 & 17 & 16 & 15 & 14 & 13 & 18 & 17 & 16 & 15 & 14 & 13 & 18 & 17 & 16 & 15 & 14 & 13 \\
\hline 19 & 20 & 21 & 22 & 23 & 24 & 19 & 20 & 21 & 22 & 23 & 24 & 19 & 20 & 21 & 22 & 23 & 24 \\
\hline 30 & 29 & 28 & 27. & 26 & 25 & 30 & 29 & 28. & 27 & 26 & 25 & 30 & 29 & 28 & 27 & 26 & 25 \\
\hline 31 & 32 & 33 & 34 & 35 & 36 & 31 & 32 & 33 & 84 & 35 & 36 & 31 & 32 & 33 & 34 & 35 & 36 \\
\hline 6 & 5 & 4 & 3 & 2 & 1 & 6 & 5 & 4 & 3 & 2. & 1 & 6 & 5 & 4 & 3 & 2 & 1 \\
\hline 7 & 8 & 9 & 10 & 11 & 12 & $7 \%$ & 8. & 9 & 10 & 11 & 12 & 7 & 8 & 9 & 10 & 11 & 12 \\
\hline $18:$ & 17 & 16 & 15 & 14 & 13 & 18 & 17 & 16 & 15 & 44 & 13 & 18 & 17 & 16 & 15 & 14 & 13 \\
\hline 19 & 20 & 21 & 22 & 23 & 24 & 19 & 20 & 21 & 22 & 23 & 24 & 19 & 20 & 21 & 22 & 23 & 24 \\
\hline 30 & 29 & 28 & 27. & 26 & 25 & 30 & 29 & 28 & 27. & 28 & 25 & 30 & 29 & 28 & 27 & 26 & 25 \\
\hline 31 & 32 & 33 & 34 & 35 & 36 & 31 & 32 & 33 & 34 & 85 & 8 & 31 & 32 & 33 & 34 & 35 & 36 \\
\hline
\end{tabular}

NOT COMPACT \& CONTIGUOUS

\begin{tabular}{|c|c|c|c|c|c|c|c|c|c|c|c|c|c|c|c|c|c|}
\hline & & & & & & & & & E & & & & & & & & \\
\hline 6 & 5 & 4 & 3 & 2 & 1 & 6 & . & 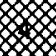 & 3 & 2 & 1 & 6 & 5 & 4 & 3 & & \\
\hline 7 & 8 & 9 & 10 & 11 & 12 & 7 & & 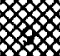 & 10 & 11 & 12 & 7 & 8 & 9 & 10 & & \\
\hline 18 & & & (1) & 14 & & 18 & 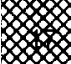 & 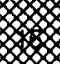 & 15 & 14 & 13 & 18 & 17 & 16 & 15 & 9 & 13 \\
\hline 19 & & & 22 & 23 & & 19 & 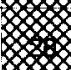 & . & 22 & 23 & 24 & 19 & 20 & 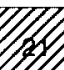 & 34 & 23 & 24 \\
\hline 30 & & & 27 & 26 & 25 & 30 & 29 & 28 & . & 26 & 25 & 30 & 29 & 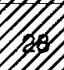 & $P I$ & 26 & 25 \\
\hline 31 & 32 & \begin{tabular}{l|l}
2 & 33
\end{tabular} & 34 & 35 & 36 & 31 & 32 & 33 & 34 & 35 & 36 & 31 & 32 & 33 & 34 & 35 & 36 \\
\hline
\end{tabular}




\section{APPLICATION PROCESSING STEPS}

1) Application filed

Day 1

(The processing timeline begins when a completed application form is filed with the division. If an application is incomplete, the division will send a letter to the applicant requesting the missing information be provided. An incomplete application will not be processed, and no priority will attach, until all missing information is provided.)

2) A Public Notice of the application will be published in newspapers and the 60-day public comment period will begin

by Day 20

3) You will receive a review package

Day 25 (approx.)

(This will be the same package sent to other government agencies and interested parties)

4) You will receive a Preliminary Benefit Determination, indicating whether

Day 95 (approx.) or not a lease is to be issued, and be given the opportunity to comment

(If in a Coastal Resource District you will also receive a Proposed Consistency Determination)

5) You will receive a Final Benefit Determination, indicating whether or not a

Day 110 (approx.) lease will be issued, with instructions on how to appeal a decision with which you disagree

(If in a Coastal Resource District you will also receive an appealable Final Consistency Determination)

6) Mailing of an Award Notice with instructions on how to execute the

Day 120 (approx.) lease, if a lease is to be issued

7) If there is no appeal of the Final Benefit Determination by any party, a

Day 170 (approx.) lease will be executed and issued by the state or the application will be rejected and closed as indicated in the determination 


\title{
STATE OF ALASKA DEPARTMENT OF NATURAL RESOURCES
}

\author{
Noncompetitive Shallow Natural Gas Lease $\quad$ ADL No.
}

THIS NONCOMPETITIVE SHALLOW NATURAL GAS LEASE ("this lease") is entered into between the State of Alaska acting through the Department of Natural Resources ("the state"), and

("the lessee") whether one or more, whose sole address for purposes of notification is as shown in Paragraph 30.

In consideration of the cash payment made by the lessee to the state, which payment includes the first year's rental, and subject to the provisions of this lease, including applicable stipulation(s) and mitigation measure(s) attached to this lease and by this reference incorporated into this lease, the state and the lessee agree as follows:

1. GRANT. (a) Subject to the provisions in this lease, the state grants and leases to the lessee, without warranty, the exclusrve right to explore for, develop, and produce natural gas from the surface to a true vertical depth of 3,000 feet below the surface and excluding all greater depths in or under the tract of land, described in subparagraph (b), below, containing approximately acres, more or less, and the non-exclusive right to install pipelines and build structures on the leased area to find, produce, save, store, treat, process, transport, take care of, and market all natural gas and to house and board employees in its operations on the leased area. The rights granted by this lease are to be exercised in a manner which will not unreasonably interfere with the rights of any permittee, lessee or grantee of the state consistent with the principle of reasonable concurrent uses as set out in Article VIII, Section 8 of the Alaska Constitution and must be exercised in a manner that does not unreasonably interfere with eventual development of other mineral deposits on the leased area.

(b) The tract of land subject to this lease (the "leased area") is described as:

(c) For the purposes of this lease, the leased area contains the legal subdivisions as shown on the attached plat marked Exhibit $A$. If the leased area is described by protracted legal subdivisions and, after the effective date of this lease, the leased area is surveyed under the public land rectangular system, the boundaries of the leased area are those established by that survey, when approved, subject, however, to the provisions of applicable regulations relating to those surveys. If for any reason the leased area includes more acreage than the maximum permitted under applicable law (including the rule of approximation authorized in AS 38.05.145 and defined in AS 38.05.965(18)), this lease is not void and the acreage included in the leased area must be reduced to the permitted maximum. If the state determines that the leased area exceeds the permitted acreage and notifies the lessee in writing of the amount of acreage that must be eliminated, the lessee has 60 days after receipt of the such notice to file an instrument surrendering at least the amount of acreage that must be eliminated from the leased area, which must be one or more legal subdivisions or other shape approved by the state. Any subdivision surrendered must be located on the perimeter of the leased area as originally described. If an instrument surrendering the acreage is not filed within 60 days, the state may terminate this lease as to the acreage that must be eliminated by mailing notice of the termination to the lessee,

(d) If the state's ownership interest in the natural gas in the leased area is less than an entire and undivided interest, the grant under this lease is effective only as to the state's interest in that natural gas, and the royalties and rentals provided in this lease must be paid to the state in the proportion that the state's interest bears to the entire undivided fee.

(e) The state makes no representations or warranties, express or implied, as to title, or access to, or quiet enjoyment of, the leased area. The state is not liable to the lessee for any deficiency in title to the leased area, nor is the lessee or any 
successor in interest to the lessee entitled to any refund due to deficiency in title for any rentals, royalties or other fees paid under this lease.

2. RESERVED RIGHTS. (a) The state, for itself and others, reserves all rights not expressly granted to the lessee by this lease. These reserved rights include, but are not limited to:

(1) the rights to explore for, develop, and produce natural resources other than natural gas on or from the leased

area;

(2) the rights to establish or grant easements, leases, permits, and rights-of-way for any lawful purpose, including without limitation for facilities, well sites, well bores, shafts and tunnels necessary or appropriate for the working of the leased area for natural resources and minerals, other than natural gas, or other lands for natural resources and minerals including natural gas;

(3) the right to dispose of land within the leased area for facilities, well sites and well bores of wells drilled from or through the leased area to explore for or produce oil, natural gas, or other minerals and natural resources, in and from lands not within the leased area; and

(4) the rights otherwise to manage and dispose of the surface of the leased area or interests in that land by grant, lease, permit, or otherwise to third parties.

(b) The rights reserved may be exercised by the state, or by any other person or entity acting under authority of the state, in any manner that does not unreasonably interfere with or endanger the lessee's operations under this lease.

3. TERM. This lease is issued for an initial primary term of three years from the effective date of this lease. The term may be extended as provided in Paragraph 4 below and additionally, upon application by the lessee, the state may extend the primary term once for a period of not more than three years.

4. EXTENSION. (a) This lease will be extended automatically beyond the primary term if and for so long as natural gas is produced in paying quantities from the leased area and the lessee continues to meet all requirements of this lease.

(b) This lease will be extended automatically beyond the primary term if it is committed to a unit agreement approved or prescribed by the state. It will remain in effect for so long as it remains committed to a valid unit agreement.

(c) If the lessee has started to drill a well whose bottom hole is in the leased area before the expiration date of the primary term and continues to drill with reasonable diligence, this lease will continue in effect for 90 days after expiration of the primary term or for so long thereafter as natural gas is produced in paying quantities from the leased area. For purposes of this paragraph, "drilling" includes testing, redrilling, sidetracking, or other means necessary to reach the originally proposed bottom hole location.

(d) If the lessee stops producing natural gas in paying quantities after the expiration of the primary term, this lease will not terminate if the lessee starts drilling within 90 days or a longer period determined at the discretion of the state. This lease will remain in effect for so long as the lessee continues drilling and operations with reasonable diligence. If the drilling results in the production of natural gas, this lease will remain in effect for so long as natural gas is produced in paying quantities from the leased area. For purposes of this paragraph, "drilling" includes testing, redrilling, sidetracking, or other means necessary to reach the originally proposed bottom hole location.

(e) If there is a well certified by the commissioner as capable of producing natural gas in paying quantities on the leased area, this lease will not expire because the lessee fails to produce the natural gas. If, however, the state gives written notice to the lessee, allowing a reasonable time, which will not be less than six months after notice, to place the well into production, and the lessee fails to do so, this lease terminates automatically at the end of the last day of the time specified by the state. If production is established within the time allowed, this lease is extended only for so long as natural gas is produced in paying quantities from the leased area.

(f) If the state directs or approves in writing a suspension of all operations on or production from the leased area (except for a suspension necessitated by the lessee's negligence), or if a suspension of all operations on or production from the leased area has been ordered under federal, state, or local law, the lessee's obligation to comply with any express or implied provision of this lease requiring operations or production will be suspended, but not voided, and the lessee shall not be liable for damages for failure to comply with that provision. If the suspension occurs before the expiration of the primary term, the primary term will be extended at the end of the period of the suspension by adding the period of time lost under the primary term because of the suspension. If the suspension occurs during an extension of the primary term under this paragraph, upon removal of that suspension, the lessee will have a reasonable time, which will not be less than six months after notice that the suspension has been removed, to resume operations or production. For the purposes of this subparagraph, any suspension of operations or production specifically required or imposed as a term of sale or by any stipulation(s) or mitigation measure(s) made a part of this lease will not be considered a suspension ordered by law.

(g) If the state determines that, after efforts made in good faith, the lessee has been prevented by force majeure from performing any act that would extend this lease beyond the primary term, this lease will not expire during the period of force majeure. If the force majeure occurs before the expiration of the primary term, the primary term will be extended at the 
end of the period of force majeure by adding the period of time lost under the primary term because of the force majeure. If the force majeure occurs during an extension of the primary term under this paragraph, this lease will not expire during the period of force majeure plus a reasonable time after that period, which will not be less than 60 days, for the lessee to resume operations or production.

(h) Nothing in subparagraphs ( $f$ ) or $(g)$, above, suspends the obligation to pay royalties to the state from operations on the leased area that are not affected by any suspension or force majeure, or suspends the obligation to pay rentals.

5. RENTALS. (a) The lessee shall pay annual rental to the state of $\$ 0.50$ per acre or fraction of an acre.

(b) The lessee shall pay the annual rental to the state (or any depository designated by the state in writing with at least 60 days notice to the lessee), on or before the annual anniversary of the effective date this lease ("anniversary date"). The state shall mail to the lessee one written notice that rentals are due, by certified mail with return receipt requested, three weeks before the anniversary date. If the state's (or depository's) office is not open for business on the anniversary date, the time for payment is extended to include the next day on which that office is open for business. If the annual rental is not paid timely when due, this lease automatically terminates as to both parties at 11:59 p.m., Alaska Standard Time, on the date on which the rental payment was due.

6. ROYALTY ON PRODUCTION. Except for natural gas used on the leased area by the lessee for development and production of natural gas or unavoidably lost, the lessee shall pay to the state as a royalty:

(a) 12.5 percent in amount or value of the natural gas removed or sold from the leased area where the natural gas is exported from Alaska or that is produced and marketed in direct competition with gas on which a royalty at a rate of at least 12.5 percent is payable; or

(b) except as provided in (a) of this paragraph, 6.25 percent of the amount or value of the natural gas removed or sold from the leased area.

7. VALUE. (a) To compute royalties due under this lease, the value per Mcf of royalty natural gas shall be determined each month at the lease or unit boundary. Royalty Valueps (RVG) is determined monthly for each lease. To calculate RVG, the lessee first determines whether the Minimum Value of Gas (MVG) or the Transaction Value of Gas (TVG) is higher for each separate transaction. The higher of MVG or TVG is then multiplied by the volume of gas disposed of in that transaction during that month. The total of all of the products of the MVG or TVG times the volume for each transaction that month is then divided by the total volume of gas produced by the lessee and disposed of that month to determine the RVG for that month.

(1) MVG is determined for each lease according the following formula:

$\mathrm{MVG}=\$ 1.40 / \mathrm{mcf} X\left(\mathrm{WC}\right.$ Gasoil $_{\text {cunent month }} /$ \$22.50)

where WC Gasoilcunentmonth is the average of West Coast Waterborne Gasoil prices ( $\$ /$ bbl) as reported in Platt's Oilgram Price Report for the production month.

(2) TVG is determined for each disposition of gas. TVG is equal to the cash value of all consideration received during the production month for the sale or exchange of the gas.

(b) The state may change the methodology for calculating the components of the royalty value formula in (a) above by regulation.

(c) RVG may never be less than zero.

(d) Exhibit $B$ to this lease demonstrates how this paragraph shall be applied to calculate RVG.

8. ROYALTY IN VALUE. (a) Except to the extent that the state elects to receive all or a portion of its royalty in kind as provided in Paragraph 9, below, the lessee shall pay to the state the value of all royalty natural gas as determined under Paragraph 7, above. The amount of Royalty to be paid in value shall be based upon the volume of production delivered in pipeline quality at the point of delivery. Royalty in value shall be free and clear of all lease expenses (and any portion of those expenses that is incurred away from the leased area), including, but not limited to, expenses for separating, cleaning, dehydration, gathering, saltwater disposal, compression, processing and preparing the natural gas for transportation off the leased area.

(b) All royalty payable in money to the state must be paid on or before the last federal banking day of the calendar month following the month in which the natural gas is produced. Royalty in value payments which are not paid when due under this lease or the amount which is subsequently determined to be due to the state or the lessee as the result of a redetermination will bear interest from the last federal banking day of the calendar month following the month in which the natural gas was produced, until the obligation is paid in full. The amount of all royalty in value payments that are not paid when due under this lease or that are subsequently determined to be due as the result of a redetermination shall bear interest from the date the obligation accrued, until paid in full, at the rate provided in AS 38.05.135(d) or AS 38.05.135(d) as later amended. 
(c) Royalty payments must be accompanied by such information relating to valuation of royalty as the state may require including, but not limited to, sales contracts, metering data, evidence of sales, shipments, and amounts of gross natural gas produced.

9. ROYALTY IN KIND. (a) At the state's option, which may be exercised from time to time upon not less than 90 days notice to the lessee, the lessee shall deliver all or a portion of the state's royalty natural gas produced from the leased area in kind. The state's royalty natural gas delivered in kind shall be delivered to the state at the lease or unit area, or other place mutually agreed to by the state and the lessee, and must be delivered to the state or other entity designated by the state.

(b) Royalty natural gas delivered in kind must be delivered in good and merchantable condition, of pipeline quality, and free and clear of all lease expenses (and any portion of those expenses incurred away from the leased area), including, but not limited to, expenses for separating, cleaning, dehydration, gathering, saltwater disposal, compression, processing and preparing the natural gas for transportation off the leased area.

(c) After having given notice of its intention to take, or after having taken its royalty natural gas in kind, the state, at its option and upon 90 days notice to the lessee, may elect to receive a different portion or none of its royalty in kind. If, under federal regulations, the taking of royalty natural gas in value by the state creates a supplier-purchaser relationship, the lessee hereby waives its right to continue to receive royalty natural gas under that relationship, and further agrees that it will require any purchasers of the royalty natural gas likewise to waive any supplier-purchaser rights.

(d) The lessee shall furnish storage for royalty natural gas produced from the lease or unit area to the same extent that the lessee provides storage for the lessee's share of natural gas. The lessee shall not be liable for the loss or destruction of stored natural gas from causes beyond the lessee's reasonable control.

(e) If a state royalty purchaser refuses or for any reason fails to take delivery of natural gas, or in an emergency, and with as much notice to the lessee as is practical or reasonable under the circumstances, the state may elect without penalty to underlift for up to six months all or a portion of the state's royalty natural gas which otherwise would be produced from the lease or unit area and taken in kind. The state's right to underlift is limited to the portion of royalty natural gas that the royalty purchaser refused or failed to take delivery of, or the portion necessary to meet the emergency condition. Underlifted natural gas may be recovered by the state at a daily rate not to exceed 10 percent of its royalty interest share of daily production at the time of the underlift recovery.

10. REDUCTION OF ROYALTY. Lessee may request a reduction of royalty in accordance with the applicable statutes and regulations in effect on the date of application for the reduction.

11. RECORDS. The lessee shall keep and have in its possession books and records showing the development and production (including records of development and production expenses) and disposition (including records of sale prices, volumes, and purchasers) of all natural gas produced from the leased area. The lessee shall permit the state or its agents to examine these books and records at all reasonable times. Upon request by the state, the lessee's books and records shall be made available to the state at the state office designated by the state. These books and records of development, production, and disposition must employ methods and techniques that will ensure the most accurate figures reasonably available without requiring the lessee to provide separate meters for each well. The lessee shall use generally accepted accounting procedures consistently applied.

12. PAYMENTS. Payments to the state under this lease must be made payable to the state in the manner directed by the state, and unless otherwise specified, must be tendered to the state at:

\author{
DEPARTMENT OF NATURAL RESOURCES \\ 550 WEST 7TH STREET, SUITE 1410 \\ ANCHORAGE, ALASKA 99501-3561 \\ ATTENTION: FINANICAL SERVICES SECTION
}

or to depository designated by the state with at least 60 days written notice to the lessee.

13. PLAN OF OPERATIONS. (a) This lease is subject to the provisions of 11 AAC 83.158 or 11 AAC 83.346.

(b) No lease operations may be undertaken on the leased area until a plan of operations has been approved by the state. All of the lessee's operations on or in the leased area must be in conformance with the approved plan of operations. Approval by the state of a plan of operations or any modifications to a plan of operations signifies only that the state has no objection to the operations outlined in the plan. The state's approval does not relieve the lessee of its obligation to obtain approvals and permits required by other governmental agencies having regulatory authority over those operations.

(c) Before undertaking operations on privately owned land in the leased area, the lessee shall provide for full payment of all damages sustained by the owner of the surface estate by reason of entering on the land. The lessee may 
satisfy this requirement by either obtaining written consent of the surface owner, or posting a surety bond determined by the director to be sufficient to secure the owner for damages. This requirement applies to all privately owned surface areas regardless of whether the rights in the surface estate devolve from a state or federal conveyance.

(d) If the lessee undertakes any operations on the leased area without having first complied with subparagraph (c) of this section, the director may issue a verbal or written Notice of Cessation notifying the lessee to cease all operations within 24 hours. Upon issuing a Notice of Cessation, the director shall schedule a hearing to determine the amount of surety bond the lessee will be required to post before recommencing operations on the leased area. If the lessee fails to cease all operations as directed, the state may immediately and without further notice revoke the operating permit pending a hearing and a bond determination.

14. PLAN OF DEVELOPMENT. (a) Except as provided in subparagraph (d), below, within 12 months after certification of a well capable of producing natural gas in paying quantities, the lessee shall file two copies of an application for approval by the state of an initial plan of development that must describe the lessee's plans for developing the leased area. No development of the leased area may occur until a plan of development has been approved by the state.

(b) The plan of development must be revised, updated, and submitted to the state for approval annually before or on the anniversary date to the previously approved plan. If no changes from an approved plan are contemplated for the following year, a statement to that effect must be filed for approval in lieu of the required revision and update.

(c) The lessee may, with the approval of the state, subsequently modify an approved plan of development.

(d) If the leased area is committed to a unit agreement, the lessee will not be required to submit a separate lease plan of development for unit activities.

15. INFORMATION ACQUIRED FROM OPERATIONS. (a) Within 30 days following the completion, suspension, operational shut-down or abandonment of each well, the lessee shall file with the state all logs, geological, geophysical, engineering and other technical data, a description of all tests run for each well drilled on the leased area, and a plat showing the exact location of each well. The state may, in its discretion, require the lessee to submit additional data the state determines necessary or waive the requirement to submit data from specified development, service or injection wells.

(b) Any information the lessee files with the state in connection with this lease will be available at all times for use by the state and its agents. The state will keep information confidential as provided in AS 38.05.035(a)(9) and applicable regulations. In order for geological, geophysical, engineering, well and bore hole data, and interpretations of those data filed in compliance with subparagraph (a) of this section, to be held confidential, the lessee must submit the information in compliance with 11 AAC 82.810.

16. DIRECTIONAL DRILLING. This lease may be maintained in effect by directional wells whose bottom hole locations are on or in the leased area but that are drilled from locations on other lands not covered by this lease. In those circumstances, drilling will be considered to have commenced on the leased area when actual drilling is commenced on those other lands for the purpose of directionally drilling into the leased area. Production of natural gas from the leased area through a directional well located on the those other lands, or drilling or reworking of that directional well, will be considered production or drilling or reworking operations on the leased area for all purposes of this lease. Nothing contained in this paragraph is intended or will be construed as a grant to the lessee of any interest, license, easement, or other right in or with respect to the other lands not within the leased area as it is described in Paragraph 1 of this lease.

17. DILIGENCE AND PREVENTION OF WASTE. (a) The lessee shall exercise reasonable diligence in drilling, producing, and operating wells on the leased area unless consent to suspend operations temporarily is granted by the state.

(b) Upon discovery of natural gas on the leased area in quantities that would appear to a reasonable and prudent operator to be sufficient to recover ordinary costs of drilling, completing, and producing an additional well in the same geologic structure at another location on the leased area or an adjacent state shallow natural gas lease held by the lessee with a reasonable profit to the operator, the lessee must drill such well or wells as a reasonable and prudent operator would drill, having due regard for the interest of the state as well as the interest of the lessee.

(c) The lessee shall perform all operations under this lease in a good and workmanlike manner in accordance with the methods and practices set out in the approved plan of operations, with due regard for the prevention of waste of oil, natural gas and the entrance of water to oil and gas-bearing sands or strata to the destruction or injury of those sands or strata, and to the preservation and conservation of the property for future productive operations. The lessee shall carry out at the lessee's expense all orders and requirements of the state relative to the prevention of waste and to the preservation of the leased area. If the lessee fails to carry out these orders, the state will have the right, together with any other available legal recourse, to enter the leased area to repair damage or prevent waste at the lessee's expense.

(d) Before abandoning any well, the lessee shall securely plug or otherwise close the well in a manner satisfactory to the state. 
18. OFFSET WELLS. The lessee shall drill such wells as a reasonable and prudent operator would drill to protect the state from loss by reason of drainage resulting from production on other land. Without limiting foregoing sentence, if natural gas is produced from a well on land not owned by the state or on which the state receives a lower rate of royalty than the rate under this lease, and that well is within 1,500 feet of lands then subject to this lease, and that well produces natural gas for a period of 30 consecutive days in quantities that would appear to a reasonable and prudent operator to be sufficient to recover ordinary costs of drilling, completing, and producing an additional well in the same geological structure at an offset location with a reasonable profit to the operator; and if, after notice to the lessee and an opportunity to be heard, the state finds that production from that well is draining lands then subject to this lease, the lessee shall within 30 days after written demand by the state begin in good faith to diligently prosecute drilling operations for an offset well on the leased area. In lieu of drilling any well required by this paragraph, the lessee may, with the state's consent, compensate the state in full each month for the estimated loss of royalty through drainage in the amount determined by the state.

19. UNITIZATION. (a) The lessee may unite with others, jointly or separately, in collectively adopting and operating under a cooperative or unit agreement for the exploration, development, or operation of the field, or like area or part of the field, or like area that includes or underlies the leased area or any part of the leased area when the state has determined and certified that the cooperative or unit agreement is in the public interest.

(b) Within six months after demand by the state, the lessee agrees to subscribe to a reasonable cooperative or unit agreement that will adequately protect all parties in interest, including the state. The state reserves the right to prescribe such an agreement.

(c) With the consent of the lessee, and if the leased area is committed to a unit agreement approved by the state, the state may establish, alter, change, or revoke drilling, producing, and royalty requirements of this lease as the state determines necessary or proper to secure the proper protection of the public interest.

(d) Except as otherwise provided in this subparagraph, where only a portion of the leased area is committed to a unit agreement approved or prescribed by the state, that commitment constitutes a severance of this lease as to the unitized and nonunitized portions of the leased area. The portion of the leased area not committed to the unit will be treated as a separate and distinct lease having the same effective date and term as this lease and may be maintained only in accordance with the terms and conditions of this lease, statutes, and regulations. Any portion of the leased area not committed to the unit agreement will not be affected by the unitization or pooling of any other portion of the leased area, by operations in the unit, or by suspension approved or ordered for the unit. If the leased area has a well certified as capable of production in paying quantities on it before commitment to a unit agreement, this lease will not be severed. If any portion of this lease is included in a participating area formed under a unit agreement, the entire leased area as it exists at that time will remain committed to the unit and this lease will not be severed.

20. APPORTIONMENT OF ROYALTY FROM APPROVED UNIT. The state's royalty share of the unit production allocated to each separately owned tract shall be regarded as royalty to be distributed to and among, or the proceeds of or paid to, the state, free and clear of all unit expense and free of any lien for it. Under this provision, the state's royalty share of any unit production allocated to the leased area will be regarded as royalty to be distributed to, or the proceeds of it paid to, the state, free and clear of all unit expenses (and any portion of those expenses incurred away from the unit area), including, but not limited to, expenses for separating, cleaning, dehydration, gathering, saltwater disposal, compression, processing and preparing natural gas for transportation off the unit area, and free of any lien for them.

21. INSPECTION. The lessee shall keep open at all reasonable times, for inspection by any duly authorized representative of the state, the leased area, all wells, improvements, machinery, and fixtures on the leased area, and all reports and records relative to operations and surveys or investigations on or with regard to the leased area or under this lease. Upon request, the lessee shall furnish the state with copies of and extracts from any such reports and records.

22. SUSPENSION. The state may from time to time direct or approve in writing suspension of production or other operations under this lease.

23. ASSIGNMENT, PARTITION, AND CONVERSION. (a) This lease, or an interest in this lease, may not be transferred or assigned until a well capable of production of natural gas in paying quantities has been drilled on this lease. Notwithstanding the foregoing restriction, the lessee is not prohibited from entering into a farmout agreement or similar arrangement with a third party under which the third party assists in exploration and development of production from this lease if the agreement or arrangement does not require a payment of consideration by the third party to the lessee, except that the lessee may retain an overriding royalty interest in this lease or may retain a net profit or other production payment.

(b) Subject to the provisions of subparagraph (a), above, with the approval of the state, this lease, or an interest in this lease may be assigned, subleased, or otherwise transferred to any person or persons qualified to hold a state natural gas lease. No assignment, sublease, or other transfer of an interest in this lease, including assignments of working or royalty 
interests and operating agreements and subleases, will be binding upon the state unless approved by the state. The lessee shall remain liable for all obligations under this lease accruing prior to the approval by the state of any assignment, sublease, or other transfer of an interest in this lease. All provisions of this lease will extend to and be binding upon the heirs, administrators, successors, and assigns of the state and the lessee. Applications for approval of an assignment, sublease, or other transfer must comply with all applicable regulations and must be filed within 90 days after the date of final execution of the instrument of transfer. The state will approve a transfer of an undivided interest in this lease unless the transfer would adversely affect the interests of the state or the application does not comply with applicable regulations. The state will disapprove a transfer of a divided interest in this lease if the transfer covers only a portion of this lease or a separate and distinct zone or geological horizon unless the lessee demonstrates that the proposed transfer of a divided interest is reasonably necessary to accomplish exploration or development of this lease, this lease is committed to an approved unit agreement, this lease is allocated production within an approved participating area, or this lease has a well certified as capable of production in paying quantities. The state will make a written finding stating the reasons for disapproval of a transfer of a divided interest. Where an assignment, sublease, or other transfer is made of all or a part of the lessee's interest in a portion of the leased area, this lease may, at the option of the state or upon request of the transferee and with the approval of the state, be severed, and a separate and distinct lease having the same effective date and terms as this lease will be issued to the transferee.

24. SURRENDER. The lessee at any time may file with the state a written surrender of all rights under this lease or any portion of the leased area comprising one or more legal subdivisions or, with the consent of the state, any separate and distinct zone or geological horizon underlying the leased area or one or more legal subdivisions of the leased area. That surrender will be effective as of the date of filing, subject to the continued obligations of the lessee and its surety to make payment of all accrued royalties and to place all wells and surface facilities on the surrendered land or in the surrendered zones or horizons in a condition satisfactory to the state for suspension or abandonment.

25. DEFAULT AND TERMINATION; CANCELLATION. (a) The lessee's failure to timely perform any obligation under this lease or to otherwise comply with any express or implied provision of this lease is a default of the lessee's obligations under this lease. If the director determines the lessee has defaulted on any obligation under this lease, and the default continues for 60 days after the lessee receives written notice from the state (except for a provision that, by its terms, provides for automatic termination), the director may terminate the lease by either:

(1) mailing written notice of termination to the lessee if there is no well on the leased area that has been determined under 11 AAC 83.361 to be capable of producing natural gas in paying quantities; or

(2) instituting a judicial proceeding to terminate the lease if there is a well on the leased area that has been determined under 11 AAC 83.361 to be capable of producing natural gas in paying quantities.

(b) The state may cancel this lease at any time after the state has suspended or prohibited operations under this lease continuously for a period of five years (or a lesser period upon request of the lessee) and state determines, after notice and a reasonable opportunity to be heard, that:

(1) continued operations under this lease threaten to cause serious harm or damage to biological resources, mineral resources, property or the environment (including the human environment);

(2) the threat of harm or damage will likely not cease or decrease to an acceptable extent within a reasonable period of time; and

(3) the advantages of cancellation outweigh the advantages of continuing this lease in effect.

(cc) Termination or cancellation of the lease under this section does not release the lessee from any liability for abandonment or clean-up costs or damages incurred by the lessee to restore the leased area or to plug and abandon any well or wells and remove personal property from the lease within a reasonable time.

26. RIGHTS UPON TERMINATION. Upon the expiration, termination or cancellation of this lease as to all or any portion of the leased area, the lessee will have the right to remove from the leased area or portion of the leased area all machinery, equipment, tools, and materials. This right does not include removal of property or improvements needed for producing natural gas wells from well bores capable of producing natural gas in paying quantities at the time of expiration, termination or cancellation of this lease. This right will last for one year from the date of expiration, termination or cancellation. Upon the expiration of that period or extension of that period, any machinery, equipment, tools, and materials that the lessee has not removed from the leased area or portion of the leased area become the state's property. The lessee shall, however, remove any and all such property or improvements when directed by the state. If the lessee does not remove the property or improvements when directed, the state may remove them at the lessee's expense. Subject to the above conditions, the lessee shall return the leased area or those portions of the leased area in a condition satisfactory to the state.

27. DAMAGES AND INDEMNIFICATION. (a) The lessee shall indemnify the state for, and hold it harmless from, any claims, demands, liabilities, and expenses, including claims for loss or damage to property or injury to any person caused 
by or resulting from any act or omission committed under this lease by or on behalf of the lessee arising from or in connection with such damages. The lessee is not responsible to the state under this subparagraph for any loss, damage, or injury caused by or resulting from the sole negligence of the state.

(b) The lessee expressly waives any defense to an action for breach of a provision of this lease or for damages resulting from an oil spill, a well blow out, or other harm to the environment that is based on an act or omission committed by an independent contractor in the lessee's employ. The lessee expressly agrees to assume responsibility for all actions of its independent contractors.

28. BONDS. (a) If required by the state, the lessee shall furnish a bond prior to the issuance of this lease in an amount equal to at least $\$ 5$ per acre or fraction of an acre contained in the leased area, but no less than $\$ 10,000$, and must maintain that bond as long as required by the state.

(b) The lessee may, in lieu of the bond required under subparagraph (a), above, furnish and maintain a statewide bond in accordance with applicable regulations.

(c) The state may, after notice to the lessee and a reasonable opportunity to be heard, require a bond in a reasonable amount greater than the amount specified in subparagraph (a), above, where a greater amount is justified by the nature of the surface and its uses and the degree of risk involved in the types of operations being or to be carried out under this lease. A statewide bond will not satisfy any requirement of a bond imposed under this subparagraph, but will be considered by the state in determining the need for and the amount of any additional bond under this subparagraph.

(d) If the leased area is committed in whole or in part to a cooperative or unit agreement approved or prescribed by the state, and the unit operator furnishes a statewide bond, the lessee need not maintain any bond with respect to the portion of the leased area committed to the cooperative or unit agreement.

29. AUTHORIZED REPRESENTATIVES. The Director of the Division of Oil and Gas, Department of Natural Resources, and the person executing this lease on behalf of the lessee shall be the authorized representatives for their respective principals for the purposes of administering this lease. The state or the lessee may change the designation of its authorized representative or the address to which notices to that representative are to be sent by a notice given in accordance with Paragraph 30, below. Where activities under a plan of operations are underway, the lessee shall also designate, pursuant to a notice under Paragraph 30 , below, by name, job title, and address, an agent who will be present in the state during all lease activities.

30. NOTICES; PROTEST. (a) Notices required or permitted under this lease must be by electronic media producing a permanent record or in writing and must be given personally or by registered or certified mail, return receipt requested, addressed as follows:

TO THE STATE:

DIRECTOR, DIVISION OF OIL AND GAS DEPARTMENT OF NATURAL RESOURCES

550 W. 7TH AVENUE, SUITE 800

ANCHORAGE, ALASKA 99501-3560

TO THE LESSEE:

(b) Any notice given under this paragraph will be effective when delivered to the above-authorized representative.

(c) A lessee who wishes to protest the amount of money due the state under this lease or any action of the state regarding a provision of this lease must file a written appeal with the Division of Oil and Gas under 11 AAC $02.010-11$ AAC 02.080 .

31. STATUTES AND REGULATIONS. This lease is subject to all applicable state and federal statutes, rules and regulations in effect on the effective date of this lease, and to all statutes and regulations placed in effect after the effective date of this lease. A reference to a statute or regulation in this lease includes any change in that statute or regulation whether by amendment, repeal and replacement, or other means. This lease does not limit the power of the state or the United States of America to enact and enforce legislation or to promulgate and enforce regulations affecting, directly or indirectly, the 
activities of the lessee or its agents in connection with this lease or the value of the interest held under this lease. In case of conflicting provisions, statutes and regulations take precedence over this lease.

32. APPEALS The lessee shall appeal decisions of the commissioner related to this lease in accordance with 11 AAC 02.

33. INTERPRETATION This lease is to be interpreted in accordance with the rules applicable to the interpretation of contracts made in the State of Alaska. The paragraph headings are not part of this lease and are inserted only for convenience. The state and the lessee expressly agree that the law of the State of Alaska will apply in any judicial proceeding affecting this lease.

34. INTEREST IN REAL PROPERTY. It is the intention of the parties that the rights granted to the lessee by this lease constitute an interest in real property in the leased area.

35. WAIVER OF CONDITIONS The state reserves the right to waive any breach of a provision of this lease, but any such waiver extends only to the particular breach so waived and does not limit the rights of the state with respect to any future breach: nor will the waiver of a particular breach prevent cancellation of this lease for any other cause or for the same cause occurring at another time. Notwithstanding the foregoing, the state will not be deemed to have waived a provision of this lease unless it does so in writing.

36. SEVERABILITY. If it is finally determined in any judicial proceeding that any provision of this lease is invalid, the state and the lessee may jointly agree by a written amendment to this lease that, in consideration of the provisions in that written amendment, the invalid portion will be treated as severed from this lease and that the remainder of this lease, as amended, will remain in effect.

37. LOCAL HIRE To the extent they are available and qualified, the lessee is encouraged to employ local and Alaska residents and contractors for work performed on the leased area.

38. CONDITIONAL LEASE If all or a part of the leased area is land that has been selected by the state under laws of the United States granting lands to the state, but the land has not been patented to the state by the United States, then this lease is a conditional lease as provided by law until the patent becomes effective. If for any reason the selection is not finally approved, or the patent does not become effective, any rental, or royalty payments made to the state under this lease will not be refunded.

39. NONDISCRIMINATION The lessee and its contractors and subcontractors may not discriminate against any employee or applicant because of race, religion, marital status, change in marital status, pregnancy, parenthood, physical handicap, color, sex, age, or national origin as set out in AS 18.80.220. The lessee and its contractors and subcontractors must, on beginning any operations under this lease, post in a conspicuous place notices setting out this nondiscrimination provision.

40. DEFINITIONS All words and phrases used in this lease are to be interpreted where possible under AS 01.10.040. Notwithstanding the foregoing, the following words have the following meanings unless the context unavoidably requires otherwise:

(1) "drilling" means the act of boring a hole to reach a proposed bottom hole location through which natural gas may be produced if encountered in paying quantities, including redrilling, sidetracking, deepening or other means necessary to reach the proposed bottom hole location, and testing, logging, plugging, and other operations necessary and incidental to the actual boring of the hole;

(2) "force majeure" means war, riots, acts of God, unusually severe weather, or any other cause beyond the lessee's reasonable ability to foresee and control. It includes operational failure of existing transportation facilities and delays caused by judicial decisions or lack of them.

(3) "natural gas" means all hydrocarbons gaseous at standard temperature and pressure, including gas associated with coal deposits, and all other hydrocarbons produced incidental to production by ordinary methods that are not defined in this lease as oil;

(4) "oil" means crude petroleum oil and other hydrocarbons, regardless of gravity, that are produced in liquid form by ordinary production methods, including liquid hydrocarbons known as distillate or condensate recovered by separation from gas other than at a gas processing plant:

(5) "paying quantities" means quantities sufficient to yield a return in excess of operating costs, even if drilling and equipment costs may never be repaid and the undertaking considered as a whole may ultimately result in a loss: quantities 
are insufficient to yield a return in excess of operating costs unless those quantities, not considering the costs of transportation and marketing, will produce sufficient revenue to induce a prudent operator to produce those quantities; and

(6) "reworking operations" means all operations designed to secure, restore, or improve production through some use of a hole previously drilled, including, but not limited to, mechanical or chemical treatment of any horizon, and plugging back to test higher strata;

41. EFFECTIVE DATE. This lease takes effect on

BY EXECUTING THIS LEASE, the state as lessor and the lessee agree to be bound by its provisions.

\section{STATE OF ALASKA}

By:

Kenneth A. Boyd

Director, Division of Oil and Gas

$\begin{array}{ll}\text { STATE OF ALASKA } & \text { ) ss. } \\ \text { Third Judicial District } & \text { ) }\end{array}$

On

, before me appeared Kenneth A. Boyd of the Division of Oil and Gas of the State of Alaska, Department of Natural Resources, and who executed this lease and acknowledged voluntarily signing it on behalf of the State of Alaska as lessor.

Notary public in and for the State of Alaska

My commission expires

\section{LESSEE:}

Signature:

Printed Name/Title:

INSERT NOTARY ACKNOWLEDGMENT OF LESSEE'S SIGNATURE HERE. 
LESSEE:

Signature:

Printed Name/Title:

INSERT NOTARY ACKNOWLEDGMENT OF LESSEE'S SIGNATURE HERE.

LESSEE:

Signature:

Printed Name/Title:

INSERT NOTARY ACKNOWLEDGMENT OF LESSEE'S SIGNATURE HERE. 


\section{Exhibit B}

\section{Illustrative Calculation of Value under Paragraph 7 \\ (For illustrative Purposes Only)}

\section{Royalty Value gas}

Assume for the purposes of calculating Royalty Valuegas (RVG) that:

1) The lessee owns an 80 percent interest in seven shallow gas leases in the Broken Bone Unit near the community of Cecily, Alaska. The lessee developed the unit to supplement the energy requirements for nearby Stone Quarry, a small construction marble and specialty stone cutting operation owned by the lessee.

2) The production month is March 1999.

3) Platt's Oilgram Price Report provides a high and low product price assessment for every trading day for West Coast Waterborne Gasoil expressed in dollars per barrel. Table 1 illustrates the calculation of the average price assessment of West Coast Waterborne Gasoil for the production month of March 1999. The high and low product price assessments are averaged for each trading day and the sum of these averages are divided by the number of trading days in the calendar month to calculate the monthly average product price assessment. This value is rounded to the nearest cent. In Table 1 the average price assessment for West Coast Waterborne Gasoil for March 1999 is $\$ 19.46$.

4) To calculate the Minimum Value of Gas (MVG) of the Transaction Value of Gas (TVG) per Mcf, the lessee has to evaluate each disposition its gas delivered during the production month. For the purposes of this illustration, assume that the lessee's March 1999 transactions occurred as follows:

Table 1: Lessee Oil Dispositions in March 1999

\section{Transaction and Point of Sale}

1. Stone Quarry - Delivered

2. The lessee sells gas to the Island 110 Mcf School District - Delivered

3. The lessee sells gas to the Cecily Gas and Electric Company - Sold at the Unit.

\section{March Delivery Volume}

108,500 Mcf

$6,250 \mathrm{Mcf}$

\section{Lessee's Contract Price Term}

Lessee's partners in the quarry have agreed to a transfer price of $\$ 1.00$ per Mcf.

Gas supplied and metered at the Cecily Elementary School under a one-year contract for $\$ 3.50$ per Mcf.

Lessee supplies gas to the Cecily Gas and Electric Company under a five-year contract for 100,000 Mcf supplied as needed. Price is based on $\$ 1.85$ per Mcf adjusted by an oil price index with a premium required for volumes in excess of 500 Mcf per month.

Notes on Table 1:

Transaction 1 This is a non-arm's length transaction. The lessee and its partners in Stone Quarry have agreed to a price of $\$ 1.00$ per Mcf for as long as Stone Quarry is in operation. There are separate supply agreements between Stone Quarry and the other owners in the Broken Bone Unit but they are not relevant to the calculation of the lessee's TVG for this transaction.

Transaction 2 The lessee sells gas to the Island School District to supply Cecily Elementary School. The school pays $\$ 3.50$ per Mcf at the meter at the school. The lessee pays a \$2.00 per Mcf Transportation charge to the Cecily Gas and Electric Company to transport the gas to the school. The lessee deducts this charge in its calculation of TVG.

Transaction 3 The lessee has a five-year contract with the Cecily Gas and Electric Company. Under the agreement the lessee will supply up to 100,000 Mcf to the utility for $\$ 1.85$ per Mcf adjusted quarterly by an oil price index. If the utility uses more than $500 \mathrm{Mcf}$ in any month, it must pay the lessee a 15 percent premium for the volume in excess of 500 Mcf. In March 1999, the utility paid $\$ 1.80$ per Mcf on average for its volumes. This is the price reported by the lessee as its TVG.

MVG is calculated by applying the formula in Paragraph 7(A)(I) using the WC Gasoil March from Table 2.

$$
\begin{aligned}
\mathrm{MVG} & =\$ 1.40 / \mathrm{Mcf} X(\mathrm{WC} \text { Gasoillarch } / \$ 22.50) \\
\mathrm{MVG} & =\$ 1.40 / \mathrm{Mcf} \times(\$ 19.46 / \$ 22.50) \\
& =\$ 1.21084 / \mathrm{Mcf}=\$ 1.21 / \mathrm{Mcf}
\end{aligned}
$$


Table 3 illustrates how the higher of TVG and MVG are calculated for each of the lessee's transactions. TVG from the information about the lessee's transactions in Table 1 is compared to MVG for each transaction. If TVG is not known at the time the royalty payment is due, the lessee must estimate his RVG on the basis of MVG and submit a revision later to account for TVG, if higher than MVG.

- RVG is the volume-weighted average of the higher of MVG and TVG for each transaction, i.e., the higher of MVG and TVG for each transaction is multiplied by the volume delivered during the production month for each transaction. The products of the MVG or TVG times the volumes for each transaction are summed and divided by the lessee's total volume sold to determine RVG. RVG is multiplied by the royalty volume produced by the lessee. The royalty payment calculation appears at the bottom of Table 3.

Table 2: Calculation of the Monthly Average West Coast Waterborne Gasoil Price

\begin{tabular}{|c|c|c|c|}
\hline \multicolumn{4}{|c|}{ March 1999} \\
\hline $\begin{array}{c}\text { Effective } \\
\text { Date }\end{array}$ & $\begin{array}{l}\text { ANS West } \\
\text { Coast Low }\end{array}$ & $\begin{array}{l}\text { ANS West } \\
\text { Coast High }\end{array}$ & $\begin{array}{c}\text { ANS WC } \\
\text { Daily } \\
\text { Average }\end{array}$ \\
\hline 03/01/99 & $\$ 15.00$ & $\$ 15.50$ & $\$ 15.250$ \\
\hline 03/02/99 & $\$ 15.75$ & $\$ 16.25$ & $\$ 16.000$ \\
\hline 03/03/99 & $\$ 15.75$ & $\$ 16.25$ & $\$ 16.000$ \\
\hline 03/04/99 & $\$ 16.50$ & $\$ 17.25$ & $\$ 16.875$ \\
\hline 03/05/99 & $\$ 17.50$ & $\$ 18.25$ & $\$ 17.875$ \\
\hline 03/08/99 & $\$ 19.00$ & $\$ 19.50$ & $\$ 19.250$ \\
\hline 03/09/99 & $\$ 20.00$ & $\$ 21.00$ & $\$ 20.500$ \\
\hline 03/10/99 & $\$ 19.50$ & $\$ 20.25$ & $\$ 19.875$ \\
\hline 03/11/99 & $\$ 19.50$ & $\$ 20.25$ & $\$ 19.875$ \\
\hline 03/12/99 & $\$ 19.00$ & $\$ 20.00$ & $\$ 19.500$ \\
\hline $03 / 15 / 99$ & $\$ 19.00$ & $\$ 20.00$ & $\$ 19.500$ \\
\hline 03/16/99 & $\$ 18.75$ & $\$ 19.25$ & $\$ 19.000$ \\
\hline 03/17/99 & $\$ 18.75$ & $\$ 19.25$ & $\$ 19.000$ \\
\hline 03/18/99 & $\$ 19.50$ & $\$ 20.25$ & $\$ 19.875$ \\
\hline 03/19/99 & $\$ 20.00$ & $\$ 20.75$ & $\$ 20.375$ \\
\hline 03/22/99 & $\$ 20.00$ & $\$ 20.75$ & $\$ 20.375$ \\
\hline 03/23/99 & $\$ 21.00$ & $\$ 22.00$ & $\$ 21.500$ \\
\hline 03/24/99 & $\$ 20.50$ & $\$ 21.50$ & $\$ 21.000$ \\
\hline 03/25/99 & $\$ 20.50$ & $\$ 21.50$ & $\$ 21.000$ \\
\hline 03/26/99 & $\$ 21.00$ & $\$ 22.00$ & $\$ 21.500$ \\
\hline 03/29/99 & $\$ 21.50$ & $\$ 22.50$ & $\$ 22.000$ \\
\hline 03/30/99 & $\$ 21.50$ & $\$ 22.50$ & $\$ 22.000$ \\
\hline 03/31/99 & $\$ 22.75$ & $\$ 24.00$ & $\$ 23.375$ \\
\hline \multicolumn{3}{|c|}{ Sum of daily averages $=$} & $\$ 451.500$ \\
\hline \multicolumn{3}{|c|}{ Monthly Average $=\$ 451.500 / 23=$} & $\$ 19.460$ \\
\hline \multicolumn{3}{|c|}{ WC Gasoil March $=$} & $\$ 19.46$ \\
\hline
\end{tabular}

1/ The value for WC Gasoil is rounded to the nearest cent before it is included in subsequent calculations.

Source: "Platt's Oilgram Price Report." Published by Standard and Poor's McGraw-Hill Companies. 
Table 3: Calculation of Royalty Value of $G_{\text {as }}$ (RVG)

Based on the Higher-of the Minimum Value of Gas (MVG) and the Transaction Value of Gas (TVG)

Transaction

1. Supply to Stone Quarry

2. Gecily School District Contract

2. Gecily Village Gas and Electric

$\begin{array}{cc}\begin{array}{c}\text { TVG } \\ \text { (Contract, } \\ \text { Exchange or } \\ \text { Internal }\end{array} & \begin{array}{c}\text { MVG } \\ \text { Paragraph } \\ \mathbf{7 ( A ) ( 1 )}\end{array} \\ \text { Transfer Price) } & \\ \$ 1.00 & \$ 1.21 \\ \$ 1.50(=\$ 3.50-\$ 2.00) & \$ 1.21 \\ \$ 1.80 & \$ 1.21\end{array}$

Higher-of
TVG
or
MVG

Volume

(Mct)

\begin{tabular}{lrr}
$\$ 1.21$ & 108,500 & $\$ 131,285.00$ \\
$\$ 1.50$ & 110 & $\$ 165.00$ \\
$\$ 1.80$ & $\mathbf{2 , 2 5 0}$ & $\$ 4,050.00$ \\
\cline { 2 - 3 } & $\mathbf{1 1 0 . 8 6 0}$ & $\$ 135,500.00$
\end{tabular}

$\mathbf{5 1 3 5 , 5 0 0 / 1 1 0 , 8 6 0 =}$

$\$ 1.22226$

$A \vee G=$

$\$ 1.221$

1/ The value for RVG is rounded to the nearest cent before it is included in subsequent calculations.

The Lessee's royalty payment is calculated as follows:

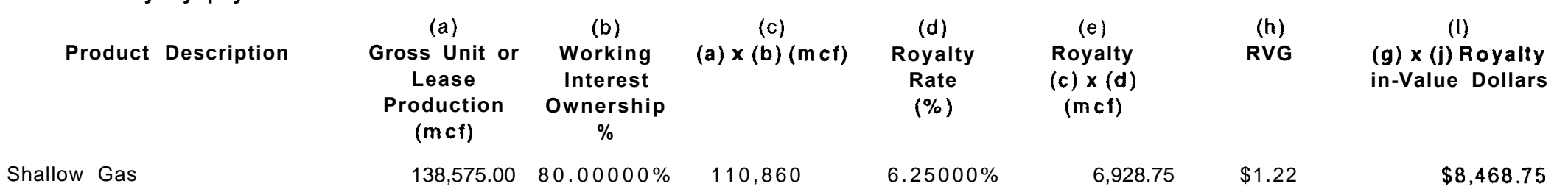




\section{QUALIFYING TO APPLY FOR, OBTAIN, OR TRANSFER AN INTEREST IN A PERMIT OR LEASE RELATING TO OIL AND GAS IN ALASKA}

\section{WHO MUST FILE}

Every individual, association or partnership, corporation, or person authorized to act on behalf of another party must qualify with the Division of Oil and Gas prior to bidding for lease tracts or applying for, obtaining, or transferring interest in a permit or lease issued under AS 38.05135 38.05184.

\section{WHERE TO FILE}

Address any required information or inquiries regarding qualifications to Judy Stanek, State of Alaska, Department of Natural Resources, Division of Oil and Gas, 550 West 7'" Avenue, Suite 800, Anchorage, Alaska 99503-3510.

\section{HOW TO FILE}

The following is a list of the information and documents required when qualifying under 11 AAC 82.200 -- 11 AAC 82.205. Information and documents which have been filed previously and are still current may be sufficient to qualify individuals or other entities.

\section{A. INDIVIDUALS}

Individuals must submit a signed, dated statement including the applicant's name, address, telephone number, preferably notarized, attesting that: the individual has reached the age of majority. (In Alaska the age of majority is 18 years, except for those who are automatically emancipated earlier by marriage or those emancipated by court order.)

A form for submitting an individual's statement of qualifications is attached. Additional forms may be obtained from the division upon request, or a statement including the necessary information may be composed and submitted by an individual.

Any legal representative, guardian, or trustee for an individual must submit a certified copy of the court order authorizing them to act in that capacity and to fulfill, on behalf of the individual, all obligations arising under the lease or permit, and their signed statement as to the citizenship and age of the individual and themselves.

Agents for an individual must submit an original or a certified copy of the notarized power of attorney instrument authorizing the agent to act on behalf of the individual. 
Page 2

\section{B. CORPORATIONS}

Corporations must submit:

1) the current address of the corporation,

2) a list of the individuals authorized to act on its behalf with respect to the mineral specified in the permit or lease,

3) an original or certified copy of a notarized power of attorney authorizing any agent who is not a current officer but who has been authorized by the corporation to act on its behalf with respect to the mineral specified in the permit or lease,

4) a Certificate of Compliance for those corporations qualified to do business in Alaska, or

5) if filing for the first time, either a Certificate of Incorporation from those corporations which have been incorporated in the State of Alaska (also known as "domestic" corporations), or a Certificate of Authority from those corporations which have been incorporated outside the State of Alaska (also known as "foreign" corporations).

These documents can be obtained from:

Alaska Department of Community and Economic Development Division of Banking, Securities and Corporations

Attention: Corporations Section

9th Floor, State Office Building

P. 0.110808

Juneau, AK 9981 l-0808

(907) 4652530

-or-

Alaska Department of Community and Economic Development Division of Banking, Securities and Corporations

3601 "C" Street, Suite 724

Anchorage, AK 99503

(907) 269-8140

Inquiries about incorporating in Alaska or qualifying a foreign corporation to do business in Alaska should be addressed to personnel at either of the above addresses. 
Page 3

C. UNINCORPORATED ASSOCIATIONS

Unincorporated Associations must submit:

1) a statement describing the business relationships between members of the association or partnership,

2) a statement of qualifications for each member of the association or partnership (outlines in Section A in this letter), -and/orif some or all of the members are incorporated entities, all information required for corporations (described in Section B of this letter ) must also be submitted, and

3) in the case of an agent acting on behalf of an individual, an original or certified copy of a notarized power of attorney defining the agent's authority to sign with respect to the mineral specified in the permit or lease on behalf of the partnership or association.

If still current, material previously filed with the department satisfying all or part of the requirements of this section may be incorporated in an application by appropriate reference together with a statement as to any material changes or amendments. (Eff. 9/5/74, Register 51; am 7/22/79, Register 71; am 3/27/82, Register 81; am 3/18/83, Register 85; am 7/I/89, Register 110)

\section{SOURCES}

11 AAC 82.200

11 AAC 82.205

AS 38.05.020

AS 38.05.145(a)

\section{FURTHER INFORMATION}

Should you have any further questions regarding qualifying for Alaska oil and gas leases, please contact Judy Stanek, Alaska Division of Oil and Gas, 550 West 7'h Ave, Suite 800, Anchorage, Alaska 99501-3510, phone number (907) 269-8816. 
Department of Natural Resources

Division of Oil and Gas

\section{STATEMENT OF QUALIFICATION}

I, certify, that as an applicant for an interest in oil and (typed or printed name)

gas resources in the State of Alaska, I am the age of majority. (The age of majority in Alaska is 18 years, except for those who are automatically emancipated earlier by marriage or those emancipated by court order.)

Date

Signature

Printed Name

Street or P. 0. Box

City, State, Zip Code

Telephone Number

Social Security Number *

* Provision of social security number is voluntary, used solely to prevent duplication of records and assure more accurate service to our customers.

THE UNITED STATES OF AMERICA )

SS.

STATE OF

Onthis day of 19 ,beforeme, the undersigned, aNotary Public duly commissioned and sworn, appeared , personally known to me, or proved to me on the basis of satisfactory evidence, to be the person whose name is subscribed to the within Statement.

WITNESS my hand and official seal.

Notary Public in and for the State of My commission expires 


\section{Shallow Natural Gas Lease Application Filing - 2-29-2000, 8:30 am}

The priority number is the order in which applications will be adjudicated.

\begin{tabular}{|c|c|c|c|}
\hline Applicant & $\begin{array}{l}\text { Number of } \\
\text { Applications }\end{array}$ & $\begin{array}{c}\text { Applicant } \\
\text { No. } \\
\end{array}$ & Priority No. \\
\hline Hollmann, Nancy A. & 8 & 26 & 1 \\
\hline Hollman, Elisabeth M. & 8 & 27 & 2 \\
\hline Cominco Alaska Incorporated & 4 & 3 & 3 \\
\hline Lapp Resources Inc. & 8 & 9 & 4 \\
\hline Mills, Paula J. & 8 & 31 & 5 \\
\hline Ocean Energy Resources, Inc. (Hank Wood, Agent) & 9 & 24 & 6 \\
\hline Teich, John C. & 9 & 22 & 7 \\
\hline Orell, Elizabeth A. & 8 & 19 & 8 \\
\hline Carlton, Dennis R. & 8 & 32 & $\overline{9}$ \\
\hline Collins, Kevin R. & 8 & 33 & 10 \\
\hline Evergreen Resources Inc. & 9 & 36 & 11 \\
\hline Orell, Jennifer & 8 & 20 & 12 \\
\hline Growth Resources, Inc. & 3 & 8 & 13 \\
\hline Thomas, Lowell R. & 8 & 29 & 14 \\
\hline Murray, Dennis A. & 9 & 16 & 15 \\
\hline Lappi, Linda & 8 & 11 & $\overline{16}$ \\
\hline Lappi, Troy & 8 & 12 & 17 \\
\hline Schlenker, Kenneth A. & 8 & 21 & 18 \\
\hline Emery, Pamela J. & 8 & 28 & 19 \\
\hline Hollmann, Ronald D. & 8 & 35 & 20 \\
\hline Latchem, Raymond R. & 5 & 14 & 21 \\
\hline Hollman, John P. & 8 & 25 & 22 \\
\hline GRI, Inc. & 6 & 7 & 23 \\
\hline Sexton, Mark S. & 8 & 34 & 24 \\
\hline Latchem, Edna A. & 2 & 13 & 25 \\
\hline Bradshaw, Caroline O. & 8 & 1 & 26 \\
\hline Williams, Ted H. & 7 & 23 & 27 \\
\hline Northern Eclipse, LLC. & 2 & 18 & 28 \\
\hline Bradshaw, Kory & 8 & 2 & 29 \\
\hline Latchem, Shannon G. & 10 & 15 & 30 \\
\hline Birkholt, Franklin A. & 8 & 30 & 31 \\
\hline Fulton, William M. & 6 & 6 & 32 \\
\hline Lappi, Cory & 8 & 10 & 33 \\
\hline Fromson, Paul & 10 & 5 & 34 \\
\hline Fitzpatrick, Karen & 8 & 4 & 35 \\
\hline NANA Development Corporation & 4 & 17 & 36 \\
\hline
\end{tabular}




\section{STATE LAND APPLIED FOR UNDER SHALLOW NATURAL GAS LEASING PROGRAM}

Applicant

Northern Eclipse, LLC

Northern Eclipse, LLC

Northern Eclipse, LLC

Northern Eclipse, LLC

Northern Eclipse, LLC

Northern Eclipse, LLC

Northern Eclipse, LLC

Northern Eclipse, LLC

Northern Eclipse, LLC

Northern Eclipse, LLC

Raymond R. Latchem

Raymond R. Latchem

Raymond R. Latchem

Raymond R. Latchem

Northern Eclipse, LLC

Raymond R. Latchem

Northern Eclipse, LLC

Raymond R. Latchem

Northern Eclipse, LLC

Raymond R. Latchem

Northern Eclipse, LLC

Raymond R. Latchem

Northern Eclipse, LLC

Northern Eclipse, LLC

Raymond R. Latchem

Northern Eclipse, LLC

Northern Eclipse, LLC

Caroline O. Bradshaw

Caroline O. Bradshaw

Caroline O. Bradshaw

Caroline O. Bradshaw

Caroline O. Bradshaw

Caroline O. Bradshaw

Caroline O. Bradshaw

Caroline O. Bradshaw

Caroline O. Bradshaw

Caroline O. Bradshaw

Caroline O. Bradshaw

Caroline O. Bradshaw

Caroline O. Bradshaw

Caroline O. Bradshaw

Caroline O. Bradshaw

Caroline O. Bradshaw

Caroline O. Bradshaw

Caroline O. Bradshaw

Caroline O. Bradshaw

Caroline O. Bradshaw

Caroline O. Bradshaw

Caroline O. Bradshaw

Caroline O. Bradshaw

Caroline O. Bradshaw

\begin{tabular}{|c|c|c|c|c|}
\hline $\mathbf{M}$ & $T$ & $\mathbf{R}$ & Section & Priority \\
\hline FSE & 1 & 1 & 36 & 28 \\
\hline FSE & 2 & 1 & 1 & 28 \\
\hline FSE & 2 & 2 & 6 & 28 \\
\hline FSE & 2 & 2 & 7 & 28 \\
\hline FSE & 2 & 2 & 8 & 28 \\
\hline FSE & 2 & 2 & 16 & 28 \\
\hline FSE & 2 & 2 & 17 & 28 \\
\hline FSE & 2 & 2 & 18 & 28 \\
\hline FSE & 2 & 2 & 21 & 28 \\
\hline FSE & 2 & 2 & 36 & 28 \\
\hline FSE & 2 & 3 & 21 & 21 \\
\hline FSE & 2 & 3 & 28 & 21 \\
\hline FSE & 2 & 3 & 29 & 21 \\
\hline FSE & 2 & 3 & 30 & 21 \\
\hline FSE & 2 & 3 & 31 & 28 \\
\hline FSE & 2 & 3 & 31 & 21 \\
\hline FSE & 2 & 3 & 32 & 28 \\
\hline FSE & 2 & 3 & 32 & 21 \\
\hline FSE & 3 & 3 & 5 & 28 \\
\hline FSE & 3 & 3 & 5 & 21 \\
\hline FSE & 3 & 3 & 6 & 28 \\
\hline FSE & 3 & 3 & 6 & 21 \\
\hline FSE & 3 & 3 & 7 & 28 \\
\hline FSE & 3 & 3 & 8 & 28 \\
\hline FSE & 3 & 3 & 8 & 21 \\
\hline FSE & 3 & 3 & 17 & 28 \\
\hline FSE & 3 & 3 & 18 & 28 \\
\hline FSE & 7 & 3 & 1 & 26 \\
\hline FSE & 7 & 3 & 2 & 26 \\
\hline FSE & 7 & 3 & 3 & 26 \\
\hline FSE & 7 & 3 & 4 & 26 \\
\hline FSE & 7 & 3 & 5 & 26 \\
\hline FSE & 7 & 3 & 6 & 26 \\
\hline FSE & 7 & 3 & 7 & 26 \\
\hline FSE & 7 & 3 & 8 & 26 \\
\hline FSE & 7 & 3 & 9 & 26 \\
\hline FSE & 7 & 3 & 10 & 26 \\
\hline FSE & 7 & 3 & 11 & 26 \\
\hline FSE & 7 & 3 & 12 & 26 \\
\hline FSE & 7 & 3 & 13 & 26 \\
\hline FSE & 7 & 3 & 14 & 26 \\
\hline FSE & 7 & 3 & 15 & 26 \\
\hline FSE & 7 & 3 & 16 & 26 \\
\hline FSE & 7 & 3 & 17 & 26 \\
\hline FSE & 7 & 3 & 18 & 26 \\
\hline FSE & 7 & 3 & 19 & 26 \\
\hline FSE & 7 & 3 & 20 & 26 \\
\hline FSE & 7 & 3 & 21 & 26 \\
\hline FSE & 7 & 3 & 22 & 26 \\
\hline FSE & 7 & 3 & 23 & 26 \\
\hline FSE & 7 & 3 & 24 & 26 \\
\hline
\end{tabular}




\section{STATE LAND APPLIED FOR UNDER SHALLOW NATURAL GAS LEASING PROGRAM}

\section{Applicant}

Caroline O. Bradshaw

Caroline O. Bradshaw

Caroline O. Bradshaw

Caroline O. Bradshaw

Caroline O. Bradshaw

Caroline O. Bradshaw

Caroline O. Bradshaw

Caroline O. Bradshaw

Caroline O. Bradshaw

Caroline O. Bradshaw

Caroline O. Bradshaw

Caroline O. Bradshaw

Caroline O. Bradshaw

Caroline O. Bradshaw

Caroline O. Bradshaw

Caroline O. Bradshaw

Caroline O. Bradshaw

Caroline O. Bradshaw

Caroline O. Bradshaw

Caroline O. Bradshaw

Caroline O. Bradshaw

Caroline O. Bradshaw

Caroline O. Bradshaw

Caroline O. Bradshaw

Caroline O. Bradshaw

Caroline O. Bradshaw

Caroline O. Bradshaw

Caroline O. Bradshaw

Caroline O. Bradshaw

Caroline O. Bradshaw

Caroline O. Bradshaw

Caroline O. Bradshaw

Caroline O. Bradshaw

Caroline O. Bradshaw

Caroline O. Bradshaw

Caroline O. Bradshaw

Caroline O. Bradshaw

Caroline O. Bradshaw

Caroline O. Bradshaw

Caroline O. Bradshaw

Caroline O. Bradshaw

Caroline O. Bradshaw

Caroline O. Bradshaw

Caroline O. Bradshaw

Caroline O. Bradshaw

Caroline O. Bradshaw

Caroline O. Bradshaw

Caroline O. Bradshaw

Kory Bradshaw

Kory Bradshaw

Kory Bradshaw

\begin{tabular}{|c|c|c|c|c|}
\hline $\mathbf{M}$ & $\mathbf{T}$ & $\mathbf{R}$ & Section & Priority \\
\hline FSE & 7 & 3 & 25 & 26 \\
\hline FSE & 7 & 3 & 26 & 26 \\
\hline FSE & 7 & 3 & 27 & 26 \\
\hline FSE & 7 & 3 & 28 & 26 \\
\hline FSE & 7 & 3 & 29 & 26 \\
\hline FSE & 7 & 3 & 30 & 26 \\
\hline FSE & 7 & 3 & 31 & 26 \\
\hline FSE & 7 & 3 & 32 & 26 \\
\hline FSE & 7 & 3 & 33 & 26 \\
\hline FSE & 7 & 3 & 34 & 26 \\
\hline FSE & 7 & 3 & 35 & 26 \\
\hline FSE & 7 & 3 & 36 & 26 \\
\hline FSE & 7 & 4 & 1 & 26 \\
\hline FSE & 7 & 4 & 2 & 26 \\
\hline FSE & 7 & 4 & 3 & 26 \\
\hline FSE & 7 & 4 & 4 & 26 \\
\hline FSE & 7 & 4 & 5 & 26 \\
\hline FSE & 7 & 4 & 6 & 26 \\
\hline FSE & 7 & 4 & 7 & 26 \\
\hline FSE & 7 & 4 & 8 & 26 \\
\hline FSE & 7 & 4 & 9 & 26 \\
\hline FSE & 7 & 4 & 10 & 26 \\
\hline FSE & 7 & 4 & 11 & 26 \\
\hline FSE & 7 & 4 & 12 & 26 \\
\hline FSE & 7 & 4 & 13 & 26 \\
\hline FSE & 7 & 4 & 14 & 26 \\
\hline FSE & 7 & 4 & 15 & 26 \\
\hline FSE & 7 & 4 & 16 & 26 \\
\hline FSE & 7 & 4 & 17 & 26 \\
\hline FSE & 7 & 4 & 18 & 26 \\
\hline FSE & 7 & 4 & 19 & 26 \\
\hline FSE & 7 & 4 & 20 & 26 \\
\hline FSE & 7 & 4 & 21 & 26 \\
\hline FSE & 7 & 4 & 22 & 26 \\
\hline FSE & 7 & 4 & 23 & 26 \\
\hline FSE & 7 & 4 & 24 & 26 \\
\hline FSE & 7 & 4 & 25 & 26 \\
\hline FSE & 7 & 4 & 26 & 26 \\
\hline FSE & 7 & 4 & 27 & 26 \\
\hline FSE & 7 & 4 & 28 & 26 \\
\hline FSE & 7 & 4 & 29 & 26 \\
\hline FSE & 7 & 4 & 30 & 26 \\
\hline FSE & 7 & 4 & 31 & 26 \\
\hline FSE & 7 & 4 & 32 & 26 \\
\hline FSE & 7 & 4 & 33 & 26 \\
\hline FSE & 7 & 4 & 34 & 26 \\
\hline FSE & 7 & 4 & 35 & 26 \\
\hline FSE & 7 & 4 & 36 & 26 \\
\hline FSE & 7 & 5 & 5 & 29 \\
\hline FSE & 7 & 5 & 6 & 29 \\
\hline FSE & 7 & 5 & 7 & 29 \\
\hline
\end{tabular}




\section{STATE LAND APPLIED FOR UNDER SHALLOW NATURAL GAS LEASING PROGRAM}

\begin{tabular}{|c|c|c|c|c|c|}
\hline Applicant & $\mathbf{M}$ & $T$ & $\mathbf{R}$ & Section & Priority \\
\hline Kory Bradshaw & FSE & 7 & 5 & 8 & 29 \\
\hline Kory Bradshaw & FSE & 7 & 5 & 9 & 29 \\
\hline Kory Bradshaw & FSE & 7 & 5 & 15 & 29 \\
\hline Kory Bradshaw & FSE & 7 & 5 & 16 & 29 \\
\hline Kory Bradshaw & FSE & 7 & 5 & 17 & 29 \\
\hline Kory Bradshaw & FSE & 7 & 5 & 18 & 29 \\
\hline Kory Bradshaw & FSE & 7 & 5 & 19 & 29 \\
\hline Kory Bradshaw & FSE & 7 & 5 & 20 & 29 \\
\hline Kory Bradshaw & FSE & 7 & 5 & 21 & 29 \\
\hline Kory Bradshaw & FSE & 7 & 5 & 22 & 29 \\
\hline Kory Bradshaw & FSE & 7 & 5 & 23 & 29 \\
\hline Kory Bradshaw & FSE & 7 & 5 & 24 & 29 \\
\hline Kory Bradshaw & FSE & 7 & 5 & 25 & 29 \\
\hline Kory Bradshaw & FSE & 7 & 5 & 26 & 29 \\
\hline Kory Bradshaw & FSE & 7 & 5 & 27 & 29 \\
\hline Kory Bradshaw & FSE & 7 & 5 & 28 & 29 \\
\hline Kory Bradshaw & FSE & 7 & 5 & 29 & 29 \\
\hline Kory Bradshaw & FSE & 7 & 5 & 30 & 29 \\
\hline Kory Bradshaw & FSE & 7 & 5 & 31 & 29 \\
\hline Kory Bradshaw & FSE & 7 & 5 & 32 & 29 \\
\hline Kory Bradshaw & FSE & 7 & 5 & 33 & 29 \\
\hline Kory Bradshaw & FSE & 7 & 5 & 34 & 29 \\
\hline Kory Bradshaw & FSE & 7 & 5 & 35 & 29 \\
\hline Kory Bradshaw & FSE & 7 & 5 & 36 & 29 \\
\hline Kory Bradshaw & FSE & 7 & 6 & 24 & 29 \\
\hline Kory Bradshaw & FSE & 7 & 6 & 25 & 29 \\
\hline Kory Bradshaw & FSE & 7 & 6 & 26 & 29 \\
\hline Kory Bradshaw & FSE & 7 & 6 & 31 & 29 \\
\hline Kory Bradshaw & FSE & 7 & 6 & 32 & 29 \\
\hline Kory Bradshaw & FSE & 7 & 6 & 33 & 29 \\
\hline Kory Bradshaw & FSE & 7 & 6 & 34 & 29 \\
\hline Kory Bradshaw & FSE & 7 & 6 & 35 & 29 \\
\hline Kory Bradshaw & FSE & 7 & 6 & 36 & 29 \\
\hline Kory Bradshaw & FSE & 8 & 3 & 1 & 29 \\
\hline Kory Bradshaw & FSE & 8 & 3 & 2 & 29 \\
\hline Kory Bradshaw & FSE & 8 & 3 & 3 & 29 \\
\hline Kory Bradshaw & FSE & 8 & 3 & 4 & 29 \\
\hline Kory Bradshaw & FSE & 8 & 3 & 5 & 29 \\
\hline Kory Bradshaw & FSE & 8 & 3 & 6 & 29 \\
\hline Kory Bradshaw & FSE & 8 & 3 & 7 & 29 \\
\hline Kory Bradshaw & FSE & 8 & 3 & 8 & 29 \\
\hline Kory Bradshaw & FSE & 8 & 3 & 9 & 29 \\
\hline Kory Bradshaw & FSE & 8 & 3 & 10 & 29 \\
\hline Kory Bradshaw & FSE & 8 & 3 & 11 & 29 \\
\hline Kory Bradshaw & FSE & 8 & 3 & 12 & 29 \\
\hline Kory Bradshaw & FSE & 8 & 3 & 13 & 29 \\
\hline Kory Bradshaw & FSE & 8 & 3 & 14 & 29 \\
\hline Kory Bradshaw & FSE & 8 & 3 & 15 & 29 \\
\hline Kory Bradshaw & FSE & 8 & 3 & 16 & 29 \\
\hline Kory Bradshaw & FSE & 8 & 3 & 17 & 29 \\
\hline Kory Bradshaw & FSE & 8 & 3 & 18 & 29 \\
\hline
\end{tabular}




\begin{tabular}{|c|c|c|c|c|c|}
\hline Applicant & $\mathbf{M}$ & $\mathbf{T}$ & $\mathbf{R}$ & Section & Priority \\
\hline Kory Bradshaw & FSE & 8 & 3 & 19 & 29 \\
\hline Kory Bradshaw & FSE & 8 & 3 & 20 & 29 \\
\hline Kory Bradshaw & FSE & 8 & 3 & 21 & 29 \\
\hline Kory Bradshaw & FSE & 8 & 3 & 22 & 29 \\
\hline Kory Bradshaw & FSE & 8 & 3 & 23 & 29 \\
\hline Kory Bradshaw & FSE & 8 & 3 & 24 & 29 \\
\hline Kory Bradshaw & FSE & 8 & 3 & 25 & 29 \\
\hline Kory Bradshaw & FSE & 8 & 3 & 26 & 29 \\
\hline Kory Bradshaw & FSE & 8 & 3 & 27 & 29 \\
\hline Kory Bradshaw & FSE & 8 & 3 & 28 & 29 \\
\hline Kory Bradshaw & FSE & 8 & 3 & 29 & 29 \\
\hline Kory Bradshaw & FSE & 8 & 3 & 30 & 29 \\
\hline Kory Bradshaw & FSE & 8 & 3 & 31 & 29 \\
\hline Kory Bradshaw & FSE & 8 & 3 & 32 & 29 \\
\hline Kory Bradshaw & FSE & 8 & 3 & 33 & 29 \\
\hline Kory Bradshaw & FSE & 8 & 3 & 34 & 29 \\
\hline Kory Bradshaw & FSE & 8 & 3 & 35 & 29 \\
\hline Kory Bradshaw & FSE & 8 & 3 & 36 & 29 \\
\hline Elizabeth A. Orell & FSE & 8 & 4 & 1 & 8 \\
\hline Elizabeth A. Orell & FSE & 8 & 4 & 2 & 8 \\
\hline Elizabeth A. Orell & FSE & 8 & 4 & 3 & 8 \\
\hline Elizabeth A. Orell & FSE & 8 & 4 & 4 & 8 \\
\hline Elizabeth A. Orell & FSE & 8 & 4 & 5 & 8 \\
\hline Elizabeth A. Orell & FSE & 8 & 4 & 6 & 8 \\
\hline Elizabeth A. Orell & FSE & 8 & 4 & 7 & 8 \\
\hline Elizabeth A. Orell & FSE & 8 & 4 & 8 & 8 \\
\hline Elizabeth A. Orell & FSE & 8 & 4 & 9 & 8 \\
\hline Elizabeth A. Orell & FSE & 8 & 4 & 10 & 8 \\
\hline Elizabeth A. Orell & FSE & 8 & 4 & 11 & 8 \\
\hline Elizabeth A. Orell & FSE & 8 & 4 & 12 & 8 \\
\hline Elizabeth A. Orell & FSE & 8 & 4 & 13 & 8 \\
\hline Elizabeth A. Orell & FSE & 8 & 4 & 14 & 8 \\
\hline Elizabeth A. Orell & FSE & 8 & 4 & 15 & 8 \\
\hline Elizabeth A. Orell & FSE & 8 & 4 & 16 & 8 \\
\hline Elizabeth A. Orell & FSE & 8 & 4 & 17 & 8 \\
\hline Elizabeth A. Orell & FSE & 8 & 4 & 18 & 8 \\
\hline Elizabeth A. Orell & FSE & 8 & 4 & 19 & 8 \\
\hline Elizabeth A. Orell & FSE & 8 & 4 & 20 & 8 \\
\hline Elizabeth A. Orell & FSE & 8 & 4 & 21 & 8 \\
\hline Elizabeth A. Orell & FSE & 8 & 4 & 22 & 8 \\
\hline Elizabeth A. Orell & FSE & 8 & 4 & 23 & 8 \\
\hline Elizabeth A. Orell & FSE & 8 & 4 & 24 & 8 \\
\hline Elizabeth A. Orell & FSE & 8 & 4 & 25 & 8 \\
\hline Elizabeth A. Orell & FSE & 8 & 4 & 26 & 8 \\
\hline Elizabeth A. Orell & FSE & 8 & 4 & 27 & 8 \\
\hline Elizabeth A. Orell & FSE & 8 & 4 & 28 & 8 \\
\hline Elizabeth A. Orell & FSE & 8 & 4 & 29 & 8 \\
\hline Elizabeth A. Orell & FSE & 8 & 4 & 30 & 8 \\
\hline Elizabeth A. Orell & FSE & 8 & 4 & 31 & 8 \\
\hline Elizabeth A. Orell & FSE & 8 & 4 & 32 & 8 \\
\hline Elizabeth A. Orell & FSE & 8 & 4 & 33 & 8 \\
\hline
\end{tabular}


STATE LAND APPLIED FOR UNDER SHALLOW NATURAL GAS LEASING PROGRAM

\begin{tabular}{|c|c|c|c|c|c|}
\hline Applicant & $\mathbf{M}$ & $\mathrm{T}$ & $\mathbf{R}$ & Section & Priority \\
\hline Elizabeth A. Orell & FSE & 8 & 4 & 34 & 8 \\
\hline Elizabeth A. Orell & FSE & 8 & 4 & 35 & 8 \\
\hline Elizabeth A. Orell & FSE & 8 & 4 & 36 & 8 \\
\hline Elizabeth A. Orell & FSE & 8 & 5 & 1 & 8 \\
\hline Elizabeth A. Orell & FSE & 8 & 5 & 2 & 8 \\
\hline Elizabeth A. Orell & FSE & 8 & 5 & 3 & 8 \\
\hline Elizabeth A. Orell & FSE & 8 & 5 & 4 & 8 \\
\hline Elizabeth A. Orell & FSE & 8 & 5 & 5 & 8 \\
\hline Elizabeth A. Orell & FSE & 8 & 5 & 6 & 8 \\
\hline Elizabeth A. Orell & FSE & 8 & 5 & 7 & 8 \\
\hline Elizabeth A. Orell & FSE & 8 & 5 & 8 & 8 \\
\hline Elizabeth A. Orell & FSE & 8 & 5 & 9 & 8 \\
\hline Elizabeth A. Orell & FSE & 8 & 5 & 10 & 8 \\
\hline Elizabeth A. Orell & FSE & 8 & 5 & 11 & 8 \\
\hline Elizabeth A. Orell & FSE & 8 & 5 & 12 & 8 \\
\hline Elizabeth A. Orell & FSE & 8 & 5 & 13 & 8 \\
\hline Elizabeth A. Orell & FSE & 8 & 5 & 14 & 8 \\
\hline Elizabeth A. Orell & FSE & 8 & 5 & 15 & 8 \\
\hline Elizabeth A. Orell & FSE & 8 & 5 & 16 & 8 \\
\hline Elizabeth A. Orell & FSE & 8 & 5 & 17 & 8 \\
\hline Elizabeth A. Orell & FSE & 8 & 5 & 18 & 8 \\
\hline Elizabeth A. Orell & FSE & 8 & 5 & 19 & 8 \\
\hline Elizabeth A. Orell & FSE & 8 & 5 & 20 & 8 \\
\hline Elizabeth A. Orell & FSE & 8 & 5 & 21 & 8 \\
\hline Elizabeth A. Orell & FSE & 8 & 5 & 28 & 8 \\
\hline Elizabeth A. Orell & FSE & 8 & 5 & 29 & 8 \\
\hline Elizabeth A. Orell & FSE & 8 & 5 & 30 & 8 \\
\hline Elizabeth A. Orell & FSE & 8 & 5 & 31 & 8 \\
\hline Elizabeth A. Orell & FSE & 8 & 5 & 32 & 8 \\
\hline Elizabeth A. Orell & FSE & 8 & 5 & 33 & 8 \\
\hline Jennifer L. Orell & FSE & 8 & 6 & 1 & 12 \\
\hline Jennifer L. Orell & FSE & 8 & 6 & 2 & 12 \\
\hline Jennifer L. Orell & FSE & 8 & 6 & 3 & 12 \\
\hline Jennifer L. Orell & FSE & 8 & 6 & 4 & 12 \\
\hline Jennifer L. Orell & FSE & 8 & 6 & 5 & 12 \\
\hline Jennifer L. Orell & FSE & 8 & 6 & 6 & 12 \\
\hline Jennifer L. Orell & FSE & 8 & 6 & 7 & 12 \\
\hline Jennifer L. Orell & FSE & 8 & 6 & 8 & 12 \\
\hline Jennifer L. Orell & FSE & 8 & 6 & 9 & 12 \\
\hline Jennifer L. Orell & FSE & 8 & 6 & 10 & 12 \\
\hline Jennifer L. Orell & FSE & 8 & 6 & 11 & 12 \\
\hline Jennifer L. Orell & FSE & 8 & 6 & 12 & 12 \\
\hline Jennifer L. Orell & FSE & 8 & 6 & 13 & 12 \\
\hline Jennifer L. Orell & FSE & 8 & 6 & 14 & 12 \\
\hline Jennifer L. Orell & FSE & 8 & 6 & 15 & 12 \\
\hline Jennifer L. Orell & FSE & 8 & 6 & 16 & 12 \\
\hline Jennifer L. Orell & FSE & 8 & 6 & 17 & 12 \\
\hline Jennifer L. Orell & FSE & 8 & 6 & 18 & 12 \\
\hline Jennifer L. Orell & FSE & 8 & 6 & 20 & 12 \\
\hline Jennifer L. Orell & FSE & 8 & 6 & 21 & 12 \\
\hline Jennifer L. Orell & FSE & 8 & 6 & 22 & 12 \\
\hline
\end{tabular}




\section{Applicant}

Jennifer L. Orell

Jennifer L. Orell

Jennifer L. Orell

Jennifer L. Orell

Jennifer L. Orell

Jennifer L. Orell

Jennifer L. Orell

Jennifer L. Orell

Jennifer L. Orell

Jennifer L. Orell

Jennifer L. Orell

Jennifer L. Orell

Jennifer L. Orell

Jennifer L. Orell

Jennifer L. Orell

Jennifer L. Orell

Jennifer L. Orell

Jennifer L. Orell

Jennifer L. Orell

Jennifer L. Orell

Jennifer L. Orell

Jennifer L. Orell

Jennifer L. Orell

Jennifer L. Orell

Jennifer L. Orell

Jennifer L. Orell

Jennifer L. Orell

Jennifer L. Orell

Jennifer L. Orell

Jennifer L. Orell

Jennifer L. Orell

Jennifer L. Orell

Jennifer L. Orell

Jennifer L. Orell

Jennifer L. Orell

Jennifer L. Orell

Jennifer L. Orell

Jennifer L. Orell

Jennifer L. Orell

Jennifer L. Orell

Jennifer L. Orell

Jennifer L. Orell

Jennifer L. Orell

Jennifer L. Orell

Jennifer L. Orell

Cory Lappi

Cory Lappi

Cory Lappi

Cory Lappi

Cory Lappi

Cory Lappi
M T R Section Priority

$\begin{array}{lllll}\text { FSE } & 8 & 6 & 23 & 12\end{array}$

$\begin{array}{lllll}\text { FSE } & 8 & 6 & 24 & 12\end{array}$

$\begin{array}{lllll}\text { FSE } & 8 & 6 & 25 & 12\end{array}$

$\begin{array}{lllll}\text { FSE } & 8 & 6 & 26 & 12\end{array}$

$\begin{array}{lllll}\text { FSE } & 8 & 6 & 27 & 12\end{array}$

$\begin{array}{lllll}\text { FSE } & 8 & 6 & 28 & 12\end{array}$

$\begin{array}{lllll}\text { FSE } & 8 & 6 & 34 & 12\end{array}$

$\begin{array}{lllll}\text { FSE } & 8 & 6 & 35 & 12\end{array}$

$\begin{array}{lllll}\text { FSE } & 8 & 6 & 36 & 12\end{array}$

$\begin{array}{lllll}\text { FSE } & 8 & 7 & 1 & 12\end{array}$

$\begin{array}{lllll}\text { FSE } & 8 & 7 & 2 & 12\end{array}$

$\begin{array}{lllll}\text { FSE } & 8 & 7 & 3 & 12\end{array}$

$\begin{array}{lllll}\text { FSE } & 8 & 7 & 4 & 12\end{array}$

$\begin{array}{lllll}\text { FSE } & 8 & 7 & 5 & 12\end{array}$

$\begin{array}{lllll}\text { FSE } & 8 & 7 & 6 & 12\end{array}$

$\begin{array}{lllll}\text { FSE } & 8 & 7 & 7 & 12\end{array}$

$\begin{array}{lllll}\text { FSE } & 8 & 7 & 8 & 12\end{array}$

$\begin{array}{lllll}\text { FSE } & 8 & 7 & 9 & 12\end{array}$

$\begin{array}{lllll}\text { FSE } & 8 & 7 & 10 & 12\end{array}$

$\begin{array}{lllll}\text { FSE } & 8 & 7 & 11 & 12\end{array}$

$\begin{array}{lllll}\text { FSE } & 8 & 7 & 12 & 12\end{array}$

$\begin{array}{lllll}\text { FSE } & 8 & 7 & 13 & 12\end{array}$

$\begin{array}{lllll}\text { FSE } & 8 & 7 & 14 & 12\end{array}$

$\begin{array}{lllll}\text { FSE } & 8 & 7 & 15 & 12\end{array}$

$\begin{array}{lllll}\text { FSE } & 8 & 7 & 16 & 12\end{array}$

$\begin{array}{lllll}\text { FSE } & 8 & 7 & 17 & 12\end{array}$

$\begin{array}{lllll}\text { FSE } & 8 & 7 & 18 & 12\end{array}$

$\begin{array}{lllll}\text { FSE } & 8 & 7 & 19 & 12\end{array}$

$\begin{array}{lllll}\text { FSE } & 8 & 7 & 20 & 12\end{array}$

$\begin{array}{lllll}\text { FSE } & 8 & 7 & 21 & 12\end{array}$

$\begin{array}{lllll}\text { FSE } & 8 & 7 & 22 & 12\end{array}$

$\begin{array}{lllll}\text { FSE } & 8 & 7 & 23 & 12\end{array}$

$\begin{array}{lllll}\text { FSE } & 8 & 7 & 24 & 12\end{array}$

$\begin{array}{lllll}\text { FSE } & 8 & 7 & 25 & 12\end{array}$

$\begin{array}{lllll}\text { FSE } & 8 & 7 & 26 & 12\end{array}$

$\begin{array}{lllll}\text { FSE } & 8 & 7 & 27 & 12\end{array}$

$\begin{array}{lllll}\text { FSE } & 8 & 7 & 28 & 12\end{array}$

$\begin{array}{lllll}\text { FSE } & 8 & 7 & 29 & 12\end{array}$

$\begin{array}{lllll}\text { FSE } & 8 & 7 & 30 & 12\end{array}$

$\begin{array}{lllll}\text { FSE } & 8 & 7 & 31 & 12\end{array}$

$\begin{array}{lllll}\text { FSE } & 8 & 7 & 32 & 12\end{array}$

$\begin{array}{lllll}\text { FSE } & 8 & 7 & 33 & 12\end{array}$

$\begin{array}{lllll}\text { FSE } & 8 & 7 & 34 & 12\end{array}$

$\begin{array}{lllll}\text { FSE } & 8 & 7 & 35 & 12\end{array}$

$\begin{array}{lllll}\text { FSE } & 8 & 7 & 36 & 12\end{array}$

$\begin{array}{lllll}\text { FSE } & 8 & 8 & 1 & 33\end{array}$

$\begin{array}{lllll}\text { FSE } & 8 & 8 & 2 & 33\end{array}$

$\begin{array}{lllll}\text { FSE } & 8 & 8 & 3 & 33\end{array}$

$\begin{array}{lllll}\text { FSE } & 8 & 8 & 4 & 33\end{array}$

$\begin{array}{lllll}\text { FSE } & 8 & 8 & 5 & 33\end{array}$

$\begin{array}{lllll}\text { FSE } & 8 & 8 & 6 & 33\end{array}$ 


\section{STATE LAND APPLIED FOR UNDER SHALLOW NATURAL GAS LEASING PROGRAM}

\begin{tabular}{|c|c|c|c|c|c|}
\hline Applicant & $\mathbf{M}$ & $\mathrm{T}$ & $\mathbf{R}$ & Section & Priority \\
\hline Cory Lappi & FSE & 8 & 8 & 7 & 33 \\
\hline Cory Lappi & FSE & 8 & 8 & 8 & 33 \\
\hline Cory Lappi & FSE & 8 & 8 & 9 & 33 \\
\hline Cory Lappi & FSE & 8 & 8 & 10 & 33 \\
\hline Cory Lappi & FSE & 8 & 8 & 11 & 33 \\
\hline Cory Lappi & FSE & 8 & 8 & 12 & 33 \\
\hline Cory Lappi & FSE & 8 & 8 & 13 & 33 \\
\hline Cory Lappi & FSE & 8 & 8 & 14 & 33 \\
\hline Cory Lappi & FSE & 8 & 8 & 15 & 33 \\
\hline Cory Lappi & FSE & 8 & 8 & 16 & 33 \\
\hline Cory Lappi & FSE & 8 & 8 & 17 & 33 \\
\hline Cory Lappi & FSE & 8 & 8 & 18 & 33 \\
\hline Jennifer L. Orell & FSE & 8 & 8 & 19 & 12 \\
\hline Jennifer L. Orell & FSE & 8 & 8 & 20 & 12 \\
\hline Cory Lappi & FSE & 8 & 8 & 21 & 33 \\
\hline Cory Lappi & FSE & 8 & 8 & 22 & 33 \\
\hline Cory Lappi & FSE & 8 & 8 & 23 & 33 \\
\hline Cory Lappi & FSE & 8 & 8 & 24 & 33 \\
\hline Cory Lappi & FSE & 8 & 8 & 25 & 33 \\
\hline Cory Lappi & FSE & 8 & 8 & 26 & 33 \\
\hline Cory Lappi & FSE & 8 & 8 & 27 & 33 \\
\hline Cory Lappi & FSE & 8 & 8 & 28 & 33 \\
\hline Jennifer L. Orell & FSE & 8 & 8 & 29 & 12 \\
\hline Jennifer L. Orell & FSE & 8 & 8 & 30 & 12 \\
\hline Jennifer L. Orell & FSE & 8 & 8 & 31 & 12 \\
\hline Jennifer L. Orell & FSE & 8 & 8 & 32 & 12 \\
\hline Cory Lappi & FSE & 8 & 8 & 33 & 33 \\
\hline Cory Lappi & FSE & 8 & 8 & 34 & 33 \\
\hline Cory Lappi & FSE & 8 & 8 & 35 & 33 \\
\hline Cory Lappi & FSE & 8 & 8 & 36 & 33 \\
\hline Cory Lappi & FSE & 8 & 9 & 17 & 33 \\
\hline Cory Lappi & FSE & 8 & 9 & 18 & 33 \\
\hline Cory Lappi & FSE & 8 & 9 & 19 & 33 \\
\hline Cory Lappi & FSE & 8 & 9 & 20 & 33 \\
\hline Cory Lappi & FSE & 8 & 9 & 21 & 33 \\
\hline Cory Lappi & FSE & 8 & 9 & 22 & 33 \\
\hline Cory Lappi & FSE & 8 & 9 & 27 & 33 \\
\hline Cory Lappi & FSE & 8 & 9 & 28 & 33 \\
\hline Cory Lappi & FSE & 8 & 9 & 29 & 33 \\
\hline Cory Lappi & FSE & 8 & 9 & 30 & 33 \\
\hline Cory Lappi & FSE & 8 & 9 & 31 & 33 \\
\hline Cory Lappi & FSE & 8 & 9 & 32 & 33 \\
\hline Cory Lappi & FSE & 8 & 9 & 33 & 33 \\
\hline Cory Lappi & FSE & 8 & 9 & 34 & 33 \\
\hline Elizabeth A. Orell & FSE & 9 & 3 & 1 & 8 \\
\hline Elizabeth A. Orell & FSE & 9 & 3 & 2 & 8 \\
\hline Elizabeth A. Orell & FSE & 9 & 3 & 3 & 8 \\
\hline Elizabeth A. Orell & FSE & 9 & 3 & 10 & 8 \\
\hline Elizabeth A. Orell & FSE & 9 & 3 & 11 & 8 \\
\hline Elizabeth A. Orell & FSE & 9 & 3 & 12 & 8 \\
\hline Elizabeth A. Orell & FSE & 9 & 3 & 13 & 8 \\
\hline
\end{tabular}




\section{STATE LAND APPLIED FOR UNDER SHALLOW NATURAL GAS LEASING PROGRAM}

\section{Applicant}

Troy Lappi

Troy Lappi

Troy Lappi

Troy Lappi

Troy Lappi

Troy Lappi

Troy Lappi

Troy Lappi

Troy Lappi

Troy Lappi

Troy Lappi

Troy Lappi

Troy Lappi

Troy Lappi

Troy Lappi

Troy Lappi

Troy Lappi

Troy Lappi

Troy Lappi

Troy Lappi

Troy Lappi

Troy Lappi

Troy Lappi

Troy Lappi

Troy Lappi

Troy Lappi

Troy Lappi

Troy Lappi

Troy Lappi

Troy Lappi

Troy Lappi

Troy Lappi

Troy Lappi

Troy Lappi

Troy Lappi

Troy Lappi

Troy Lappi

Troy Lappi

Troy Lappi

Troy Lappi

Troy Lappi

Troy Lappi

Karen L. Fitzpatrick

Karen L. Fitzpatrick

Karen L. Fitzpatrick

Karen L. Fitzpatrick

Karen L. Fitzpatrick

Karen L. Fitzpatrick

Karen L. Fitzpatrick

Karen L. Fitzpatrick

Karen L. Fitzpatrick
$\begin{array}{lllll}M & \text { T } & \text { R } & \text { Section } & \text { Priority }\end{array}$

$\begin{array}{lllll}\text { FSE } & 9 & 5 & 31 & 17\end{array}$

$\begin{array}{lllll}\text { FSE } & 9 & 5 & 32 & 17\end{array}$

$\begin{array}{lllll}\text { FSE } & 9 & 6 & 1 & 17\end{array}$

$\begin{array}{lllll}\text { FSE } & 9 & 7 & 1 & 17\end{array}$

$\begin{array}{lllll}\text { FSE } & 9 & 7 & 2 & 17\end{array}$

$\begin{array}{lllll}\text { FSE } & 9 & 7 & 3 & 17\end{array}$

$\begin{array}{lllll}\text { FSE } & 9 & 7 & 4 & 17\end{array}$

$\begin{array}{lllll}\text { FSE } & 9 & 7 & 5 & 17\end{array}$

$\begin{array}{lllll}\text { FSE } & 9 & 7 & 6 & 17\end{array}$

$\begin{array}{lllll}\text { FSE } & 9 & 7 & 7 & 17\end{array}$

$\begin{array}{lllll}\text { FSE } & 9 & 7 & 8 & 17\end{array}$

$\begin{array}{lllll}\text { FSE } & 9 & 7 & 9 & 17\end{array}$

$\begin{array}{lllll}\text { FSE } & 9 & 7 & 10 & 17\end{array}$

$\begin{array}{lllll}\text { FSE } & 9 & 7 & 11 & 17\end{array}$

$\begin{array}{lllll}\text { FSE } & 9 & 7 & 12 & 17\end{array}$

$\begin{array}{lllll}\text { FSE } & 9 & 7 & 13 & 17\end{array}$

$\begin{array}{lllll}\text { FSE } & 9 & 7 & 14 & 17\end{array}$

$\begin{array}{lllll}\text { FSE } & 9 & 7 & 15 & 17\end{array}$

$\begin{array}{lllll}\text { FSE } & 9 & 7 & 16 & 17\end{array}$

$\begin{array}{lllll}\text { FSE } & 9 & 7 & 22 & 17\end{array}$

$\begin{array}{lllll}\text { FSE } & 9 & 7 & 23 & 17\end{array}$

$\begin{array}{lllll}\text { FSE } & 9 & 7 & 24 & 17\end{array}$

$\begin{array}{lllll}\text { FSE } & 9 & 7 & 25 & 17\end{array}$

$\begin{array}{lllll}\text { FSE } & 9 & 7 & 26 & 17\end{array}$

$\begin{array}{lllll}\text { FSE } & 9 & 8 & 1 & 17\end{array}$

$\begin{array}{lllll}\text { FSE } & 9 & 8 & 2 & 17\end{array}$

$\begin{array}{lllll}\text { FSE } & 9 & 8 & 3 & 17\end{array}$

$\begin{array}{lllll}\text { FSE } & 9 & 8 & 4 & 17\end{array}$

$\begin{array}{lllll}\text { FSE } & 9 & 8 & 5 & 17\end{array}$

$\begin{array}{lllll}\text { FSE } & 9 & 8 & 6 & 17\end{array}$

$\begin{array}{lllll}\text { FSE } & 9 & 8 & 7 & 17\end{array}$

$\begin{array}{lllll}\text { FSE } & 9 & 8 & 8 & 17\end{array}$

$\begin{array}{lllll}\text { FSE } & 9 & 8 & 9 & 17\end{array}$

$\begin{array}{lllll}\text { FSE } & 9 & 8 & 10 & 17\end{array}$

$\begin{array}{lllll}\text { FSE } & 9 & 8 & 11 & 17\end{array}$

$\begin{array}{lllll}\text { FSE } & 9 & 8 & 12 & 17\end{array}$

$\begin{array}{lllll}\text { FSE } & 9 & 8 & 13 & 17\end{array}$

$\begin{array}{lllll}\text { FSE } & 9 & 8 & 14 & 17\end{array}$

$\begin{array}{lllll}\text { FSE } & 9 & 8 & 15 & 17\end{array}$

$\begin{array}{lllll}\text { FSE } & 9 & 8 & 16 & 17\end{array}$

$\begin{array}{lllll}\text { FSE } & 9 & 8 & 17 & 17\end{array}$

$\begin{array}{lllll}\text { FSE } & 9 & 8 & 18 & 17\end{array}$

$\begin{array}{lllll}\text { FSE } & 9 & 8 & 19 & 35\end{array}$

$\begin{array}{lllll}\text { FSE } & 9 & 8 & 20 & 35\end{array}$

$\begin{array}{lllll}\text { FSE } & 9 & 8 & 21 & 35\end{array}$

$\begin{array}{lllll}\text { FSE } & 9 & 8 & 22 & 35\end{array}$

$\begin{array}{lllll}\text { FSE } & 9 & 8 & 23 & 35\end{array}$

$\begin{array}{lllll}\text { FSE } & 9 & 8 & 24 & 35\end{array}$

$\begin{array}{lllll}\text { FSE } & 9 & 8 & 25 & 35\end{array}$

$\begin{array}{lllll}\text { FSE } & 9 & 8 & 26 & 35\end{array}$

$\begin{array}{lllll}\text { FSE } & 9 & 8 & 27 & 35\end{array}$ 


\begin{tabular}{|c|c|c|c|c|c|}
\hline Applicant & $\mathbf{M}$ & $\mathrm{T}$ & $\mathbf{R}$ & Section & Priority \\
\hline Karen L. Fitzpatrick & FSE & 9 & 8 & 28 & 35 \\
\hline Karen L. Fitzpatrick & FSE & 9 & 8 & 29 & 35 \\
\hline Karen L. Fitzpatrick & FSE & 9 & 8 & 30 & 35 \\
\hline Karen L. Fitzpatrick & FSE & 9 & 8 & 31 & 35 \\
\hline Karen L. Fitzpatrick & FSE & 9 & 8 & 32 & 35 \\
\hline Karen L. Fitzpatrick & FSE & 9 & 8 & 33 & 35 \\
\hline Karen L. Fitzpatrick & FSE & 9 & 8 & 34 & 35 \\
\hline Karen L. Fitzpatrick & FSE & 9 & 8 & 35 & 35 \\
\hline Karen L. Fitzpatrick & FSE & 9 & 8 & 36 & 35 \\
\hline Karen L. Fitzpatrick & FSE & 9 & 9 & 1 & 35 \\
\hline Karen L. Fitzpatrick & FSE & 9 & 9 & 2 & 35 \\
\hline Karen L. Fitzpatrick & FSE & 9 & 9 & 3 & 35 \\
\hline Karen L. Fitzpatrick & FSE & 9 & 9 & 4 & 35 \\
\hline Karen L. Fitzpatrick & FSE & 9 & 9 & 5 & 35 \\
\hline Karen L. Fitzpatrick & FSE & 9 & 9 & 6 & 35 \\
\hline Karen L. Fitzpatrick & FSE & 9 & 9 & 7 & 35 \\
\hline Karen L. Fitzpatrick & FSE & 9 & 9 & 8 & 35 \\
\hline Karen L. Fitzpatrick & FSE & 9 & 9 & 9 & 35 \\
\hline Karen L. Fitzpatrick & FSE & 9 & 9 & 10 & 35 \\
\hline Karen L. Fitzpatrick & FSE & 9 & 9 & 11 & 35 \\
\hline Karen L. Fitzpatrick & FSE & 9 & 9 & 12 & 35 \\
\hline Karen L. Fitzpatrick & FSE & 9 & 9 & 13 & 35 \\
\hline Karen L. Fitzpatrick & FSE & 9 & 9 & 14 & 35 \\
\hline Karen L. Fitzpatrick & FSE & 9 & 9 & 15 & 35 \\
\hline Karen L. Fitzpatrick & FSE & 9 & 9 & 16 & 35 \\
\hline Karen L. Fitzpatrick & FSE & 9 & 9 & 17 & 35 \\
\hline Karen L. Fitzpatrick & FSE & 9 & 9 & 18 & 35 \\
\hline Karen L. Fitzpatrick & FSE & 9 & 9 & 19 & 35 \\
\hline Karen L. Fitzpatrick & FSE & 9 & 9 & 20 & 35 \\
\hline Karen L. Fitzpatrick & FSE & 9 & 9 & 21 & 35 \\
\hline Karen L. Fitzpatrick & FSE & 9 & 9 & 22 & 35 \\
\hline Karen L. Fitzpatrick & FSE & 9 & 9 & 23 & 35 \\
\hline Karen L. Fitzpatrick & FSE & 9 & 9 & 24 & 35 \\
\hline Karen L. Fitzpatrick & FSE & 9 & 9 & 25 & 35 \\
\hline Karen L. Fitzpatrick & FSE & 9 & 9 & 26 & 35 \\
\hline Karen L. Fitzpatrick & FSE & 9 & 9 & 27 & 35 \\
\hline Karen L. Fitzpatrick & FSE & 9 & 9 & 28 & 35 \\
\hline Karen L. Fitzpatrick & FSE & 9 & 9 & 29 & 35 \\
\hline Karen L. Fitzpatrick & FSE & 9 & 9 & 30 & 35 \\
\hline Karen L. Fitzpatrick & FSE & 9 & 9 & 31 & 35 \\
\hline Karen L. Fitzpatrick & FSE & 9 & 9 & 32 & 35 \\
\hline Karen L. Fitzpatrick & FSE & 9 & 9 & 33 & 35 \\
\hline Karen L. Fitzpatrick & FSE & 9 & 9 & 34 & 35 \\
\hline Karen L. Fitzpatrick & FSE & 9 & 9 & 35 & 35 \\
\hline Karen L. Fitzpatrick & FSE & 9 & 9 & 36 & 35 \\
\hline Karen L. Fitzpatrick & FSE & 9 & 10 & 19 & 35 \\
\hline Karen L. Fitzpatrick & FSE & 9 & 10 & 20 & 35 \\
\hline Karen L. Fitzpatrick & FSE & 9 & 10 & 21 & 35 \\
\hline Karen L. Fitzpatrick & FSE & 9 & 10 & 28 & 35 \\
\hline Karen L. Fitzpatrick & FSE & 9 & 10 & 29 & 35 \\
\hline Karen L. Fitzpatrick & FSE & 9 & 10 & 30 & 35 \\
\hline
\end{tabular}




\section{Applicant}

Karen L. Fitzpatrick

Karen L. Fitzpatrick

Karen L. Fitzpatrick

Karen L. Fitzpatrick

Karen L. Fitzpatrick

Karen L. Fitzpatrick

Karen L. Fitzpatrick

Karen L. Fitzpatrick

Karen L. Fitzpatrick

Karen L. Fitzpatrick

Karen L. Fitzpatrick

Karen L. Fitzpatrick

Troy Lappi

Troy Lappi

Troy Lappi

Linda O. Lappi

Linda O. Lappi

Linda O. Lappi

Linda O. Lappi

Linda O. Lappi

Linda O. Lappi

Linda O. Lappi

Linda O. Lappi

Linda O. Lappi

Linda O. Lappi

Linda O. Lappi

Linda O. Lappi

Linda O. Lappi

Linda O. Lappi

Linda O. Lappi

Linda O. Lappi

Linda O. Lappi

Linda O. Lappi

Linda O. Lappi

Linda O. Lappi

Linda O. Lappi

Linda O. Lappi

Linda O. Lappi

Linda O. Lappi

Linda O. Lappi

Linda O. Lappi

Linda O. Lappi

Linda O. Lappi

Linda O. Lappi

Linda O. Lappi

Linda O. Lappi

Linda O. Lappi

Linda O. Lappi

Linda O. Lappi

Linda O. Lappi

Linda O. Lappi

\begin{tabular}{|c|c|c|c|c|}
\hline$M$ & $\mathrm{~T}$ & $\mathbf{R}$ & Section & Priority \\
\hline FSE & 9 & 10 & 31 & 35 \\
\hline FSE & 9 & 10 & 32 & 35 \\
\hline FSE & 9 & 10 & 33 & 35 \\
\hline FSE & 10 & 4 & 1 & 35 \\
\hline FSE & 10 & 4 & 2 & 35 \\
\hline FSE & 10 & 4 & 3 & 35 \\
\hline FSE & 10 & 4 & 10 & 35 \\
\hline FSE & 10 & 4 & 11 & 35 \\
\hline FSE & 10 & 4 & 12 & 35 \\
\hline FSE & 10 & 4 & 13 & 35 \\
\hline FSE & 10 & 4 & 14 & 35 \\
\hline FSE & 10 & 4 & 15 & 35 \\
\hline FSE & 10 & 5 & 6 & 17 \\
\hline FSE & 10 & 5 & 7 & 17 \\
\hline FSE & 10 & 5 & 18 & 17 \\
\hline FSE & 10 & 8 & 1 & 16 \\
\hline FSE & 10 & 8 & 2 & 16 \\
\hline FSE & 10 & 8 & 3 & 16 \\
\hline FSE & 10 & 8 & 4 & 16 \\
\hline FSE & 10 & 8 & 5 & 16 \\
\hline FSE & 10 & 8 & 9 & 16 \\
\hline FSE & 10 & 8 & 10 & 16 \\
\hline FSE & 10 & 8 & 11 & 16 \\
\hline FSE & 10 & 8 & 12 & 16 \\
\hline FSE & 10 & 8 & 13 & 16 \\
\hline FSE & 10 & 8 & 14 & 16 \\
\hline FSE & 10 & 8 & 24 & 16 \\
\hline FSE & 10 & 9 & 1 & 16 \\
\hline FSE & 10 & 9 & 2 & 16 \\
\hline FSE & 10 & 9 & 3 & 16 \\
\hline FSE & 10 & 9 & 4 & 16 \\
\hline FSE & 10 & 9 & 5 & 16 \\
\hline FSE & 10 & 9 & 6 & 16 \\
\hline FSE & 10 & 9 & 7 & 16 \\
\hline FSE & 10 & 9 & 8 & 16 \\
\hline FSE & 10 & 9 & 9 & 16 \\
\hline FSE & 10 & 9 & 10 & 16 \\
\hline FSE & 10 & 9 & 11 & 16 \\
\hline FSE & 10 & 9 & 12 & 16 \\
\hline FSE & 10 & 9 & 13 & 16 \\
\hline FSE & 10 & 9 & 14 & 16 \\
\hline FSE & 10 & 9 & 15 & 16 \\
\hline FSE & 10 & 9 & 16 & 16 \\
\hline FSE & 10 & 9 & 17 & 16 \\
\hline FSE & 10 & 9 & 18 & 16 \\
\hline FSE & 10 & 9 & 19 & 16 \\
\hline FSE & 10 & 9 & 20 & 16 \\
\hline FSE & 10 & 9 & 21 & 16 \\
\hline FSE & 10 & 9 & 22 & 16 \\
\hline FSE & 10 & 9 & 23 & 16 \\
\hline FSE & 10 & 9 & 24 & 16 \\
\hline
\end{tabular}

Page 11 of 45 
STATE LAND APPLIED FOR UNDER SHALLOW NATURAL GAS LEASING PROGRAM

\begin{tabular}{|c|c|c|c|c|c|}
\hline Applicant & M & $\mathrm{T}$ & $\mathbf{R}$ & Section & Priority \\
\hline Linda O. Lappi & FSE & 10 & 9 & 25 & 16 \\
\hline Linda O. Lappi & FSE & 10 & 9 & 26 & 16 \\
\hline Linda O. Lappi & FSE & 10 & 9 & 27 & 16 \\
\hline Linda O. Lappi & FSE & 10 & 9 & 28 & 16 \\
\hline Linda O. Lappi & FSE & 10 & 9 & 29 & 16 \\
\hline Linda O. Lappi & FSE & 10 & 9 & 30 & 16 \\
\hline Linda O. Lappi & FSE & 10 & 9 & 33 & 16 \\
\hline Linda O. Lappi & FSE & 10 & 9 & 34 & 16 \\
\hline Linda O. Lappi & FSE & 10 & 9 & 35 & 16 \\
\hline Linda O. Lappi & FSE & 10 & 9 & 36 & 16 \\
\hline Raymond R. Latchem & FSE & 10 & 10 & 1 & 21 \\
\hline Raymond R. Latchem & FSE & 10 & 10 & 2 & 21 \\
\hline Linda O. Lappi & FSE & 10 & 10 & 4 & 16 \\
\hline Linda O. Lappi & FSE & 10 & 10 & 5 & 16 \\
\hline Linda O. Lappi & FSE & 10 & 10 & 6 & 16 \\
\hline Linda O. Lappi & FSE & 10 & 10 & 7 & 16 \\
\hline Linda O. Lappi & FSE & 10 & 10 & 8 & 16 \\
\hline Linda O. Lappi & FSE & 10 & 10 & 9 & 16 \\
\hline Linda O. Lappi & FSE & 10 & 10 & 10 & 16 \\
\hline Raymond R. Latchem & FSE & 10 & 10 & 11 & 21 \\
\hline Raymond R. Latchem & FSE & 10 & 10 & 12 & 21 \\
\hline Raymond R. Latchem & FSE & 10 & 10 & 13 & 21 \\
\hline Raymond R. Latchem & FSE & 10 & 10 & 14 & 21 \\
\hline Linda O. Lappi & FSE & 10 & 10 & 15 & 16 \\
\hline Linda O. Lappi & FSE & 10 & 10 & 16 & 16 \\
\hline Linda O. Lappi & FSE & 10 & 10 & 17 & 16 \\
\hline Linda O. Lappi & FSE & 10 & 10 & 18 & 16 \\
\hline Linda O. Lappi & FSE & 10 & 10 & 19 & 16 \\
\hline Linda O. Lappi & FSE & 10 & 10 & 20 & 16 \\
\hline Linda O. Lappi & FSE & 10 & 10 & 21 & 16 \\
\hline Linda O. Lappi & FSE & 10 & 10 & 22 & 16 \\
\hline Linda O. Lappi & FSE & 10 & 10 & 27 & 16 \\
\hline Linda O. Lappi & FSE & 10 & 10 & 28 & 16 \\
\hline Linda O. Lappi & FSE & 10 & 10 & 29 & 16 \\
\hline Linda O. Lappi & FSE & 10 & 10 & 30 & 16 \\
\hline Linda O. Lappi & FSE & 10 & 10 & 31 & 16 \\
\hline Linda O. Lappi & FSE & 10 & 10 & 32 & 16 \\
\hline Linda O. Lappi & FSE & 10 & 10 & 33 & 16 \\
\hline Raymond R. Latchem & FSE & 10 & 11 & 6 & 21 \\
\hline Raymond R. Latchem & FSE & 10 & 11 & 7 & 21 \\
\hline Raymond R. Latchem & FSE & 10 & 11 & 18 & 21 \\
\hline John C. Teich & FSW & 4 & 7 & 25 & 7 \\
\hline John C. Teich & FSW & 4 & 7 & 26 & 7 \\
\hline John C. Teich & FSW & 4 & 7 & 27 & 7 \\
\hline John C. Teich & FSW & 4 & 7 & 28 & 7 \\
\hline John C. Teich & FSW & 4 & 7 & 29 & 7 \\
\hline Shannon G. Latchem & FSW & 4 & 7 & 30 & 30 \\
\hline John C. Teich & FSW & 4 & 7 & 31 & 7 \\
\hline Shannon G. Latchem & FSW & 4 & 7 & 31 & 30 \\
\hline John C. Teich & FSW & 4 & 7 & 32 & 7 \\
\hline
\end{tabular}




\section{STATE LAND APPLIED FOR UNDER SHALLOW NATURAL GAS LEASING PROGRAM}

\section{Applicant}

John C. Teich

John C. Teich

John C. Teich

John C. Teich

Shannon G. Latchem

Shannon G. Latchem

Shannon G. Latchem

Shannon G. Latchem

Shannon G. Latchem

John C. Teich

John C. Teich

John C. Teich

John C. Teich

John C. Teich

John C. Teich

John C. Teich

John C. Teich

John C. Teich

John C. Teich

John C. Teich

John C. Teich

John C. Teich

John C. Teich

John C. Teich

Dennis A. Murray

Dennis A. Murray

Dennis A. Murray

Dennis A. Murray

Dennis A. Murray

Dennis A. Murray

Dennis A. Murray

Dennis A. Murray

Dennis A. Murray

Dennis A. Murray

Dennis A. Murray

Dennis A. Murray

Dennis A. Murray

Dennis A. Murray

Dennis A. Murray

Shannon G. Latchem

Shannon G. Latchem

John C. Teich

John C. Teich

John C. Teich

John C. Teich

John C. Teich

John C. Teich

John C. Teich

John C. Teich

John C. Teich

John C. Teich

\section{$\begin{array}{lllll}\text { M } & \text { T } & \text { R } & \text { Section } & \text { Priority }\end{array}$}

$\begin{array}{llll}\text { FSW } & 4 & 7 & \\ \text { FSW } & 4 & 7 & \\ \text { FSW } & 4 & 7\end{array}$

$\begin{array}{lllll}\text { FSW } & 4 & 7 & 36 & 7\end{array}$

$\begin{array}{lllll}\text { FSW } & 4 & 8 & 24 & 30\end{array}$

$\begin{array}{lllll}\text { FSW } & 4 & 8 & 25 & 30\end{array}$

$\begin{array}{lllll}\text { FSW } & 4 & 8 & 26 & 30\end{array}$

$\begin{array}{lllll}\text { FSW } & 4 & 8 & 35 & 30\end{array}$

$\begin{array}{lllll}\text { FSW } & 4 & 8 & 36 & 30\end{array}$

$\begin{array}{lllll}\text { FSW } & 5 & 7 & 1 & 7\end{array}$

$\begin{array}{lllll}\text { FSW } & 5 & 7 & 2 & 7\end{array}$

$\begin{array}{lllll}\text { FSW } & 5 & 7 & 3 & 7\end{array}$

$\begin{array}{lllll}\text { FSW } & 5 & 7 & 4 & 7\end{array}$

$\begin{array}{lllll}\text { FSW } & 5 & 7 & 5 & 7\end{array}$

$\begin{array}{lllll}\text { FSW } & 5 & 7 & 8 & 7\end{array}$

$\begin{array}{lllll}\text { FSW } & 5 & 7 & 9 & 7\end{array}$

$\begin{array}{lllll}\text { FSW } & 5 & 7 & 10 & 7\end{array}$

$\begin{array}{lllll}\text { FSW } & 5 & 7 & 11 & 7\end{array}$

$\begin{array}{lllll}\text { FSW } & 5 & 7 & 12 & 7\end{array}$

$\begin{array}{lllll}\text { FSW } & 5 & 7 & 13 & 7\end{array}$

$\begin{array}{lllll}\text { FSW } & 5 & 7 & 14 & 7\end{array}$

$\begin{array}{lllll}\text { FSW } & 5 & 7 & 15 & 7\end{array}$

$\begin{array}{lllll}\text { FSW } & 5 & 7 & 16 & 7\end{array}$

$\begin{array}{lllll}\text { FSW } & 5 & 7 & 17 & 7\end{array}$

$\begin{array}{lllll}\text { FSW } & 5 & 7 & 20 & 15\end{array}$

$\begin{array}{lllll}\text { FSW } & 5 & 7 & 21 & 15\end{array}$

$\begin{array}{lllll}\text { FSW } & 5 & 7 & 22 & 15\end{array}$

$\begin{array}{lllll}\text { FSW } & 5 & 7 & 23 & 15\end{array}$

$\begin{array}{lllll}\text { FSW } & 5 & 7 & 24 & 15\end{array}$

$\begin{array}{lllll}\text { FSW } & 5 & 7 & 25 & 15\end{array}$

$\begin{array}{lllll}\text { FSW } & 5 & 7 & 26 & 15\end{array}$

$\begin{array}{lllll}\text { FSW } & 5 & 7 & 27 & 15\end{array}$

$\begin{array}{lllll}\text { FSW } & 5 & 7 & 28 & 15\end{array}$

$\begin{array}{lllll}\text { FSW } & 5 & 7 & 29 & 15\end{array}$

$\begin{array}{lllll}\text { FSW } & 5 & 7 & 32 & 15\end{array}$

$\begin{array}{lllll}\text { FSW } & 5 & 7 & 33 & 15\end{array}$

$\begin{array}{lllll}\text { FSW } & 5 & 7 & 34 & 15\end{array}$

$\begin{array}{lllll}\text { FSW } & 5 & 7 & 35 & 15\end{array}$

$\begin{array}{lllll}\text { FSW } & 5 & 7 & 36 & 15\end{array}$

$\begin{array}{lllll}\text { FSW } & 5 & 8 & 1 & 30\end{array}$

$\begin{array}{lllll}\text { FSW } & 5 & 8 & 2 & 30\end{array}$

$\begin{array}{lllll}\text { FSW } & 5 & 8 & 3 & 7\end{array}$

$\begin{array}{lllll}\text { FSW } & 5 & 8 & 4 & 7\end{array}$

$\begin{array}{lllll}\text { FSW } & 5 & 8 & 5 & 7\end{array}$

$\begin{array}{lllll}\text { FSW } & 5 & 8 & 6 & 7\end{array}$

$\begin{array}{lllll}\text { FSW } & 5 & 8 & 7 & 7\end{array}$

$\begin{array}{lllll}\text { FSW } & 5 & 8 & 8 & 7\end{array}$

$\begin{array}{lllll}\text { FSW } & 5 & 8 & 9 & 7\end{array}$

$\begin{array}{lllll}\text { FSW } & 5 & 8 & 10 & 7\end{array}$

$\begin{array}{lllll}\text { FSW } & 5 & 8 & 15 & 7\end{array}$

$\begin{array}{lllll}\text { FSW } & 5 & 8 & 16 & 7\end{array}$ 


\begin{tabular}{|c|c|c|c|c|c|}
\hline Applicant & $\mathbf{M}$ & $\mathbf{T}$ & $\mathbf{R}$ & Section & Priority \\
\hline John C. Teich & FSW & 5 & 8 & 17 & 7 \\
\hline John C. Teich & FSW & 5 & 8 & 18 & 7 \\
\hline John C. Teich & FSW & 5 & 8 & 19 & 7 \\
\hline John C. Teich & FSW & 5 & 8 & 20 & 7 \\
\hline John C. Teich & FSW & 5 & 8 & 21 & 7 \\
\hline John C. Teich & FSW & 5 & 8 & 22 & 7 \\
\hline John C. Teich & FSW & 5 & 8 & 27 & 7 \\
\hline John C. Teich & FSW & 5 & 8 & 28 & 7 \\
\hline John C. Teich & FSW & 5 & 8 & 29 & 7 \\
\hline John C. Teich & FSW & 5 & 8 & 30 & 7 \\
\hline John C. Teich & FSW & 5 & 8 & 31 & 7 \\
\hline John C. Teich & FSW & 5 & 8 & 32 & 7 \\
\hline John C. Teich & FSW & 5 & 8 & 34 & 7 \\
\hline Dennis A. Murray & FSW & 6 & 7 & 1 & 15 \\
\hline Dennis A. Murray & FSW & 6 & 7 & 2 & 15 \\
\hline Dennis A. Murray & FSW & 6 & 7 & 3 & 15 \\
\hline Dennis A. Murray & FSW & 6 & 7 & 4 & 15 \\
\hline Dennis A. Murray & FSW & 6 & 7 & 5 & 15 \\
\hline Dennis A. Murray & FSW & 6 & 7 & 8 & 15 \\
\hline Dennis A. Murray & FSW & 6 & 7 & 9 & 15 \\
\hline Dennis A. Murray & FSW & 6 & 7 & 10 & 15 \\
\hline Dennis A. Murray & FSW & 6 & 7 & 11 & 15 \\
\hline Dennis A. Murray & FSW & 6 & 7 & 12 & 15 \\
\hline Dennis A. Murray & FSW & 6 & 7 & 13 & 15 \\
\hline Dennis A. Murray & FSW & 6 & 7 & 14 & 15 \\
\hline Dennis A. Murray & FSW & 6 & 7 & 15 & 15 \\
\hline Dennis A. Murray & FSW & 6 & 7 & 16 & 15 \\
\hline Dennis A. Murray & FSW & 6 & 7 & 17 & 15 \\
\hline Dennis A. Murray & FSW & 6 & 7 & 20 & 15 \\
\hline Dennis A. Murray & FSW & 6 & 7 & 21 & 15 \\
\hline Dennis A. Murray & FSW & 6 & 7 & 22 & 15 \\
\hline Dennis A. Murray & FSW & 6 & 7 & 23 & 15 \\
\hline Dennis A. Murray & FSW & 6 & 7 & 24 & 15 \\
\hline Dennis A. Murray & FSW & 6 & 7 & 25 & 15 \\
\hline Dennis A. Murray & FSW & 6 & 7 & 26 & 15 \\
\hline Dennis A. Murray & FSW & 6 & 7 & 27 & 15 \\
\hline Dennis A. Murray & FSW & 6 & 7 & 28 & 15 \\
\hline Dennis A. Murray & FSW & 6 & 7 & 29 & 15 \\
\hline Dennis A. Murray & FSW & 6 & 7 & 32 & 15 \\
\hline Dennis A. Murray & FSW & 6 & 7 & 33 & 15 \\
\hline Dennis A. Murray & FSW & 6 & 7 & 34 & 15 \\
\hline Dennis A. Murray & FSW & 6 & 7 & 35 & 15 \\
\hline Dennis A. Murray & FSW & 6 & 7 & 36 & 15 \\
\hline Dennis A. Murray & FSW & 6 & 8 & 4 & 15 \\
\hline Dennis A. Murray & FSW & 6 & 8 & 5 & 15 \\
\hline Dennis A. Murray & FSW & 6 & 8 & 6 & 15 \\
\hline Dennis A. Murray & FSW & 6 & 8 & 7 & 15 \\
\hline Dennis A. Murray & FSW & 6 & 8 & 8 & 15 \\
\hline Dennis A. Murray & FSW & 6 & 8 & 9 & 15 \\
\hline Dennis A. Murray & FSW & 6 & 8 & 16 & 15 \\
\hline Dennis A. Murray & FSW & 6 & 8 & 17 & 15 \\
\hline
\end{tabular}


STATE LAND APPLIED FOR UNDER SHALLOW NATURAL GAS LEASING PROGRAM

\section{Applicant}

Dennis A. Murray

Dennis A. Murray

Dennis A. Murray

Dennis A. Murray

Shannon G. Latchem

Shannon G. Latchem

Shannon G. Latchem

Dennis A. Murray

Shannon G. Latchem

Dennis A. Murray

Shannon G. Latchem

Dennis A. Murray

Dennis A. Murray

Dennis A. Murray

Dennis A. Murray

Shannon G. Latchem

Shannon G. Latchem

Shannon G. Latchem

Shannon G. Latchem

Dennis A. Murray

Dennis A. Murray

Dennis A. Murray

Paul Fromson

Paul Fromson

Paul Fromson

Paul Fromson

Dennis A. Murray

Dennis A. Murray

Dennis A. Murray

Dennis A. Murray

Dennis A. Murray

Dennis A. Murray

Paul Fromson

Paul Fromson

Paul Fromson

Paul Fromson

Paul Fromson

Paul Fromson

Paul Fromson

Paul Fromson

Paul Fromson

Paul Fromson

Paul Fromson

Paul Fromson

Paul Fromson

Paul Fromson

Paul Fromson

Paul Fromson

Paul Fromson

Paul Fromson

Paul Fromson $\begin{array}{llll}\text { M } & \text { T } & \text { R } & \text { Section Priority }\end{array}$

$\begin{array}{lllll}\text { FSW } & 6 & 8 & 18 & 15\end{array}$

$\begin{array}{lllll}\text { FSW } & 6 & 8 & 19 & 15\end{array}$

$\begin{array}{lllll}\text { FSW } & 6 & 8 & 20 & 15\end{array}$

$\begin{array}{lllll}\text { FSW } & 6 & 8 & 21 & 15\end{array}$

$\begin{array}{lllll}\text { FSW } & 6 & 8 & 25 & 30\end{array}$

$\begin{array}{lllll}\text { FSW } & 6 & 8 & 26 & 30\end{array}$

$\begin{array}{lllll}\text { FSW } & 6 & 8 & 27 & 30\end{array}$

$\begin{array}{lllll}\text { FSW } & 6 & 8 & 28 & 15\end{array}$

$\begin{array}{lllll}\text { FSW } & 6 & 8 & 28 & 30\end{array}$

$\begin{array}{lllll}\text { FSW } & 6 & 8 & 29 & 15\end{array}$

$\begin{array}{lllll}\text { FSW } & 6 & 8 & 29 & 30\end{array}$

$\begin{array}{lllll}\text { FSW } & 6 & 8 & 30 & 15\end{array}$

$\begin{array}{lllll}\text { FSW } & 6 & 8 & 31 & 15\end{array}$

$\begin{array}{lllll}\text { FSW } & 6 & 8 & 32 & 15\end{array}$

$\begin{array}{lllll}\text { FSW } & 6 & 8 & 33 & 15\end{array}$

$\begin{array}{lllll}\text { FSW } & 6 & 8 & 33 & 30\end{array}$

$\begin{array}{lllll}\text { FSW } & 6 & 8 & 34 & 30\end{array}$

$\begin{array}{lllll}\text { FSW } & 6 & 8 & 35 & 30\end{array}$

$\begin{array}{lllll}\text { FSW } & 6 & 8 & 36 & 30\end{array}$

$\begin{array}{lllll}\text { FSW } & 7 & 7 & 1 & 15\end{array}$

$\begin{array}{lllll}\text { FSW } & 7 & 7 & 2 & 15\end{array}$

$\begin{array}{lllll}\text { FSW } & 7 & 7 & 3 & 15\end{array}$

$\begin{array}{lllll}\text { FSW } & 7 & 7 & 4 & 34\end{array}$

$\begin{array}{lllll}\text { FSW } & 7 & 7 & 5 & 34\end{array}$

$\begin{array}{lllll}\text { FSW } & 7 & 7 & 6 & 34\end{array}$

$\begin{array}{lllll}\text { FSW } & 7 & 7 & 9 & 34\end{array}$

$\begin{array}{lllll}\text { FSW } & 7 & 7 & 10 & 15\end{array}$

$\begin{array}{lllll}\text { FSW } & 7 & 7 & 11 & 15\end{array}$

$\begin{array}{lllll}\text { FSW } & 7 & 7 & 12 & 15\end{array}$

$\begin{array}{lllll}\text { FSW } & 7 & 7 & 13 & 15\end{array}$

$\begin{array}{lllll}\text { FSW } & 7 & 7 & 14 & 15\end{array}$

$\begin{array}{lllll}\text { FSW } & 7 & 7 & 15 & 15\end{array}$

$\begin{array}{lllll}\text { FSW } & 7 & 7 & 16 & 34\end{array}$

$\begin{array}{lllll}\text { FSW } & 7 & 7 & 20 & 34\end{array}$

$\begin{array}{lllll}\text { FSW } & 7 & 7 & 21 & 34\end{array}$

$\begin{array}{lllll}\text { FSW } & 7 & 7 & 22 & 34\end{array}$

$\begin{array}{lllll}\text { FSW } & 7 & 7 & 23 & 34\end{array}$

$\begin{array}{lllll}\text { FSW } & 7 & 7 & 24 & 34\end{array}$

$\begin{array}{lllll}\text { FSW } & 7 & 7 & 25 & 34\end{array}$

$\begin{array}{lllll}\text { FSW } & 7 & 7 & 26 & 34\end{array}$

$\begin{array}{lllll}\text { FSW } & 7 & 7 & 27 & 34\end{array}$

$\begin{array}{lllll}\text { FSW } & 7 & 7 & 28 & 34\end{array}$

$\begin{array}{lllll}\text { FSW } & 7 & 7 & 29 & 34\end{array}$

$\begin{array}{lllll}\text { FSW } & 7 & 7 & 30 & 34\end{array}$

$\begin{array}{lllll}\text { FSW } & 7 & 7 & 31 & 34\end{array}$

$\begin{array}{lllll}\text { FSW } & 7 & 7 & 32 & 34\end{array}$

$\begin{array}{lllll}\text { FSW } & 7 & 7 & 33 & 34\end{array}$

$\begin{array}{lllll}\text { FSW } & 7 & 7 & 34 & 34\end{array}$

$\begin{array}{lllll}\text { FSW } & 7 & 7 & 35 & 34\end{array}$

$\begin{array}{lllll}\text { FSW } & 7 & 7 & 36 & 34\end{array}$

$\begin{array}{lllll}\text { FSW } & 7 & 8 & 1 & 34\end{array}$ 


\section{STATE LAND APPLIED FOR UNDER SHALLOW NATURAL GAS LEASING PROGRAM}

\begin{tabular}{|c|c|c|c|c|c|}
\hline Applicant & $\mathbf{M}$ & $\mathbf{T}$ & $\mathbf{R}$ & Section & Priority \\
\hline Paul Fromson & FSW & 7 & 8 & 2 & 34 \\
\hline Paul Fromson & FSW & 7 & 8 & 3 & 34 \\
\hline Paul Fromson & FSW & 7 & 8 & 4 & 34 \\
\hline Paul Fromson & FSW & 7 & 8 & 5 & 34 \\
\hline Paul Fromson & FSW & 7 & 8 & 6 & 34 \\
\hline Paul Fromson & FSW & 7 & 8 & 7 & 34 \\
\hline Paul Fromson & FSW & 7 & 8 & 8 & 34 \\
\hline Paul Fromson & FSW & 7 & 8 & 9 & 34 \\
\hline Paul Fromson & FSW & 7 & 8 & 10 & 34 \\
\hline Paul Fromson & FSW & 7 & 8 & 11 & 34 \\
\hline Paul Fromson & FSW & 7 & 8 & 12 & 34 \\
\hline Paul Fromson & FSW & 7 & 8 & 13 & 34 \\
\hline Paul Fromson & FSW & 7 & 8 & 14 & 34 \\
\hline Paul Fromson & FSW & 7 & 8 & 15 & 34 \\
\hline Paul Fromson & FSW & 7 & 8 & 22 & 34 \\
\hline Paul Fromson & FSW & 7 & 8 & 23 & 34 \\
\hline Paul Fromson & FSW & 7 & 8 & 24 & 34 \\
\hline Paul Fromson & FSW & 7 & 8 & 25 & 34 \\
\hline Paul Fromson & FSW & 7 & 8 & 26 & 34 \\
\hline Paul Fromson & FSW & 7 & 8 & 27 & 34 \\
\hline Paul Fromson & FSW & 7 & 8 & 32 & 34 \\
\hline Paul Fromson & FSW & 7 & 8 & 33 & 34 \\
\hline Paul Fromson & FSW & 7 & 8 & 34 & 34 \\
\hline Paul Fromson & FSW & 7 & 8 & 35 & 34 \\
\hline Paul Fromson & FSW & 7 & 8 & 36 & 34 \\
\hline Paul Fromson & FSW & 8 & 8 & 1 & 34 \\
\hline Paul Fromson & FSW & 8 & 8 & 2 & 34 \\
\hline Paul Fromson & FSW & 8 & 8 & 3 & 34 \\
\hline Paul Fromson & FSW & 8 & 8 & 4 & 34 \\
\hline Paul Fromson & FSW & 8 & 8 & 7 & 34 \\
\hline Paul Fromson & FSW & 8 & 8 & 8 & 34 \\
\hline Paul Fromson & FSW & 8 & 8 & 9 & 34 \\
\hline Paul Fromson & FSW & 8 & 8 & 10 & 34 \\
\hline Paul Fromson & FSW & 8 & 8 & 11 & 34 \\
\hline Paul Fromson & FSW & 8 & 8 & 12 & 34 \\
\hline Paul Fromson & FSW & 8 & 8 & 13 & 34 \\
\hline Paul Fromson & FSW & 8 & 8 & 14 & 34 \\
\hline Paul Fromson & FSW & 8 & 8 & 15 & 34 \\
\hline Paul Fromson & FSW & 8 & 8 & 16 & 34 \\
\hline Paul Fromson & FSW & 8 & 8 & 17 & 34 \\
\hline Paul Fromson & FSW & 8 & 8 & 18 & 34 \\
\hline Paul Fromson & FSW & 8 & 8 & 19 & 34 \\
\hline Paul Fromson & FSW & 8 & 8 & 20 & 34 \\
\hline Cominco Alaska Incorporated & KNW & 31 & 19 & 1 & 3 \\
\hline NANA Dev. Corp. & KNW & 31 & 19 & 1 & 36 \\
\hline Cominco Alaska Incorporated & KNW & 31 & 19 & 2 & 3 \\
\hline NANA Dev. Corp. & KNW & 31 & 19 & 2 & 36 \\
\hline Cominco Alaska Incorporated & KNW & 31 & 19 & 3 & 3 \\
\hline NANA Dev. Corp. & KNW & 31 & 19 & 3 & 36 \\
\hline Cominco Alaska Incorporated & KNW & 31 & 19 & 10 & 3 \\
\hline
\end{tabular}




\section{STATE LAND APPLIED FOR UNDER SHALLOW NATURAL GAS LEASING PROGRAM}

\section{Applicant}

NANA Dev. Corp.

Cominco Alaska Incorporated

NANA Dev. Corp.

Cominco Alaska Incorporated

NANA Dev. Corp.

Cominco Alaska Incorporated

NANA Dev. Corp.

Cominco Alaska Incorporated

NANA Dev. Corp.

Cominco Alaska Incorporated

NANA Dev. Corp.

Cominco Alaska Incorporated

NANA Dev. Corp.

Cominco Alaska Incorporated

NANA Dev. Corp.

Cominco Alaska Incorporated

NANA Dev. Corp.

Cominco Alaska Incorporated

NANA Dev. Corp.

Cominco Alaska Incorporated

NANA Dev. Corp.

Cominco Alaska Incorporated

NANA Dev. Corp.

Cominco Alaska Incorporated

NANA Dev. Corp.

Cominco Alaska Incorporated

NANA Dev. Corp.

Cominco Alaska Incorporated

NANA Dev. Corp.

Cominco Alaska Incorporated

NANA Dev. Corp.

Cominco Alaska Incorporated

NANA Dev. Corp.

Cominco Alaska Incorporated

NANA Dev. Corp.

Cominco Alaska Incorporated

NANA Dev. Corp.

Cominco Alaska Incorporated

NANA Dev. Corp.

Cominco Alaska Incorporated

NANA Dev. Corp.

Cominco Alaska Incorporated

NANA Dev. Corp.

Cominco Alaska Incorporated

NANA Dev. Corp.

Cominco Alaska Incorporated

NANA Dev. Corp.

Cominco Alaska Incorporated

NANA Dev. Corp.

Cominco Alaska Incorporated

NANA Dev. Corp.

\begin{tabular}{|c|c|c|c|c|}
\hline $\mathbf{M}$ & $\mathbf{T}$ & $\mathbf{R}$ & Section & Priority \\
\hline KNW & 31 & 19 & 10 & 36 \\
\hline KNW & 31 & 19 & 11 & 3 \\
\hline KNW & 31 & 19 & 11 & 36 \\
\hline KNW & 31 & 19 & 12 & 3 \\
\hline KNW & 31 & 19 & 12 & 36 \\
\hline KNW & 31 & 19 & 13 & 3 \\
\hline KNW & 31 & 19 & 13 & 36 \\
\hline KNW & 31 & 19 & 14 & 3 \\
\hline KNW & 31 & 19 & 14 & 36 \\
\hline KNW & 32 & 19 & 1 & 3 \\
\hline KNW & 32 & 19 & 1 & 36 \\
\hline KNW & 32 & 19 & 2 & 3 \\
\hline KNW & 32 & 19 & 2 & 36 \\
\hline KNW & 32 & 19 & 3 & 3 \\
\hline KNW & 32 & 19 & 3 & 36 \\
\hline KNW & 32 & 19 & 4 & 3 \\
\hline KNW & 32 & 19 & 4 & 36 \\
\hline KNW & 32 & 19 & 5 & 3 \\
\hline KNW & 32 & 19 & 5 & 36 \\
\hline KNW & 32 & 19 & 8 & 3 \\
\hline KNW & 32 & 19 & 8 & 36 \\
\hline KNW & 32 & 19 & 9 & 3 \\
\hline KNW & 32 & 19 & 9 & 36 \\
\hline KNW & 32 & 19 & 10 & 3 \\
\hline KNW & 32 & 19 & 10 & 36 \\
\hline KNW & 32 & 19 & 11 & 3 \\
\hline KNW & 32 & 19 & 11 & 36 \\
\hline KNW & 32 & 19 & 12 & 3 \\
\hline KNW & 32 & 19 & 12 & 36 \\
\hline KNW & 32 & 19 & 13 & 3 \\
\hline KNW & 32 & 19 & 13 & 36 \\
\hline KNW & 32 & 19 & 14 & 3 \\
\hline KNW & 32 & 19 & 14 & 36 \\
\hline KNW & 32 & 19 & 15 & 3 \\
\hline KNW & 32 & 19 & 15 & 36 \\
\hline KNW & 32 & 19 & 16 & 3 \\
\hline KNW & 32 & 19 & 16 & 36 \\
\hline KNW & 32 & 19 & 17 & 3 \\
\hline KNW & 32 & 19 & 17 & 36 \\
\hline KNW & 32 & 19 & 20 & 3 \\
\hline KNW & 32 & 19 & 20 & 36 \\
\hline KNW & 32 & 19 & 21 & 3 \\
\hline KNW & 32 & 19 & 21 & 36 \\
\hline KNW & 32 & 19 & 22 & 3 \\
\hline KNW & 32 & 19 & 22 & 36 \\
\hline KNW & 32 & 19 & 23 & 3 \\
\hline KNW & 32 & 19 & 23 & 36 \\
\hline KNW & 32 & 19 & 24 & 3 \\
\hline KNW & 32 & 19 & 24 & 36 \\
\hline KNW & 32 & 19 & 25 & 3 \\
\hline KNW & 32 & 19 & 25 & 36 \\
\hline
\end{tabular}




\section{STATE LAND APPLIED FOR UNDER SHALLOW NATURAL GAS LEASING PROGRAM}

\begin{tabular}{|c|c|c|c|c|c|}
\hline Applicant & $\mathbf{M}$ & $\mathbf{T}$ & $\mathbf{R}$ & Section & Priority \\
\hline Cominco Alaska Incorporated & KNW & 32 & 19 & 26 & 3 \\
\hline NANA Dev. Corp. & KNW & 32 & 19 & 26 & 36 \\
\hline Cominco Alaska Incorporated & KNW & 32 & 19 & 27 & 3 \\
\hline NANA Dev. Corp. & KNW & 32 & 19 & 27 & 36 \\
\hline Cominco Alaska Incorporated & KNW & 32 & 19 & 28 & 3 \\
\hline NANA Dev. Corp. & KNW & 32 & 19 & 28 & 36 \\
\hline Cominco Alaska Incorporated & KNW & 32 & 19 & 29 & 3 \\
\hline NANA Dev. Corp. & KNW & 32 & 19 & 29 & 36 \\
\hline Cominco Alaska Incorporated & KNW & 32 & 19 & 34 & 3 \\
\hline NANA Dev. Corp. & KNW & 32 & 19 & 34 & 36 \\
\hline Cominco Alaska Incorporated & KNW & 32 & 19 & 35 & 3 \\
\hline NANA Dev. Corp. & KNW & 32 & 19 & 35 & 36 \\
\hline Cominco Alaska Incorporated & KNW & 32 & 19 & 36 & 3 \\
\hline NANA Dev. Corp. & KNW & 32 & 19 & 36 & 36 \\
\hline Ocean Energy Resources, Inc. & SNE & 17 & 1 & 1 & 6 \\
\hline Ocean Energy Resources, Inc. & SNE & 17 & 1 & 2 & 6 \\
\hline Ocean Energy Resources, Inc. & SNE & 17 & 1 & 3 & 6 \\
\hline Ocean Energy Resources, Inc. & SNE & 17 & 1 & 10 & 6 \\
\hline Ocean Energy Resources, Inc. & SNE & 17 & 1 & 11 & 6 \\
\hline Ocean Energy Resources, Inc. & SNE & 17 & 1 & 12 & 6 \\
\hline Ocean Energy Resources, Inc. & SNE & 17 & 1 & 13 & 6 \\
\hline Ocean Energy Resources, Inc. & SNE & 17 & 1 & 14 & 6 \\
\hline Ocean Energy Resources, Inc. & SNE & 17 & 1 & 15 & 6 \\
\hline Elisabeth M. Hollmann & SNE & 18 & 1 & 1 & 2 \\
\hline John C. Teich & SNE & 18 & 1 & 1 & 7 \\
\hline John P. Hollmann & SNE & 18 & 1 & 1 & 22 \\
\hline Ocean Energy Resources, Inc. & SNE & 18 & 1 & 1 & 6 \\
\hline Shannon G. Latchem & SNE & 18 & 1 & 1 & 30 \\
\hline Elisabeth M. Hollmann & SNE & 18 & 1 & 2 & 2 \\
\hline John C. Teich & SNE & 18 & 1 & 2 & 7 \\
\hline John P. Hollmann & SNE & 18 & 1 & 2 & 22 \\
\hline Ocean Energy Resources, Inc. & SNE & 18 & 1 & 2 & 6 \\
\hline Shannon G. Latchem & SNE & 18 & 1 & 2 & 30 \\
\hline Elisabeth M. Hollmann & SNE & 18 & 1 & 3 & 2 \\
\hline John C. Teich & SNE & 18 & 1 & 3 & 7 \\
\hline John P. Hollmann & SNE & 18 & 1 & 3 & 22 \\
\hline Ocean Energy Resources, Inc. & SNE & 18 & 1 & 3 & 6 \\
\hline Shannon G. Latchem & SNE & 18 & 1 & 3 & 30 \\
\hline John C. Teich & SNE & 18 & 1 & 4 & 7 \\
\hline Lowell R. Thomas & SNE & 18 & 1 & 4 & 14 \\
\hline Ocean Energy Resources, Inc. & SNE & 18 & 1 & 4 & 6 \\
\hline Pamela J. Emery & SNE & 18 & 1 & 4 & 19 \\
\hline Paula J. Mills & SNE & 18 & 1 & 4 & 5 \\
\hline Shannon G. Latchem & SNE & 18 & 1 & 4 & 30 \\
\hline John C. Teich & SNE & 18 & 1 & 5 & 7 \\
\hline Lowell R. Thomas & SNE & 18 & 1 & 5 & 14 \\
\hline Ocean Energy Resources, Inc. & SNE & 18 & 1 & 5 & 6 \\
\hline Pamela J. Emery & SNE & 18 & 1 & 5 & 19 \\
\hline Paula J. Mills & SNE & 18 & 1 & 5 & 5 \\
\hline Shannon G. Latchem & SNE & 18 & 1 & 5 & 30 \\
\hline
\end{tabular}




\section{Applicant}

John C. Teich

Lowell R. Thomas

Ocean Energy Resources, Inc.

Pamela J. Emery

Paula J. Mills

Shannon G. Latchem

John C. Teich

Lowell R. Thomas

Ocean Energy Resources, Inc.

Pamela J. Emery

Paula J. Mills

Shannon G. Latchem

John C. Teich

Lowell R. Thomas

Ocean Energy Resources, Inc.

Pamela J. Emery

Paula J. Mills

Shannon G. Latchem

John C. Teich

Lowell R. Thomas

Ocean Energy Resources, Inc.

Pamela J. Emery

Paula J. Mills

Shannon G. Latchem

Elisabeth M. Hollmann

John C. Teich

John P. Hollmann

Ocean Energy Resources, Inc.

Shannon G. Latchem

Elisabeth M. Hollmann

John C. Teich

John P. Hollmann

Ocean Energy Resources, Inc.

Shannon G. Latchem

Elisabeth M. Hollmann

John C. Teich

John P. Hollmann

Ocean Energy Resources, Inc.

Shannon G. Latchem

Elisabeth M. Hollmann

John C. Teich

John P. Hollmann

Ocean Energy Resources, Inc.

Shannon G. Latchem

Elisabeth M. Hollmann

John C. Teich

John P. Hollmann

Ocean Energy Resources, Inc.

Shannon G. Latchem

Elisabeth M. Hollmann

John C. Teich $\begin{array}{lllll}\text { M } & \text { T } & \text { R } & \text { Section } & \text { Priority }\end{array}$

$\begin{array}{lllll}\text { SNE } & 18 & 1 & 6 & 7\end{array}$

$\begin{array}{lllll}\text { SNE } & 18 & 1 & 6 & 14\end{array}$

$\begin{array}{lllll}\text { SNE } & 18 & 1 & 6 & 6\end{array}$

$\begin{array}{lllll}\text { SNE } & 18 & 1 & 6 & 19\end{array}$

$\begin{array}{lllll}\text { SNE } & 18 & 1 & 6 & 5\end{array}$

$\begin{array}{lllll}\text { SNE } & 18 & 1 & 6 & 30\end{array}$

$\begin{array}{lllll}\text { SNE } & 18 & 1 & 7 & 7\end{array}$

$\begin{array}{lllll}\text { SNE } & 18 & 1 & 7 & 14\end{array}$

$\begin{array}{lllll}\text { SNE } & 18 & 1 & 7 & 6\end{array}$

$\begin{array}{lllll}\text { SNE } & 18 & 1 & 7 & 19\end{array}$

$\begin{array}{lllll}\text { SNE } & 18 & 1 & 7 & 5\end{array}$

$\begin{array}{lllll}\text { SNE } & 18 & 1 & 7 & 30\end{array}$

SNE 18

SNE 18

SNE 18

SNE 18

SNE 18

SNE 18

SNE 18

SNE 18

SNE 18

SNE 18

SNE 18

SNE 18

SNE 18

SNE 18

SNE 18

SNE 18

SNE 18

SNE 18

SNE 18

SNE 18

SNE 18

SNE 18

SNE 18

SNE 18

SNE 18

SNE 18

SNE 18

SNE 18

SNE 18

SNE 18

SNE 18

SNE 18

SNE 18

SNE $\quad 18$

SNE 18

SNE 18

SNE 18

SNE 18

SNE 18 


\section{STATE LAND APPLIED FOR UNDER SHALLOW NATURAL GAS LEASING PROGRAM}

\begin{tabular}{|c|c|c|c|c|c|}
\hline Applicant & M & $\mathbf{T}$ & $\mathbf{R}$ & Section & Priority \\
\hline John P. Hollmann & SNE & 18 & 1 & 15 & 22 \\
\hline Ocean Energy Resources, Inc. & SNE & 18 & 1 & 15 & 6 \\
\hline Shannon G. Latchem & SNE & 18 & 1 & 15 & 30 \\
\hline John C. Teich & SNE & 18 & 1 & 16 & 7 \\
\hline Lowell R. Thomas & SNE & 18 & 1 & 16 & 14 \\
\hline Ocean Energy Resources, Inc. & SNE & 18 & 1 & 16 & 6 \\
\hline Pamela J. Emery & SNE & 18 & 1 & 16 & 19 \\
\hline Paula J. Mills & SNE & 18 & 1 & 16 & 5 \\
\hline Shannon G. Latchem & SNE & 18 & 1 & 16 & 30 \\
\hline John C. Teich & SNE & 18 & 1 & 17 & 7 \\
\hline Lowell R. Thomas & SNE & 18 & 1 & 17 & 14 \\
\hline Ocean Energy Resources, Inc. & SNE & 18 & 1 & 17 & 6 \\
\hline Pamela J. Emery & SNE & 18 & 1 & 17 & 19 \\
\hline Paula J. Mills & SNE & 18 & 1 & 17 & 5 \\
\hline Shannon G. Latchem & SNE & 18 & 1 & 17 & 30 \\
\hline John C. Teich & SNE & 18 & 1 & 18 & 7 \\
\hline Lowell R. Thomas & SNE & 18 & 1 & 18 & 14 \\
\hline Ocean Energy Resources, Inc. & SNE & 18 & 1 & 18 & 6 \\
\hline Pamela J. Emery & SNE & 18 & 1 & 18 & 19 \\
\hline Paula J. Mills & SNE & 18 & 1 & 18 & 5 \\
\hline Shannon G. Latchem & SNE & 18 & 1 & 18 & 30 \\
\hline Ocean Energy Resources, Inc. & SNE & 18 & 1 & 19 & 6 \\
\hline Ocean Energy Resources, Inc. & SNE & 18 & 1 & 20 & 6 \\
\hline Ocean Energy Resources, Inc. & SNE & 18 & 1 & 21 & 6 \\
\hline Elisabeth M. Hollmann & SNE & 18 & 1 & 22 & 2 \\
\hline John P. Hollmann & SNE & 18 & 1 & 22 & 22 \\
\hline Ocean Energy Resources, Inc. & SNE & 18 & 1 & 22 & 6 \\
\hline Elisabeth M. Hollmann & SNE & 18 & 1 & 23 & 2 \\
\hline John P. Hollmann & SNE & 18 & 1 & 23 & 22 \\
\hline Ocean Energy Resources, Inc. & SNE & 18 & 1 & 23 & 6 \\
\hline Elisabeth M. Hollmann & SNE & 18 & 1 & 24 & 2 \\
\hline John P. Hollmann & SNE & 18 & 1 & 24 & 22 \\
\hline Ocean Energy Resources, Inc. & SNE & 18 & 1 & 24 & 6 \\
\hline Elisabeth M. Hollmann & SNE & 18 & 1 & 25 & 2 \\
\hline John P. Hollmann & SNE & 18 & 1 & 25 & 22 \\
\hline Ocean Energy Resources, Inc. & SNE & 18 & 1 & 25 & 6 \\
\hline Elisabeth M. Hollmann & SNE & 18 & 1 & 26 & 2 \\
\hline John P. Hollmann & SNE & 18 & 1 & 26 & 22 \\
\hline Ocean Energy Resources, Inc. & SNE & 18 & 1 & 26 & 6 \\
\hline Elisabeth M. Hollmann & SNE & 18 & 1 & 27 & 2 \\
\hline John P. Hollmann & SNE & 18 & 1 & 27 & 22 \\
\hline Ocean Energy Resources, Inc. & SNE & 18 & 1 & 27 & 6 \\
\hline Ocean Energy Resources, Inc. & SNE & 18 & 1 & 28 & 6 \\
\hline Ocean Energy Resources, Inc. & SNE & 18 & 1 & 29 & 6 \\
\hline Ocean Energy Resources, Inc. & SNE & 18 & 1 & 30 & 6 \\
\hline Ocean Energy Resources, Inc. & SNE & 18 & 1 & 31 & 6 \\
\hline Ocean Energy Resources, Inc. & SNE & 18 & 1 & 32 & 6 \\
\hline Ocean Energy Resources, Inc. & SNE & 18 & 1 & 33 & 6 \\
\hline Elisabeth M. Hollmann & SNE & 18 & 1 & 34 & 2 \\
\hline John P. Hollmann & SNE & 18 & 1 & 34 & 22 \\
\hline Ocean Energy Resources, Inc. & SNE & 18 & 1 & 34 & 6 \\
\hline
\end{tabular}




\section{STATE LAND APPLIED FOR UNDER SHALLOW NATURAL GAS LEASING PROGRAM}

\begin{tabular}{|c|c|c|c|c|c|}
\hline Applicant & M & $\mathbf{T}$ & $\mathbf{R}$ & Section & Priority \\
\hline Elisabeth M. Hollmann & SNE & 18 & 1 & 35 & 2 \\
\hline John P. Hollmann & SNE & 18 & 1 & 35 & 22 \\
\hline Ocean Energy Resources, Inc. & SNE & 18 & 1 & 35 & 6 \\
\hline Elisabeth M. Hollmann & SNE & 18 & 1 & 36 & 2 \\
\hline John P. Hollmann & SNE & 18 & 1 & 36 & 22 \\
\hline Ocean Energy Resources, Inc. & SNE & 18 & 1 & 36 & 6 \\
\hline Elisabeth M. Hollmann & SNE & 18 & 2 & 1 & 2 \\
\hline John P. Hollmann & SNE & 18 & 2 & 1 & 22 \\
\hline Kenneth A. Schlenker & SNE & 18 & 2 & 1 & 18 \\
\hline Elisabeth M. Hollmann & SNE & 18 & 2 & 2 & 2 \\
\hline John P. Hollmann & SNE & 18 & 2 & 2 & 22 \\
\hline Elisabeth M. Hollmann & SNE & 18 & 2 & 3 & 2 \\
\hline John P. Hollmann & SNE & 18 & 2 & 3 & 22 \\
\hline Shannon G. Latchem & SNE & 18 & 2 & 3 & 30 \\
\hline Elisabeth M. Hollmann & SNE & 18 & 2 & 4 & 2 \\
\hline John P. Hollmann & SNE & 18 & 2 & 4 & 22 \\
\hline Shannon G. Latchem & SNE & 18 & 2 & 4 & 30 \\
\hline Elisabeth M. Hollmann & SNE & 18 & 2 & 5 & 2 \\
\hline John P. Hollmann & SNE & 18 & 2 & 5 & 22 \\
\hline Shannon G. Latchem & SNE & 18 & 2 & 5 & 30 \\
\hline Elisabeth M. Hollmann & SNE & 18 & 2 & 6 & 2 \\
\hline John P. Hollmann & SNE & 18 & 2 & 6 & 22 \\
\hline Shannon G. Latchem & SNE & 18 & 2 & 6 & 30 \\
\hline Elisabeth M. Hollmann & SNE & 18 & 2 & 7 & 2 \\
\hline John P. Hollmann & SNE & 18 & 2 & 7 & 22 \\
\hline Shannon G. Latchem & SNE & 18 & 2 & 7 & 30 \\
\hline Elisabeth M. Hollmann & SNE & 18 & 2 & 8 & 2 \\
\hline John P. Hollmann & SNE & 18 & 2 & 8 & 22 \\
\hline Shannon G. Latchem & SNE & 18 & 2 & 8 & 30 \\
\hline Elisabeth M. Hollmann & SNE & 18 & 2 & 9 & 2 \\
\hline John P. Hollmann & SNE & 18 & 2 & 9 & 22 \\
\hline Shannon G. Latchem & SNE & 18 & 2 & 9 & 30 \\
\hline Elisabeth M. Hollmann & SNE & 18 & 2 & 10 & 2 \\
\hline John P. Hollmann & SNE & 18 & 2 & 10 & 22 \\
\hline Elisabeth M. Hollmann & SNE & 18 & 2 & 11 & 2 \\
\hline John P. Hollmann & SNE & 18 & 2 & 11 & 22 \\
\hline Kenneth A. Schlenker & SNE & 18 & 2 & 11 & 18 \\
\hline Elisabeth M. Hollmann & SNE & 18 & 2 & 12 & 2 \\
\hline John P. Hollmann & SNE & 18 & 2 & 12 & 22 \\
\hline Kenneth A. Schlenker & SNE & 18 & 2 & 12 & 18 \\
\hline Elisabeth M. Hollmann & SNE & 18 & 2 & 13 & 2 \\
\hline John P. Hollmann & SNE & 18 & 2 & 13 & 22 \\
\hline Kenneth A. Schlenker & SNE & 18 & 2 & 13 & 18 \\
\hline Elisabeth M. Hollmann & SNE & 18 & 2 & 14 & 2 \\
\hline John P. Hollmann & SNE & 18 & 2 & 14 & 22 \\
\hline Kenneth A. Schlenker & SNE & 18 & 2 & 14 & 18 \\
\hline Elisabeth M. Hollmann & SNE & 18 & 2 & 15 & 2 \\
\hline John P. Hollmann & SNE & 18 & 2 & 15 & 22 \\
\hline Kenneth A. Schlenker & SNE & 18 & 2 & 15 & 18 \\
\hline Elisabeth M. Hollmann & SNE & 18 & 2 & 16 & 2 \\
\hline John P. Hollmann & SNE & 18 & 2 & 16 & 22 \\
\hline
\end{tabular}




\begin{tabular}{|c|c|c|c|c|c|}
\hline Applicant & $\mathbf{M}$ & $\mathbf{T}$ & $\mathbf{R}$ & Section & Priority \\
\hline Elisabeth M. Hollmann & SNE & 18 & 2 & 17 & 2 \\
\hline John P. Hollmann & SNE & 18 & 2 & 17 & 22 \\
\hline Shannon G. Latchem & SNE & 18 & 2 & 17 & 30 \\
\hline Elisabeth M. Holimann & SNE & 18 & 2 & 18 & 2 \\
\hline John P. Hollmann & SNE & 18 & 2 & 18 & 22 \\
\hline Shannon G. Latchem & SNE & 18 & 2 & 18 & 30 \\
\hline Elisabeth M. Hollmann & SNE & 18 & 2 & 19 & 2 \\
\hline John P. Hollmann & SNE & 18 & 2 & 19 & 22 \\
\hline Shannon G. Latchem & SNE & 18 & 2 & 19 & 30 \\
\hline Elisabeth M. Hollmann & SNE & 18 & 2 & 20 & 2 \\
\hline John P. Hollmann & SNE & 18 & 2 & 20 & 22 \\
\hline Shannon G. Latchem & SNE & 18 & 2 & 20 & 30 \\
\hline Elisabeth M. Hollmann & SNE & 18 & 2 & 21 & 2 \\
\hline John P. Hollmann & SNE & 18 & 2 & 21 & 22 \\
\hline Kenneth A. Schlenker & SNE & 18 & 2 & 21 & 18 \\
\hline Kenneth A. Schlenker & SNE & 18 & 2 & 22 & 18 \\
\hline Pamela J. Emery & SNE & 18 & 2 & 22 & 19 \\
\hline Pamela J. Emery & SNE & 18 & 2 & 23 & 19 \\
\hline Kenneth A. Schlenker & SNE & 18 & 2 & 24 & 18 \\
\hline Pamela J. Emery & SNE & 18 & 2 & 24 & 19 \\
\hline Pamela J. Emery & SNE & 18 & 2 & 25 & 19 \\
\hline Pamela J. Emery & SNE & 18 & 2 & 26 & 19 \\
\hline Pamela J. Emery & SNE & 18 & 2 & 27 & 19 \\
\hline Elisabeth M. Hollmann & SNE & 18 & 2 & 28 & 2 \\
\hline John P. Hollmann & SNE & 18 & 2 & 28 & 22 \\
\hline Elisabeth M. Hollmann & SNE & 18 & 2 & 29 & 2 \\
\hline John P. Hollmann & SNE & 18 & 2 & 29 & 22 \\
\hline Shannon G. Latchem & SNE & 18 & 2 & 29 & 30 \\
\hline Elisabeth M. Hollmann & SNE & 18 & 2 & 30 & 2 \\
\hline John P. Hollmann & SNE & 18 & 2 & 30 & 22 \\
\hline Elisabeth M. Hollmann & SNE & 18 & 2 & 31 & 2 \\
\hline John P. Hollmann & SNE & 18 & 2 & 31 & 22 \\
\hline Elisabeth M. Hollmann & SNE & 18 & 2 & 32 & 2 \\
\hline John P. Hollmann & SNE & 18 & 2 & 32 & 22 \\
\hline Elisabeth M. Hollmann & SNE & 18 & 2 & 33 & 2 \\
\hline John P. Hollmann & SNE & 18 & 2 & 33 & 22 \\
\hline Pamela J. Emery & SNE & 18 & 2 & 34 & 19 \\
\hline Pamela J. Emery & SNE & 18 & 2 & 35 & 19 \\
\hline Pamela J. Emery & SNE & 18 & 2 & 36 & 19 \\
\hline Pamela J. Emery & SNE & 18 & 3 & 4 & 19 \\
\hline Pamela J. Emery & SNE & 18 & 3 & 5 & 19 \\
\hline Pamela J. Emery & SNE & 18 & 3 & 6 & 19 \\
\hline Pamela J. Emery & SNE & 18 & 3 & 7 & 19 \\
\hline Pamela J. Emery & SNE & 18 & 3 & 8 & 19 \\
\hline Pamela J. Emery & SNE & 18 & 3 & 9 & 19 \\
\hline Pamela J. Emery & SNE & 18 & 3 & 16 & 19 \\
\hline Pamela J. Emery & SNE & 18 & 3 & 17 & 19 \\
\hline Pamela J. Emery & SNE & 18 & 3 & 18 & 19 \\
\hline Elisabeth M. Hollmann & SNE & 19 & 1 & 14 & 2 \\
\hline John P. Hollmann & SNE & 19 & 1 & 14 & 22 \\
\hline Elisabeth M. Hollmann & SNE & 19 & 1 & 23 & 2 \\
\hline
\end{tabular}




\section{STATE LAND APPLIED FOR UNDER SHALLOW NATURAL GAS LEASING PROGRAM}

\begin{tabular}{|c|c|c|c|c|c|}
\hline Applicant & $\mathbf{M}$ & $T$ & $\mathbf{R}$ & Section & Priority \\
\hline John P. Hollmann & SNE & 19 & 1 & 23 & 22 \\
\hline Elisabeth M. Hollmann & SNE & 19 & 1 & 24 & 2 \\
\hline Growth Resources, Ltd & SNE & 19 & 1 & 24 & 13 \\
\hline John P. Hollmann & SNE & 19 & 1 & 24 & 22 \\
\hline Shannon G. Latchem & SNE & 19 & 1 & 24 & 30 \\
\hline Elisabeth M. Hollmann & SNE & 19 & 1 & 25 & 2 \\
\hline Growth Resources, Ltd & SNE & 19 & 1 & 25 & 13 \\
\hline John P. Hollmann & SNE & 19 & 1 & 25 & 22 \\
\hline Shannon G. Latchem & SNE & 19 & 1 & 25 & 30 \\
\hline Elisabeth M. Hollmann & SNE & 19 & 1 & 26 & 2 \\
\hline Growth Resources, Ltd & SNE & 19 & 1 & 26 & 13 \\
\hline John P. Hollmann & SNE & 19 & 1 & 26 & 22 \\
\hline Shannon G. Latchem & SNE & 19 & 1 & 26 & 30 \\
\hline Elisabeth M. Hollmann & SNE & 19 & 1 & 27 & 2 \\
\hline Growth Resources, Ltd & SNE & 19 & 1 & 27 & 13 \\
\hline John P. Hollmann & SNE & 19 & 1 & 27 & 22 \\
\hline Growth Resources, Ltd & SNE & 19 & 1 & 28 & 13 \\
\hline Lowell R. Thomas & SNE & 19 & 1 & 28 & 14 \\
\hline Pamela J. Emery & SNE & 19 & 1 & 28 & 19 \\
\hline Paula J. Mills & SNE & 19 & 1 & 28 & 5 \\
\hline Growth Resources, Ltd & SNE & 19 & 1 & 29 & 13 \\
\hline Lowell R. Thomas & SNE & 19 & 1 & 29 & 14 \\
\hline Pamela J. Emery & SNE & 19 & 1 & 29 & 19 \\
\hline Paula J. Mills & SNE & 19 & 1 & 29 & 5 \\
\hline Growth Resources, Ltd & SNE & 19 & 1 & 30 & 13 \\
\hline Lowell R. Thomas & SNE & 19 & 1 & 30 & 14 \\
\hline Pamela J. Emery & SNE & 19 & 1 & 30 & 19 \\
\hline Paula J. Mills & SNE & 19 & 1 & 30 & 5 \\
\hline Growth Resources, Ltd & SNE & 19 & 1 & 31 & 13 \\
\hline Lowell R. Thomas & SNE & 19 & 1 & 31 & 14 \\
\hline Pamela J. Emery & SNE & 19 & 1 & 31 & 19 \\
\hline Paula J. Mills & SNE & 19 & 1 & 31 & 5 \\
\hline Growth Resources, Ltd & SNE & 19 & 1 & 32 & 13 \\
\hline Lowell R. Thomas & SNE & 19 & 1 & 32 & 14 \\
\hline Pamela J. Emery & SNE & 19 & 1 & 32 & 19 \\
\hline Paula J. Mills & SNE & 19 & 1 & 32 & 5 \\
\hline Growth Resources, Ltd & SNE & 19 & 1 & 33 & 13 \\
\hline Lowell R. Thomas & SNE & 19 & 1 & 33 & 14 \\
\hline Pamela J. Emery & SNE & 19 & 1 & 33 & 19 \\
\hline Paula J. Mills & SNE & 19 & 1 & 33 & 5 \\
\hline Elisabeth M. Hollmann & SNE & 19 & 1 & 34 & 2 \\
\hline Growth Resources, Ltd & SNE & 19 & 1 & 34 & 13 \\
\hline John P. Hollmann & SNE & 19 & 1 & 34 & 22 \\
\hline Elisabeth M. Hollmann & SNE & 19 & 1 & 35 & 2 \\
\hline Growth Resources, Ltd & SNE & 19 & 1 & 35 & 13 \\
\hline John P. Hollmann & SNE & 19 & 1 & 35 & 22 \\
\hline Elisabeth M. Hollmann & SNE & 19 & 1 & 36 & 2 \\
\hline Growth Resources, Ltd & SNE & 19 & 1 & 36 & 13 \\
\hline John P. Hollmann & SNE & 19 & 1 & 36 & 22 \\
\hline Shannon G. Latchem & SNE & 19 & 1 & 36 & 30 \\
\hline Kenneth A. Schlenker & SNE & 19 & 2 & 12 & 18 \\
\hline
\end{tabular}




\section{Applicant}

Kenneth A. Schlenker

Pamela J. Emery

Kenneth A. Schlenker

Elisabeth M. Hollmann

Growth Resources, Ltd

John P. Hollmann

Shannon G. Latchem

Elisabeth M. Hollmann

Growth Resources, Ltd

John P. Hollmann

Shannon G. Latchem

Elisabeth M. Hollmann

Growth Resources, Ltd

John P. Hollmann

Shannon G. Latchem

Elisabeth M. Hollmann

Growth Resources, Ltd

John P. Hollmann

Shannon G. Latchem

Elisabeth M. Hollmann

John P. Hollmann

Kenneth A. Schlenker

Shannon G. Latchem

Elisabeth M. Holimann

John P. Hollmann

Kenneth A. Schlenker

Shannon G. Latchem

Elisabeth M. Hollmann

John P. Hollmann

Kenneth A. Schlenker

Shannon G. Latchem

Elisabeth M. Hollmann

John P. Hollmann

Kenneth A. Schlenker

Shannon G. Latchem

Elisabeth M. Hollmann

Growth Resources, Ltd

John P. Hollmann

Shannon G. Latchem

Elisabeth M. Hollmann

Growth Resources, Ltd

John P. Hollmann

Shannon G. Latchem

Elisabeth M. Hollmann

Growth Resources, Ltd

John P. Hollmann

Shannon G. Latchem

Elisabeth M. Hollmann

Growth Resources, Ltd

John P. Hollmann

Shannon G. Latchem

\begin{tabular}{|c|c|c|c|c|}
\hline $\mathbf{M}$ & $\mathrm{T}$ & $\mathbf{R}$ & Section & Priority \\
\hline SNE & 19 & 2 & 13 & 18 \\
\hline SNE & 19 & 2 & 13 & 19 \\
\hline SNE & 19 & 2 & 14 & 18 \\
\hline SNE & 19 & 2 & 19 & 2 \\
\hline SNE & 19 & 2 & 19 & 13 \\
\hline SNE & 19 & 2 & 19 & 22 \\
\hline SNE & 19 & 2 & 19 & 30 \\
\hline SNE & 19 & 2 & 20 & 2 \\
\hline SNE & 19 & 2 & 20 & 13 \\
\hline SNE & 19 & 2 & 20 & 22 \\
\hline SNE & 19 & 2 & 20 & 30 \\
\hline SNE & 19 & 2 & 21 & 2 \\
\hline SNE & 19 & 2 & 21 & 13 \\
\hline SNE & 19 & 2 & 21 & 22 \\
\hline SNE & 19 & 2 & 21 & 30 \\
\hline SNE & 19 & 2 & 22 & 2 \\
\hline SNE & 19 & 2 & 22 & 13 \\
\hline SNE & 19 & 2 & 22 & 22 \\
\hline SNE & 19 & 2 & 22 & 30 \\
\hline SNE & 19 & 2 & 23 & 2 \\
\hline SNE & 19 & 2 & 23 & 22 \\
\hline SNE & 19 & 2 & 23 & 18 \\
\hline SNE & 19 & 2 & 23 & 30 \\
\hline SNE & 19 & 2 & 24 & 2 \\
\hline SNE & 19 & 2 & 24 & 22 \\
\hline SNE & 19 & 2 & 24 & 18 \\
\hline SNE & 19 & 2 & 24 & 30 \\
\hline SNE & 19 & 2 & 25 & 2 \\
\hline SNE & 19 & 2 & 25 & 22 \\
\hline SNE & 19 & 2 & 25 & 18 \\
\hline SNE & 19 & 2 & 25 & 30 \\
\hline SNE & 19 & 2 & 26 & 2 \\
\hline SNE & 19 & 2 & 26 & 22 \\
\hline SNE & 19 & 2 & 26 & 18 \\
\hline SNE & 19 & 2 & 26 & 30 \\
\hline SNE & 19 & 2 & 27 & 2 \\
\hline SNE & 19 & 2 & 27 & 13 \\
\hline SNE & 19 & 2 & 27 & 22 \\
\hline SNE & 19 & 2 & 27 & 30 \\
\hline SNE & 19 & 2 & 28 & 2 \\
\hline SNE & 19 & 2 & 28 & 13 \\
\hline SNE & 19 & 2 & 28 & 22 \\
\hline SNE & 19 & 2 & 28 & 30 \\
\hline SNE & 19 & 2 & 29 & 2 \\
\hline SNE & 19 & 2 & 29 & 13 \\
\hline SNE & 19 & 2 & 29 & 22 \\
\hline SNE & 19 & 2 & 29 & 30 \\
\hline SNE & 19 & 2 & 30 & 2 \\
\hline SNE & 19 & 2 & 30 & 13 \\
\hline SNE & 19 & 2 & 30 & 22 \\
\hline SNE & 19 & 2 & 30 & 30 \\
\hline
\end{tabular}


STATE LAND APPLIED FOR UNDER SHALLOW NATURAL GAS LEASING PROGRAM

\begin{tabular}{|c|c|c|c|c|c|}
\hline Applicant & $\mathbf{M}$ & $\mathrm{T}$ & $\mathbf{R}$ & Section & Priority \\
\hline Elisabeth M. Hollmann & SNE & 19 & 2 & 31 & 2 \\
\hline Growth Resources, Ltd & SNE & 19 & 2 & 31 & 13 \\
\hline John P. Hollmann & SNE & 19 & 2 & 31 & 22 \\
\hline Shannon G. Latchem & SNE & 19 & 2 & 31 & 30 \\
\hline Elisabeth M. Hollmann & SNE & 19 & 2 & 32 & 2 \\
\hline Growth Resources, Ltd & SNE & 19 & 2 & 32 & 13 \\
\hline John P. Hollmann & SNE & 19 & 2 & 32 & 22 \\
\hline Shannon G. Latchem & SNE & 19 & 2 & 32 & 30 \\
\hline Elisabeth M. Hollmann & SNE & 19 & 2 & 33 & 2 \\
\hline Growth Resources, Ltd & SNE & 19 & 2 & 33 & 13 \\
\hline John P. Hollmann & SNE & 19 & 2 & 33 & 22 \\
\hline Shannon G. Latchem & SNE & 19 & 2 & 33 & 30 \\
\hline Elisabeth M. Hollmann & SNE & 19 & 2 & 34 & 2 \\
\hline Growth Resources, Ltd & SNE & 19 & 2 & 34 & 13 \\
\hline John P. Hollmann & SNE & 19 & 2 & 34 & 22 \\
\hline Shannon G. Latchem & SNE & 19 & 2 & 34 & 30 \\
\hline Elisabeth M. Hollmann & SNE & 19 & 2 & 35 & 2 \\
\hline John P. Hollmann & SNE & 19 & 2 & 35 & 22 \\
\hline Kenneth A. Schlenker & SNE & 19 & 2 & 35 & 18 \\
\hline Shannon G. Latchem & SNE & 19 & 2 & 35 & 30 \\
\hline Elisabeth M. Hollmann & SNE & 19 & 2 & 36 & 2 \\
\hline John P. Hollmann & SNE & 19 & 2 & 36 & 22 \\
\hline Kenneth A. Schlenker & SNE & 19 & 2 & 36 & 18 \\
\hline Shannon G. Latchem & SNE & 19 & 2 & 36 & 30 \\
\hline Pamela J. Emery & SNE & 19 & 3 & 7 & 19 \\
\hline Pamela J. Emery & SNE & 19 & 3 & 8 & 19 \\
\hline Pamela J. Emery & SNE & 19 & 3 & 9 & 19 \\
\hline Pamela J. Emery & SNE & 19 & 3 & 10 & 19 \\
\hline Pamela J. Emery & SNE & 19 & 3 & 11 & 19 \\
\hline Pamela J. Emery & SNE & 19 & 3 & 12 & 19 \\
\hline Kenneth A. Schlenker & SNE & 19 & 3 & 13 & 18 \\
\hline Pamela J. Emery & SNE & 19 & 3 & 13 & 19 \\
\hline Kenneth A. Schlenker & SNE & 19 & 3 & 14 & 18 \\
\hline Pamela J. Emery & SNE & 19 & 3 & 14 & 19 \\
\hline Kenneth A. Schlenker & SNE & 19 & 3 & 15 & 18 \\
\hline Pamela J. Emery & SNE & 19 & 3 & 15 & 19 \\
\hline Kenneth A. Schlenker & SNE & 19 & 3 & 16 & 18 \\
\hline Pamela J. Emery & SNE & 19 & 3 & 16 & 19 \\
\hline Pamela J. Emery & SNE & 19 & 3 & 17 & 19 \\
\hline Pamela J. Emery & SNE & 19 & 3 & 18 & 19 \\
\hline Kenneth A. Schlenker & SNE & 19 & 3 & 19 & 18 \\
\hline Pamela J. Emery & SNE & 19 & 3 & 19 & 19 \\
\hline Kenneth A. Schlenker & SNE & 19 & 3 & 20 & 18 \\
\hline Pamela J. Emery & SNE & 19 & 3 & 20 & 19 \\
\hline Kenneth A. Schlenker & SNE & 19 & 3 & 21 & 18 \\
\hline Pamela J. Emery & SNE & 19 & 3 & 21 & 19 \\
\hline Kenneth A. Schlenker & SNE & 19 & 3 & 22 & 18 \\
\hline Pamela J. Emery & SNE & 19 & 3 & 22 & 19 \\
\hline Kenneth A. Schlenker & SNE & 19 & 3 & 23 & 18 \\
\hline Pamela J. Emery & SNE & 19 & 3 & 23 & 19 \\
\hline Pamela J. Emery & SNE & 19 & 3 & 24 & 19 \\
\hline
\end{tabular}


STATE LAND APPLIED FOR UNDER SHALLOW NATURAL GAS LEASING PROGRAM

\section{Applicant}

Pamela J. Emery

Pamela J. Emery

Pamela J. Emery

Pamela J. Emery

Pamela J. Emery

Shannon G. Latchem

Pamela J. Emery

Shannon G. Latchem

Pamela J. Emery

Pamela J. Emery

Dennis R. Carlton

Dennis R. Carlton

Dennis R. Carlton

Dennis R. Carlton

Dennis R. Carlton

Dennis R. Carlton

Dennis R. Carlton

Dennis R. Carlton

Dennis R. Carlton

Dennis R. Carlton

Dennis R. Carlton

Dennis R. Carlton

Dennis R. Carlton

Dennis R. Carlton

Dennis R. Carlton

Dennis R. Carlton

Dennis R. Carlton

Dennis R. Carlton

Franklin A. Birkholt

Franklin A. Birkholt

Franklin A. Birkholt

Franklin A. Birkholt

Franklin A. Birkholt

Franklin A. Birkholt

Franklin A. Birkholt

Franklin A. Birkholt

Franklin A. Birkholt

Franklin A. Birkholt

Franklin A. Birkholt

Franklin A. Birkholt

Franklin A. Birkholt

Franklin A. Birkholt

Franklin A. Birkholt

Franklin A. Birkholt

Franklin A. Birkholt

Franklin A. Birkholt

Raymond R. Latchem

Raymond R. Latchem

Raymond R. Latchem

Raymond R. Latchem

$\begin{array}{ll}\text { M } & \text { T } \\ \text { SNE } & 19 \\ \text { SNE } & 19 \\ \text { SNE } & 19 \\ \text { SNE } & 19 \\ \text { SNE } & 19 \\ \text { SNE } & 19 \\ \text { SNE } & 19 \\ \text { SNE } & 19 \\ \text { SNE } & 19 \\ \text { SNE } & 19 \\ \text { SNE } & 20 \\ \text { SNE } & 20 \\ \text { SNE } & 20 \\ \text { SNE } & 20 \\ \text { SNE } & 20 \\ \text { SNE } & 20 \\ \text { SNE } & 20 \\ \text { SNE } & 20 \\ \text { SNE } & 20 \\ \text { SNE } & 20 \\ \text { SNE } & 20 \\ \text { SNE } & 20 \\ \text { SNE } & 20 \\ \text { SNE } & 20 \\ \text { SNE } & 20 \\ \text { SNE } & 20 \\ \text { SNE } & 20 \\ \text { SNE } & 20\end{array}$

R Section Priority

$\begin{array}{lll}3 & 26 & 19\end{array}$

$27 \quad 19$

$28 \quad 19$

$29 \quad 19$

$30 \quad 19$

$30 \quad 30$

$31 \quad 19$

$31 \quad 30$

$32 \quad 19$

$33 \quad 19$

139

$23 \quad 9$

249

$7 \quad 9$

$8 \quad 9$

$9 \quad 9$

$10 \quad 9$

119

129

149

159

169

$17 \quad 9$

$18 \quad 9$

$19 \quad 9$

$20 \quad 9$

$21 \quad 9$

229

$\begin{array}{lllll}\text { SNW } & 7 & 12 & 1 & 31\end{array}$

$\begin{array}{lllll}\text { SNW } & 7 & 12 & 2 & 31\end{array}$

$\begin{array}{lllll}\text { SNW } & 7 & 12 & 10 & 31\end{array}$

$\begin{array}{lllll}\text { SNW } & 7 & 12 & 11 & 31\end{array}$

$\begin{array}{lllll}\text { SNW } & 7 & 12 & 12 & 31\end{array}$

$\begin{array}{lllll}\text { SNW } & 7 & 12 & 13 & 31\end{array}$

$\begin{array}{lllll}\text { SNW } & 7 & 12 & 14 & 31\end{array}$

$\begin{array}{lllll}\text { SNW } & 7 & 12 & 15 & 31\end{array}$

$\begin{array}{lllll}\text { SNW } & 7 & 12 & 16 & 31\end{array}$

$\begin{array}{lllll}\text { SNW } & 7 & 12 & 21 & 31\end{array}$

$\begin{array}{lllll}\text { SNW } & 7 & 12 & 22 & 31\end{array}$

$\begin{array}{lllll}\text { SNW } & 7 & 12 & 23 & 31\end{array}$

$\begin{array}{lllll}\text { SNW } & 7 & 12 & 24 & 31\end{array}$

$\begin{array}{lllll}\text { SNW } & 7 & 12 & 25 & 31\end{array}$

$\begin{array}{lllll}\text { SNW } & 7 & 12 & 26 & 31\end{array}$

$\begin{array}{lllll}\text { SNW } & 7 & 12 & 27 & 31\end{array}$

$\begin{array}{lllll}\text { SNW } & 7 & 12 & 34 & 31\end{array}$

$\begin{array}{lllll}\text { SNW } & 7 & 12 & 35 & 31\end{array}$

$\begin{array}{lllll}\text { SNW } & 15 & 5 & 1 & 21\end{array}$

$\begin{array}{lllll}\text { SNW } & 15 & 5 & 2 & 21\end{array}$

$\begin{array}{lllll}\text { SNW } & 15 & 5 & 11 & 21\end{array}$

$\begin{array}{lllll}\text { SNW } & 15 & 5 & 12 & 21\end{array}$ 


\section{STATE LAND APPLIED FOR UNDER SHALLOW NATURAL GAS LEASING PROGRAM}

\section{Applicant}

Raymond R. Latchem

Raymond R. Latchem

Raymond R. Latchem

Raymond R. Latchem

Ocean Energy Resources, Inc.

Ocean Energy Resources, Inc.

Ocean Energy Resources, Inc.

Ocean Energy Resources, Inc.

Ocean Energy Resources, Inc.

Ocean Energy Resources, Inc.

Ocean Energy Resources, Inc.

Ocean Energy Resources, Inc.

Ocean Energy Resources, Inc.

Raymond R. Latchem

Ocean Energy Resources, Inc.

Ocean Energy Resources, Inc.

Ocean Energy Resources, Inc.

Ocean Energy Resources, Inc.

Ocean Energy Resources, Inc.

Ocean Energy Resources, Inc.

Ocean Energy Resources, Inc.

Ocean Energy Resources, Inc.

Franklin A. Birkholt

Franklin A. Birkholt

Franklin A. Birkholt

Franklin A. Birkholt

Franklin A. Birkholt

Franklin A. Birkholt

Franklin A. Birkholt

Franklin A. Birkholt

Franklin A. Birkholt

Franklin A. Birkholt

Franklin A. Birkholt

Franklin A. Birkholt

Franklin A. Birkholt

Franklin A. Birkholt

Franklin A. Birkholt

Franklin A. Birkholt

Franklin A. Birkholt

Franklin A. Birkholt

Franklin A. Birkholt

Franklin A. Birkholt

Franklin A. Birkholt

Franklin A. Birkholt

Franklin A. Birkholt

Franklin A. Birkholt

Franklin A. Birkholt

Franklin A. Birkholt

Franklin A. Birkholt

Franklin A. Birkhoit

Franklin A. Birkholt

\begin{tabular}{|c|c|c|c|c|}
\hline M & $T$ & $\mathbf{R}$ & Section & Priority \\
\hline SNW & 15 & 5 & 13 & 21 \\
\hline SNW & 15 & 5 & 14 & 21 \\
\hline SNW & 15 & 5 & 23 & 21 \\
\hline SNW & 15 & 5 & 24 & 21 \\
\hline SNW & 16 & 3 & 4 & 6 \\
\hline SNW & 16 & 3 & 5 & 6 \\
\hline SNW & 16 & 3 & 6 & 6 \\
\hline SNW & 16 & 3 & 7 & 6 \\
\hline SNW & 16 & 3 & 8 & 6 \\
\hline SNW & 16 & 3 & 9 & 6 \\
\hline SNW & 16 & 3 & 16 & 6 \\
\hline SNW & 16 & 3 & 17 & 6 \\
\hline SNW & 16 & 3 & 18 & 6 \\
\hline SNW & 16 & 5 & 35 & 21 \\
\hline SNW & 17 & 1 & 1 & 6 \\
\hline SNW & 17 & 1 & 2 & 6 \\
\hline SNW & 17 & 1 & 8 & 6 \\
\hline SNW & 17 & 1 & 9 & 6 \\
\hline SNW & 17 & 1 & 10 & 6 \\
\hline SNW & 17 & 1 & 11 & 6 \\
\hline SNW & 17 & 1 & 16 & 6 \\
\hline SNW & 17 & 1 & 17 & 6 \\
\hline SNW & 17 & 5 & 4 & 31 \\
\hline SNW & 17 & 5 & 5 & 31 \\
\hline SNW & 17 & 5 & 6 & 31 \\
\hline SNW & 17 & 5 & 7 & 31 \\
\hline SNW & 17 & 5 & 8 & 31 \\
\hline SNW & 17 & 5 & 9 & 31 \\
\hline SNW & 17 & 5 & 16 & 31 \\
\hline SNW & 17 & 5 & 17 & 31 \\
\hline SNW & 17 & 5 & 18 & 31 \\
\hline SNW & 17 & 5 & 19 & 31 \\
\hline SNW & 17 & 5 & 20 & 31 \\
\hline SNW & 17 & 5 & 21 & 31 \\
\hline SNW & 17 & 5 & 28 & 31 \\
\hline SNW & 17 & 5 & 29 & 31 \\
\hline SNW & 17 & 5 & 30 & 31 \\
\hline SNW & 17 & 5 & 31 & 31 \\
\hline SNW & 17 & 5 & 32 & 31 \\
\hline SNW & 17 & 5 & 33 & 31 \\
\hline SNW & 17 & 6 & 1 & 31 \\
\hline SNW & 17 & 6 & 2 & 31 \\
\hline SNW & 17 & 6 & 3 & 31 \\
\hline SNW & 17 & 6 & 10 & 31 \\
\hline SNW & 17 & 6 & 11 & 31 \\
\hline SNW & 17 & 6 & 12 & 31 \\
\hline SNW & 17 & 6 & 13 & 31 \\
\hline SNW & 17 & 6 & 14 & 31 \\
\hline SNW & 17 & 6 & 15 & 31 \\
\hline SNW & 17 & 6 & 22 & 31 \\
\hline SNW & 17 & 6 & 23 & 31 \\
\hline
\end{tabular}




\section{Applicant}

Franklin A. Birkholt

Franklin A. Birkholt

Franklin A. Birkholt

Franklin A. Birkholt

Franklin A. Birkholt

Franklin A. Birkholt

Franklin A. Birkholt

Lowell R. Thomas

Pamela J. Emery

Paul Fromson

Paula J. Mills

Shannon G. Latchem

Lowell R. Thomas

Pamela J. Emery

Paul Fromson

Paula J. Mills

Shannon G. Latchem

Lowell R. Thomas

Pamela J. Emery

Paul Fromson

Paula J. Mills

Shannon G. Latchem

Shannon G. Latchem

Shannon G. Latchem

Shannon G. Latchem

Shannon G. Latchem

Shannon G. Latchem

Shannon G. Latchem

Lowell R. Thomas

Pamela J. Emery

Paul Fromson

Paula J. Mills

Shannon G. Latchem

Lowell R. Thomas

Pamela J. Emery

Paul Fromson

Paula J. Mills

Shannon G. Latchem

Lowell R. Thomas

Pamela J. Emery

Paula J. Mills

Shannon G. Latchem

Lowell R. Thomas

Pamela J. Emery

Paula J. Mills

Shannon G. Latchem

Lowell R. Thomas

Pamela J. Emery

Paula J. Mills

Shannon G. Latchem

Lowell R. Thomas

\section{$\begin{array}{lllll}\text { M } & \text { T } & \text { R } & \text { Section } & \text { Priority }\end{array}$}

$\begin{array}{lllll}\text { SNW } & 17 & 6 & 24 & 31\end{array}$

$\begin{array}{lllll}\text { SNW } & 17 & 6 & 25 & 31\end{array}$

$\begin{array}{lllll}\text { SNW } & 17 & 6 & 26 & 31\end{array}$

$\begin{array}{lllll}\text { SNW } & 17 & 6 & 27 & 31\end{array}$

$\begin{array}{lllll}\text { SNW } & 17 & 6 & 34 & 31\end{array}$

$\begin{array}{lllll}\text { SNW } & 17 & 6 & 35 & 31\end{array}$

$\begin{array}{lllll}\text { SNW } & 17 & 6 & 36 & 31\end{array}$

$\begin{array}{lllll}\text { SNW } & 18 & 1 & 1 & 14\end{array}$

$\begin{array}{lllll}\text { SNW } & 18 & 1 & 1 & 19\end{array}$

$\begin{array}{lllll}\text { SNW } & 18 & 1 & 1 & 34\end{array}$

$\begin{array}{lllll}\text { SNW } & 18 & 1 & 1 & 5\end{array}$

$\begin{array}{lllll}\text { SNW } & 18 & 1 & 1 & 30\end{array}$

$\begin{array}{lllll}\text { SNW } & 18 & 1 & 2 & 14\end{array}$

$\begin{array}{lllll}\text { SNW } & 18 & 1 & 2 & 19\end{array}$

$\begin{array}{lllll}\text { SNW } & 18 & 1 & 2 & 34\end{array}$

$\begin{array}{lllll}\text { SNW } & 18 & 1 & 2 & 5\end{array}$

$\begin{array}{lllll}\text { SNW } & 18 & 1 & 2 & 30\end{array}$

$\begin{array}{lllll}\text { SNW } & 18 & 1 & 3 & 14\end{array}$

$\begin{array}{lllll}\text { SNW } & 18 & 1 & 3 & 19\end{array}$

$\begin{array}{lllll}\text { SNW } & 18 & 1 & 3 & 34\end{array}$

$\begin{array}{lllll}\text { SNW } & 18 & 1 & 3 & 5\end{array}$

$\begin{array}{lllll}\text { SNW } & 18 & 1 & 3 & 30\end{array}$

$\begin{array}{lllll}\text { SNW } & 18 & 1 & 4 & 30\end{array}$

$\begin{array}{lllll}\text { SNW } & 18 & 1 & 5 & 30\end{array}$

$\begin{array}{lllll}\text { SNW } & 18 & 1 & 6 & 30\end{array}$

$\begin{array}{lllll}\text { SNW } & 18 & 1 & 7 & 30\end{array}$

$\begin{array}{lllll}\text { SNW } & 18 & 1 & 8 & 30\end{array}$

$\begin{array}{lllll}\text { SNW } & 18 & 1 & 9 & 30\end{array}$

$\begin{array}{lllll}\text { SNW } & 18 & 1 & 10 & 14\end{array}$

$\begin{array}{lllll}\text { SNW } & 18 & 1 & 10 & 19\end{array}$

$\begin{array}{lllll}\text { SNW } & 18 & 1 & 10 & 34\end{array}$

$\begin{array}{lllll}\text { SNW } & 18 & 1 & 10 & 5\end{array}$

$\begin{array}{lllll}\text { SNW } & 18 & 1 & 10 & 30\end{array}$

$\begin{array}{lllll}\text { SNW } & 18 & 1 & 11 & 14\end{array}$

$\begin{array}{lllll}\text { SNW } & 18 & 1 & 11 & 19\end{array}$

$\begin{array}{lllll}\text { SNW } & 18 & 1 & 11 & 34\end{array}$

$\begin{array}{lllll}\text { SNW } & 18 & 1 & 11 & 5\end{array}$

$\begin{array}{lllll}\text { SNW } & 18 & 1 & 11 & 30\end{array}$

$\begin{array}{lllll}\text { SNW } & 18 & 1 & 12 & 14\end{array}$

$\begin{array}{lllll}\text { SNW } & 18 & 1 & 12 & 19\end{array}$

$\begin{array}{lllll}\text { SNW } & 18 & 1 & 12 & 5\end{array}$

$\begin{array}{lllll}\text { SNW } & 18 & 1 & 12 & 30\end{array}$

$\begin{array}{lllll}\text { SNW } & 18 & 1 & 13 & 14\end{array}$

$\begin{array}{lllll}\text { SNW } & 18 & 1 & 13 & 19\end{array}$

$\begin{array}{lllll}\text { SNW } & 18 & 1 & 13 & 5\end{array}$

$\begin{array}{lllll}\text { SNW } & 18 & 1 & 13 & 30\end{array}$

$\begin{array}{lllll}\text { SNW } & 18 & 1 & 14 & 14\end{array}$

$\begin{array}{lllll}\text { SNW } & 18 & 1 & 14 & 19\end{array}$

$\begin{array}{lllll}\text { SNW } & 18 & 1 & 14 & 5\end{array}$

$\begin{array}{lllll}\text { SNW } & 18 & 1 & 14 & 30\end{array}$

$\begin{array}{llll}\text { SNW } & 18 & 1 & 15\end{array}$

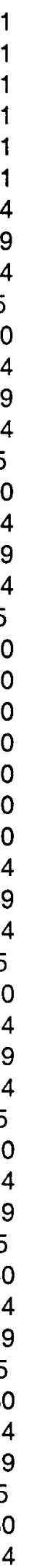




\section{Applicant}

Pamela J. Emery

Paul Fromson

Paula J. Mills

Shannon G. Latchem

Shannon G. Latchem

Shannon G. Latchem

Shannon G. Latchem

Edna A. Latchem

Edna A. Latchem

Edna A. Latchem

Edna A. Latchem

Edna A. Latchem

Edna A. Latchem

Edna A. Latchem

Edna A. Latchem

Edna A. Latchem

Edna A. Latchem

GRI, Inc

Lowell R. Thomas

Paula J. Mills

Edna A. Latchem

GRI, Inc

Lowell R. Thomas

Paula J. Mills

Edna A. Latchem

GRI, Inc

Lowell R. Thomas

Paula J. Mills

GRI, Inc

Lowell R. Thomas

Paula J. Mills

GRI, Inc

Lowell R. Thomas

Paula J. Mills

GRI, Inc

Lowell R. Thomas

Paula J. Mills

GRI, Inc

Lowell R. Thomas

Paula J. Mills

GRI, Inc

Lowell R. Thomas

Paula J. Mills

GRI, Inc

Lowell R. Thomas

Paula J. Mills

Edna A. Latchem

GRI, Inc

Lowell R. Thomas

Paula J. Mills

Edna A. Latchem $\begin{array}{llll}\text { M } & \text { T } & \text { R } & \text { Section Priority }\end{array}$

$\begin{array}{lllll}\text { SNW } & 18 & 1 & 15 & 19\end{array}$

$\begin{array}{lllll}\text { SNW } & 18 & 1 & 15 & 34\end{array}$

$\begin{array}{lllll}\text { SNW } & 18 & 1 & 15 & 5\end{array}$

$\begin{array}{lllll}\text { SNW } & 18 & 1 & 15 & 30\end{array}$

$\begin{array}{lllll}\text { SNW } & 18 & 1 & 16 & 30\end{array}$

$\begin{array}{lllll}\text { SNW } & 18 & 1 & 17 & 30\end{array}$

$\begin{array}{lllll}\text { SNW } & 18 & 1 & 18 & 30\end{array}$

$\begin{array}{lllll}\text { SNW } & 18 & 1 & 19 & 25\end{array}$

$\begin{array}{lllll}\text { SNW } & 18 & 1 & 20 & 25\end{array}$

$\begin{array}{lllll}\text { SNW } & 18 & 1 & 21 & 25\end{array}$

$\begin{array}{lllll}\text { SNW } & 18 & 1 & 28 & 25\end{array}$

$\begin{array}{lllll}\text { SNW } & 18 & 1 & 29 & 25\end{array}$

$\begin{array}{lllll}\text { SNW } & 18 & 1 & 30 & 25\end{array}$

$\begin{array}{lllll}\text { SNW } & 18 & 1 & 31 & 25\end{array}$

$\begin{array}{lllll}\text { SNW } & 18 & 1 & 32 & 25\end{array}$

$\begin{array}{lllll}\text { SNW } & 18 & 1 & 33 & 25\end{array}$

$\begin{array}{lllll}\text { SNW } & 18 & 2 & 1 & 25\end{array}$

$\begin{array}{lllll}\text { SNW } & 18 & 2 & 1 & 23\end{array}$

$\begin{array}{lllll}\text { SNW } & 18 & 2 & 1 & 14\end{array}$

$\begin{array}{lllll}\text { SNW } & 18 & 2 & 1 & 5\end{array}$

$\begin{array}{lllll}\text { SNW } & 18 & 2 & 2 & 25\end{array}$

$\begin{array}{lllll}\text { SNW } & 18 & 2 & 2 & 23\end{array}$

$\begin{array}{lllll}\text { SNW } & 18 & 2 & 2 & 14\end{array}$

$\begin{array}{lllll}\text { SNW } & 18 & 2 & 2 & 5\end{array}$

$\begin{array}{lllll}\text { SNW } & 18 & 2 & 3 & 25\end{array}$

$\begin{array}{lllll}\text { SNW } & 18 & 2 & 3 & 23\end{array}$

$\begin{array}{lllll}\text { SNW } & 18 & 2 & 3 & 14\end{array}$

$\begin{array}{lllll}\text { SNW } & 18 & 2 & 3 & 5\end{array}$

$\begin{array}{lllll}\text { SNW } & 18 & 2 & 4 & 23\end{array}$

$\begin{array}{lllll}\text { SNW } & 18 & 2 & 4 & 14\end{array}$

$\begin{array}{lllll}\text { SNW } & 18 & 2 & 4 & 5\end{array}$

$\begin{array}{lllll}\text { SNW } & 18 & 2 & 5 & 23\end{array}$

$\begin{array}{lllll}\text { SNW } & 18 & 2 & 5 & 14\end{array}$

$\begin{array}{lllll}\text { SNW } & 18 & 2 & 5 & 5\end{array}$

$\begin{array}{lllll}\text { SNW } & 18 & 2 & 6 & 23\end{array}$

$\begin{array}{lllll}\text { SNW } & 18 & 2 & 6 & 14\end{array}$

$\begin{array}{lllll}\text { SNW } & 18 & 2 & 6 & 5\end{array}$

$\begin{array}{lllll}\text { SNW } & 18 & 2 & 7 & 23\end{array}$

$\begin{array}{lllll}\text { SNW } & 18 & 2 & 7 & 14\end{array}$

$\begin{array}{lllll}\text { SNW } & 18 & 2 & 7 & 5\end{array}$

$\begin{array}{lllll}\text { SNW } & 18 & 2 & 8 & 23\end{array}$

$\begin{array}{lllll}\text { SNW } & 18 & 2 & 8 & 14\end{array}$

$\begin{array}{lllll}\text { SNW } & 18 & 2 & 8 & 5\end{array}$

$\begin{array}{lllll}\text { SNW } & 18 & 2 & 9 & 23\end{array}$

$\begin{array}{lllll}\text { SNW } & 18 & 2 & 9 & 14\end{array}$

$\begin{array}{lllll}\text { SNW } & 18 & 2 & 9 & 5\end{array}$

$\begin{array}{lllll}\text { SNW } & 18 & 2 & 10 & 25\end{array}$

$\begin{array}{lllll}\text { SNW } & 18 & 2 & 10 & 23\end{array}$

$\begin{array}{lllll}\text { SNW } & 18 & 2 & 10 & 14\end{array}$

$\begin{array}{lllll}\text { SNW } & 18 & 2 & 10 & 5\end{array}$

$\begin{array}{lllll}\text { SNW } & 18 & 2 & 11 & 25\end{array}$ 


\section{STATE LAND APPLIED FOR UNDER SHALLOW NATURAL GAS LEASING PROGRAM}

\begin{tabular}{|c|c|c|c|c|c|}
\hline Applicant & $\mathbf{M}$ & $\mathbf{T}$ & $\mathbf{R}$ & Section & Priority \\
\hline GRI, Inc & SNW & 18 & 2 & 11 & 23 \\
\hline Lowell R. Thomas & SNW & 18 & 2 & 11 & 14 \\
\hline Paula J. Mills & SNW & 18 & 2 & 11 & 5 \\
\hline Edna A. Latchem & SNW & 18 & 2 & 12 & 25 \\
\hline Lowell R. Thomas & SNW & 18 & 2 & 12 & 14 \\
\hline Paula J. Mills & SNW & 18 & 2 & 12 & 5 \\
\hline Edna A. Latchem & SNW & 18 & 2 & 13 & 25 \\
\hline Lowell R. Thomas & SNW & 18 & 2 & 13 & 14 \\
\hline Paula J. Mills & SNW & 18 & 2 & 13 & 5 \\
\hline Edna A. Latchem & SNW & 18 & 2 & 14 & 25 \\
\hline Lowell R. Thomas & SNW & 18 & 2 & 14 & 14 \\
\hline Paula J. Mills & SNW & 18 & 2 & 14 & 5 \\
\hline Edna A. Latchem & SNW & 18 & 2 & 15 & 25 \\
\hline Lowell R. Thomas & SNW & 18 & 2 & 15 & 14 \\
\hline Paula J. Mills & SNW & 18 & 2 & 15 & 5 \\
\hline GRI, Inc & SNW & 18 & 2 & 16 & 23 \\
\hline Lowell R. Thomas & SNW & 18 & 2 & 16 & 14 \\
\hline Paula J. Mills & SNW & 18 & 2 & 16 & 5 \\
\hline GRI, Inc & SNW & 18 & 2 & 17 & 23 \\
\hline Lowell R. Thomas & SNW & 18 & 2 & 17 & 14 \\
\hline Paula J. Mills & SNW & 18 & 2 & 17 & 5 \\
\hline GRI, Inc & SNW & 18 & 2 & 18 & 23 \\
\hline Lowell R. Thomas & SNW & 18 & 2 & 18 & 14 \\
\hline Paula J. Mills & SNW & 18 & 2 & 18 & 5 \\
\hline GRI, Inc & SNW & 18 & 3 & 1 & 23 \\
\hline GRI, Inc & SNW & 18 & 3 & 2 & 23 \\
\hline GRI, Inc & SNW & 18 & 3 & 3 & 23 \\
\hline Evergreen Resources, Inc. & SNW & 18 & 3 & 4 & 11 \\
\hline Mark S. Sexton & SNW & 18 & 3 & 4 & 24 \\
\hline Evergreen Resources, Inc. & SNW & 18 & 3 & 5 & 11 \\
\hline Mark S. Sexton & SNW & 18 & 3 & 5 & 24 \\
\hline Evergreen Resources, Inc. & SNW & 18 & 3 & 6 & 11 \\
\hline Mark S. Sexton & SNW & 18 & 3 & 6 & 24 \\
\hline Evergreen Resources, Inc. & SNW & 18 & 3 & 7 & 11 \\
\hline Mark S. Sexton & SNW & 18 & 3 & 7 & 24 \\
\hline Evergreen Resources, Inc. & SNW & 18 & 3 & 8 & 11 \\
\hline Mark S. Sexton & SNW & 18 & 3 & 8 & 24 \\
\hline Evergreen Resources, Inc. & SNW & 18 & 3 & 9 & 11 \\
\hline Mark S. Sexton & SNW & 18 & 3 & 9 & 24 \\
\hline GRI, Inc & SNW & 18 & 3 & 10 & 23 \\
\hline Lowell R. Thomas & SNW & 18 & 3 & 10 & 14 \\
\hline Paula J. Mills & SNW & 18 & 3 & 10 & 5 \\
\hline GRI, Inc & SNW & 18 & 3 & 11 & 23 \\
\hline Lowell R. Thomas & SNW & 18 & 3 & 11 & 14 \\
\hline Paula J. Mills & SNW & 18 & 3 & 11 & 5 \\
\hline GRI, Inc & SNW & 18 & 3 & 12 & 23 \\
\hline GRI, Inc & SNW & 18 & 3 & 13 & 23 \\
\hline Lowell R. Thomas & SNW & 18 & 3 & 13 & 14 \\
\hline Paula J. Mills & SNW & 18 & 3 & 13 & 5 \\
\hline GRI, Inc & SNW & 18 & 3 & 14 & 23 \\
\hline Lowell R. Thomas & SNW & 18 & 3 & 14 & 14 \\
\hline
\end{tabular}




\section{STATE LAND APPLIED FOR UNDER SHALLOW NATURAL GAS LEASING PROGRAM}

\begin{tabular}{|c|c|c|c|c|c|}
\hline Applicant & $\mathbf{M}$ & $\mathbf{T}$ & $\mathbf{R}$ & Section & Priority \\
\hline Paula J. Mills & SNW & 18 & 3 & 14 & 5 \\
\hline GRI, Inc & SNW & 18 & 3 & 15 & 23 \\
\hline Lowell R. Thomas & SNW & 18 & 3 & 15 & 14 \\
\hline Paula J. Mills & SNW & 18 & 3 & 15 & 5 \\
\hline Evergreen Resources, Inc. & SNW & 18 & 3 & 16 & 11 \\
\hline Mark S. Sexton & SNW & 18 & 3 & 16 & 24 \\
\hline Evergreen Resources, Inc. & SNW & 18 & 3 & 17 & 11 \\
\hline Mark S. Sexton & SNW & 18 & 3 & 17 & 24 \\
\hline Evergreen Resources, Inc. & SNW & 18 & 3 & 18 & 11 \\
\hline Mark S. Sexton & SNW & 18 & 3 & 18 & 24 \\
\hline GRI, Inc & SNW & 18 & 3 & 22 & 23 \\
\hline Lowell R. Thomas & SNW & 18 & 3 & 22 & 14 \\
\hline Ocean Energy Resources, Inc. & SNW & 18 & 3 & 22 & 6 \\
\hline Paula J. Mills & SNW & 18 & 3 & 22 & 5 \\
\hline GRI, Inc & SNW & 18 & 3 & 23 & 23 \\
\hline Lowell R. Thomas & SNW & 18 & 3 & 23 & 14 \\
\hline Ocean Energy Resources, Inc. & SNW & 18 & 3 & 23 & 6 \\
\hline Paula J. Mills & SNW & 18 & 3 & 23 & 5 \\
\hline GRI, Inc & SNW & 18 & 3 & 24 & 23 \\
\hline Lowell R. Thomas & SNW & 18 & 3 & 24 & 14 \\
\hline Ocean Energy Resources, Inc. & SNW & 18 & 3 & 24 & 6 \\
\hline Paula J. Mills & SNW & 18 & 3 & 24 & 5 \\
\hline GRI, Inc & SNW & 18 & 3 & 27 & 23 \\
\hline Lowell R. Thomas & SNW & 18 & 3 & 27 & 14 \\
\hline Ocean Energy Resources, Inc. & SNW & 18 & 3 & 27 & 6 \\
\hline Paula J. Mills & SNW & 18 & 3 & 27 & 5 \\
\hline Franklin A. Birkholt & SNW & 18 & 4 & 1 & 31 \\
\hline GRI, Inc & SNW & 18 & 4 & 1 & 23 \\
\hline Lowell R. Thomas & SNW & 18 & 4 & 1 & 14 \\
\hline Paula J. Mills & SNW & 18 & 4 & 1 & 5 \\
\hline Franklin A. Birkholt & SNW & 18 & 4 & 2 & 31 \\
\hline GRI, Inc & SNW & 18 & 4 & 2 & 23 \\
\hline Lowell R. Thomas & SNW & 18 & 4 & 2 & 14 \\
\hline Paula J. Mills & SNW & 18 & 4 & 2 & 5 \\
\hline Franklin A. Birkholt & SNW & 18 & 4 & 3 & 31 \\
\hline GRI, Inc & SNW & 18 & 4 & 3 & 23 \\
\hline Lowell R. Thomas & SNW & 18 & 4 & 3 & 14 \\
\hline Paula J. Mills & SNW & 18 & 4 & 3 & 5 \\
\hline Franklin A. Birkholt & SNW & 18 & 4 & 10 & 31 \\
\hline GRI, Inc & SNW & 18 & 4 & 10 & 23 \\
\hline Lowell R. Thomas & SNW & 18 & 4 & 10 & 14 \\
\hline Paula J. Mills & SNW & 18 & 4 & 10 & 5 \\
\hline Franklin A. Birkholt & SNW & 18 & 4 & 11 & 31 \\
\hline GRI, Inc & SNW & 18 & 4 & 11 & 23 \\
\hline Lowell R. Thomas & SNW & 18 & 4 & 11 & 14 \\
\hline Paula J. Mills & SNW & 18 & 4 & 11 & 5 \\
\hline Franklin A. Birkholt & SNW & 18 & 4 & 12 & 31 \\
\hline GRI, Inc & SNW & 18 & 4 & 12 & 23 \\
\hline Lowell R. Thomas & SNW & 18 & 4 & 12 & 14 \\
\hline Paula J. Mills & SNW & 18 & 4 & 12 & 5 \\
\hline Franklin A. Birkholt & SNW & 18 & 4 & 13 & 31 \\
\hline
\end{tabular}




\section{STATE LAND APPLIED FOR UNDER SHALLOW NATURAL GAS LEASING PROGRAM}

Applicant

GRI, Inc

Lowell R. Thomas

Paula J. Mills

Franklin A. Birkholt

GRI, Inc

Lowell R. Thomas

Paula J. Mills

Franklin A. Birkholt

GRI, Inc

Lowell R. Thomas

Paula J. Mills

Franklin A. Birkholt

GRI, Inc

Lowell R. Thomas

Ocean Energy Resources, Inc.

Paula J. Mills

Franklin A. Birkholt

GRI, Inc

Lowell R. Thomas

Ocean Energy Resources, Inc.

Paula J. Mills

Franklin A. Birkholt

GRI, Inc

Lowell R. Thomas

Ocean Energy Resources, Inc.

Paula J. Mills

Franklin A. Birkholt

GRI, Inc

Lowell R. Thomas

Ocean Energy Resources, Inc.

Paula J. Mills

Franklin A. Birkholt

GRI, Inc

Lowell R. Thomas

Ocean Energy Resources, Inc.

Paula J. Mills

Franklin A. Birkholt

GRI, Inc

Lowell R. Thomas

Ocean Energy Resources, Inc.

Paula J. Mills

Franklin A. Birkholt

GRI, Inc

Lowell R. Thomas

Ocean Energy Resources, Inc.

Paula J. Mills

Franklin A. Birkholt

GRI, Inc

Lowell R. Thomas

Ocean Energy Resources, Inc.

Paula J. Mills

\begin{tabular}{|c|c|c|c|c|}
\hline $\mathbf{M}$ & $\mathbf{T}$ & $\mathbf{R}$ & Section & Priority \\
\hline SNW & 18 & 4 & 13 & 23 \\
\hline SNW & 18 & 4 & 13 & 14 \\
\hline SNW & 18 & 4 & 13 & 5 \\
\hline SNW & 18 & 4 & 14 & 31 \\
\hline SNW & 18 & 4 & 14 & 23 \\
\hline SNW & 18 & 4 & 14 & 14 \\
\hline SNW & 18 & 4 & 14 & 5 \\
\hline SNW & 18 & 4 & 15 & 31 \\
\hline SNW & 18 & 4 & 15 & 23 \\
\hline SNW & 18 & 4 & 15 & 14 \\
\hline SNW & 18 & 4 & 15 & 5 \\
\hline SNW & 18 & 4 & 22 & 31 \\
\hline SNW & 18 & 4 & 22 & 23 \\
\hline SNW & 18 & 4 & 22 & 14 \\
\hline SNW & 18 & 4 & 22 & 6 \\
\hline SNW & 18 & 4 & 22 & 5 \\
\hline SNW & 18 & 4 & 23 & 31 \\
\hline SNW & 18 & 4 & 23 & 23 \\
\hline SNW & 18 & 4 & 23 & 14 \\
\hline SNW & 18 & 4 & 23 & 6 \\
\hline SNW & 18 & 4 & 23 & 5 \\
\hline SNW & 18 & 4 & 24 & 31 \\
\hline SNW & 18 & 4 & 24 & 23 \\
\hline SNW & 18 & 4 & 24 & 14 \\
\hline SNW & 18 & 4 & 24 & 6 \\
\hline SNW & 18 & 4 & 24 & 5 \\
\hline SNW & 18 & 4 & 25 & 31 \\
\hline SNW & 18 & 4 & 25 & 23 \\
\hline SNW & 18 & 4 & 25 & 14 \\
\hline SNW & 18 & 4 & 25 & 6 \\
\hline SNW & 18 & 4 & 25 & 5 \\
\hline SNW & 18 & 4 & 26 & 31 \\
\hline SNW & 18 & 4 & 26 & 23 \\
\hline SNW & 18 & 4 & 26 & 14 \\
\hline SNW & 18 & 4 & 26 & 6 \\
\hline SNW & 18 & 4 & 26 & 5 \\
\hline SNW & 18 & 4 & 27 & 31 \\
\hline SNW & 18 & 4 & 27 & 23 \\
\hline SNW & 18 & 4 & 27 & 14 \\
\hline SNW & 18 & 4 & 27 & 6 \\
\hline SNW & 18 & 4 & 27 & 5 \\
\hline SNW & 18 & 4 & 34 & 31 \\
\hline SNW & 18 & 4 & 34 & 23 \\
\hline SNW & 18 & 4 & 34 & 14 \\
\hline SNW & 18 & 4 & 34 & 6 \\
\hline SNW & 18 & 4 & 34 & 5 \\
\hline SNW & 18 & 4 & 35 & 31 \\
\hline SNW & 18 & 4 & 35 & 23 \\
\hline SNW & 18 & 4 & 35 & 14 \\
\hline SNW & 18 & 4 & 35 & 6 \\
\hline SNW & 18 & 4 & 35 & 5 \\
\hline
\end{tabular}




\section{STATE LAND APPLIED FOR UNDER SHALLOW NATURAL GAS LEASING PROGRAM}

\section{Applicant}

Franklin A. Birkholt

GRI, Inc

Lowell R. Thomas

Ocean Energy Resources, Inc.

Paula J. Mills

Dennis R. Carlton

Dennis R. Carlton

Dennis R. Carlton

Dennis R. Carlton

Dennis R. Carlton

Dennis R. Carlton

Dennis R. Carlton

Dennis R. Carlton

Dennis R. Carlton

Dennis R. Carlton

Dennis R. Carlton

Dennis R. Carlton

Dennis R. Carlton

Dennis R. Carlton

Dennis R. Carlton

Dennis R. Carlton

Dennis R. Carlton

Dennis R. Carlton

Dennis R. Carlton

Dennis R. Carlton

Dennis R. Carlton

Dennis R. Carlton

Dennis R. Carlton

Dennis R. Carlton

Dennis R. Carlton

Dennis R. Carlton

Dennis R. Carlton

Dennis R. Carlton

Dennis R. Carlton

Dennis R. Carlton

Dennis R. Carlton

Dennis R. Carlton

Dennis R. Carlton

Dennis R. Carlton

Dennis R. Carlton

Dennis R. Carlton

Lowell R. Thomas

Pamela J. Emery

Paula J. Mills

Growth Resources, Ltd

Lowell R. Thomas

Pamela J. Emery

Paula J. Mills

Growth Resources, Ltd

Lowell R. Thomas

Pamela J. Emery
M T R Section Priority

$\begin{array}{ll}\text { SNW } & 18 \\ \text { SNW } & 18 \\ \text { SNW } & 18\end{array}$

SNW 18

SNW 18

SNW 18

SNW 18

SNW 18

SNW 18

SNW 18

SNW 18

SNW 18

SNW 18

SNW 18

SNW 18

SNW 18

SNW 18

SNW 18

SNW 18

SNW 18

SNW 18

SNW 18

SNW 18

SNW 18

SNW 18

SNW 18

SNW 18

SNW 18

SNW 18

SNW 18

SNW 18

SNW 18

SNW 18

SNW 18

SNW 18

SNW 18

SNW 18

SNW 18

SNW 18

SNW 18

SNW 18

SNW 19

SNW 19

SNW 19

SNW 19

SNW 19

SNW 19

SNW 19

SNW 19

SNW 19

SNW 19
$36 \quad 31$

$36 \quad 23$

$36 \quad 14$

$36 \quad 6$

$36 \quad 5$

39

49

$5 \quad 9$

69

$7 \quad 9$

89

$9 \quad 9$

$10 \quad 9$

$16 \quad 9$

179

189

$19 \quad 9$

209

$27 \quad 9$

$28 \quad 9$

$29 \quad 9$

$30 \quad 9$

$32 \quad 9$

$33 \quad 9$

$34 \quad 9$

19

119

129

$13 \quad 9$

149

159

229

$23 \quad 9$

249

$25 \quad 9$

269

$27 \quad 9$

$34 \quad 9$

$35 \quad 9$

$36 \quad 9$

$34 \quad 14$

$34 \quad 19$

$34 \quad 5$

$35 \quad 13$

$35 \quad 14$

$35 \quad 19$

$36 \quad 19$
$31 \quad 9$

$35 \quad 5$

$36 \quad 13$

$36 \quad 14$ 


\section{STATE LAND APPLIED FOR UNDER}

\section{SHALLOW NATURAL GAS LEASING PROGRAM}

\section{Applicant}

Paula J. Mills

Kenneth A. Schlenker

Kenneth A. Schlenker

Kenneth A. Schlenker

Kenneth A. Schlenker

Kenneth A. Schlenker

Kenneth A. Schlenker

Kenneth A. Schlenker

Kenneth A. Schlenker

Kenneth A. Schlenker

Kenneth A. Schlenker

Kenneth A. Schlenker

Kenneth A. Schlenker

Kenneth A. Schlenker

Kenneth A. Schlenker

Kenneth A. Schlenker

Kenneth A. Schlenker

Kenneth A. Schlenker

Kenneth A. Schlenker

Kenneth A. Schlenker

Kenneth A. Schlenker

Kenneth A. Schlenker

Kenneth A. Schlenker

Nancy A. Hollmann

Ronald D. Hollmann

Kenneth A. Schlenker

Nancy A. Holimann

Ronald D. Hollmann

Kenneth A. Schlenker

Nancy A. Hollmann

Ronald D. Hollmann

Kenneth A. Schlenker

Nancy A. Hollmann

Ronald D. Hollmann

Kenneth A. Schlenker

Nancy A. Hollmann

Ronald D. Hollmann

Kenneth A. Schlenker

Nancy A. Hollmann

Ronald D. Hollmann

Kenneth A. Schlenker

Kenneth A. Schlenker

Kenneth A. Schlenker

Kenneth A. Schlenker

Kenneth A. Schlenker

Kenneth A. Schlenker

Nancy A. Hollmann

Ronald D. Hollmann

Kenneth A. Schlenker

Nancy A. Hollmann

Ronald D. Hollmann

\begin{tabular}{|c|c|c|c|c|}
\hline $\mathbf{M}$ & $T$ & $\mathbf{R}$ & Section & Priority \\
\hline SNW & 19 & 1 & 36 & 5 \\
\hline SNW & 19 & 2 & 4 & 18 \\
\hline SNW & 19 & 2 & 5 & 18 \\
\hline SNW & 19 & 2 & 6 & 18 \\
\hline SNW & 19 & 2 & 7 & 18 \\
\hline SNW & 19 & 2 & 8 & 18 \\
\hline SNW & 19 & 2 & 9 & 18 \\
\hline SNW & 19 & 2 & 16 & 18 \\
\hline SNW & 19 & 2 & 17 & 18 \\
\hline SNW & 19 & 2 & 18 & 18 \\
\hline SNW & 19 & 2 & 19 & 18 \\
\hline SNW & 19 & 2 & 20 & 18 \\
\hline SNW & 19 & 2 & 21 & 18 \\
\hline SNW & 19 & 2 & 28 & 18 \\
\hline SNW & 19 & 2 & 29 & 18 \\
\hline SNW & 19 & 2 & 30 & 18 \\
\hline SNW & 19 & 2 & 31 & 18 \\
\hline SNW & 19 & 2 & 32 & 18 \\
\hline SNW & 19 & 2 & 33 & 18 \\
\hline SNW & 19 & 3 & 1 & 18 \\
\hline SNW & 19 & 3 & 2 & 18 \\
\hline SNW & 19 & 3 & 3 & 18 \\
\hline SNW & 19 & 3 & 4 & 18 \\
\hline SNW & 19 & 3 & 4 & 1 \\
\hline SNW & 19 & 3 & 4 & 20 \\
\hline SNW & 19 & 3 & 5 & 18 \\
\hline SNW & 19 & 3 & 5 & 1 \\
\hline SNW & 19 & 3 & 5 & 20 \\
\hline SNW & 19 & 3 & 6 & 18 \\
\hline SNW & 19 & 3 & 6 & 1 \\
\hline SNW & 19 & 3 & 6 & 20 \\
\hline SNW & 19 & 3 & 7 & 18 \\
\hline SNW & 19 & 3 & 7 & 1 \\
\hline SNW & 19 & 3 & 7 & 20 \\
\hline SNW & 19 & 3 & 8 & 18 \\
\hline SNW & 19 & 3 & 8 & 1 \\
\hline SNW & 19 & 3 & 8 & 20 \\
\hline SNW & 19 & 3 & 9 & 18 \\
\hline SNW & 19 & 3 & 9 & 1 \\
\hline SNW & 19 & 3 & 9 & 20 \\
\hline SNW & 19 & 3 & 10 & 18 \\
\hline SNW & 19 & 3 & 11 & 18 \\
\hline SNW & 19 & 3 & 12 & 18 \\
\hline SNW & 19 & 3 & 13 & 18 \\
\hline SNW & 19 & 3 & 15 & 18 \\
\hline SNW & 19 & 3 & 16 & 18 \\
\hline SNW & 19 & 3 & 16 & 1 \\
\hline SNW & 19 & 3 & 16 & 20 \\
\hline SNW & 19 & 3 & 17 & 18 \\
\hline SNW & 19 & 3 & 17 & 1 \\
\hline SNW & 19 & 3 & 17 & 20 \\
\hline
\end{tabular}




\section{Applicant}

Kenneth A. Schlenker

Nancy A. Hollmann

Ronald D. Hollmann

Kenneth A. Schlenker

Nancy A. Hollmann

Ronald D. Hollmann

Kenneth A. Schlenker

Nancy A. Hollmann

Ronald D. Hollmann

Kenneth A. Schlenker

Nancy A. Hollmann

Ronald D. Hollmann

Kenneth A. Schlenker

Kenneth A. Schlenker

Kenneth A. Schlenker

Kenneth A. Schlenker

Kenneth A. Schlenker

Kenneth A. Schlenker

Kenneth A. Schlenker

Nancy A. Hollmann

Ronald D. Hollmann

Nancy A. Hollmann

Ronald D. Hollmann

Ted $\mathrm{H}$. Williams

Nancy A. Hollmann

Ronald D. Hollmann

Ted $\mathrm{H}$. Williams

Nancy A. Hollmann

Ronald D. Hollmann

Ted $\mathrm{H}$. Williams

Nancy A. Hollmann

Ronald D. Hollmann

Ted $\mathrm{H}$. Williams

Nancy A. Hollmann

Ronald D. Hollmann

Ted $\mathrm{H}$. Williams

Ted $\mathrm{H}$. Williams

Ted $\mathrm{H}$. Williams

Ted $\mathrm{H}$. Williams

Nancy A. Hollmann

Ronald D. Hollmann

Ted $\mathrm{H}$. Williams

Nancy A. Hollmann

Ronald D. Hollmann

Ted $\mathrm{H}$. Williams

Nancy A. Hollmann

Ronald D. Hollmann

Ted H. Williams

Nancy A. Hollmann

Ronald D. Hollmann

Nancy A. Hollmann

\begin{tabular}{|c|c|c|c|c|}
\hline $\mathbf{M}$ & $\mathbf{T}$ & $\mathbf{R}$ & Section & Priority \\
\hline SNW & 19 & 3 & 18 & 18 \\
\hline SNW & 19 & 3 & 18 & 1 \\
\hline SNW & 19 & 3 & 18 & 20 \\
\hline SNW & 19 & 3 & 19 & 18 \\
\hline SNW & 19 & 3 & 19 & 1 \\
\hline SNW & 19 & 3 & 19 & 20 \\
\hline SNW & 19 & 3 & 20 & 18 \\
\hline SNW & 19 & 3 & 20 & 1 \\
\hline SNW & 19 & 3 & 20 & 20 \\
\hline SNW & 19 & 3 & 21 & 18 \\
\hline SNW & 19 & 3 & 21 & 1 \\
\hline SNW & 19 & 3 & 21 & 20 \\
\hline SNW & 19 & 3 & 22 & 18 \\
\hline SNW & 19 & 3 & 23 & 18 \\
\hline SNW & 19 & 3 & 24 & 18 \\
\hline SNW & 19 & 3 & 25 & 18 \\
\hline SNW & 19 & 3 & 26 & 18 \\
\hline SNW & 19 & 3 & 27 & 18 \\
\hline SNW & 19 & 3 & 28 & 18 \\
\hline SNW & 19 & 3 & 28 & 1 \\
\hline SNW & 19 & 3 & 28 & 20 \\
\hline SNW & 19 & 3 & 29 & 1 \\
\hline SNW & 19 & 3 & 29 & 20 \\
\hline SNW & 19 & 3 & 29 & 27 \\
\hline SNW & 19 & 3 & 30 & 1 \\
\hline SNW & 19 & 3 & 30 & 20 \\
\hline SNW & 19 & 3 & 30 & 27 \\
\hline SNW & 19 & 3 & 31 & 1 \\
\hline SNW & 19 & 3 & 31 & 20 \\
\hline SNW & 19 & 3 & 31 & 27 \\
\hline SNW & 19 & 3 & 32 & 1 \\
\hline SNW & 19 & 3 & 32 & 20 \\
\hline SNW & 19 & 3 & 32 & 27 \\
\hline SNW & 19 & 3 & 33 & 1 \\
\hline SNW & 19 & 3 & 33 & 20 \\
\hline SNW & 19 & 3 & 33 & 27 \\
\hline SNW & 19 & 3 & 34 & 27 \\
\hline SNW & 19 & 3 & 35 & 27 \\
\hline SNW & 19 & 3 & 36 & 27 \\
\hline SNW & 19 & 4 & 1 & 1 \\
\hline SNW & 19 & 4 & 1 & 20 \\
\hline SNW & 19 & 4 & 1 & 27 \\
\hline SNW & 19 & 4 & 2 & 1 \\
\hline SNW & 19 & 4 & 2 & 20 \\
\hline SNW & 19 & 4 & 2 & 27 \\
\hline SNW & 19 & 4 & 3 & 1 \\
\hline SNW & 19 & 4 & 3 & 20 \\
\hline SNW & 19 & 4 & 3 & 27 \\
\hline SNW & 19 & 4 & 4 & 1 \\
\hline SNW & 19 & 4 & 4 & 20 \\
\hline SNW & 19 & 4 & 7 & 1 \\
\hline
\end{tabular}


STATE LAND APPLIED FOR UNDER SHALLOW NATURAL GAS LEASING PROGRAM

\section{Applicant}

Ronald D. Hollmann

Nancy A. Hollmann

Ronald D. Hollmann

Nancy A. Hollmann

Ronald D. Hollmann

Ted $\mathrm{H}$. Williams

Nancy A. Hollmann

Ronald D. Hollmann

Ted H. Williams

Nancy A. Hollmann

Ronald D. Hollmann

Ted $\mathrm{H}$. Williams

Nancy A. Hollmann

Ronald D. Hollmann

Ted H. Williams

Nancy A. Hollmann

Ronald D. Hollmann

Ted $\mathrm{H}$. Williams

Nancy A. Hollmann

Ronald D. Hollmann

Ted $\mathrm{H}$. Williams

Nancy A. Hollmann

Ronald D. Hollmann

Ted $\mathrm{H}$. Williams

Nancy A. Hollmann

Ronald D. Hollmann

Ted H. Williams

Nancy A. Hollmann

Ronald D. Hollmann

Ted $\mathrm{H}$. Williams

Nancy A. Hollmann

Ronald D. Hollmann

Nancy A. Hollmann

Ronald D. Hollmann

Ted $\mathrm{H}$. Williams

Nancy A. Hollmann

Ronald D. Hollmann

Ted H. Williams

Nancy A. Hollmann

Ronald D. Hollmann

Ted $\mathrm{H}$. Williams

Nancy A. Hollmann

Ronald D. Hollmann

Ted $\mathrm{H}$. Williams

Nancy A. Hollmann

Ronald D. Hollmann

Ted $\mathrm{H}$. Williams

Nancy A. Hollmann

Ronald D. Hollmann

Ted $\mathrm{H}$. Williams

Nancy A. Hollmann

\begin{tabular}{|c|c|c|c|c|}
\hline $\mathbf{M}$ & $\mathbf{T}$ & $\mathbf{R}$ & Section & Priority \\
\hline SNW & 19 & 4 & 7 & 20 \\
\hline SNW & 19 & 4 & 8 & 1 \\
\hline SNW & 19 & 4 & 8 & 20 \\
\hline SNW & 19 & 4 & 9 & 1 \\
\hline SNW & 19 & 4 & 9 & 20 \\
\hline SNW & 19 & 4 & 9 & 27 \\
\hline SNW & 19 & 4 & 10 & 1 \\
\hline SNW & 19 & 4 & 10 & 20 \\
\hline SNW & 19 & 4 & 10 & 27 \\
\hline SNW & 19 & 4 & 11 & 1 \\
\hline SNW & 19 & 4 & 11 & 20 \\
\hline SNW & 19 & 4 & 11 & 27 \\
\hline SNW & 19 & 4 & 12 & 1 \\
\hline SNW & 19 & 4 & 12 & 20 \\
\hline SNW & 19 & 4 & 12 & 27 \\
\hline SNW & 19 & 4 & 13 & 1 \\
\hline SNW & 19 & 4 & 13 & 20 \\
\hline SNW & 19 & 4 & 13 & 27 \\
\hline SNW & 19 & 4 & 14 & 1 \\
\hline SNW & 19 & 4 & 14 & 20 \\
\hline SNW & 19 & 4 & 14 & 27 \\
\hline SNW & 19 & 4 & 15 & 1 \\
\hline SNW & 19 & 4 & 15 & 20 \\
\hline SNW & 19 & 4 & 15 & 27 \\
\hline SNW & 19 & 4 & 16 & 1 \\
\hline SNW & 19 & 4 & 16 & 20 \\
\hline SNW & 19 & 4 & 16 & 27 \\
\hline SNW & 19 & 4 & 17 & 1 \\
\hline SNW & 19 & 4 & 17 & 20 \\
\hline SNW & 19 & 4 & 17 & 27 \\
\hline SNW & 19 & 4 & 18 & 1 \\
\hline SNW & 19 & 4 & 18 & 20 \\
\hline SNW & 19 & 4 & 19 & 1 \\
\hline SNW & 19 & 4 & 19 & 20 \\
\hline SNW & 19 & 4 & 19 & 27 \\
\hline SNW & 19 & 4 & 20 & 1 \\
\hline SNW & 19 & 4 & 20 & 20 \\
\hline SNW & 19 & 4 & 20 & 27 \\
\hline SNW & 19 & 4 & 21 & 1 \\
\hline SNW & 19 & 4 & 21 & 20 \\
\hline SNW & 19 & 4 & 21 & 27 \\
\hline SNW & 19 & 4 & 22 & 1 \\
\hline SNW & 19 & 4 & 22 & 20 \\
\hline SNW & 19 & 4 & 22 & 27 \\
\hline SNW & 19 & 4 & 23 & 1 \\
\hline SNW & 19 & 4 & 23 & 20 \\
\hline SNW & 19 & 4 & 23 & 27 \\
\hline SNW & 19 & 4 & 24 & 1 \\
\hline SNW & 19 & 4 & 24 & 20 \\
\hline SNW & 19 & 4 & 24 & 27 \\
\hline SNW & 19 & 4 & 25 & 1 \\
\hline
\end{tabular}


STATE LAND APPLIED FOR UNDER SHALLOW NATURAL GAS LEASING PROGRAM

\begin{tabular}{|c|c|c|c|c|c|}
\hline Applicant & $\mathbf{M}$ & $\mathbf{T}$ & $\mathbf{R}$ & Section & Priority \\
\hline Ronald D. Hollmann & SNW & 19 & 4 & 25 & 20 \\
\hline Ted H. Williams & SNW & 19 & 4 & 25 & 27 \\
\hline Nancy A. Hollmann & SNW & 19 & 4 & 26 & 1 \\
\hline Ronald D. Hollmann & SNW & 19 & 4 & 26 & 20 \\
\hline Ted H. Williams & SNW & 19 & 4 & 26 & 27 \\
\hline Nancy A. Hollmann & SNW & 19 & 4 & 27 & 1 \\
\hline Ronald D. Hollmann & SNW & 19 & 4 & 27 & 20 \\
\hline Ted H. Williams & SNW & 19 & 4 & 27 & 27 \\
\hline Nancy A. Hollmann & SNW & 19 & 4 & 28 & 1 \\
\hline Ronald D. Hollmann & SNW & 19 & 4 & 28 & 20 \\
\hline Nancy A. Hollmann & SNW & 19 & 4 & 29 & 1 \\
\hline Ronald D. Hollmann & SNW & 19 & 4 & 29 & 20 \\
\hline Nancy A. Hollmann & SNW & 19 & 4 & 30 & 1 \\
\hline Ronald D. Hollmann & SNW & 19 & 4 & 30 & 20 \\
\hline Nancy A. Hollmann & SNW & 19 & 4 & 31 & 1 \\
\hline Ronald D. Hollmann & SNW & 19 & 4 & 31 & 20 \\
\hline Nancy A. Hollmann & SNW & 19 & 4 & 32 & 1 \\
\hline Ronald D. Hollmann & SNW & 19 & 4 & 32 & 20 \\
\hline Nancy A. Hollmann & SNW & 19 & 4 & 33 & 1 \\
\hline Ronald D. Hollmann & SNW & 19 & 4 & 33 & 20 \\
\hline Nancy A. Hollmann & SNW & 19 & 4 & 34 & 1 \\
\hline Ronald D. Hollmann & SNW & 19 & 4 & 34 & 20 \\
\hline Ted H. Williams & SNW & 19 & 4 & 34 & 27 \\
\hline Nancy A. Hollmann & SNW & 19 & 4 & 35 & 1 \\
\hline Ronald D. Hollmann & SNW & 19 & 4 & 35 & 20 \\
\hline Ted H. Williams & SNW & 19 & 4 & 35 & 27 \\
\hline Nancy A. Hollmann & SNW & 19 & 4 & 36 & 1 \\
\hline Ronald D. Hoilmann & SNW & 19 & 4 & 36 & 20 \\
\hline Ted H. Williams & SNW & 19 & 4 & 36 & 27 \\
\hline Nancy A. Hollmann & SNW & 19 & 5 & 10 & 1 \\
\hline Ronald D. Hollmann & SNW & 19 & 5 & 10 & 20 \\
\hline Nancy A. Hollmann & SNW & 19 & 5 & 11 & 1 \\
\hline Ronald D. Hollmann & SNW & 19 & 5 & 11 & 20 \\
\hline Nancy A. Hollmann & SNW & 19 & 5 & 12 & 1 \\
\hline Ronald D. Hollmann & SNW & 19 & 5 & 12 & 20 \\
\hline Nancy A. Hollmann & SNW & 19 & 5 & 13 & 1 \\
\hline Ronald D. Hollmann & SNW & 19 & 5 & 13 & 20 \\
\hline Nancy A. Hollmann & SNW & 19 & 5 & 14 & 1 \\
\hline Ronald D. Hollmann & SNW & 19 & 5 & 14 & 20 \\
\hline Nancy A. Hollmann & SNW & 19 & 5 & 15 & 1 \\
\hline Ronald D. Hollmann & SNW & 19 & 5 & 15 & 20 \\
\hline Dennis R. Carlton & SNW & 19 & 5 & 21 & 9 \\
\hline Nancy A. Hollmann & SNW & 19 & 5 & 22 & 1 \\
\hline Ronald D. Hollmann & SNW & 19 & 5 & 22 & 20 \\
\hline Nancy A. Hollmann & SNW & 19 & 5 & 23 & 1 \\
\hline Ronald D. Hollmann & SNW & 19 & 5 & 23 & 20 \\
\hline Nancy A. Hollmann & SNW & 19 & 5 & 24 & 1 \\
\hline Ronald D. Hollmann & SNW & 19 & 5 & 24 & 20 \\
\hline Nancy A. Hollmann & SNW & 19 & 5 & 25 & 1 \\
\hline Ronald D. Hollmann & SNW & 19 & 5 & 25 & 20 \\
\hline Nancy A. Hollmann & SNW & 19 & 5 & 26 & 1 \\
\hline
\end{tabular}




\section{STATE LAND APPLIED FOR UNDER SHALLOW NATURAL GAS LEASING PROGRAM}

\begin{tabular}{|c|c|c|c|c|c|}
\hline Applicant & $\mathbf{M}$ & $\mathbf{T}$ & $\mathbf{R}$ & Section & Priority \\
\hline Ronald D. Hollmann & SNW & 19 & 5 & 26 & 20 \\
\hline Nancy A. Hollmann & SNW & 19 & 5 & 27 & 1 \\
\hline Ronald D. Hollmann & SNW & 19 & 5 & 27 & 20 \\
\hline Dennis R. Carlton & SNW & 19 & 5 & 28 & 9 \\
\hline Dennis R. Carlton & SNW & 19 & 5 & 29 & 9 \\
\hline Dennis R. Carlton & SNW & 19 & 5 & 30 & 9 \\
\hline Dennis R. Carlton & SNW & 19 & 5 & 31 & 9 \\
\hline Dennis R. Carlton & SNW & 19 & 5 & 32 & 9 \\
\hline Dennis R. Carlton & SNW & 19 & 5 & 33 & 9 \\
\hline Nancy A. Hollmann & SNW & 19 & 5 & 34 & 1 \\
\hline Ronaid D. Hollmann & SNW & 19 & 5 & 34 & 20 \\
\hline Nancy A. Hollmann & SNW & 19 & 5 & 35 & 1 \\
\hline Ronald D. Hollmann & SNW & 19 & 5 & 35 & 20 \\
\hline Nancy A. Hollmann & SNW & 19 & 5 & 36 & 1 \\
\hline Ronald D. Hollmann & SNW & 19 & 5 & 36 & 20 \\
\hline Dennis R. Carlton & SNW & 19 & 6 & 25 & 9 \\
\hline Dennis R. Carlton & SNW & 19 & 6 & 36 & 9 \\
\hline William M. Fulton & SNW & 20 & 2 & 19 & 32 \\
\hline William M. Fulton & SNW & 20 & 2 & 20 & 32 \\
\hline William M. Fulton & SNW & 20 & 2 & 21 & 32 \\
\hline William M. Fulton & SNW & 20 & 2 & 28 & 32 \\
\hline William M. Fulton & SNW & 20 & 2 & 29 & 32 \\
\hline William M. Fulton & SNW & 20 & 2 & 30 & 32 \\
\hline William M. Fulton & SNW & 20 & 2 & 31 & 32 \\
\hline William M. Fulton & SNW & 20 & 2 & 32 & 32 \\
\hline William M. Fulton & SNW & 20 & 2 & 33 & 32 \\
\hline Ted H. Williams & SNW & 20 & 3 & 1 & 27 \\
\hline Ted H. Williams & SNW & 20 & 3 & 2 & 27 \\
\hline Ted H. Williams & SNW & 20 & 3 & 3 & 27 \\
\hline Evergreen Resources, Inc. & SNW & 20 & 3 & 4 & 11 \\
\hline Mark S. Sexton & SNW & 20 & 3 & 4 & 24 \\
\hline Ted H. Williams & SNW & 20 & 3 & 4 & 27 \\
\hline Evergreen Resources, Inc. & SNW & 20 & 3 & 5 & 11 \\
\hline Mark S. Sexton & SNW & 20 & 3 & 5 & 24 \\
\hline Ted H. Williams & SNW & 20 & 3 & 5 & 27 \\
\hline Evergreen Resources, Inc. & SNW & 20 & 3 & 6 & 11 \\
\hline Mark S. Sexton & SNW & 20 & 3 & 6 & 24 \\
\hline Ted H. Williams & SNW & 20 & 3 & 6 & 27 \\
\hline Evergreen Resources, Inc. & SNW & 20 & 3 & 7 & 11 \\
\hline Mark S. Sexton & SNW & 20 & 3 & 7 & 24 \\
\hline Ted H. Williams & SNW & 20 & 3 & 7 & 27 \\
\hline Evergreen Resources, Inc. & SNW & 20 & 3 & 8 & 11 \\
\hline Mark S. Sexton & SNW & 20 & 3 & 8 & 24 \\
\hline Ted H. Williams & SNW & 20 & 3 & 8 & 27 \\
\hline Evergreen Resources, Inc. & SNW & 20 & 3 & 9 & 11 \\
\hline Mark S. Sexton & SNW & 20 & 3 & 9 & 24 \\
\hline Ted H. Williams & SNW & 20 & 3 & 9 & 27 \\
\hline Ted H. Williams & SNW & 20 & 3 & 10 & 27 \\
\hline Ted H. Williams & SNW & 20 & 3 & 11 & 27 \\
\hline Ted H. Williams & SNW & 20 & 3 & 12 & 27 \\
\hline Ted H. Williams & SNW & 20 & 3 & 13 & 27 \\
\hline
\end{tabular}




\section{STATE LAND APPLIED FOR UNDER SHALLOW NATURAL GAS LEASING PROGRAM}

\begin{tabular}{|c|c|c|c|c|c|}
\hline Applicant & $\mathbf{M}$ & $T$ & $\mathbf{R}$ & Section & Priority \\
\hline Ted $\mathrm{H}$. Williams & SNW & 20 & 3 & 14 & 27 \\
\hline Ted H. Williams & SNW & 20 & 3 & 15 & 27 \\
\hline Evergreen Resources, Inc. & SNW & 20 & 3 & 16 & 11 \\
\hline Mark S. Sexton & SNW & 20 & 3 & 16 & 24 \\
\hline Ted H. Williams & SNW & 20 & 3 & 16 & 27 \\
\hline Evergreen Resources, Inc. & SNW & 20 & 3 & 17 & 11 \\
\hline Mark S. Sexton & SNW & 20 & 3 & 17 & 24 \\
\hline Ted H. Williams & SNW & 20 & 3 & 17 & 27 \\
\hline Evergreen Resources, Inc. & SNW & 20 & 3 & 18 & 11 \\
\hline Mark S. Sexton & SNW & 20 & 3 & 18 & 24 \\
\hline Ted H. Williams & SNW & 20 & 3 & 18 & 27 \\
\hline Evergreen Resources, Inc. & SNW & 20 & 3 & 19 & 11 \\
\hline Mark S. Sexton & SNW & 20 & 3 & 19 & 24 \\
\hline Ted $\mathrm{H}$. Williams & SNW & 20 & 3 & 19 & 27 \\
\hline Evergreen Resources, Inc. & SNW & 20 & 3 & 20 & 11 \\
\hline Mark S. Sexton & SNW & 20 & 3 & 20 & 24 \\
\hline Ted $\mathrm{H}$. Williams & SNW & 20 & 3 & 20 & 27 \\
\hline Evergreen Resources, Inc. & SNW & 20 & 3 & 21 & 11 \\
\hline Mark S. Sexton & SNW & 20 & 3 & 21 & 24 \\
\hline Ted H. Williams & SNW & 20 & 3 & 21 & 27 \\
\hline William M. Fulton & SNW & 20 & 3 & 22 & 32 \\
\hline William M. Fulton & SNW & 20 & 3 & 23 & 32 \\
\hline William M. Fulton & SNW & 20 & 3 & 24 & 32 \\
\hline William M. Fulton & SNW & 20 & 3 & 25 & 32 \\
\hline William M. Fulton & SNW & 20 & 3 & 26 & 32 \\
\hline William M. Fulton & SNW & 20 & 3 & 27 & 32 \\
\hline Evergreen Resources, Inc. & SNW & 20 & 3 & 28 & 11 \\
\hline Mark S. Sexton & SNW & 20 & 3 & 28 & 24 \\
\hline Ted H. Williams & SNW & 20 & 3 & 28 & 27 \\
\hline Evergreen Resources, Inc. & SNW & 20 & 3 & 29 & 11 \\
\hline Mark S. Sexton & SNW & 20 & 3 & 29 & 24 \\
\hline Ted H. Williams & SNW & 20 & 3 & 29 & 27 \\
\hline Evergreen Resources, Inc. & SNW & 20 & 3 & 30 & 11 \\
\hline Mark S. Sexton & SNW & 20 & 3 & 30 & 24 \\
\hline Ted H. Williams & SNW & 20 & 3 & 30 & 27 \\
\hline Evergreen Resources, Inc. & SNW & 20 & 3 & 31 & 11 \\
\hline Mark S. Sexton & SNW & 20 & 3 & 31 & 24 \\
\hline Ted H. Williams & SNW & 20 & 3 & 31 & 27 \\
\hline Evergreen Resources, Inc. & SNW & 20 & 3 & 32 & 11 \\
\hline Mark S. Sexton & SNW & 20 & 3 & 32 & 24 \\
\hline Ted H. Williams & SNW & 20 & 3 & 32 & 27 \\
\hline Evergreen Resources, Inc. & SNW & 20 & 3 & 33 & 11 \\
\hline Mark S. Sexton & SNW & 20 & 3 & 33 & 24 \\
\hline Ted H. Williams & SNW & 20 & 3 & 33 & 27 \\
\hline William M. Fulton & SNW & 20 & 3 & 35 & 32 \\
\hline William M. Fulton & SNW & 20 & 3 & 36 & 32 \\
\hline Evergreen Resources, Inc. & SNW & 20 & 4 & 1 & 11 \\
\hline Mark S. Sexton & SNW & 20 & 4 & 1 & 24 \\
\hline William M. Fulton & SNW & 20 & 4 & 1 & 32 \\
\hline Evergreen Resources, Inc. & SNW & 20 & 4 & 2 & 11 \\
\hline Mark S. Sexton & SNW & 20 & 4 & 2 & 24 \\
\hline
\end{tabular}




\section{Applicant}

William M. Fulton

Evergreen Resources, Inc. Mark S. Sexton

William M. Fulton

Evergreen Resources, Inc.

Mark S. Sexton

William M. Fulton

Evergreen Resources, Inc.

Mark S. Sexton

William M. Fulton

Evergreen Resources, Inc.

Mark S. Sexton

William M. Fulton

Evergreen Resources, Inc.

Mark S. Sexton

William M. Fulton

Evergreen Resources, Inc.

Mark S. Sexton

William M. Fulton

Evergreen Resources, Inc.

Mark S. Sexton

William M. Fulton

Evergreen Resources, Inc.

Mark S. Sexton

William M. Fulton

Evergreen Resources, Inc.

Mark S. Sexton

William M. Fulton

Evergreen Resources, Inc.

Mark S. Sexton

William M. Fulton

Evergreen Resources, Inc.

Mark S. Sexton

William M. Fulton

Evergreen Resources, Inc.

Mark S. Sexton

William M. Fulton

Evergreen Resources, Inc.

Mark S. Sexton

William M. Fulton

Evergreen Resources, Inc.

Mark S. Sexton

William M. Fulton

Evergreen Resources, Inc.

Mark S. Sexton

William M. Fulton

Evergreen Resources, Inc.

Mark S. Sexton

William M. Fulton

Evergreen Resources, Inc.

Mark S. Sexton

\section{$\begin{array}{lllll}\text { M } & \text { T } & \text { R } & \text { Section } & \text { Priority }\end{array}$}

$\begin{array}{lllll}\text { SNW } & 20 & 4 & 2 & 32\end{array}$

$\begin{array}{lllll}\text { SNW } & 20 & 4 & 3 & 11\end{array}$

$\begin{array}{lllll}\text { SNW } & 20 & 4 & 3 & 24\end{array}$

$\begin{array}{lllll}\text { SNW } & 20 & 4 & 3 & 32\end{array}$

$\begin{array}{lllll}\text { SNW } & 20 & 4 & 4 & 11\end{array}$

$\begin{array}{lllll}\text { SNW } & 20 & 4 & 4 & 24\end{array}$

$\begin{array}{lllll}\text { SNW } & 20 & 4 & 4 & 32\end{array}$

$\begin{array}{lllll}\text { SNW } & 20 & 4 & 5 & 11\end{array}$

$\begin{array}{lllll}\text { SNW } & 20 & 4 & 5 & 24\end{array}$

$\begin{array}{lllll}\text { SNW } & 20 & 4 & 5 & 32\end{array}$

$\begin{array}{lllll}\text { SNW } & 20 & 4 & 6 & 11\end{array}$

$\begin{array}{lllll}\text { SNW } & 20 & 4 & 6 & 24\end{array}$

$\begin{array}{lllll}\text { SNW } & 20 & 4 & 6 & 32\end{array}$

$\begin{array}{lllll}\text { SNW } & 20 & 4 & 7 & 11\end{array}$

$\begin{array}{lllll}\text { SNW } & 20 & 4 & 7 & 24\end{array}$

$\begin{array}{lllll}\text { SNW } & 20 & 4 & 7 & 32\end{array}$

$\begin{array}{lllll}\text { SNW } & 20 & 4 & 8 & 11\end{array}$

$\begin{array}{lllll}\text { SNW } & 20 & 4 & 8 & 24\end{array}$

$\begin{array}{lllll}\text { SNW } & 20 & 4 & 8 & 32\end{array}$

$\begin{array}{lllll}\text { SNW } & 20 & 4 & 9 & 11\end{array}$

$\begin{array}{lllll}\text { SNW } & 20 & 4 & 9 & 24\end{array}$

$\begin{array}{lllll}\text { SNW } & 20 & 4 & 9 & 32\end{array}$

$\begin{array}{lllll}\text { SNW } & 20 & 4 & 10 & 11\end{array}$

$\begin{array}{lllll}\text { SNW } & 20 & 4 & 10 & 24\end{array}$

$\begin{array}{lllll}\text { SNW } & 20 & 4 & 10 & 32\end{array}$

$\begin{array}{lllll}\text { SNW } & 20 & 4 & 11 & 11\end{array}$

$\begin{array}{lllll}\text { SNW } & 20 & 4 & 11 & 24\end{array}$

$\begin{array}{lllll}\text { SNW } & 20 & 4 & 11 & 32\end{array}$

$\begin{array}{lllll}\text { SNW } & 20 & 4 & 12 & 11\end{array}$

$\begin{array}{lllll}\text { SNW } & 20 & 4 & 12 & 24\end{array}$

$\begin{array}{lllll}\text { SNW } & 20 & 4 & 12 & 32\end{array}$

$\begin{array}{lllll}\text { SNW } & 20 & 4 & 13 & 11\end{array}$

$\begin{array}{lllll}\text { SNW } & 20 & 4 & 13 & 24\end{array}$

$\begin{array}{lllll}\text { SNW } & 20 & 4 & 13 & 32\end{array}$

$\begin{array}{lllll}\text { SNW } & 20 & 4 & 14 & 11\end{array}$

$\begin{array}{lllll}\text { SNW } & 20 & 4 & 14 & 24\end{array}$

$\begin{array}{lllll}\text { SNW } & 20 & 4 & 14 & 32\end{array}$

$\begin{array}{lllll}\text { SNW } & 20 & 4 & 15 & 11\end{array}$

$\begin{array}{lllll}\text { SNW } & 20 & 4 & 15 & 24\end{array}$

$\begin{array}{lllll}\text { SNW } & 20 & 4 & 15 & 32\end{array}$

$\begin{array}{lllll}\text { SNW } & 20 & 4 & 16 & 11\end{array}$

$\begin{array}{lllll}\text { SNW } & 20 & 4 & 16 & 24\end{array}$

$\begin{array}{lllll}\text { SNW } & 20 & 4 & 16 & 32\end{array}$

$\begin{array}{lllll}\text { SNW } & 20 & 4 & 17 & 11\end{array}$

$\begin{array}{lllll}\text { SNW } & 20 & 4 & 17 & 24\end{array}$

$\begin{array}{lllll}\text { SNW } & 20 & 4 & 17 & 32\end{array}$

$\begin{array}{lllll}\text { SNW } & 20 & 4 & 18 & 11\end{array}$

$\begin{array}{lllll}\text { SNW } & 20 & 4 & 18 & 24\end{array}$

$\begin{array}{lllll}\text { SNW } & 20 & 4 & 18 & 32\end{array}$

$\begin{array}{lllll}\text { SNW } & 20 & 4 & 19 & 11\end{array}$

SNW 20

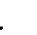

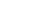

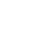

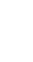

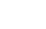

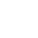

4

11

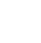

(1)

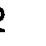

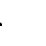

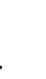

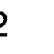

4

1

32

4

2

4

1

4

1

24

1


STATE LAND APPLIED FOR UNDER SHALLOW NATURAL GAS LEASING PROGRAM

\section{Applicant}

William M. Fulton

Evergreen Resources, Inc.

Mark S. Sexton

William M. Fulton

Evergreen Resources, Inc.

Mark S. Sexton

William M. Fulton

Evergreen Resources, Inc.

Mark S. Sexton

William M. Fulton

Evergreen Resources, Inc.

Mark S. Sexton

William M. Fulton

Evergreen Resources, Inc.

Mark S. Sexton

William M. Fulton

Evergreen Resources, Inc.

Mark S. Sexton

William M. Fulton

Evergreen Resources, Inc.

Mark S. Sexton

William M. Fulton

Evergreen Resources, Inc.

Mark S. Sexton

William M. Fulton

Evergreen Resources, Inc.

Mark S. Sexton

William M. Fulton

Evergreen Resources, Inc.

Mark S. Sexton

William M. Fulton

Evergreen Resources, Inc.

Mark S. Sexton

William M. Fulton

Evergreen Resources, Inc.

Mark S. Sexton

William M. Fulton

Evergreen Resources, Inc.

Mark S. Sexton

William M. Fulton

Evergreen Resources, Inc.

Mark S. Sexton

William M. Fulton

Evergreen Resources, Inc.

Mark S. Sexton

William M. Fulton

Evergreen Resources, Inc.

Mark S. Sexton

William M. Fulton

Evergreen Resources, Inc.

Mark S. Sexton

\begin{tabular}{|c|c|}
\hline $\mathbf{M}$ & $\mathbf{T}$ \\
\hline SNW & 20 \\
\hline SNW & 20 \\
\hline SNW & 20 \\
\hline SNW & 20 \\
\hline SNW & 20 \\
\hline SNW & 20 \\
\hline SNW & 20 \\
\hline SNW & 20 \\
\hline SNW & 20 \\
\hline SNW & 20 \\
\hline SNW & 20 \\
\hline SNW & 20 \\
\hline SNW & 20 \\
\hline SNW & 20 \\
\hline SNW & 20 \\
\hline SNW & 20 \\
\hline SNW & 20 \\
\hline SNW & 20 \\
\hline SNW & 20 \\
\hline SNW & 20 \\
\hline SNW & 20 \\
\hline SNW & 20 \\
\hline SNW & 20 \\
\hline SNW & 20 \\
\hline SNW & 20 \\
\hline SNW & 20 \\
\hline SNW & 20 \\
\hline SNW & 20 \\
\hline SNW & 20 \\
\hline SNW & 20 \\
\hline SNW & 20 \\
\hline SNW & 20 \\
\hline SNW & 20 \\
\hline SNW & 20 \\
\hline SNW & 20 \\
\hline SNW & 20 \\
\hline SNW & 20 \\
\hline SNW & 20 \\
\hline SNW & 20 \\
\hline SNW & 20 \\
\hline SNW & 20 \\
\hline SNW & 20 \\
\hline SNW & 20 \\
\hline SNW & 20 \\
\hline SNW & 20 \\
\hline SNW & 20 \\
\hline SNW & 20 \\
\hline SNW & 20 \\
\hline SNW & 20 \\
\hline SNW & 20 \\
\hline SNW & 20 \\
\hline
\end{tabular}

Priority

32

11

24

32

11

24

32

11

24

32

11

24

32

11

24

32

11

24

32

11 


\begin{tabular}{|c|c|c|c|c|c|}
\hline Applicant & $\mathbf{M}$ & $\mathbf{T}$ & $\mathbf{R}$ & Section & Priority \\
\hline William M. Fulton & SNW & 20 & 4 & 36 & 32 \\
\hline Evergreen Resources, Inc. & SNW & 20 & 5 & 1 & 11 \\
\hline Mark S. Sexton & SNW & 20 & 5 & 1 & 24 \\
\hline Evergreen Resources, Inc. & SNW & 20 & 5 & 12 & 11 \\
\hline Mark S. Sexton & SNW & 20 & 5 & 12 & 24 \\
\hline Evergreen Resources, Inc. & SNW & 20 & 5 & 13 & 11 \\
\hline Mark S. Sexton & SNW & 20 & 5 & 13 & 24 \\
\hline Evergreen Resources, Inc. & SNW & 20 & 5 & 14 & 11 \\
\hline Mark S. Sexton & SNW & 20 & 5 & 14 & 24 \\
\hline Evergreen Resources, Inc. & SNW & 20 & 5 & 23 & 11 \\
\hline Mark S. Sexton & SNW & 20 & 5 & 23 & 24 \\
\hline Evergreen Resources, Inc. & SNW & 20 & 5 & 24 & 11 \\
\hline Mark S. Sexton & SNW & 20 & 5 & 24 & 24 \\
\hline Evergreen Resources, Inc. & SNW & 20 & 5 & 25 & 11 \\
\hline Mark S. Sexton & SNW & 20 & 5 & 25 & 24 \\
\hline Evergreen Resources, Inc. & SNW & 20 & 5 & 26 & 11 \\
\hline Mark S. Sexton & SNW & 20 & 5 & 26 & 24 \\
\hline Evergreen Resources, Inc. & SNW & 20 & 5 & 36 & 11 \\
\hline Kevin R. Collins & SNW & 21 & 3 & 4 & 10 \\
\hline Kevin R. Collins & SNW & 21 & 3 & 5 & 10 \\
\hline Kevin R. Collins & SNW & 21 & 3 & 6 & 10 \\
\hline Kevin R. Collins & SNW & 21 & 3 & 7 & 10 \\
\hline Kevin R. Collins & SNW & 21 & 3 & 8 & 10 \\
\hline Kevin R. Collins & SNW & 21 & 3 & 9 & 10 \\
\hline Kevin R. Collins & SNW & 21 & 3 & 16 & 10 \\
\hline Kevin R. Collins & SNW & 21 & 3 & 17 & 10 \\
\hline Kevin R. Collins & SNW & 21 & 3 & 18 & 10 \\
\hline Kevin R. Collins & SNW & 21 & 3 & 19 & 10 \\
\hline Kevin R. Collins & SNW & 21 & 3 & 20 & 10 \\
\hline Kevin R. Collins & SNW & 21 & 3 & 21 & 10 \\
\hline Kevin R. Collins & SNW & 21 & 3 & 28 & 10 \\
\hline Kevin R. Collins & SNW & 21 & 3 & 29 & 10 \\
\hline Kevin R. Collins & SNW & 21 & 3 & 30 & 10 \\
\hline Kevin R. Collins & SNW & 21 & 3 & 31 & 10 \\
\hline Kevin R. Collins & SNW & 21 & 3 & 32 & 10 \\
\hline Kevin R. Collins & SNW & 21 & 3 & 33 & 10 \\
\hline Kevin R. Collins & SNW & 21 & 4 & 1 & 10 \\
\hline Kevin R. Collins & SNW & 21 & 4 & 2 & 10 \\
\hline Kevin R. Collins & SNW & 21 & 4 & 3 & 10 \\
\hline Kevin R. Collins & SNW & 21 & 4 & 4 & 10 \\
\hline Kevin R. Collins & SNW & 21 & 4 & 5 & 10 \\
\hline Kevin R. Collins & SNW & 21 & 4 & 6 & 10 \\
\hline Kevin R. Collins & SNW & 21 & 4 & 7 & 10 \\
\hline Kevin R. Collins & SNW & 21 & 4 & 8 & 10 \\
\hline Kevin R. Collins & SNW & 21 & 4 & 9 & 10 \\
\hline Kevin R. Collins & SNW & 21 & 4 & 10 & 10 \\
\hline Kevin R. Collins & SNW & 21 & 4 & 11 & 10 \\
\hline Kevin R. Collins & SNW & 21 & 4 & 12 & 10 \\
\hline Kevin R. Collins & SNW & 21 & 4 & 13 & 10 \\
\hline Kevin R. Collins & SNW & 21 & 4 & 14 & 10 \\
\hline Kevin R. Collins & SNW & 21 & 4 & 15 & 10 \\
\hline
\end{tabular}


STATE LAND APPLIED FOR UNDER SHALLOW NATURAL GAS LEASING PROGRAM

\section{Applicant}

Kevin R. Collins

Kevin R. Collins

Kevin R. Collins

Dennis R. Carlton

Kevin R. Collins

Kevin R. Collins

Kevin R. Collins

Kevin R. Collins

Kevin R. Collins

Kevin R. Collins

Dennis R. Carlton

Dennis R. Carlton

Dennis R. Carlton

Dennis R. Cariton

Dennis R. Carlton

Dennis R. Cariton

Dennis R. Carlton

Dennis R. Carlton

Kevin R. Collins

Kevin R. Collins

Kevin R. Collins

Mark S. Sexton

Kevin R. Collins

Kevin R. Collins

Kevin R. Collins

Kevin R. Collins

Kevin R. Collins

Kevin R. Collins

Kevin R. Collins

Kevin R. Collins

Kevin R. Collins

Kevin R. Collins

Kevin R. Collins

Kevin R. Collins

Kevin R. Collins

Kevin R. Collins

Kevin R. Collins

Kevin R. Collins

Kevin R. Collins

Kevin R. Collins

Kevin R. Collins

Kevin R. Collins

Kevin R. Collins

Kevin R. Collins

Kevin R. Collins

Kevin R. Collins

Kevin R. Collins

Kevin R. Collins

Kevin R. Collins

Raymond R. Latchem

Raymond R. Latchem

\begin{tabular}{|c|c|c|c|c|}
\hline $\mathbf{M}$ & $\mathbf{T}$ & $\mathbf{R}$ & Section & Priority \\
\hline SNW & 21 & 4 & 16 & 10 \\
\hline SNW & 21 & 4 & 17 & 10 \\
\hline SNW & 21 & 4 & 18 & 10 \\
\hline SNW & 21 & 4 & 19 & 9 \\
\hline SNW & 21 & 4 & 22 & 10 \\
\hline SNW & 21 & 4 & 23 & 10 \\
\hline SNW & 21 & 4 & 24 & 10 \\
\hline SNW & 21 & 4 & 25 & 10 \\
\hline SNW & 21 & 4 & 26 & 10 \\
\hline SNW & 21 & 4 & 27 & 10 \\
\hline SNW & 21 & 4 & 28 & 9 \\
\hline SNW & 21 & 4 & 29 & 9 \\
\hline SNW & 21 & 4 & 30 & 9 \\
\hline SNW & 21 & 4 & 30 & 9 \\
\hline SNW & 21 & 4 & 31 & 9 \\
\hline SNW & 21 & 4 & 31 & 9 \\
\hline SNW & 21 & 4 & 32 & 9 \\
\hline SNW & 21 & 4 & 33 & 9 \\
\hline SNW & 21 & 4 & 34 & 10 \\
\hline SNW & 21 & 4 & 35 & 10 \\
\hline SNW & 21 & 4 & 36 & 10 \\
\hline SNW & 21 & 5 & 36 & 24 \\
\hline SNW & 22 & 3 & 19 & 10 \\
\hline SNW & 22 & 3 & 20 & 10 \\
\hline SNW & 22 & 3 & 21 & 10 \\
\hline SNW & 22 & 3 & 28 & 10 \\
\hline SNW & 22 & 3 & 29 & 10 \\
\hline SNW & 22 & 3 & 30 & 10 \\
\hline SNW & 22 & 3 & 31 & 10 \\
\hline SNW & 22 & 3 & 32 & 10 \\
\hline SNW & 22 & 3 & 33 & 10 \\
\hline SNW & 22 & 4 & 19 & 10 \\
\hline SNW & 22 & 4 & 20 & 10 \\
\hline SNW & 22 & 4 & 21 & 10 \\
\hline SNW & 22 & 4 & 22 & 10 \\
\hline SNW & 22 & 4 & 23 & 10 \\
\hline SNW & 22 & 4 & 24 & 10 \\
\hline SNW & 22 & 4 & 25 & 10 \\
\hline SNW & 22 & 4 & 26 & 10 \\
\hline SNW & 22 & 4 & 27 & 10 \\
\hline SNW & 22 & 4 & 28 & 10 \\
\hline SNW & 22 & 4 & 29 & 10 \\
\hline SNW & 22 & 4 & 30 & 10 \\
\hline SNW & 22 & 4 & 31 & 10 \\
\hline SNW & 22 & 4 & 32 & 10 \\
\hline SNW & 22 & 4 & 33 & 10 \\
\hline SNW & 22 & 4 & 34 & 10 \\
\hline SNW & 22 & 4 & 35 & 10 \\
\hline SNW & 22 & 4 & 36 & 10 \\
\hline SNW & 25 & 4 & 5 & 21 \\
\hline SNW & 25 & 4 & 6 & 21 \\
\hline
\end{tabular}




\section{Applicant}

Raymond R. Latchem

Raymond R. Latchem

Raymond R. Latchem

Raymond R. Latchem

Raymond R. Latchem

Raymond R. Latchem

Raymond R. Latchem

Raymond R. Latchem

Raymond R. Latchem

Raymond R. Latchem

Raymond R. Latchem

Raymond R. Latchem

Raymond R. Latchem

Raymond R. Latchem

Raymond R. Latchem

Raymond R. Latchem

LAPP Resources, Inc. LAPP Resources, Inc. LAPP Resources, Inc. LAPP Resources, Inc. LAPP Resources, Inc. LAPP Resources, Inc. LAPP Resources, Inc. LAPP Resources, Inc. LAPP Resources, Inc. LAPP Resources, Inc. LAPP Resources, Inc. LAPP Resources, Inc. LAPP Resources, Inc. LAPP Resources, Inc. LAPP Resources, Inc. LAPP Resources, Inc. LAPP Resources, Inc. LAPP Resources, Inc. LAPP Resources, Inc. LAPP Resources, Inc. LAPP Resources, Inc. LAPP Resources, Inc. LAPP Resources, Inc. LAPP Resources, Inc. LAPP Resources, Inc. LAPP Resources, Inc. LAPP Resources, Inc. LAPP Resources, Inc. LAPP Resources, Inc. LAPP Resources, Inc. LAPP Resources, Inc. LAPP Resources, Inc. LAPP Resources, Inc. LAPP Resources, Inc.

\begin{tabular}{|c|c|c|c|c|}
\hline $\mathbf{M}$ & $\mathrm{T}$ & $\mathbf{R}$ & Section & Priority \\
\hline SNW & 25 & 4 & 7 & 21 \\
\hline SNW & 25 & 4 & 8 & 21 \\
\hline SNW & 25 & 4 & 17 & 21 \\
\hline SNW & 25 & 4 & 18 & 21 \\
\hline SNW & 26 & 4 & 19 & 21 \\
\hline SNW & 26 & 4 & 30 & 21 \\
\hline SNW & 26 & 4 & 31 & 21 \\
\hline SNW & 29 & 5 & 19 & 21 \\
\hline SNW & 29 & 5 & 20 & 21 \\
\hline SNW & 29 & 5 & 21 & 21 \\
\hline SNW & 29 & 5 & 28 & 21 \\
\hline SNW & 29 & 5 & 29 & 21 \\
\hline SNW & 29 & 5 & 30 & 21 \\
\hline SNW & 29 & 5 & 31 & 21 \\
\hline SNW & 29 & 5 & 32 & 21 \\
\hline SNW & 29 & 5 & 33 & 21 \\
\hline SSW & 5 & 12 & 14 & 4 \\
\hline SSW & 5 & 12 & 15 & 4 \\
\hline SSW & 5 & 12 & 16 & 4 \\
\hline SSW & 5 & 12 & 21 & 4 \\
\hline SSW & 5 & 12 & 22 & 4 \\
\hline SSW & 5 & 12 & 23 & 4 \\
\hline SSW & 5 & 12 & 26 & 4 \\
\hline SSW & 5 & 12 & 27 & 4 \\
\hline SSW & 5 & 12 & 28 & 4 \\
\hline SSW & 5 & 12 & 29 & 4 \\
\hline SSW & 5 & 12 & 30 & 4 \\
\hline SSW & 5 & 12 & 31 & 4 \\
\hline SSW & 5 & 12 & 32 & 4 \\
\hline SSW & 5 & 12 & 33 & 4 \\
\hline SSW & 5 & 12 & 34 & 4 \\
\hline SSW & 5 & 13 & 25 & 4 \\
\hline SSW & 5 & 13 & 26 & 4 \\
\hline SSW & 5 & 13 & 27 & 4 \\
\hline SSW & 5 & 13 & 28 & 4 \\
\hline SSW & 5 & 13 & 29 & 4 \\
\hline SSW & 5 & 13 & 30 & 4 \\
\hline SSW & 5 & 13 & 31 & 4 \\
\hline SSW & 5 & 13 & 32 & 4 \\
\hline SSW & 5 & 13 & 33 & 4 \\
\hline SSW & 5 & 13 & 34 & 4 \\
\hline SSW & 5 & 13 & 35 & 4 \\
\hline SSW & 5 & 13 & 36 & 4 \\
\hline SSW & 5 & 14 & 30 & 4 \\
\hline SSW & 5 & 14 & 31 & 4 \\
\hline SSW & 5 & 14 & 32 & 4 \\
\hline SSW & 5 & 14 & 33 & 4 \\
\hline SSW & 5 & 14 & 34 & 4 \\
\hline SSW & 5 & 14 & 35 & 4 \\
\hline SSW & 5 & 14 & 36 & 4 \\
\hline
\end{tabular}




\section{STATE LAND APPLIED FOR UNDER}

\section{SHALLOW NATURAL GAS LEASING PROGRAM}

\begin{tabular}{|c|c|c|c|c|c|}
\hline Applicant & $\mathbf{M}$ & $\mathbf{T}$ & $\mathbf{R}$ & Section & Priority \\
\hline LAPP Resources, Inc. & SSW & 5 & 15 & 21 & 4 \\
\hline LAPP Resources, Inc. & SSW & 5 & 15 & 22 & 4 \\
\hline LAPP Resources, Inc. & SSW & 5 & 15 & 23 & 4 \\
\hline LAPP Resources, Inc. & SSW & 5 & 15 & 24 & 4 \\
\hline LAPP Resources, Inc. & SSW & 5 & 15 & 25 & 4 \\
\hline LAPP Resources, Inc. & SSW & 5 & 15 & 26 & 4 \\
\hline LAPP Resources, Inc. & SSW & 5 & 15 & 27 & 4 \\
\hline LAPP Resources, Inc. & SSW & 5 & 15 & 35 & 4 \\
\hline LAPP Resources, Inc. & SSW & 5 & 15 & 36 & 4 \\
\hline LAPP Resources, Inc. & SSW & 6 & 12 & 4 & 4 \\
\hline LAPP Resources, Inc. & SSW & 6 & 12 & 5 & 4 \\
\hline LAPP Resources, Inc. & SSW & 6 & 12 & 6 & 4 \\
\hline LAPP Resources, Inc. & SSW & 6 & 13 & 1 & 4 \\
\hline LAPP Resources, Inc. & SSW & 6 & 13 & 2 & 4 \\
\hline LAPP Resources, Inc. & SSW & 6 & 13 & 3 & 4 \\
\hline LAPP Resources, Inc. & SSW & 6 & 13 & 4 & 4 \\
\hline LAPP Resources, Inc. & SSW & 6 & 13 & 5 & 4 \\
\hline LAPP Resources, Inc. & SSW & 6 & 13 & 6 & 4 \\
\hline LAPP Resources, Inc. & SSW & 6 & 13 & 7 & 4 \\
\hline LAPP Resources, Inc. & SSW & 6 & 13 & 8 & 4 \\
\hline LAPP Resources, Inc. & SSW & 6 & 13 & 9 & 4 \\
\hline LAPP Resources, Inc. & SSW & 6 & 13 & 10 & 4 \\
\hline LAPP Resources, Inc. & SSW & 6 & 13 & 11 & 4 \\
\hline LAPP Resources, Inc. & SSW & 6 & 13 & 12 & 4 \\
\hline LAPP Resources, Inc. & SSW & 6 & 13 & 14 & 4 \\
\hline LAPP Resources, Inc. & SSW & 6 & 13 & 15 & 4 \\
\hline LAPP Resources, Inc. & SSW & 6 & 13 & 16 & 4 \\
\hline LAPP Resources, Inc. & SSW & 6 & 14 & 1 & 4 \\
\hline LAPP Resources, Inc. & SSW & 6 & 14 & 2 & 4 \\
\hline LAPP Resources, Inc. & SSW & 6 & 14 & 3 & 4 \\
\hline LAPP Resources, Inc. & SSW & 6 & 14 & 4 & 4 \\
\hline LAPP Resources, Inc. & SSW & 6 & 14 & 5 & 4 \\
\hline LAPP Resources, Inc. & SSW & 6 & 14 & 6 & 4 \\
\hline LAPP Resources, Inc. & SSW & 6 & 14 & 8 & 4 \\
\hline LAPP Resources, Inc. & SSW & 6 & 14 & 9 & 4 \\
\hline LAPP Resources, Inc. & SSW & 6 & 14 & 10 & 4 \\
\hline LAPP Resources, Inc. & SSW & 6 & 14 & 11 & 4 \\
\hline LAPP Resources, Inc. & SSW & 6 & 14 & 12 & 4 \\
\hline
\end{tabular}




\section{CBM Exploration and Development on Federal Lands}

Bob Fisk

U.S. Bureau of Land Management, Alaska 


\section{Speaker Biography}

\section{Bob Fisk}

Mr. Fisk earned his Bachelor of Science degree in Petroleum and Geological Engineering. He spent 6 years with the University of Alaska, Fairbanks and he conducted studies in subsea permafrost and the impacts on proposed oil and gas development. He has been with the Bureau of Land Management, Alaska State Office for 16 years in both fluid and solid minerals programs. Mr. Fisk is currently the Program Manager for Solid Minerals and Coalbed Methane at the Bureau of Land Management. 


\section{CBM Exploration and Development on Federal Lands}

As the investigation for CBM source rocks progresses there comes the time when its necessary to physically drill the target and test the resource. This paper will discuss whats necessary for the permitting for exploration and development of coalbed methane on federal lands. 


\section{COALBED METHANE}

\section{EXPLORATION AND DEVELOPMENT}

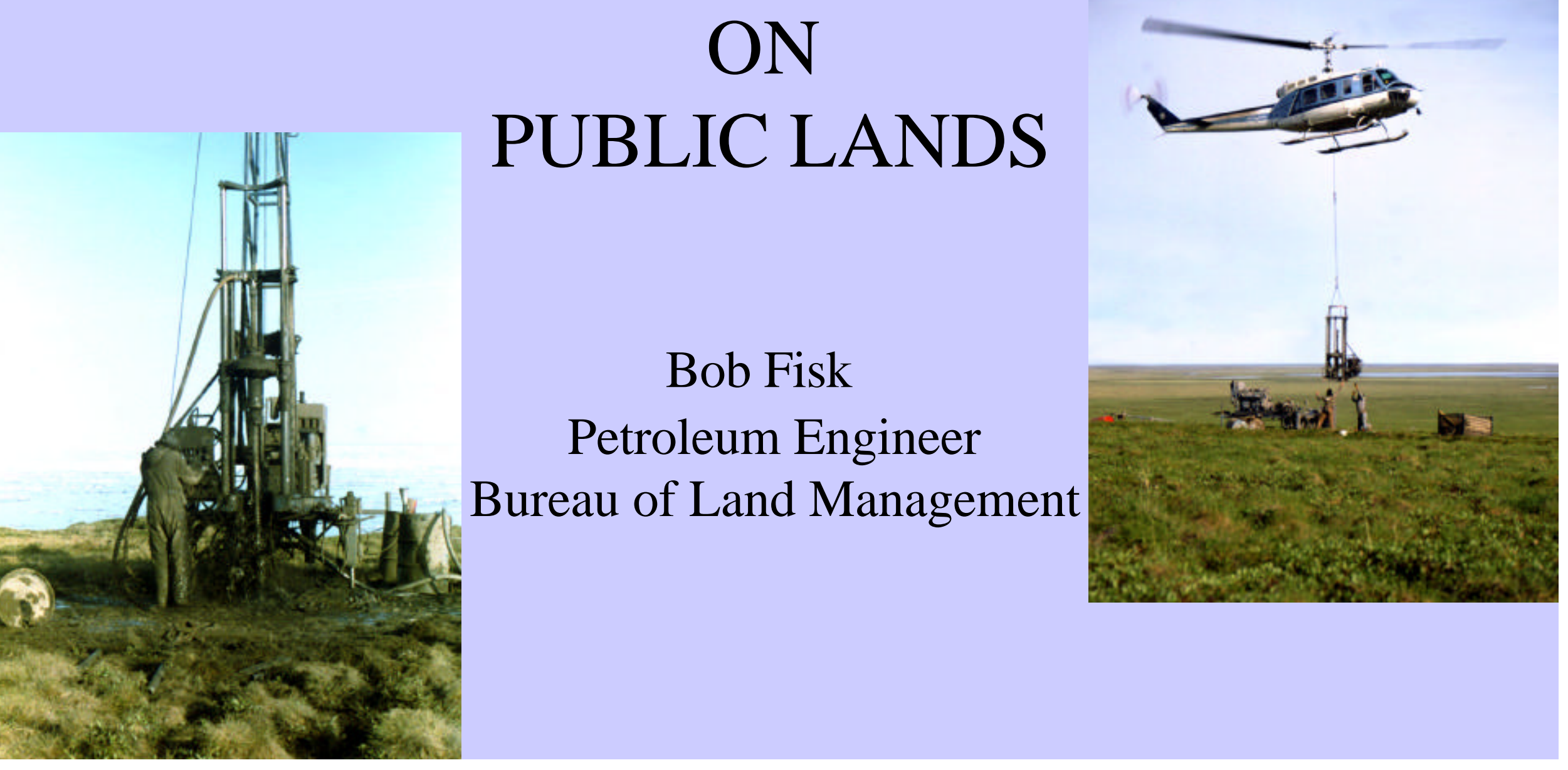




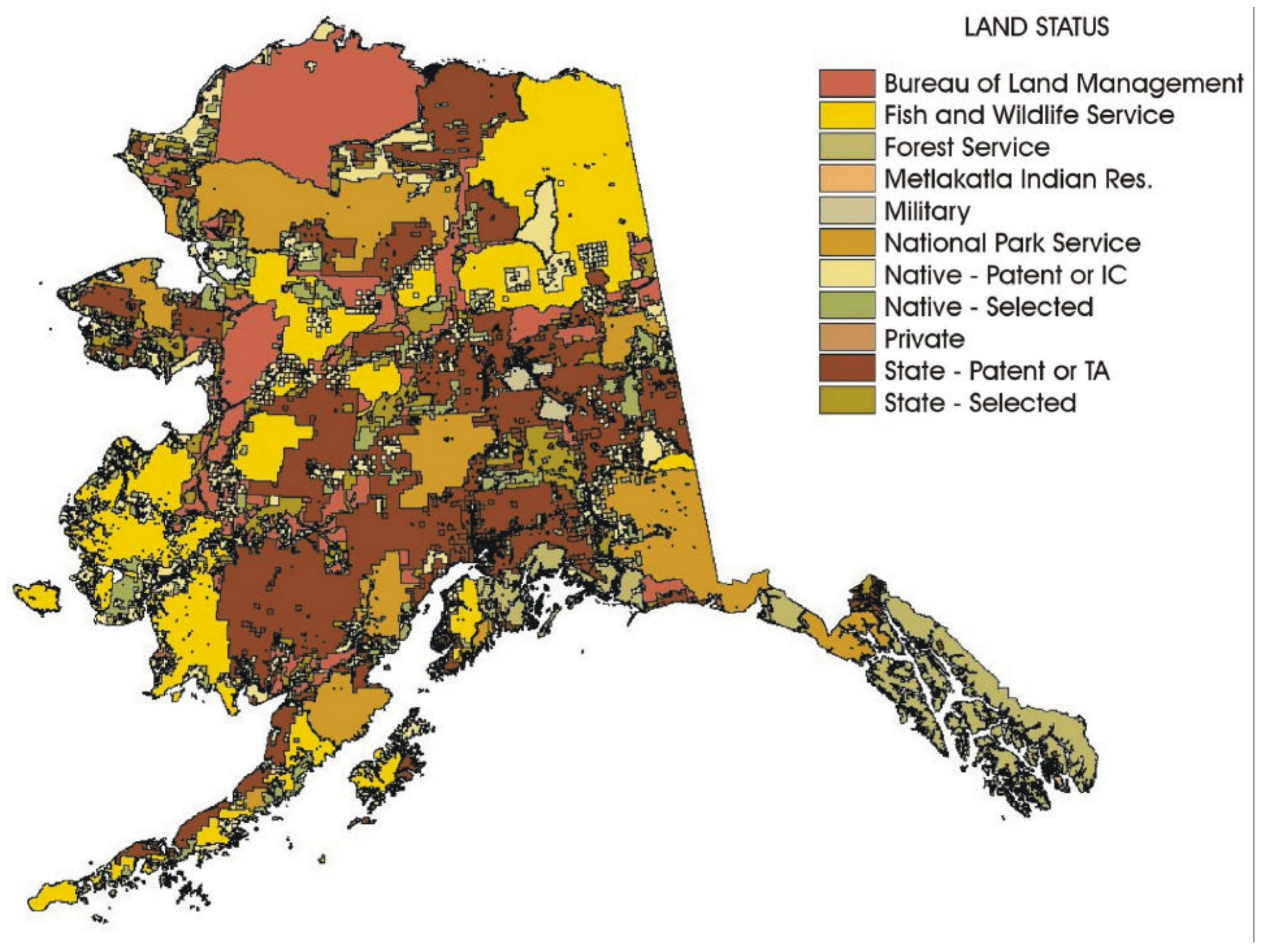




\section{SELECTED LAND STATUS}

Native Selected

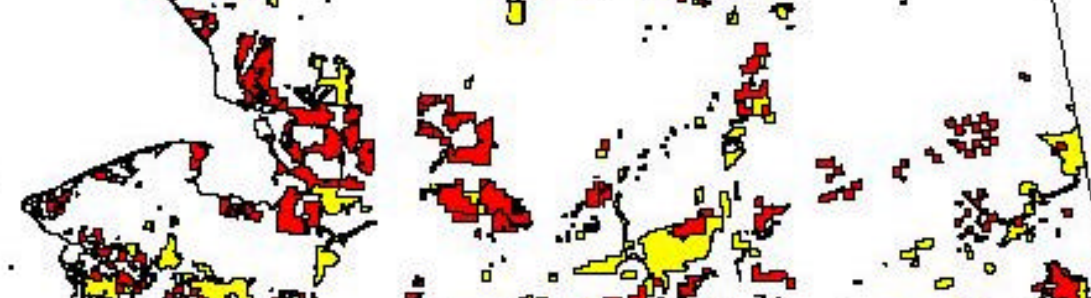

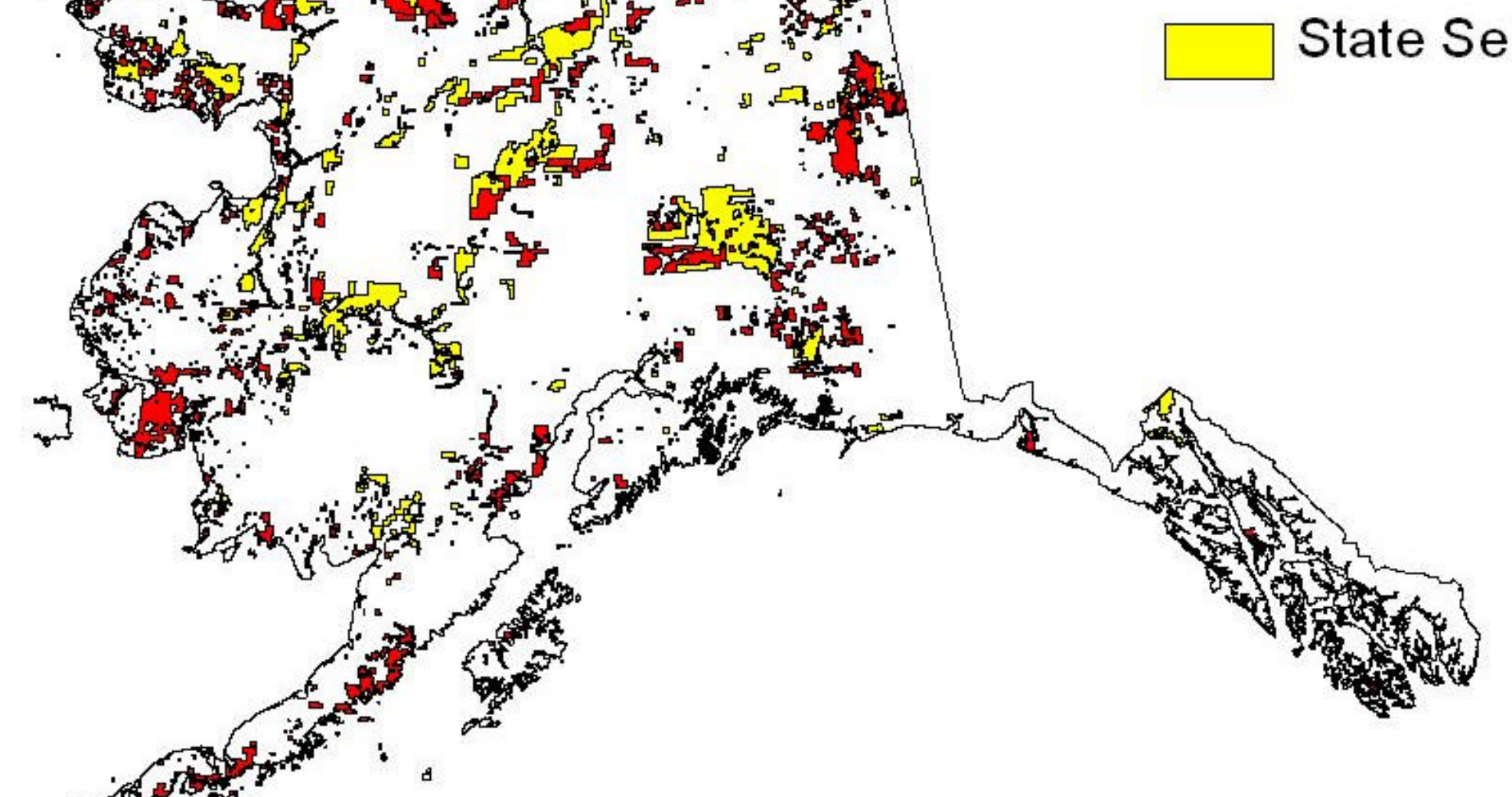


Two very important pieces of legislation dictate conditions and uses of certain federal lands within Alaska:

- ALASKA NATIVE CLAIMS SETTLEMENT ACT (ANCSA). Passed on December 18, 1971. This legislation acknowledges the rights of Natives and Native groups.

- ALASKA NATIONAL INTEREST LANDS CONSERVATION ACT (ANILCA). Passed on

December 2, 1980. This legislation set aside lands in the State of Alaska for special designation and conservation. It created special use areas and additions to the National Park system and Wildlife Refuges, plus numerous other designations. 


\section{ANCSA and ANILCA}

- prohibit most minerals activities or

- severely limit how those activities are conducted

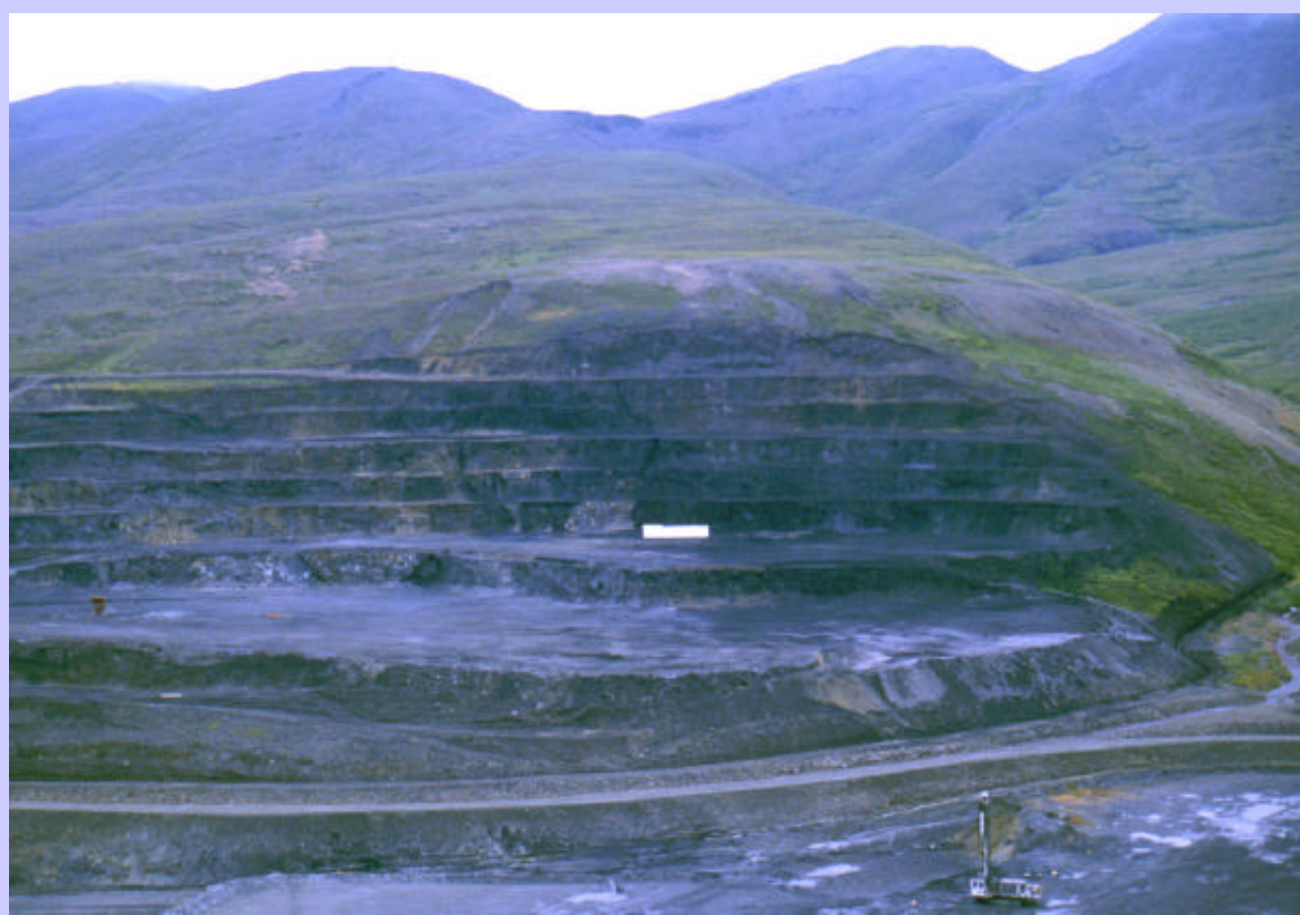




\section{Mineral-related activities:}

- prohibited in the National Park Service unless there is a valid existing right

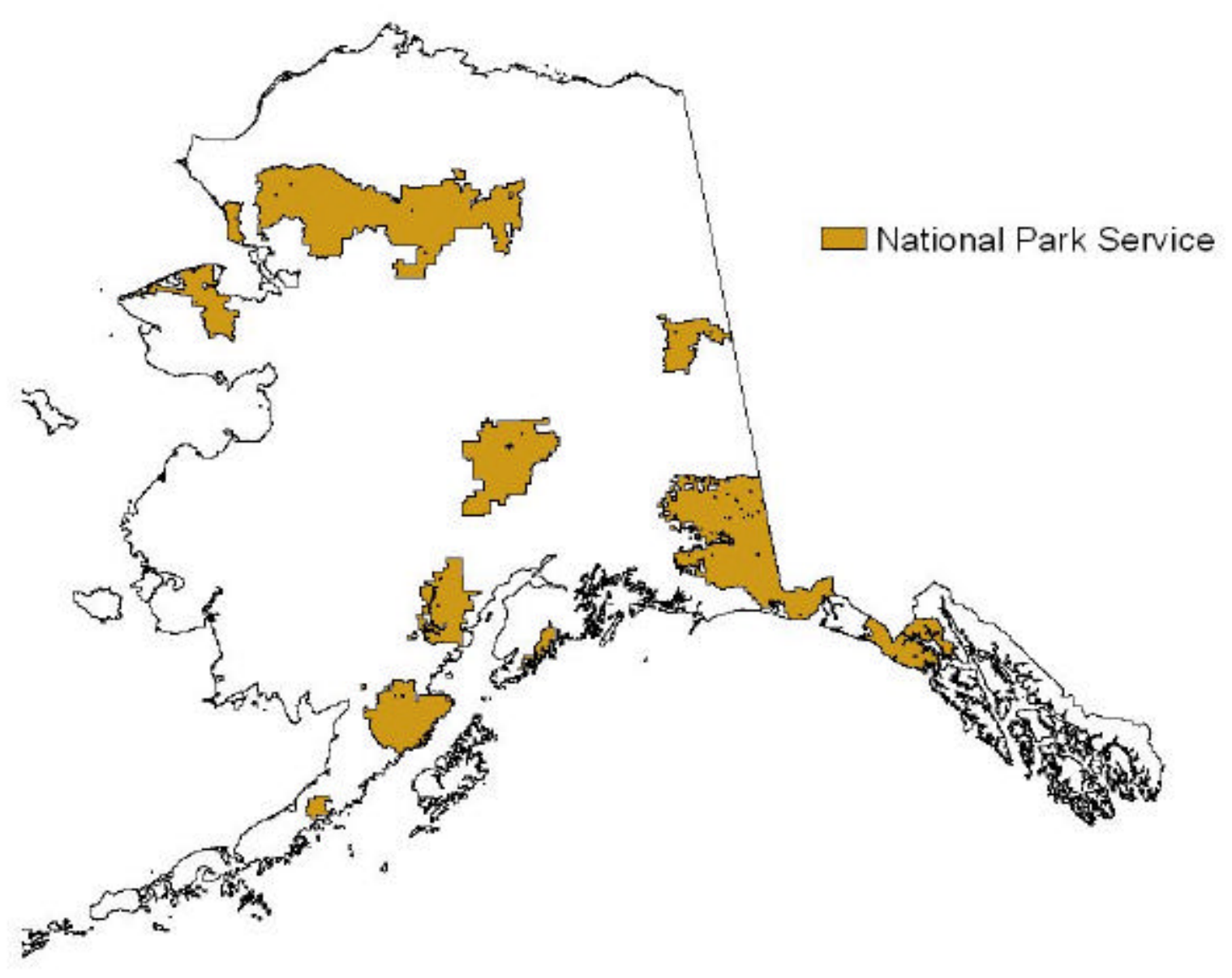




\section{Mineral-related activities:}

- Forest Service and Fish and Wildlife Service do not have areas open to mineral exploration and development

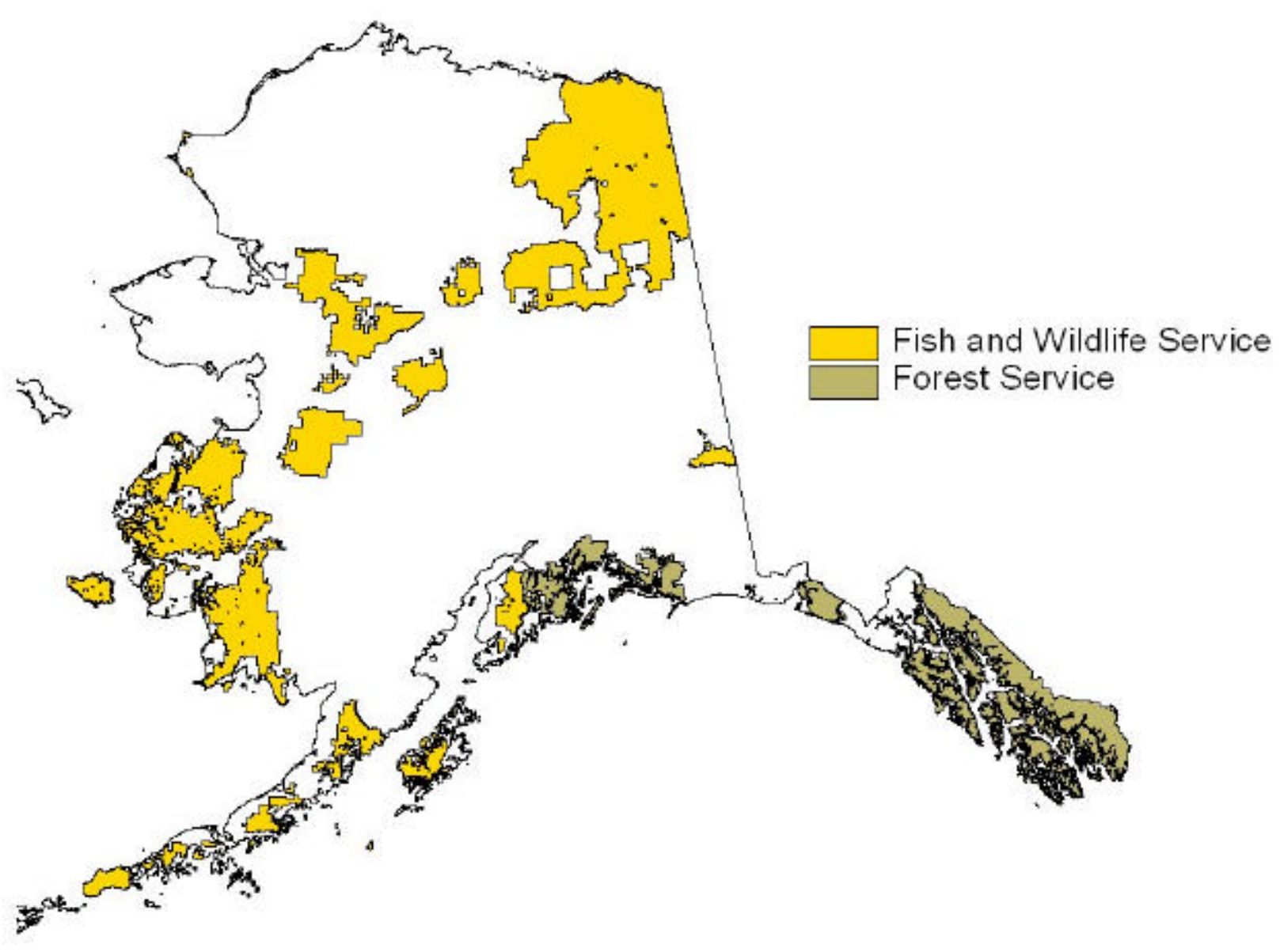




\section{Mineral-related activities:}

- BLM (public) lands are "multiple use."

Contact the respective agency to determine land use designations

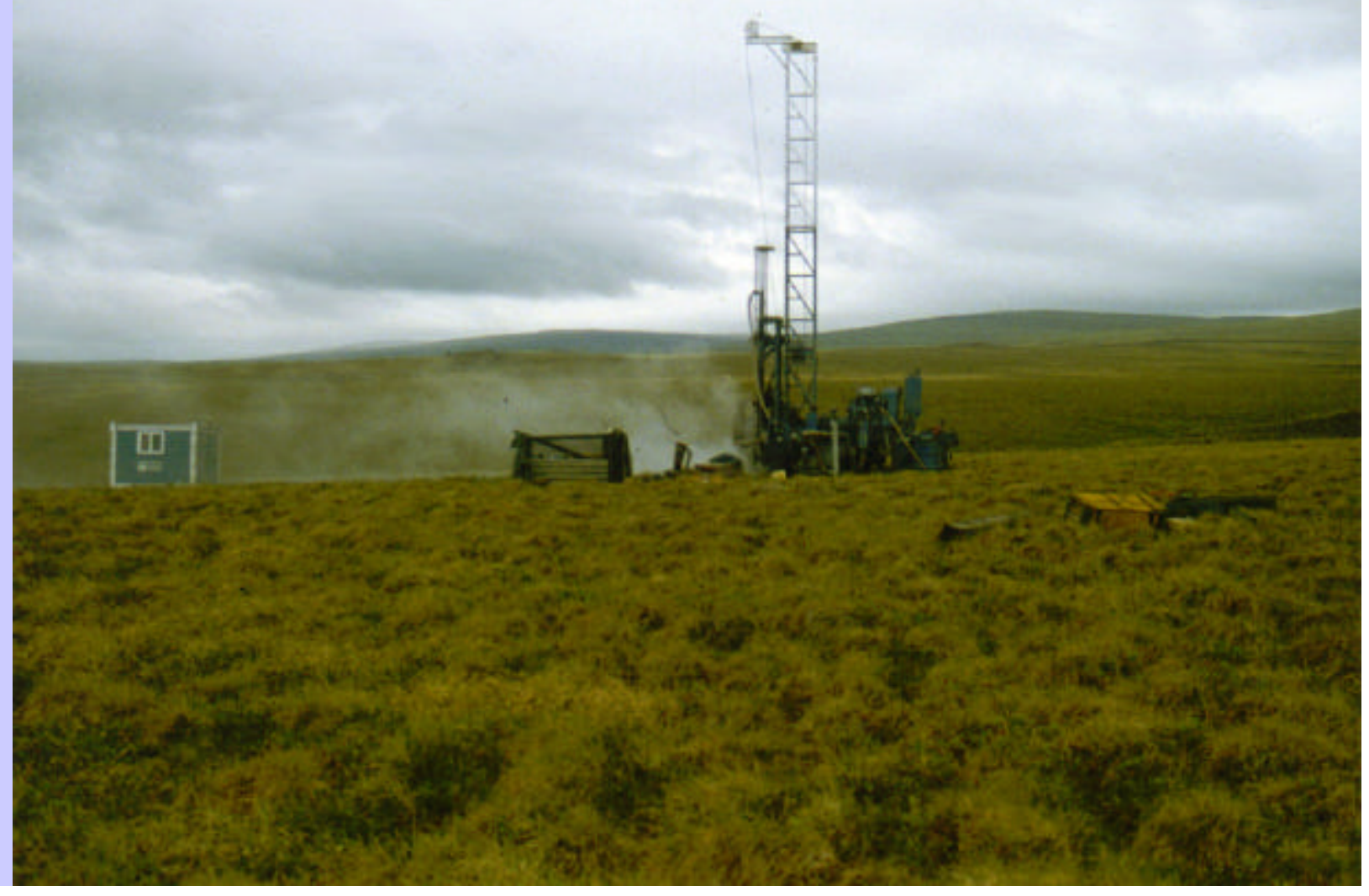




\section{Are you on BLM lands???}

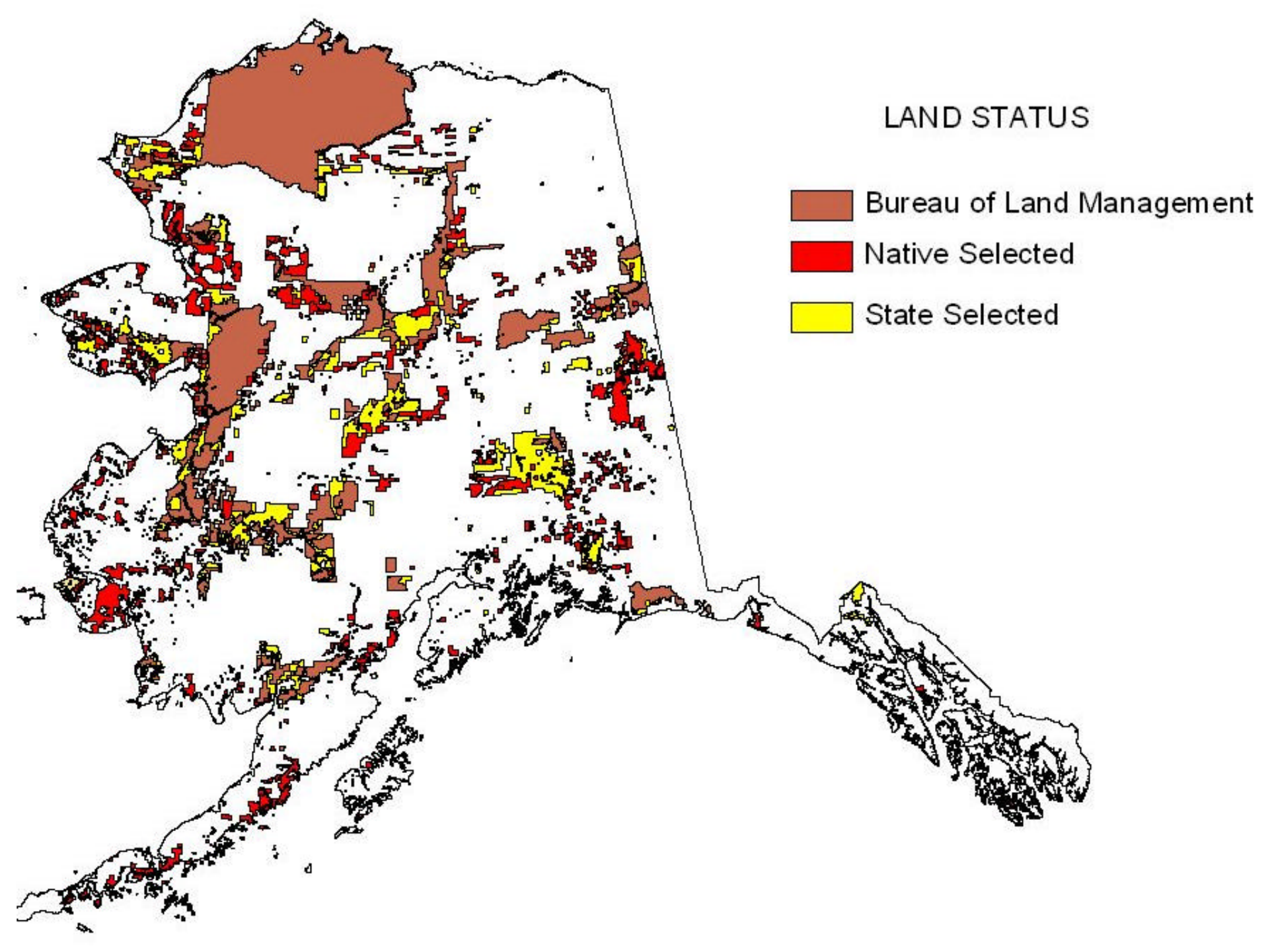


Visit the public room at the Anchorage Federal Office Building or the respective BLM field office for land status information.

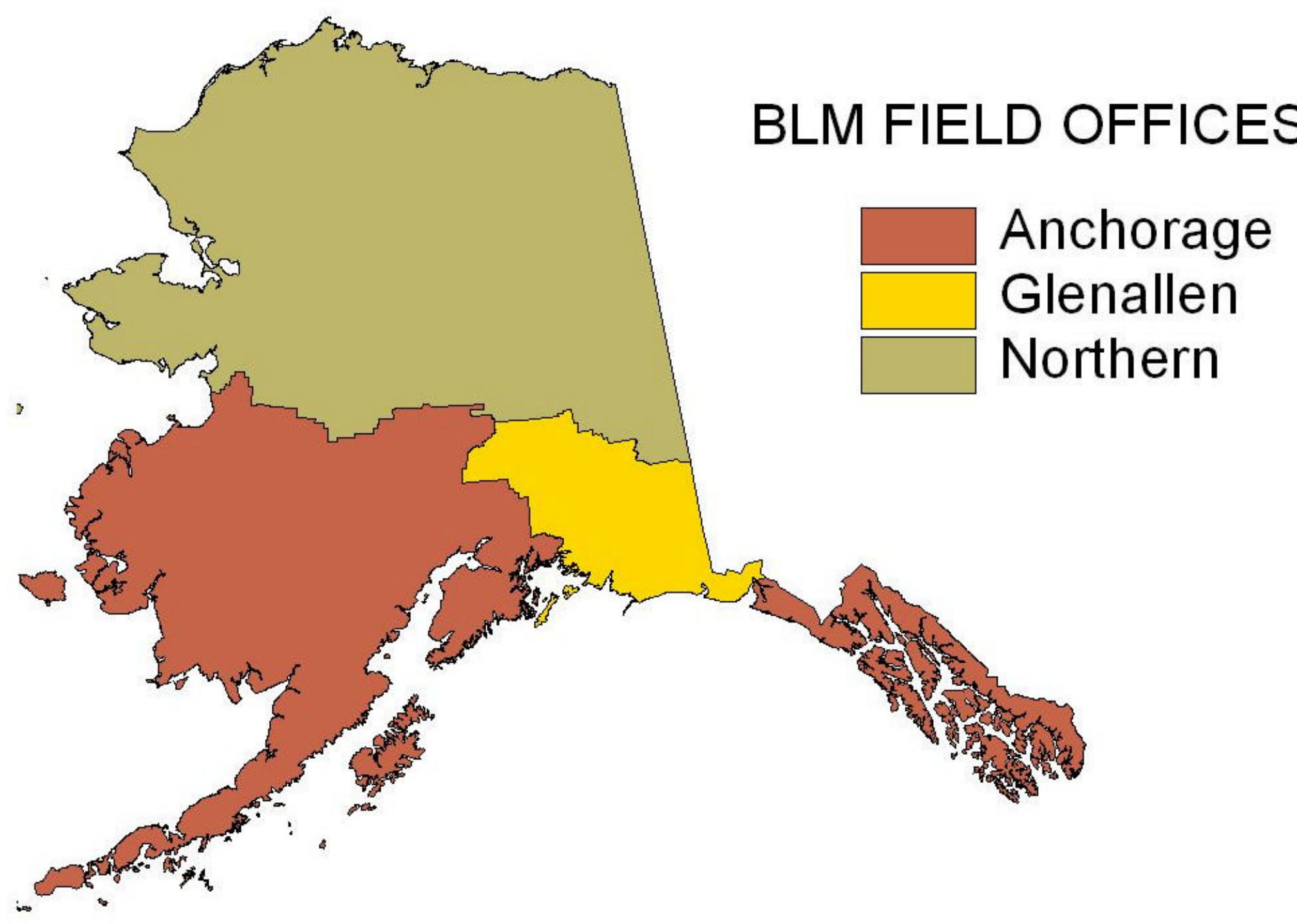




\section{GEOLOGIC RECONNAISANCE}

- This activity usually does not create surface disturbance.

- Submit a notice of your proposal to the local BLM office.

- BLM will review and may stipulate special conditions that need to be met. 


\section{GEOPHYSICAL PROFILES}

- Requires a notice to conduct geophysical exploration.

- Submit to the local BLM office for review.

- Describe the type of equipment to be used.

- Identify camp requirements.

- Address fuel storage and waste removal.

- BLM will review and make stipulations as required. 


\section{DRILLING AND CORING PROGRAM}

- Requires the issuance of a land use permit as defined under FLPMA.

- Depending on the scope of your proposal, BLM may need to do a NEPA evaluation.

- Address all aspects of your proposal - this will expedite the NEPA process.

- Submit your proposal to the local BLM office.

- BLM will issue a Right of Way (ROW) permit or a Special Use Permit (SUP).

- Submit an Application for Permit to Drill (APD). 


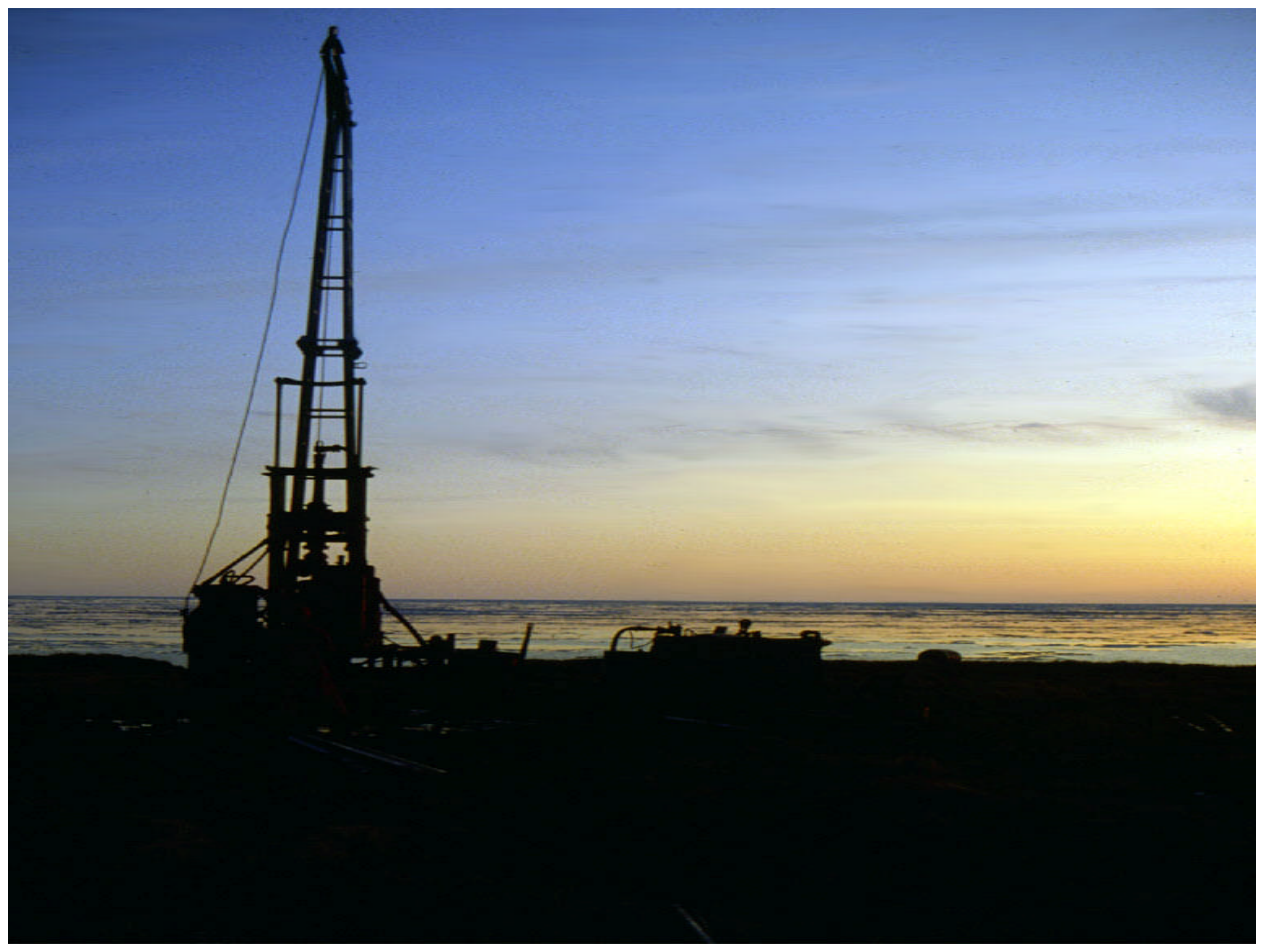




\section{Alaska Regional Native Corporation Lands}

Norm Phillips Doyon Limited

Nick Enos Calista Corporation

Teresa Imm Arctic Slope Regional Corporation

Wes Nason Ahtna Corporation

Paul Roehl Bristol Bay Native Corporation 


\section{DOYON, LIMITED}

Coalbed Methane Workshop

March 3, 2000

\section{General:}

- Supportive of Economic Development in all Alaskan villages.

- Key to economic development in rural Alaska is the cost of power and fuel for facility / home heating.

- Seasonal access requires the storage of a large quantity of diesel fuel in each village.

- Utilization of indigenous fuels is one way to reduce the costs associated with the transportation and storage of diesel fuel but community support is essential.

- 3 largest villages in the Doyon region are located in basins with peripheral coal outcrops. (McGrath, Galena and Fort Yukon).

Doyon's Role:

- Interior ANCSA lands - Doyon manages the subsurface and mineral estate.

- Promote exploration of our lands for minerals and energy resources. (\$30 million database)

- Exploration permits and development agreements.

\section{Contact:}

James Mery, Senior Vice President

Lands \& Natural Resources

Doyon, Limited

201 First Avenue, Suite 300

Fairbanks, Alaska 99701

(907) 459-2030 


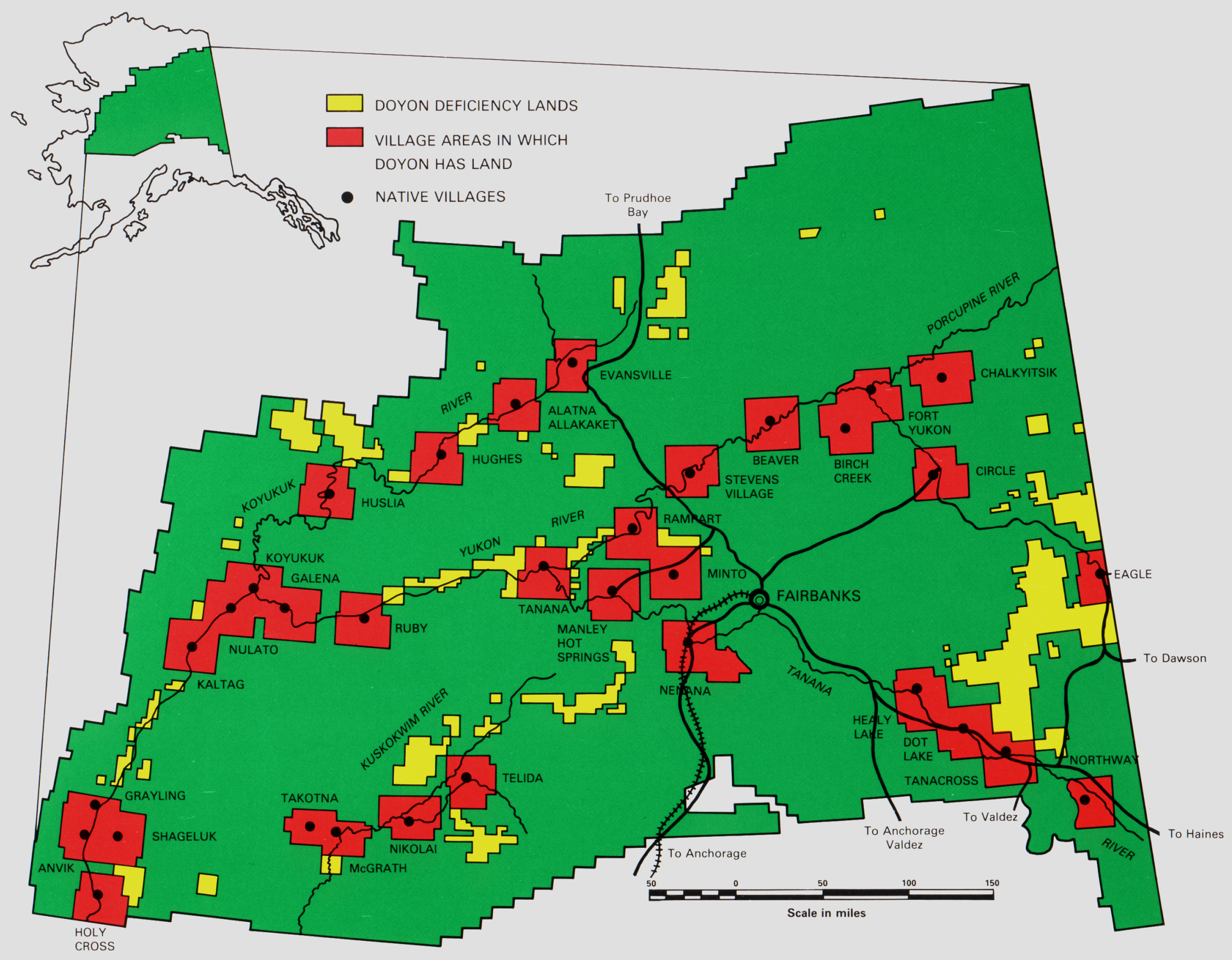




\section{Speaker Biography}

\section{Nick Enos}

Nick received a masters in geology and geophysics from Oregon State University in 1992. Since then he has worked primarily in mineral exploration, mostly in Alaska. He worked for Kenecott Exploration on the Seward Peninsula near Nome and spent a year at Kennecott's Greens Creek Mine on Admiralty Island. For the past three years Nick has been with Calista Corporation as an exploration geologist and GIS specialist. 


\section{Calista Corporation Lands: Energy Needs, Previous Hydrocarbon Exploration, and the Potential for Natural Gas}

Calista is one of 13 Alaska Regional Native Corporations, formed in 1972 after passage of the Alaska Native Claims Settlement Act (ANCSA). Located in the YukonKuskokwim Delta area of southwestern Alaska, the Calista Region encompasses 56,000 square miles containing 6.5 million acres of private land. This mostly rural region of 48 villages includes the city of Bethel, with a growing population of nearly 6000 residents. The entire region is $100 \%$ dependent on imported liquid petroleum products for diesel power generation, heating, and transportation. Bethel alone annually consumes 8 million gallons of imported fuel. Development of local energy sources, such as natural gas, is critical to stimulating economic development in the region.

The Donlin Creek Gold Project illustrates the numerous obstacles to economic development in the Calista Region. Donlin Creek is currently in the advanced stages of exploration by Placer Dome Inc. Placer Dome has outlined a gold resource of 11.4 million ounces, worth almost $\$ 3.5$ billion at today's gold price. If developed, Donlin Creek could provide 200-300 full-time jobs for at least 1 O-1 5 years. Although Donlin Creek is a world class gold resource, it is currently sub-economic. A required $50 \mathrm{Mw}$ power plant would contribute to high capital costs and operating costs for the project. Finding a nearby source of natural gas, which could supply the estimated $5 \mathrm{BCF} /$ year, would be an obvious benefit to Donlin's economic viability. The lack of energy and transportation infrastructure in the region is the greatest economic barrier to any potential resource development.

Previous hydrocarbon exploration in the Calista Region has focused primarily on the conventional petroleum potential of the Bethel Basin, Yukon Delta, and Holitna Basin. The Bethel and Holitna basins are Cenozoic non-marine basins. The Yukon Delta is a large, modem, deltaic complex adjacent to Norton Basin. Industry interest in these areas has been low due to the lack of evidence for a thick Tertiary section, as well as poor source-rock/reservoir-rock potential. However, opportunity exists for discovery and development of shallow biogenic and thermogenic natural gas sources. 


\title{
CALISTA CORPORATION LANDS \\ Energy Needs, Previous Hydrocarbon Exploration, and the Potential for Natural Gas
}

\author{
Nick Enos
}

Calista Corporation, Dept of Land and Natural Resources Opportunities in Coalbed Methane Conference, March 3, 2000 


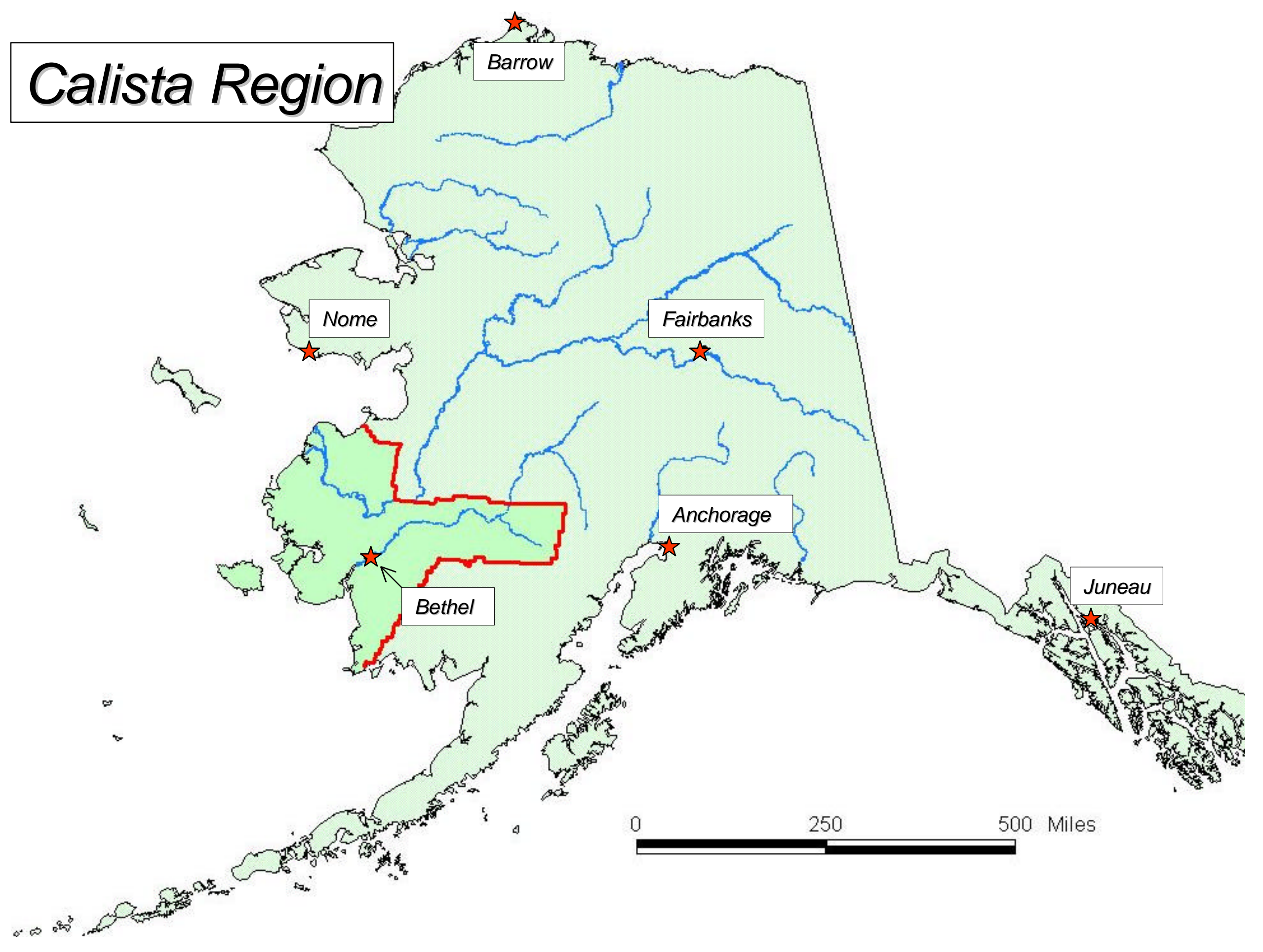




\title{
Calista Corporation Lands: Energy Needs, Previous Hydrocarbon Exploration, and the Potential for Natural Gas
}

Nick Enos - Calista Corporation

Opportunities in Alaska Coalbed Methane Conference, Anchorage, March l-3, 2000

\begin{abstract}
Calista is one of 13 Alaska Regional Native Corporations, formed in 1972 after passage of the Alaska Native Claims Settlement Act (ANCSA). Located in the Yukon-Kuskokwim Delta area of southwestern Alaska, the Calista Region encompasses 56,000 square miles containing 6.5 million acres of private land. This mostly rural region of 48 villages includes the city of Bethel, with a growing population of nearly 6000 residents. The entire region is $100 \%$ dependent on imported liquid petroleum products for diesel power generation, heating, and transportation. Bethel alone annually consumes 8 million gallons of imported fuel. Development of local energy sources, such as natural gas, is critical to stimulating economic development in the region.

The Donlin Creek Gold Project illustrates the numerous obstacles to economic development in the Calista Region. Donlin Creek is currently in the advanced stages of exploration by Placer Dome Inc. Placer Dome has outlined a gold resource of 11.4 million ounces, worth almost $\$ 3.5$ billion at today's gold price. If developed, Donlin Creek could provide 200-300 full-time jobs for at least 10-I 5 years. Although Donlin Creek is a world class gold resource, it is currently sub-economic. A required $50 \mathrm{Mw}$ power plant would contribute to high capital costs and operating costs for the project. Finding a nearby source of natural gas, which could supply the estimated 5 BCF/year, would be an obvious benefit to Donlin's economic viability. The lack of energy and transportation infrastructure in the region is the greatest economic barrier to any potential resource development.

Previous hydrocarbon exploration in the Calista Region has focused primarily on the conventional petroleum potential of the Bethel Basin, Yukon Delta, and Holitna Basin. The Bethel and Holitna basins are Cenozoic non-marine basins. Yukon Delta is a large, modern, deltaic complex adjacent to Norton Basin. Industry interest in these areas has been low due to the lack of evidence for a thick Tertiary section, as well as poor source-rock/reservoir-rock potential. However, opportunity exists for discovery and development of shallow natural gas sources.
\end{abstract}




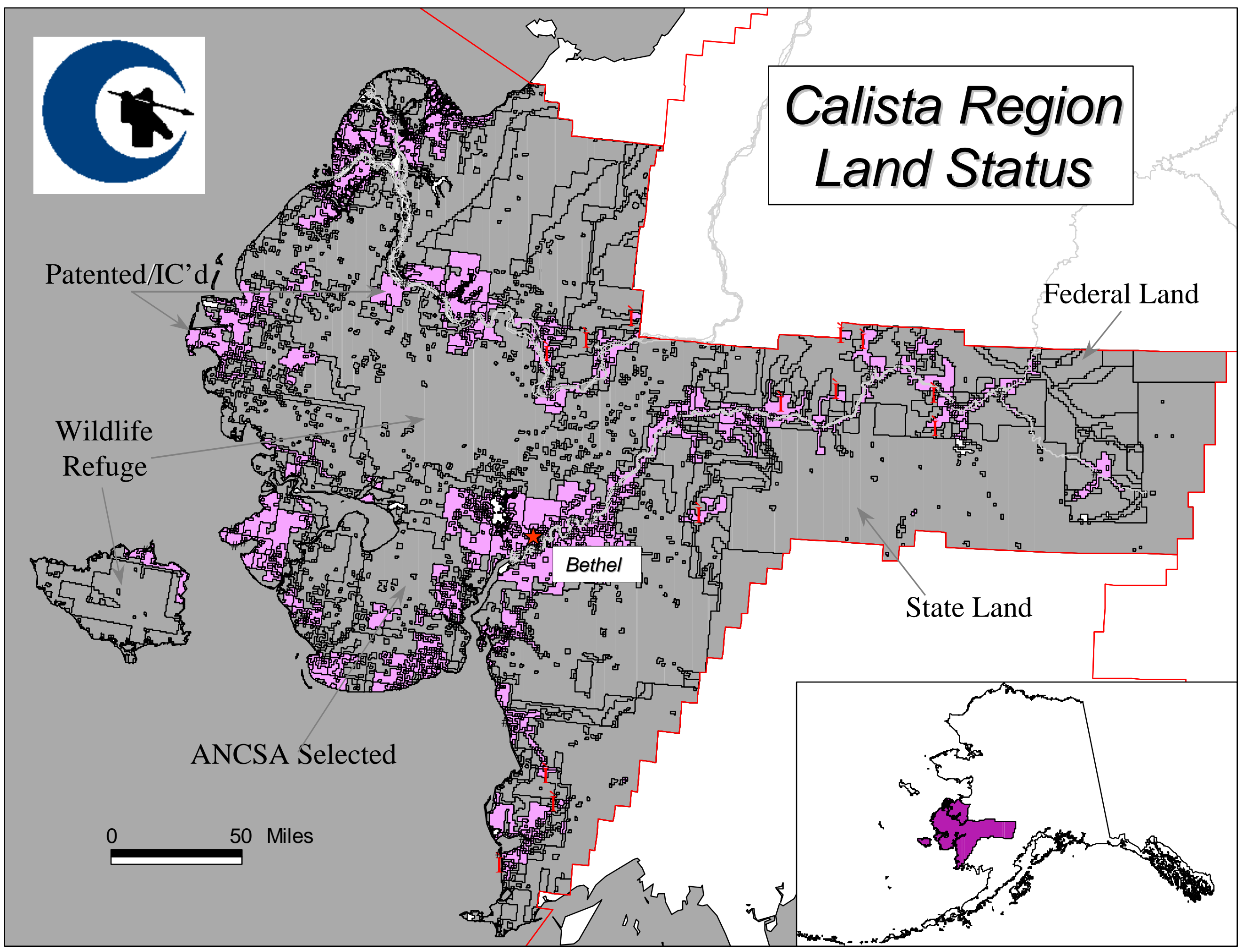




\section{Calista Region: Land}

-56,000 square mile area

- 6.5 million acres of ANCSA land entitlement

- Surface Selections by Local Village Corporation

- Calista Sub-Surface/Mineral Ownership 


\section{Calista Region: Profile}

- 27,000 Residents (Mostly Yup'ik and Athabaskan)

- $85 \%$ Native Workforce is Unemployed

- Mean Average Income in Region=\$8,500/year

- No Roads Linking Region to Outside 


\section{Calista Region: Energy}

- 100\% Dependent on Imported Liquid Fuel

- Bethel Consumes 8 million gallons/year; 3 million gallons/year to power generation

->20 million gallons consumed delta-wide

- Average energy cost $\sim \$ 0.30-\$ 0.60 / \mathrm{kWh}$ without PCE subsidy vs. \$0.09/kWh in Anchorage 


\section{Donlin Creek Project}

\section{-11.4 Million Ounces Gold}

-\$3.5 Billion of Contained Gold

-Alaska's Largest Au Resource

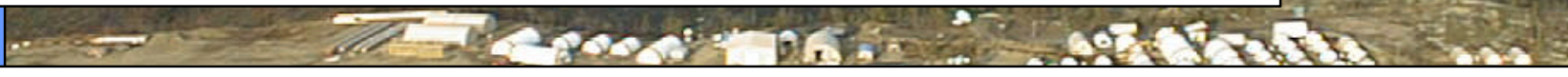
- Could Provide 300 Jobs for 10+ Years

\section{-SUB-ECONOMIC!}




\section{Donlin Creek Project}

- Will Require 50 MW Power Plant

- Will Consume 10 Million Gallons of Diesel/year

- Hundreds of Fuel Barges/year

- Alternative Fuels? (Gas, Coal...) 


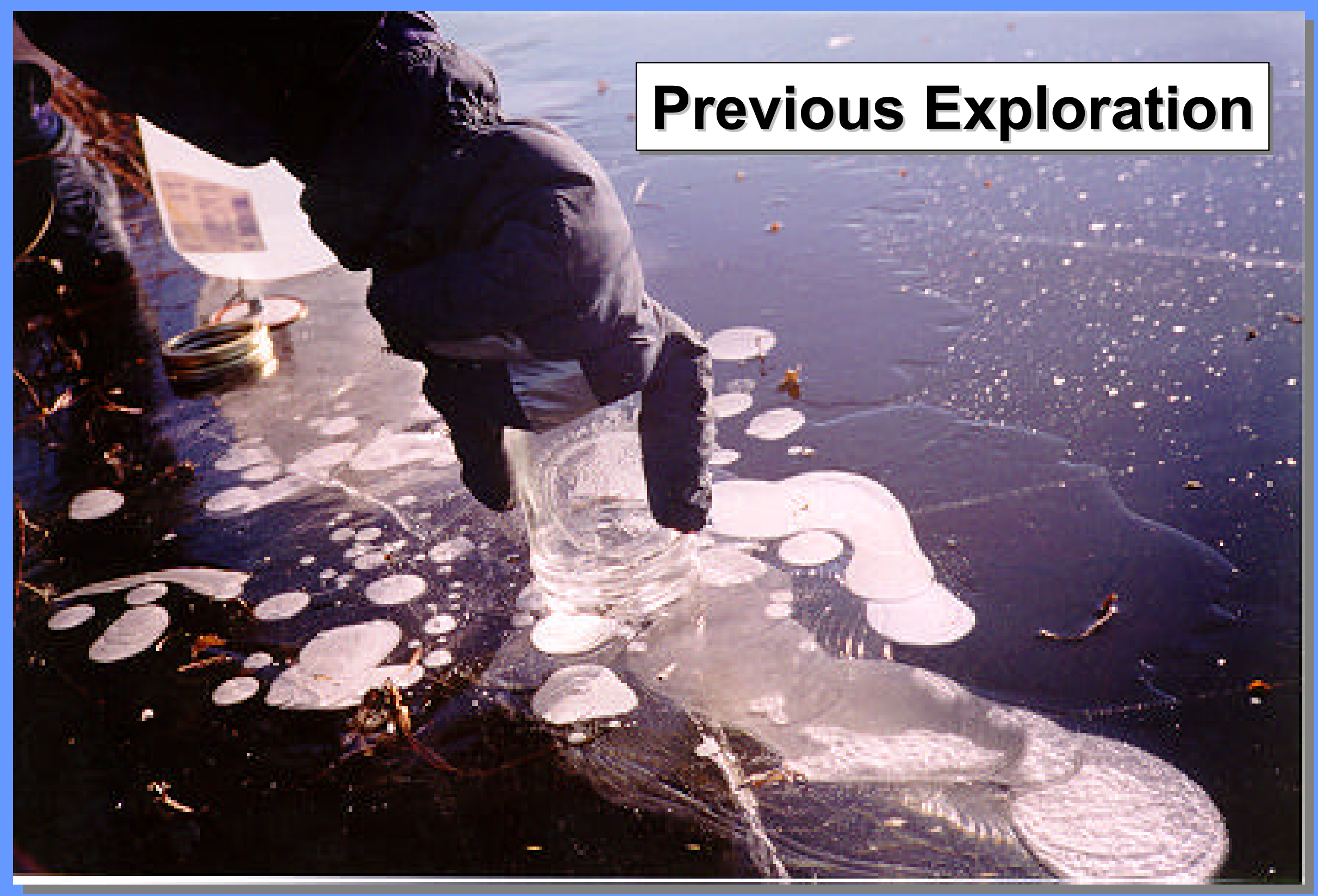




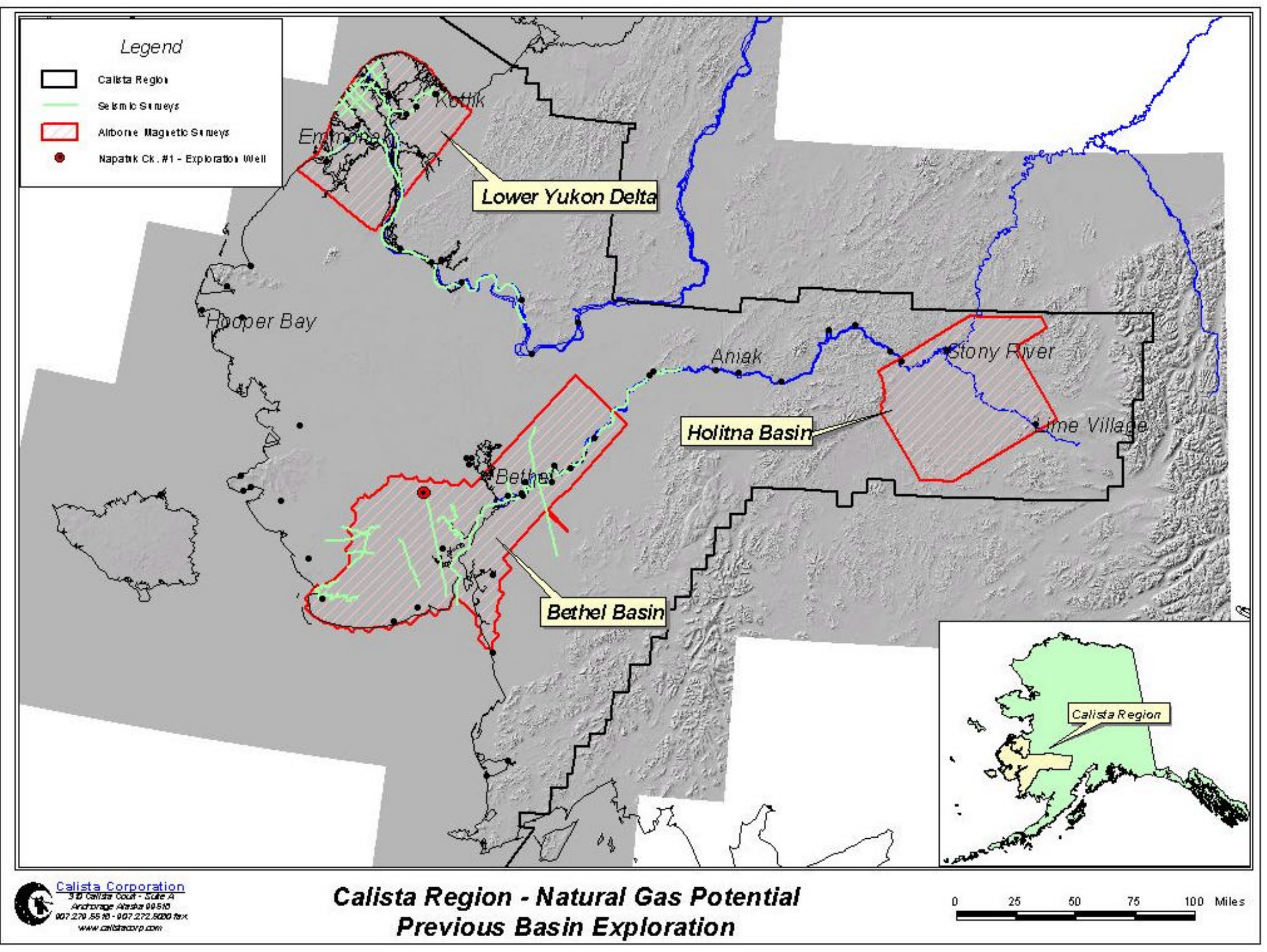




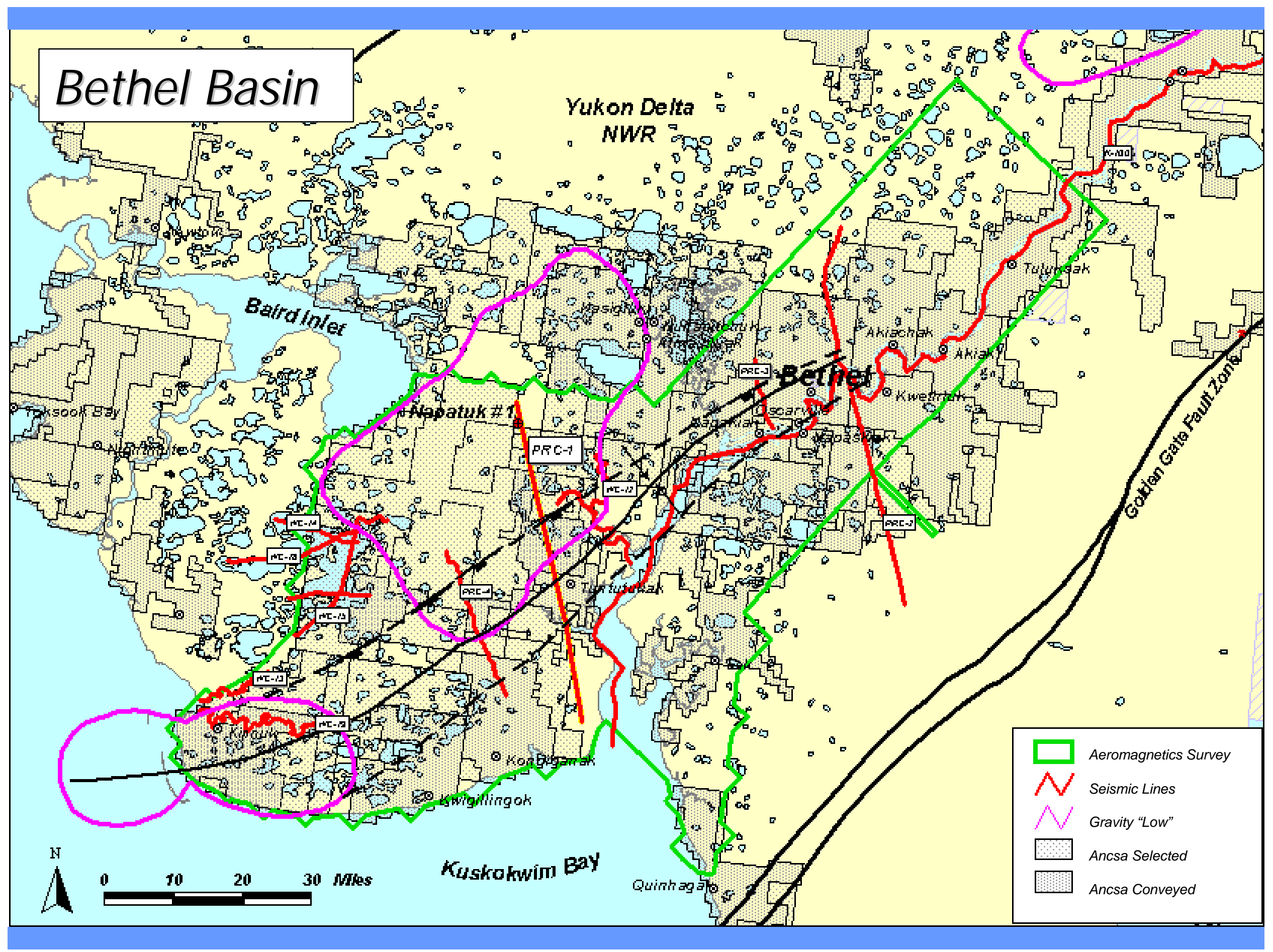




\section{Bethel Basin}

- Cenozoic non-marine basin

- 1961 Pan-American's Napatuk Ck.\#1 drilled to 14,890' on gravity "low"; only 2000' Tertiary section encountered; Cretaceous is overmature below 5100'

- Cretaceous Kuskokwim Group flysch has poor source/reservoir rock characteristics

-Seismic acquired in 1974-75 show Tertiary section thickens to over 7500 ' south of well

- Potential for natural gas in Tertiary? 


\section{PRC-1 Seismic Line}

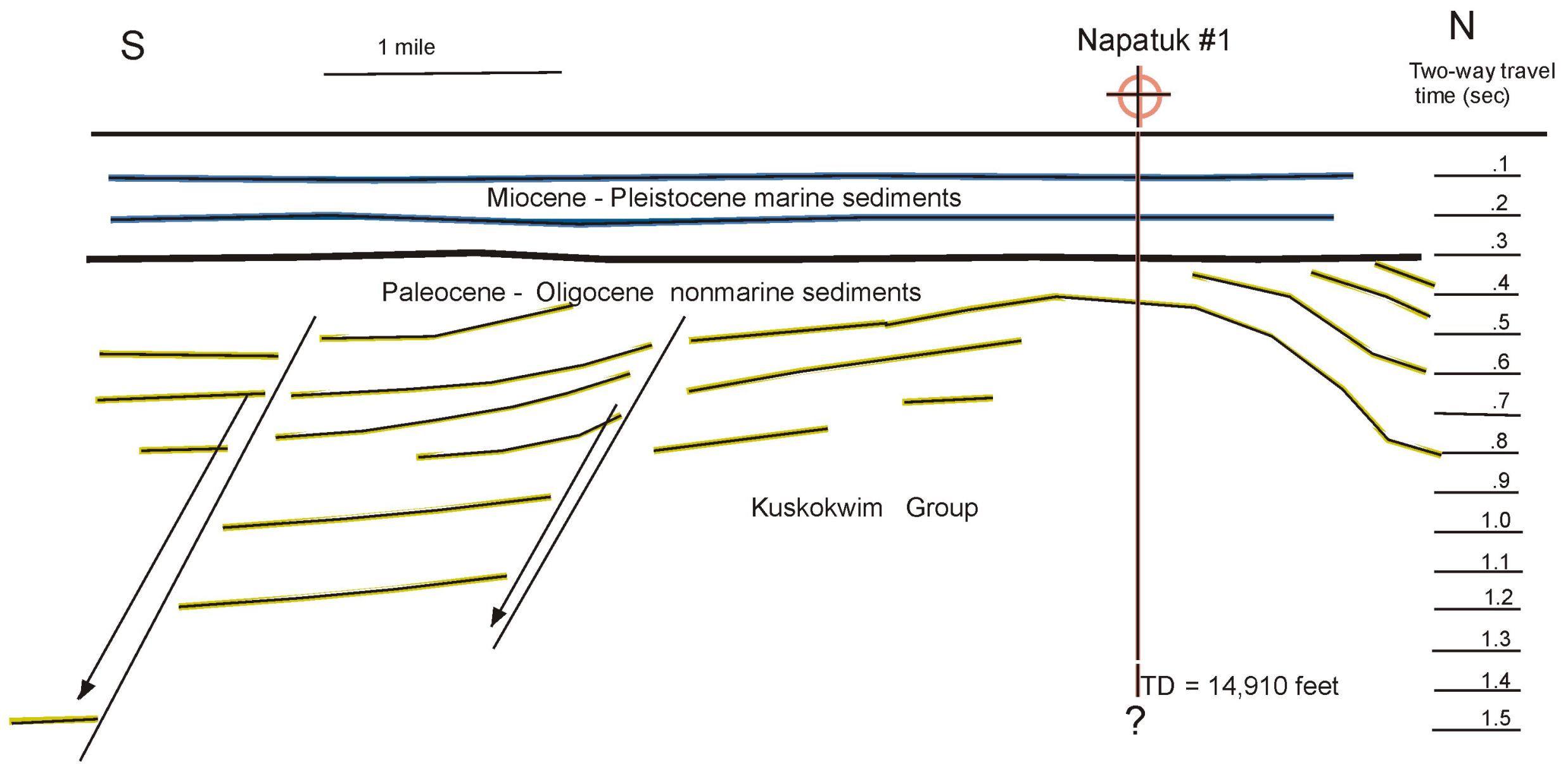

Seismic Reflection Sketch from Line PRC-1 


\section{Yukon Delta}

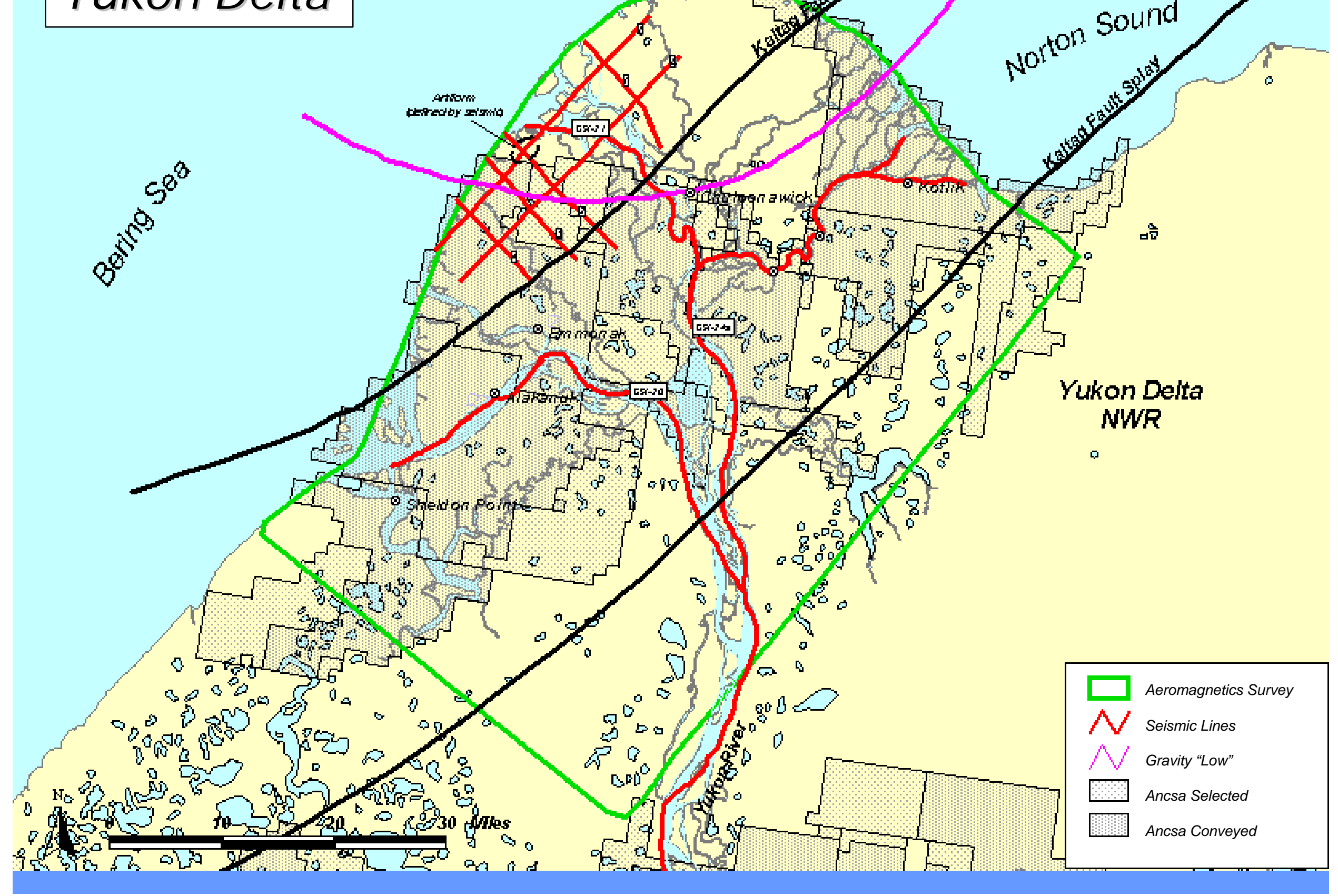




\section{Yukon Delta}

- Modern delta complex adjacent to Norton Basin

- Norton Basin contains estimated 2.7 TCF conventionally recoverable natural gas in Tertiary

- Gravity and 2-D seismic (1981) indicate 5000' Tertiary section beneath delta

- Antiformal target identified by Amoco but never drilled

- Potential for shallow biogenic gas? 


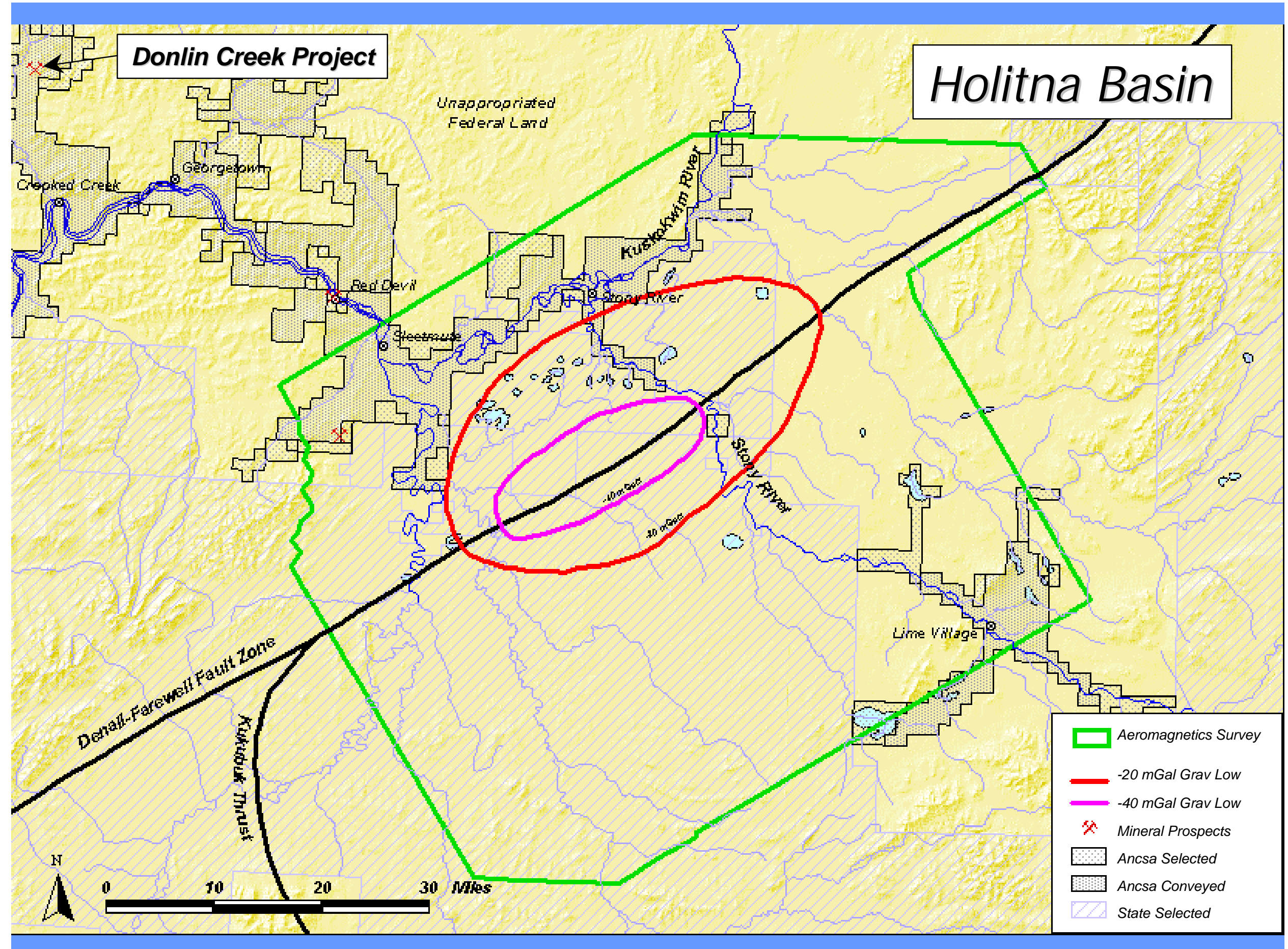




\section{Holitna Basin}

- Small, deep, Cenozoic tectonic basin along Denali-Farewell Fault Zone

- -40 mGal gravity low indicates 10,000 '-14,000' of Cenozoic fill

- DGGS source-rock sampling (1998) indicates low (TOC) contents; Low volume of Type III and IV Kerogens

- Tertiary coal-bearing strata outcrops along the Farewell Fault Zone (Cheeneetnuk River, Windy Fork)

- Potential for coalbed methane/biogenic gas remains untested 


\section{Coal Occurrences}

\section{Nelson/Nunivak Islands}

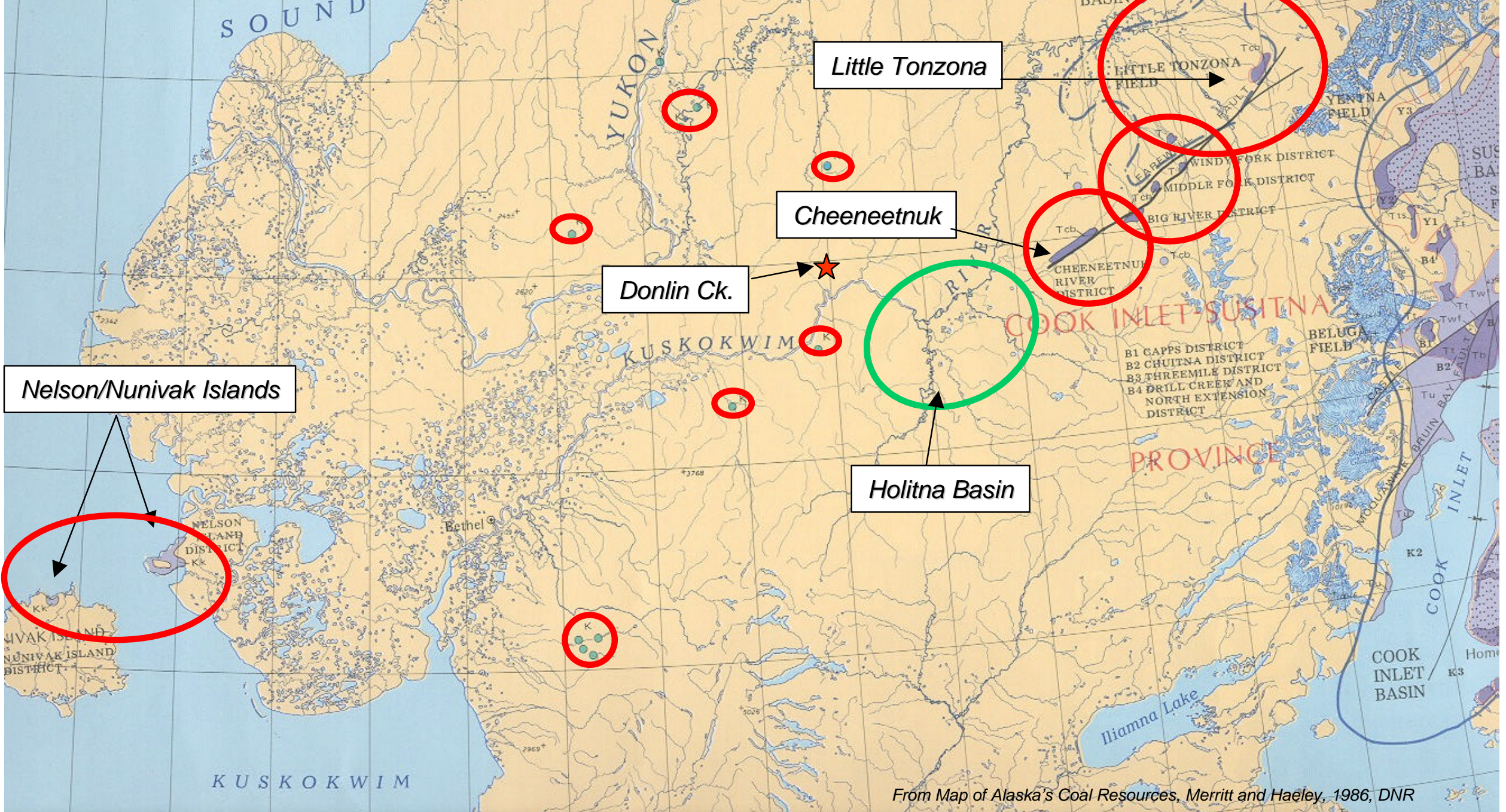



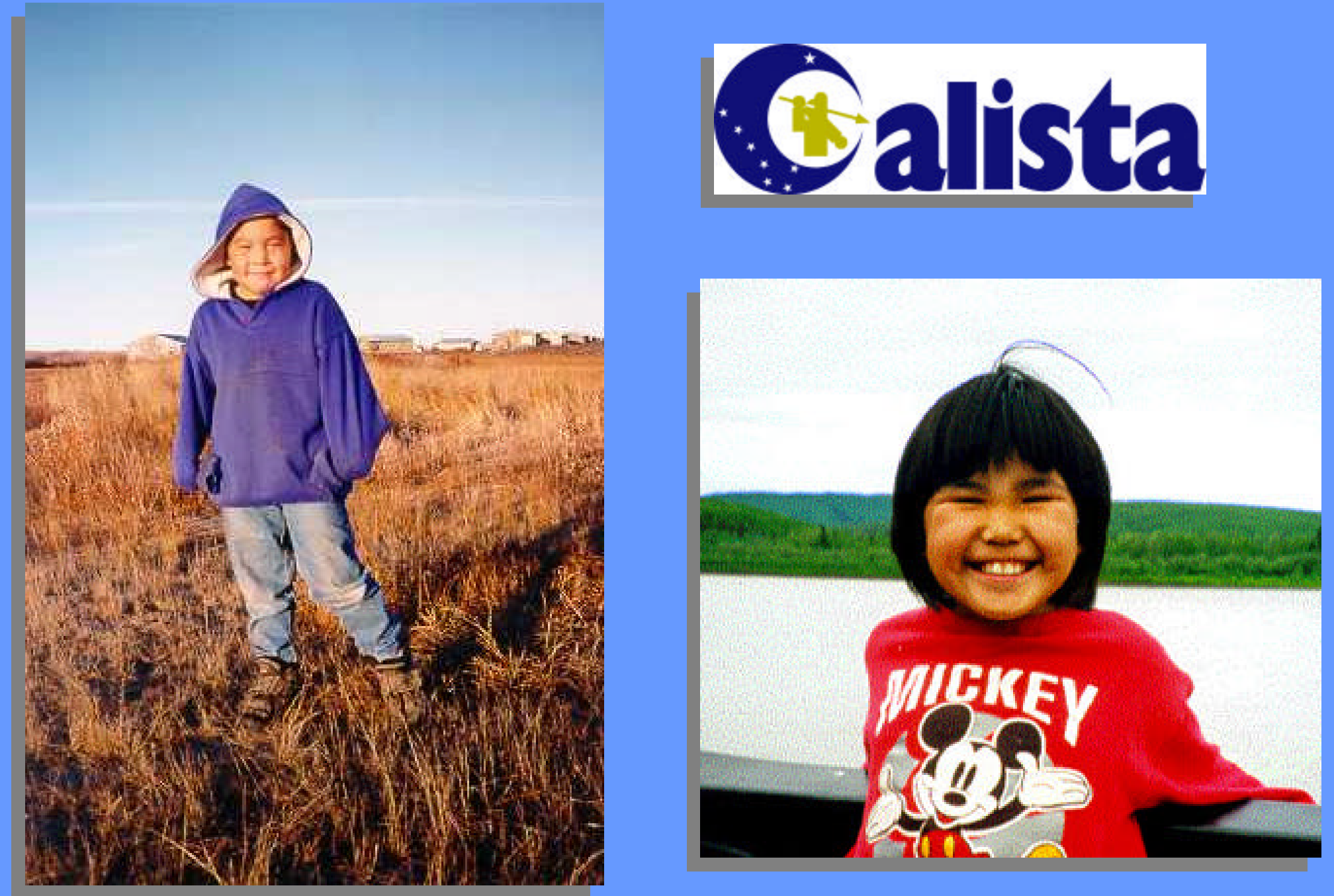


\section{BRISTOL BAY NATIVE CORPORATION}

\section{Land Ownership}

One of twelve regional corporations in Alaska, the Bristol Bay Native Corporation (BBNC) was formed in 1971 pursuant to the Alaska Native Claims Settlement Act (ANCSA). BBNC received a land entitlement of 3.1 million acres of land, chosen mostly for its mineral, oil and gas potential wherein it controls the entire subsurface estate. The surface estate of these lands is usually controlled by the 30 village corporations located in the region. BBNC will also own about 120,000 acres of fee-simple land which includes both surface and subsurface rights under a special classification of ANSCA. In contrast to many of Alaska's regional corporations, BBNC has received $90 \%$ of its entitlement as interim-conveyances (IC's), about two-thirds of which has already been patented. The remaining IC'd lands have met all requirements of a patent except for the final land survey and are leaseable to third parties.

\section{Land Policy}

BBNC's Board of Directors have adopted a liberal mineral exploration policy. Most of BBNC's land is under explored, and BBNC openly encourages mining company interest. BBNC's Land Department is knowledgeable of the people, village policy, infrastructure and logistics and can help support new mining company interest.

If you would like more information on BBNC and its resources, try our Web Page:

www.touchngo.com/bbnc

or contact Jack Moores or Paul Roehl of the Land Department:

Bristol Bay Native Corporation

800 Cordova St.

Anchorage, AK, 99501 


\section{Ahtna Regional Hydrocarbon Potential}

Central Alaska:

Copper River Basin

1/29/2001 


\section{Basin Overview Summary}

- 32 holes drilled: 1952 - 1994

- Basin contains coal beds

- Basis has road/trail access

- Exploration License decision pending 


\section{Most Recent Activity}

1980: Ahtna/Amoco drilled three targets

1994: ARCO concluded Wrangell Orogeny cooked the rocks

1999: Anchutz applied for Exploration License 


\section{Attention Getters}

1971: Water well flowed $67 \%$ CH4 and $32 \% \mathrm{~N} 2$ at $680 \mathrm{~K}$ cfd from depth of 160 feet.

- Mud volcanoes in the region produce $\mathrm{CO} 2$. 


\section{Current Status}

2000: State DNR best interest finding on Exploration License Area

2001: Possible drilling. 


\section{Ahtna Wants Holes in the}

\section{Ground}

- Ahtna is encouraging gas exploration in the region.

- Ahtna can provide proprietary information on past drilling and geologic studies. 


\section{Challenges}

- The region has a small population.

- Copper Center, National Park Visitor Center, Glennallen area is best potential market. 


\section{Opportunities}

- Ahtna Minerals may provide some funding for shallow gas exploration. 


\section{Pre-Conditions for Success}

- Respect for the local environment.

- Respect for the local culture.

- Eliminating impacts on subsistence hunting and fishing. 


\section{Action Plan}

- Ahtna supports Anschutz' exploration license application.

- Ahtna is looking for partners to explore on selections and conveyed lands.

- Ahtna is considering self-funding a low budget exploration effort. 


\section{Luncheon}

\section{Joe Green}

Representative - Alaska State Legislature 


\title{
Speaker Biography
}

\author{
Joe Green
}

Representative Joe Green

District 10 - Republican

Elected to the House

$1980,1982,1984,1986$

COMMITTEE MEMBERSHIP \& LEADERSHIP POSITIONS

House Majority Leader

Vice-Chair: House Judiciary

Member: House Committee on

Committees; Health, Education \& Social Services; House Rules; House Special

Committee on Utility Restructuring (alternate for Speaker Porter); House Special

Committee on World Trade \& State/Federal Relations; Senate Finance; Legislative Budget \& Audit: House State Affairs: House Special Committee on Oil \& Gas

Legislative Session Contact:

State Capitol, Room 214

Juneau, AK 99801-1 182

907-465-493 1

800-870-493 1

fax: (907)465-4316 email: Representative Joe Green@,legis.state.ak.us

Interim Contact:

$716 \mathrm{~W}$ 4th Suite 350

Anchorage, AK 99501-2133

907-269-0123

fax: (907) 269-0124

Education:

University of Missouri at Rolla, 1951-55, B.S. Petroleum Engineering Post

Graduate - University of Southern California, 1962-63, 19 law credits 
Political and Government Positions:

Manager, Reservoir Engineering, AOGCC; Director, Minerals \& Energy

Management, ADNR; Petroleum Administrator, Santa Barbara County, CA; Senior Engineer, California State Lands Commission

Business and Professional Positions:

Engineer/Exploration Permit Coordinator, ARCO, Inc. (retired 1992); Engineer:

Chevron Oil Company (California), Cities Service Oil Company

(Oklahoma/Texas)

Service Organization(s) Membership:

Society of Petroleum Engineers; Elks Club; Little League, Boy Scouts of America; Ushering in the Arts; Toastmasters International; Elder, First Presbyterian Church Miscellaneous:

General Chairman: Arctic International Technology Conference, Anchorage, 199 1; Meeting Planner of the Year, Anchorage Visitors \& Convention Bureau, 1990 


\section{Panel Sessions: Advances in Exploration Methods}


Conventional Traps and Seals as Critical Elements in the Preservation of Shallow Coalbed Methane Prospects Within Rocky Mountain Foreland and Laramide Basins

Charles E. Barker U.S. Geological Survey 


\section{Speaker Biography}

\section{Dr. Charles E. Barker}

1. Education: San Diego State University (B.S., 1974), University of California, Riverside (M.S., 1979) and the University of Adelaide (Ph.D., 1995).

2. Expertise: 18 years experience with a research emphasis on using multiple thermal indicators to constrain thermal history for basin modeling of petroleum generation. Expertise in kerogen and coal petrology, Geochemical source rock and coal evaluation; fluid inclusion geothermometry and petrography; Computer basin modeling in 1D and 2D. Coal core desorption and gas in place assessment..

3. Background: Dr. Charles E. Barker is a Senior Research Geologist with the central region Energy Resources Team . He has prior experience with Tenneco and Union Oil Companies. Currently, President-elect of the Society for Organic Petrology, Second Chairperson of the Coal Geology Division of the Geological Society of America and Past President of the Society for Luminescent Microscopy and Spectroscopy. He has also acted as Chairman of the USGS Energy Resources Team Current Project Review committee, Member of the USGS Energy Resources Team Program Council, and as a Member of SEPM Education Committee. He is a co-editor of a volume on thermal maturation in energy exploration, as well as short course volumes on luminescence microscopy and on the Geology of Coal bed gas. Foreign assignments include burial and paleotemperature studies in the Gippsland Basin, Australia, and Sava Depression, Croatia. Coal bed gas studies in Armenia, Croatia and Colombia.

4. Current Research: A) the geologic factors active in the retention of coal bed gas; B) methods of assessing coalbed gas in place; C) geothermometry using vitrinite reflectance and reequilibrated fluid inclusions; and D) detection and correction of vitrinite reflectance suppression using hydrous pyrolysis tight gas reservoirs in the Piceance and Green River basins, and a coal bed gas study in the Wind River Basin. 


\section{Conventional Traps and Seals as Critical Elements in the Preservation of Shallow Coalbed Methane Prospects.}

\section{Charles E. Barker, U.S. Geological Survey, Box 25046, MS 977, Denver, CO 80225 USA (303) 236-5797 voice; (303) 236-3202 fax; email: barker@usgs.gov}

Langmuir theory of gas adsorption indicates that coalbed methane (CBM) is retained in coals mostly by hydraulic pressure rather than by conventional traps and seals. However, drilling of shallow prospects shows that preservation is more complex than simple pressure holding gas in place. This complexity is illustrated by several examples from Rocky Mountain Basins.

In the Uinta basin, the coal-bearing Ferron Sandstone member of the Mancos Shale was deposited in two adjacent, deltaic depo-centers that built out from the western shoreline of the Cretaceous-age seaway. The southern Ferron coals were deposited in the Last Chance Delta which lies mainly to the southeast and southwest of Emery, Utah. The northern Ferron coals were deposited in the Vernal delta that extends from near Ferron, Utah to the north of Price, Utah. In the northern Ferron CBM fairway, commercial production of CBM is related to an eastward updip pinch-out of the coals into a marine mudstone along the western flank of the San Rafael Swell. East and southeast of Emery, Utah, the southern Ferron coals are exhumed updip and this gas trap is breached. No commercial CBM has been found here, even though the southern Ferron coals, west of Emery, Utah, are still buried at depths comparable to those of the northern Ferron coals and are isolated from the outcrop to the east by block faulting. The southern Ferron coals west of Emery, however, have only been tested for CBM by wells near the Joe's Valley fault zone where meteoric recharge may have locally stripped the coals of methane. meteoric recharge into the Upper Ferron Sandstone related to the Tertiary Joes Valley fault system that cuts the production fairway starting from near Emery and continuing to the south. This recharge has reduced dissolved solids in the groundwater from over 6,000 ppm to $7.50 \mathrm{ppm}$ in the Upper Ferron Sandstone. A reason for the lowered gas contents may be that fresher water recharge introduced into the coalbeds by Miocene age faults that cross the southern Ferron CBM fairway to the west of Emery, Utah, are removing gas in solution. Coals are commonly aquifers that can transmit large amounts of fluid. Fresher water has an increased solubility of methane compared to more saline fluids. We conjecture that as fresher water recharge flows through the coal beds that the enhanced solubility of methane in these fluids is capable of stripping sorbed methane from the coal over geologic time. Discharge of the methane-charged fluid would migrate the methane out of the Southern Fen-on coalbeds. In the past, when both the Northern and Southern Ferron coals were sealed by pinch-out to the east, the gas from the southern coals may have migrated north possibly contributing to the high gas contents there. Alternately, the fresher water recharge may introduce aerobic bacteria that metabolizes the methane. 
Local disruption of the seals by the faults may also be influential. In

arid times the reduced recharge and water table lowering may have naturally dewatered or lowered water pressure acting on the coals causing gas to desorb.

Internal sealing by ash beds in Fen-on coals appears to be commonly associated with volcanic air-fall ashes introduced into the coal swamp also documented. Ash beds deposited in the coal swamp, almost immediately form aquitards or seals as shown by their influence on plant debris preservation. During burial, these ash beds seemingly remain effective internal seals and in some cases gas contents may be enhanced below ash beds.

In the Wind River Basin, Cretaceous Mesaverde and Meeteetse Formation Coals were deformed and exhumed in the Latest Cretaceous and Early Tertiary. Later reburial in the mid-Tertiary allowed the trapping of biogenic gas generated after a Tertiary cover was deposited over the eroded Cretaceous rocks. Additional thermogenic gas also apparently migrated into these coalsfrom the deeper portions of the basin were thermal maturation was still ongoing during the mid-Tertiary. This biogenic and thermogenic gas is now preserved by the unconformity seal formed by the Tertiary rocks. Desorption of coal cores cut in wells spread across the Wind River Basin shows that everywhere the coals are still overlain by the later Tertiary sedimentary cover, the coals contain appreciable gas. Where the coals are uncovered but still buried at depths to 700 feet they contain little or no gas.

Stratigraphic and structural traps are important in the San Juan Basin, Black Warrior and Powder River Basins. In these basins, local antiforms formed both during compaction and later structural deformation are gas-rich compared to adjacent coals. 


\section{Shallow Gas Exploration for Red Dog Mine Gas Based Power Generation}

John Kelafant

Advanced Resources International

Scott Reeves (speaker)

Advanced Resources International 


\section{Speaker Biography}

\section{Scott R. Reeves}

Scott R. Reeves is the Executive Vice President of Advanced Resources International, Inc. in Houston where he provides reservoir engineering and other technical support to numerous international clients, and manages E \& P Research projects for the U.S. Department of Energy, the Gas Research Institute, and others. He also is consultant to the United Nations. Mr. Reeves has authored over 50 technical papers in the areas of coalbed methane, gas shales, tights sands, gas storage, and EOR. He holds a BS degree in petroleum engineering from Texas A\&M University and an MBA from Duke University. 


\section{Shallow Gas Exploration for Red Dog Mine Gas-Based Power Generation}

Cominco's Red Dog Mine in northwest Alaska is the world's largest producer of zinc concentrate. Power for the mine is currently supplied through diesel-fired generators. Electricity costs at the mine are high due to transportation costs associated with delivering diesel fuel to the mine site. In 1997, Cominco initiated a program to look at potential gas resources in the vicinity of Red Dog to serve as a lower cost fuel supply.

Based on anecdotal reports such as gas bubbles emanating from diamond drill holes, the organic-rich Ikulukrok shale quickly became the focus of the exploration program. In the lower-48 states, organic-rich shales have been significant gas producing reservoirs in the Michigan, Ft. Worth, and Appalachian basins. To date, 55 core samples of the Ikulukrok shale have been taken at Red Dog and measured for gas content. Ikulukrok gas content values are comparable to those in productive gas shale basins, ranging from 30 to $65 \mathrm{cf} /$ ton. Gas composition analyses show the gas to be $99 \%$ methane, with no $\mathrm{H} 2 \mathrm{~S}$ or $\mathrm{CO} 2$ detected.

The exploration program to date has demonstrated that a significant gas resource exists at Red Dog, enough to supply Red Dog's current power demands for over 500 years. However, the ability to turn this gas resource into a producible reserve will require the presence of adequate permeability in the shale. Obtaining accurate permeability measurements in the Ikulukrok shale will be the focus of the next stage in the Red Dog gas shale exploration program 


\title{
SHALE GAS EXPLORATION AT THE RED DOG MINE, ALASKA
}

Opportunities in Alaskan Coalbed Methane

\author{
Sponsored by: \\ West Coast PTTC \\ Anchorage, Alaska \\ Presented by: \\ Scott R. Reeves \\ Advanced Resources International \\ March 3, 2000
}




\section{Gas Shale Production}

Gas shale production reached 346 Bcf in

1998, a three-fold increase since 1988. The bulk of the production has been from Antrim Shale and Devonian Appalachian Shales. Increasing production is seen from the Barnett and Lewis Shales. 


\section{U.S. Gas Shale Basins}

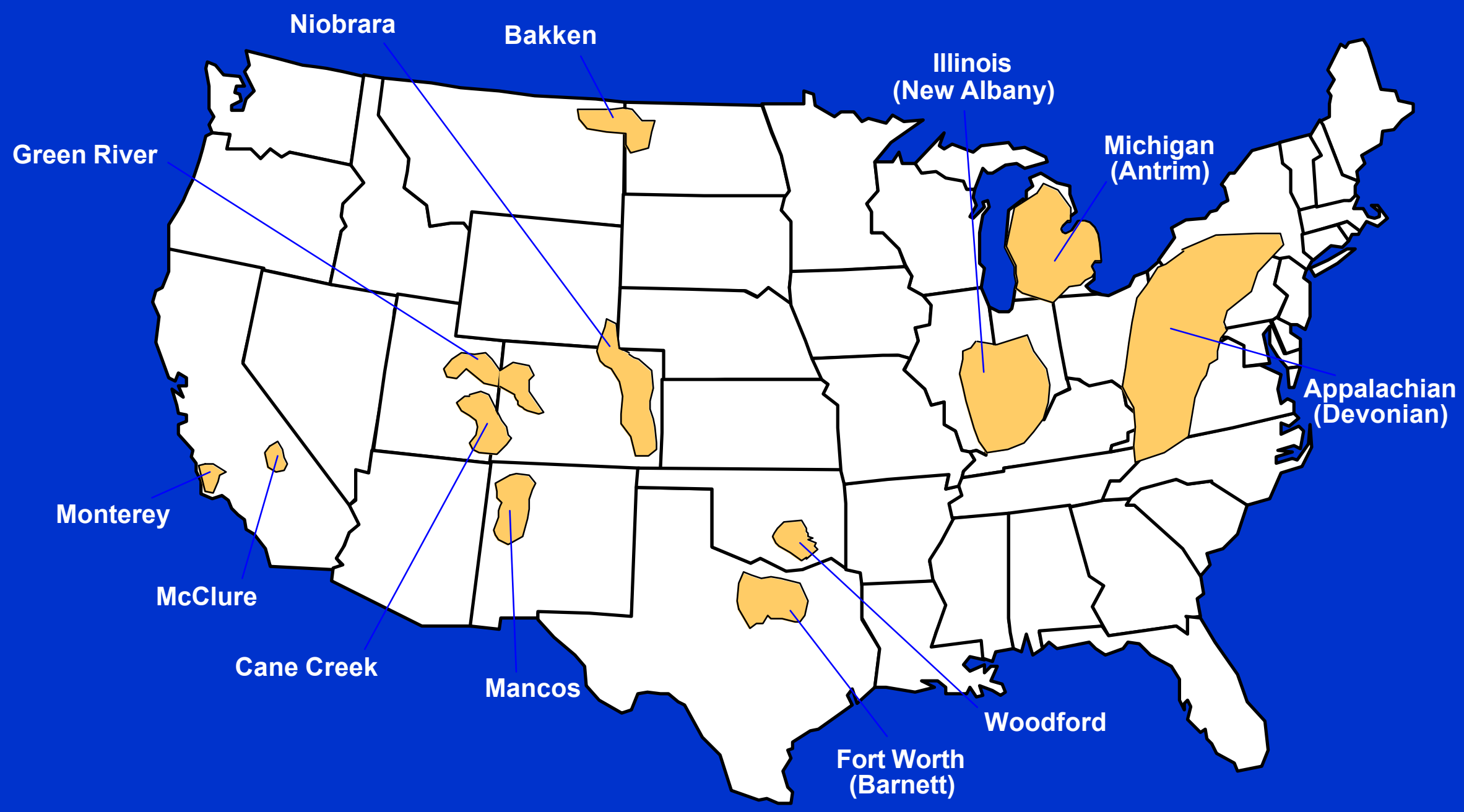

Advanced Resources International, Inc. 


\section{Gas Shales Production}

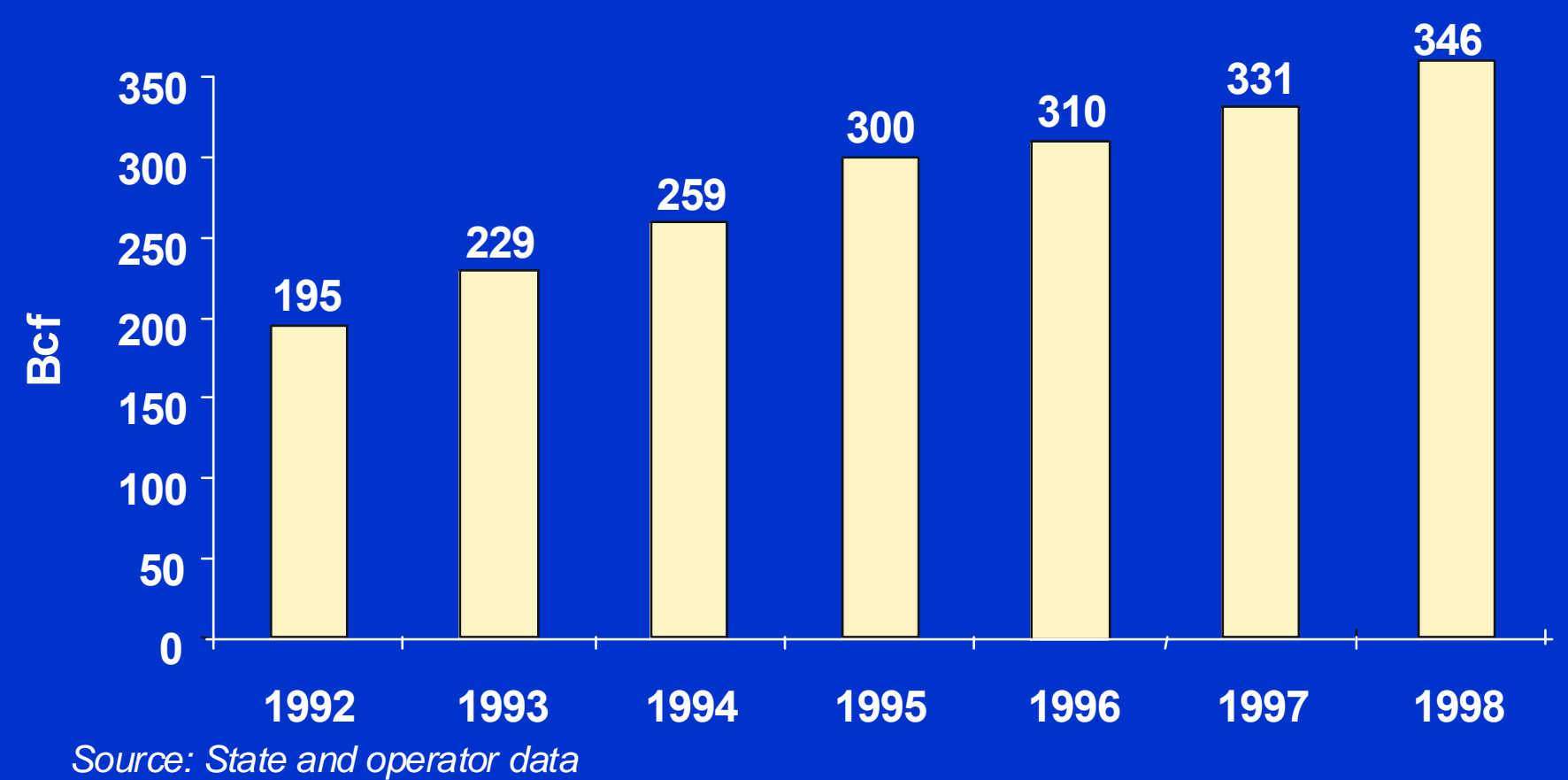

Advanced Resources International, Inc. 


\section{Gas Shales Reserves}

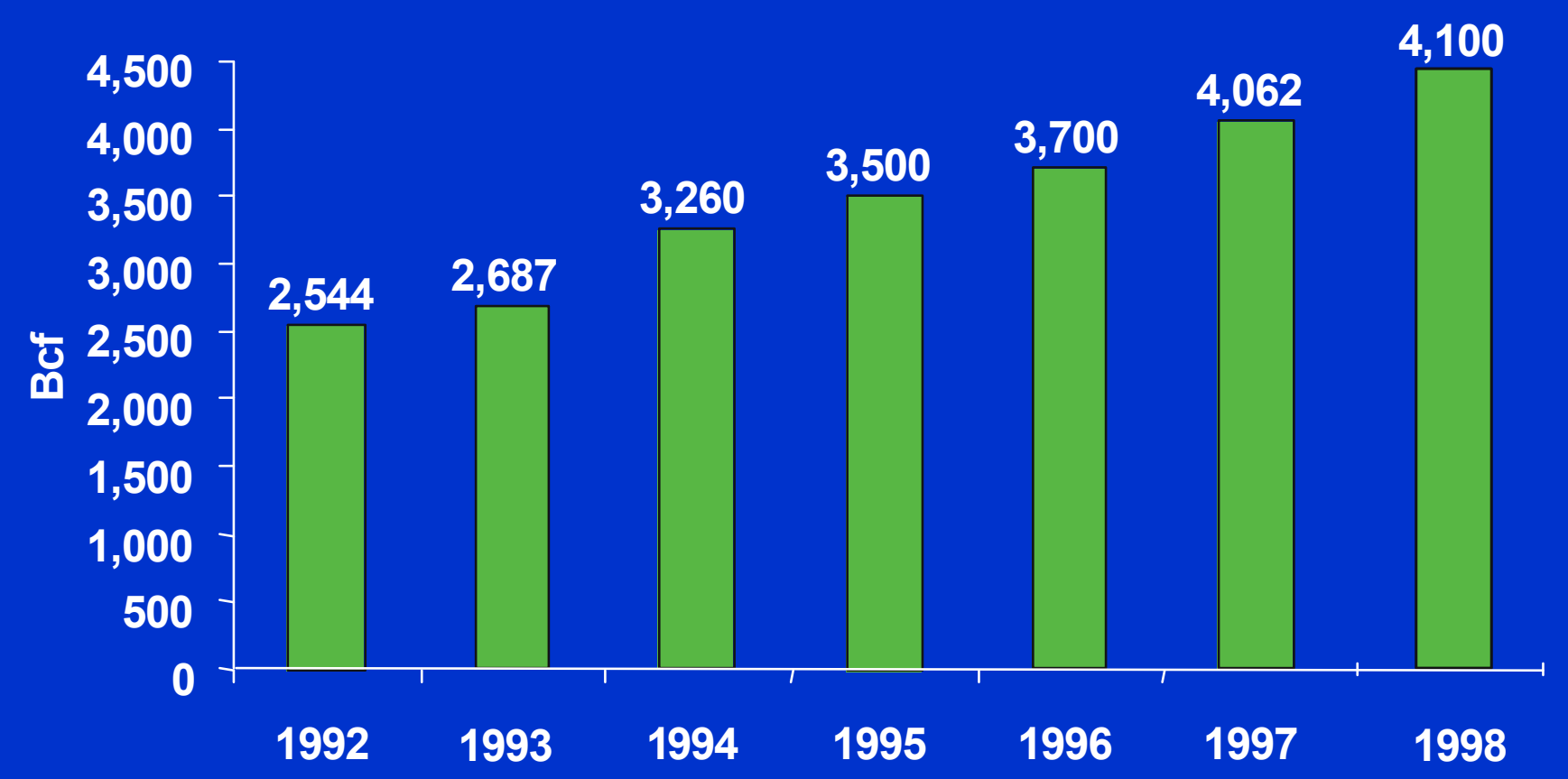

Source: State and operator data 


\section{Presentation Outline}

1. Overview of Gas Shale Production

2. Red Dog Mine Project Overview

3. Reservoir Simulation and Project Economics

4. Next Steps 


\section{Project Overview}

To date, three major tasks have been performed in support of Cominco's Red Dog Mine shale gas exploration effort:

- Feasibility Study (1997-1998)

- Coring/Gas Desorption Work (Summer, 1998)

- Coring/Gas Desorption/TOC testing (Summer, 1999) 


\section{1) Initial Feasibility Study}

ARI was contracted by Cominco to assess the feasibility of switching from diesel-based to natural gas-based power generation at the Red Dog Mine. The project requires sufficient gas reserves to supply the mine generators for a 50 -year period. The project entailed three main tasks:

- Geologic Study to determine if there is a potential gas reservoir capable of producing commercial quantities of gas within a 25-mile radius of the mine;

- Reservoir Simulation analysis to predict gas production rates and recoveries from drilled wells;

- Project Economics including gas field development, transportation, engine conversion and cost of generation in 圆/Kwh 


\section{Stratigraphy}

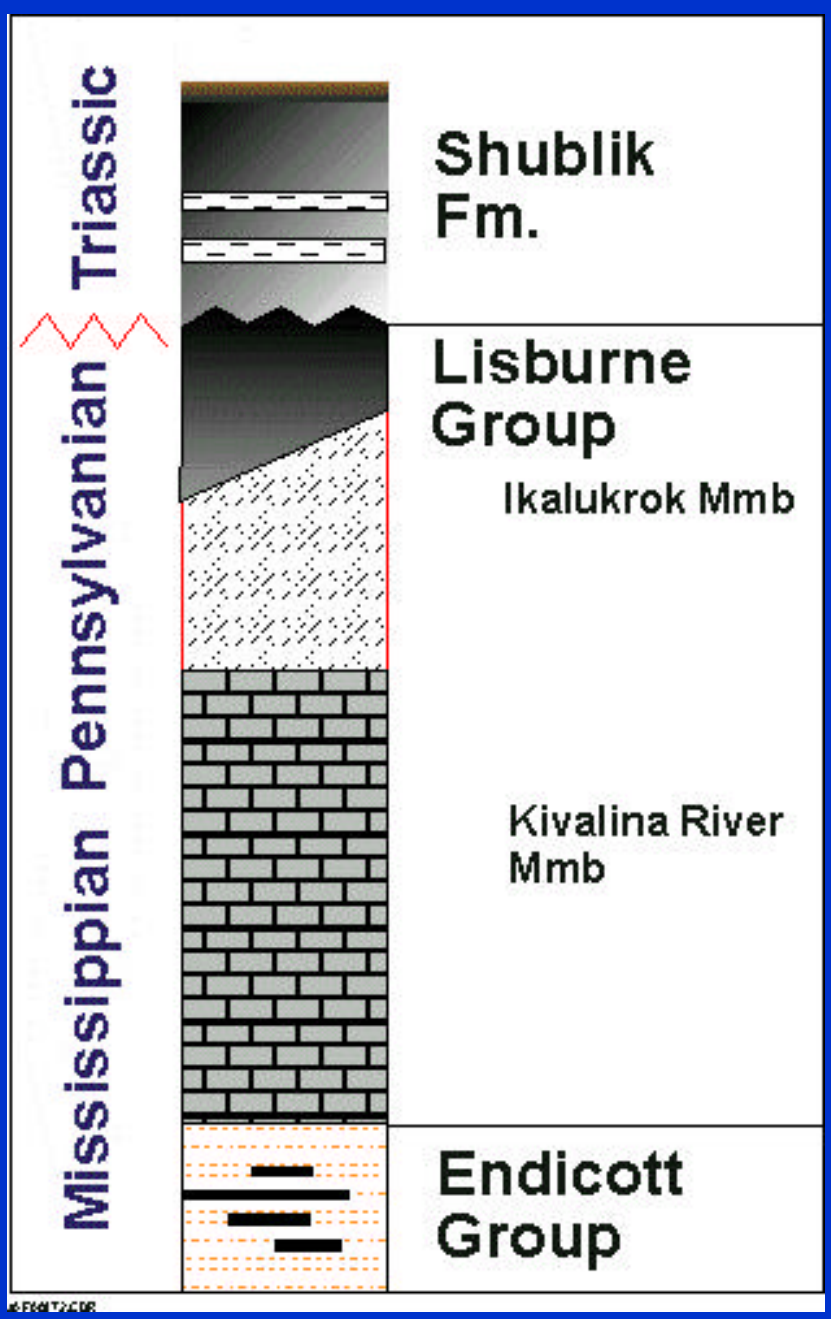

Three Stratigraphic Units were investigated as potential gas reservoirs.

- Lisburne Group

- Endicott Group

- Shublik Formation 


\section{The Results of the Initial Feasibility Study Concluded:}

1. The Lisburne Group with its thick $(3,000+$ feet) organic shale member represents a potentially large gas resource in the immediate vicinity of Red Dog;

2. Based on reservoir simulation studies, the shales may be capable of producing gas at rates similar to or greater than gas shale basins currently producing in the U.S.;

3. At a $\$ 2.50 /$ Mcf gas price, fuel costs will be reduced by $\$ 2.2$ million/year, resulting in a $\$ 111$ million savings over the life of the project. 
Limited reservoir data were available for the feasibility study which necessitated extrapolating Red Dog data and using analogs from producing shale basins in the lower 48 . Key reservoir parameters and the values used in the feasibility study were:

- Thickness:

- Gas Content:

- Permeability:

- Depth:

- Pressure Gradient:
$300 \mathrm{ft}$ (Cominco data) $100 \mathrm{cf} /$ ton (Antrim shale analog) $3,10,30 \mathrm{md}$ (range from existing basins) $1,500 \mathrm{ft}$ (Cominco data) $0.322 \mathrm{psi} / \mathrm{ft}$ (Antrim shale analog)

Because of the uncertainty surrounding some of the critical parameters, ARI recommended a gas content testing program in conjunction with planned coring operations. 


\section{2) Results of the 1998 Coring Program}

- Gas contents ranged from 10-50 scf/ton with approximately $1 / 2$ of the lkulukrok samples in the 35-50 scf/ton range; good correlation seen between gas content and TOC/bulk density as expected.

- Gas composition is $99 \%+$ methane - no $\mathrm{CO}_{2}, \mathrm{H}_{2} \mathrm{~S}$ or nitrogen detected.

- Isotherm work indicates undersaturation, however, gas bubbling from core wells contradicts this observation.

- Ikulukrok sections were 200-300 ft thick with melange dominant in some sections. 


\section{3) Results of the 1999 Coring Program}

- In 1999, drilling was stepped out into additional exploration areas (North Basin, Suds) where the geology has been less studied.

- Coring results yielded a wide range of thickness values for the lkulukrok (0-300').

- Gas content measurements confirmed 1998 results (gas content vs TOC, volume).

- Obtained an isotherm value for an average TOC value $(\sim 6 \%)$ for an lkulukrok shale. 


\section{Presentation Outline}

1. Overview of Gas Shale Production

2. Red Dog Mine Project Overview

3. Reservoir Simulation and Project Economics

4. Next Steps 


\section{Revised Reservoir Simulation Studies}

Using the core data acquired during 19981999, ARI performed a new round of reservoir simulations. The two key parameters changed in the new simulations were gas content (45 scf/ton vs 100 scf/ton), thickness (variable vs $300 \mathrm{ft}$ ), and a more representative Langmuir volume/pressure (isotherm) 


\section{Comparison of Key Reservoir Parameters Controlling Gas Production from Shales}

\begin{tabular}{l|c|c|c|c|c|}
\cline { 2 - 6 } Parameter & Antrim & Barnett & Appalachian & $\underline{\text { Lewis }}$ & $\underline{\text { Red Dog }}$ \\
$\begin{array}{l}\text { Thickness (ft) } \\
\text { Gas Content }\end{array}$ & $60-100$ & $200-300$ & $150-200$ & 1,400 & $0-300$ \\
(scf/ton) & $50-60$ & $20-40$ & $20-30$ & $25-50$ \\
Depth (ft) & $1,000-2,000$ & $7,000-8,000$ & $3,000-5,000$ & $4,000-5,000$ & $1,000-2,000$ \\
TOC & $4-8 \%$ & $4-5 \%$ & $4-5 \%$ & $4-5 \%$ & $2-15 \%$ \\
Permeability & $<1-20$ & $<1-20$ & $<1-50$ & $<1-30$ & $?$ \\
$\begin{array}{l}\text { Water Sat. } \\
\text { (\%) }\end{array}$ & 100 & $30-40$ & $0-10$ & $50-80$ & $?$ \\
$\begin{array}{l}\text { Avg. Peak } \\
\text { Production (Mcfd) }\end{array}$ & $100-130$ & $650-700$ & $80-120$ & 500 & $?$ \\
\cline { 2 - 5 } & & & & & \\
\end{tabular}




\section{Shape of Isotherm a Key Factor for Undersaturated Reservoirs}
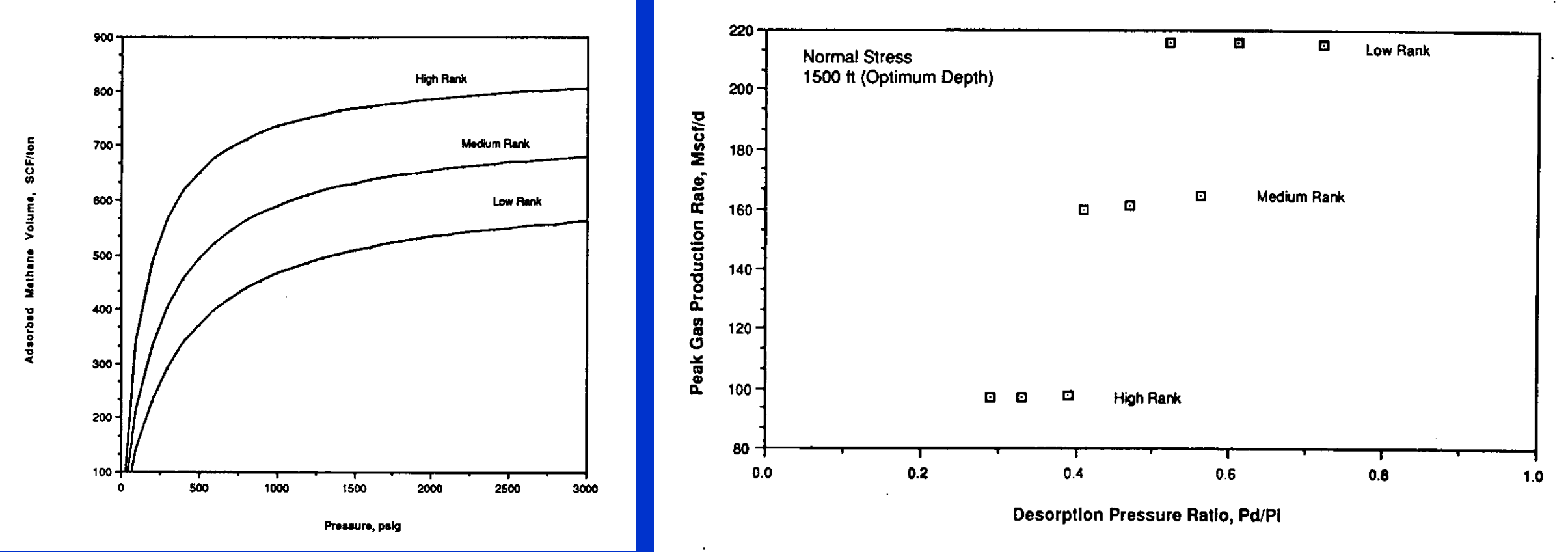

Source: Reeves, S., Decker, A.: "A Reservoir Simulation Investigation Into the Interaction of In-Situ Stress, Pore Pressure, and Coal Rank on Coalbed Methane Exploration Strategy," SPE 21490, presented at the SPE Gas Technology Symposium, Houston, TX, Jan. 23-25, 1991

Advanced Resources International, Inc. 


\section{Production Rates and Recoveries}

\begin{tabular}{|c|c|c|c|c|c|c|}
\hline \multirow[b]{2}{*}{$\begin{array}{c}\text { Shale } \\
\text { Thickness }\end{array}$} & \multirow[b]{2}{*}{$\begin{array}{c}\text { Permeability } \\
\text { (md) }\end{array}$} & \multirow[b]{2}{*}{$\begin{array}{c}\text { Peak } \\
\text { Rate } \\
\text { (Mcfd) } \\
\end{array}$} & \multicolumn{4}{|c|}{ Cumulative Production (MMcf) } \\
\hline & & & $\begin{array}{c}\text { Year } \\
1 \\
\end{array}$ & $\begin{array}{c}\text { Year } \\
\mathbf{5} \\
\end{array}$ & $\begin{array}{c}\text { Year } \\
10 \\
\end{array}$ & $\begin{array}{c}\text { Total } \\
\text { Recovery }\end{array}$ \\
\hline \multirow{3}{*}{300} & 1 & 177 & 59 & 306 & 549 & 871 \\
\hline & 3 & 429 & 157 & 1,230 & 1,041 & 1,434 \\
\hline & 10 & 1,048 & 383 & 1,804 & 1,672 & 2,102 \\
\hline \multirow{3}{*}{200} & 1 & 117 & 39 & 202 & 362 & 574 \\
\hline & 3 & 283 & 104 & 450 & 687 & 946 \\
\hline & 10 & 692 & 253 & 812 & 1103 & 1387 \\
\hline \multirow{3}{*}{100} & 1 & 58 & 19 & 101 & 181 & 287 \\
\hline & 3 & 141 & 52 & 225 & 343 & 473 \\
\hline & 10 & 346 & 126 & 406 & 552 & 694 \\
\hline
\end{tabular}




\section{Estimated Well Costs, Red Dog Mine \\ (1,500 ft. well)}

I. Capital Expenditures

1. Well Drilling, Completion and Equipping
A. Well Drilling and Completion
$\$ 320,000$
B. Well Stimulation
160,000
C. Pumping and Surface Equipment
140,000
D. Engineering and Other (@10\%)
$\underline{60,000}$

2. Lease Equipment
A. Gas Gathering System/Compression
B. Electrical \& Water Handling
C. Water Disposal System (allocated)
D. Engineering and Other (@10\%)

$\$ 80,000$

140,000

$\$ 680,000$

60,000

$\underline{40,000}$

3. Total Costs per Well 


\section{Estimated Well Costs, Red Dog Mine (1,500 ft. well)}

\section{Well and Lease Operations and Maintenance}

1. Lease Operations and Maintenance

A. Normal Well O\&M and G\&A (@\$2,000/mo.)

B. Water Handling, Power and Maintenance (@\$4,000/mo.)

1. Water Handling (@\$400/mo.)

2. Electricity (@\$1,200/mo.)

3. Well \& Pump Maintenance (@ $\$ 2,400 / m o$.

2. Metering, Treating \& Compressor Ops. (@\$0.15/Mcf)

3. $\mathrm{CO}_{2}$ Removal, Shrinkage and Fuel ( $5 \%$ of volume) 


\section{NPVI Rate of Return Matrix* - $\$ 1,000,000 / \mathrm{Well}$}

\begin{tabular}{|c|c|c|c|c|}
\hline Thickness & $30 \mathrm{md}$ & $10 \mathrm{md}$ & $3 \mathrm{md}$ & $1 \mathrm{md}$ \\
\hline $300 \mathrm{ft}$ & $\begin{array}{c}\$ 1.9 \text { million } \\
86.3 \%\end{array}$ & $\begin{array}{c}\$ 1.05 \text { million } \\
42.9 \%\end{array}$ & $\begin{array}{c}\$ 143,220 \\
13.5 \%\end{array}$ & $\begin{array}{c}(\$ 529,982) \\
-1.9 \%\end{array}$ \\
\hline $200 \mathrm{ft}$ & $\begin{array}{c}\$ 0.79 \text { million } \\
43.8 \%\end{array}$ & $\begin{array}{c}\$ 252,118 \\
18.3 \%\end{array}$ & $\begin{array}{c}(\$ 349,681) \\
0.0 \%\end{array}$ & $\begin{array}{c}(\$ 793,994) \\
--\end{array}$ \\
\hline $100 \mathrm{ft}$ & $\begin{array}{c}(\$ 255,342) \\
---\end{array}$ & $\begin{array}{c}(\$ 527,185) \\
--\end{array}$ & $\begin{array}{c}(\$ 828,084) \\
---\end{array}$ & (\$1.05 million \\
\hline
\end{tabular}

${ }^{*}$ Includes $6.25 \%$ royalty, $12 \%$ severance, discounted at $10 \%$.

Advanced Resources International, Inc. 


\section{Engine Conversion Costs}

- Red Dog currently utilizes six 16V32 engines which generate a total of $32 \mathrm{MW}$ of power

- The estimated cost to convert the engines to run on a mixture of $97 \%$ natural gas and $3 \%$ fuel oil is $\$ 7.3$ million. This includes:

- All equipment required for conversion

- Labor costs for conversion

- FOB nearest port

- The engines will require $56.5 \mathrm{Mcf} / \mathrm{hour} / \mathrm{engine}$ or a total of 8.1 MMcfd; we have rounded to 8.5 MMcf/d to provide a margin of safety 


\section{Economics of Converting to Gas-Fired Generators}

\section{Assumptions}

1. Assume $100 \%$ operational time

2. Plant produces $280,320 \mathrm{MWh} /$ year (32 MW x 24 hrs/day x 365 days)

3. Assume annual diesel fuel requirement of 13.3 million gallons and a gas requirement of $3.1 \mathrm{Bcf}$

4. Assume diesel fuel cost of $\$ 0.75 / g a l l o n$ and gas price of \$2.50/Mcf

Total annual cost for diesel fuel: $\$ 9.975$ million

Total annual cost for natural gas: $\$ 7.756$ million

Estimated annual savings: $\$ 2.2$ million or $\$ 111$ million over the life of the mine 


\section{Economics of Converting to Gas-Fired}

\section{Generators (Continued)}

Diesel: $\frac{\$ 9.975 \text { million }}{280,320,000 \mathrm{Kwh}}=\$ \mathbf{0 . 0 3 5 6 / K w h}$

Natural Gas: $\frac{\$ 7.756 \text { million }}{280,320,000 \mathrm{Kwh}}=\$ 0.0277 / \mathrm{Kwh}$

Estimated Payback Time for Conversion Costs:

$\$ 7.3$ million $=3.3$ Years

$\$ 2.2$ million 


\section{Presentation Outline}

1. Overview of Gas Shale Production

2. Red Dog Mine Project Overview

3. Reservoir Simulation and Project Economics

4. Next Steps 


\section{Next Steps}

ARI designed a sequential testing program to mitigate risk (minimize cost) at each stage of the project. At the outset of the project, we perceived two main risks in the project:

- Do the shales contain sufficient volumes of methane to serve as a gas reservoir?

- Do the shales have adequate permeability to allow the gas to flow to the wellbore in economic quantities? 


\section{Assessing Project Risk}

\section{Gas Volume}

The gas volume issue has been addressed through the gas desorption analysis of shale samples cored as part of Cominco's on-going exploration program. The ability to "piggy-back" onto this program allowed for considerable cost savings. Further gas content sampling is scheduled for this summer.

\section{Permeability}

Permeability is still unknown and represents a significant risk factor. However, because permeability in shales depends largely upon natural fracturing, one could reasonably expect some degree of permeability in the Ikulukrok due to its tectonic setting.

A well testing program has been designed to obtain permeability and other critical reservoir data. Implementation of the well testing program is awaiting lease approvals from the state and other considerations. 


\title{
SHALE GAS EXPLORATION AT THE RED DOG MINE, ALASKA
}

Opportunities in Alaskan Coalbed Methane

\author{
Sponsored by: \\ West Coast PTTC \\ Anchorage, Alaska \\ Presented by: \\ Scott R. Reeves \\ Advanced Resources International \\ March 3, 2000
}




\section{Remote Sensing Exploration for Shallow Gas}

David W. Lappi

LAPP Resources, Inc. 


\section{REMOTE SENSING EXPLORATION FOR SHALLOW GAS}

Power alternatives in the bush consist of oil, hydro (including tidal), coal, wood, wind, solar, and natural gas. Most rural villages are along major rivers that are also Tertiary coal basins which could provide "village scale" gas from coalbed gas, shallow gas, and methane hydrates.

Traditional hydrocarbon exploration relies on expensive seismic and drilling deep wells which are too expensive for rural Alaska, where there may be only 200 customers in a village. Finding shallow coalbed gas is easiest, since the gas is trapped in laterallyextensive coal deposits.

A combination of the following techniques, modified for local requirements could be used to find shallow gas deposits at low cost:

- Remote Sensing

- Ground-based geophysics including

Magnetics

EM

Radiometrics

Electrical Methods

Seismic, and

- Drilling

Of the above, Remote Sensing is the cheapest to cover the large unexplored areas of Alaska.

We have carried out a test of Landsat TM, Digital Multispectral Video imagery, and ERS-1 Radar imagery to try to detect areas of anomalous ground which may be prospective for shallow natural gas supplies in the region of Naknek Alaska. The Alaska Science and Technology Foundation and Naknek Electric Association have contributed to this work.

Image interpretation found potential areas of interest noted on the images. We found several areas south of the Naknek River which warrant further work, preferably groundbased geophysics prior to drilling shallow holes to about 2000 feet. The differing data types we are using, Landsat TM imagery, DMSV images, ERS-1 radar images, and the USGS Digital Elevation Models (DEMs) for the Naknek area, as well as the published and unpublished geological and exploration data for the region, assist the interpretation. 


\section{Coalbed Methane Exploration in Alaska Using Limited Data and Creative Approaches}

Andrew R. Scott

Bureau of Economic Geology

The University of Texas at Austin 


\title{
Review of Key Hydrogeologic Factors Affecting Coalbed Methane Producibility and Resource Assessment
}

\author{
Andrew R. Scott \\ Bureau of Economic Geology \\ The University of Texas at Austin \\ Austin, Texas 78713-8924
}

\begin{abstract}
Geologic and hydrologic comparisons of several coal basins indicate that depositional systems and coal distribution, coal rank, gas content, permeability, hydrodynamics, and tectonic/ structural setting are critical controls on coalbed methane producibility. A dynamic interplay among these controls determines high coalbed methane productivity. This paper reviews a basin-scale exploration model for the prolific and marginal gas production in two basins that can be applied to evaluation of coalbed methane potential in coal basins worldwide. High productivity is governed by (1) thick, laterally continuous coals of high thermal maturity; (2) moderate to high permeability; (3) basinward flow of ground water through coals of high rank orthogonally toward no-flow boundaries (regional hingelines, fault systems, facies changes, and/ or discharge areas); (4) generation of secondary biogenic gases; and (5) conventional trapping of migrated thermogenic and secondary biogenic gases at permeability barriers to provide additional gas beyond that generated during coalification. Understanding the dynamic interaction among geologic and hydrologic factors is important for delineating areas within basins that potentially have higher coalbed methane productivity.
\end{abstract}

\section{INTRODUCTION}

Coalbed methane is an important part of the natural gas supply for the United States and now represents more than 6 percent of total gas production and 7 percent of dry gas proved reserves (Energy Information Administration, 1998). Although coal gas exploration and development was initially performed by major oil companies and larger independents, smaller operators have played a progressively more important role in developing this natural resource. Coal gas resources are estimated to be more than $690 \mathrm{Tcf}\left(19.5 \mathrm{Tm}^{3}\right)$, more than 80 percent of which is located in the western United States (Figure 1). 


\title{
COALBED METHANE EXPLORATION IN ALASKA USING LIMITED DATA AND CREATIVE APPROACHES
}

\author{
Andrew R. Scott \\ Bureau of Economic Geology, The University of Texas at Austin \\ (512) 471-0359 or (512) 970-7041 mobile
}

Coal bed methane exploration in remote or frontier regions, such as Alaska, is often hampered by the absence of an adequate data base, thus inhibiting detailed evaluation of coal bed methane exploration potential. Gas content, permeability, and detailed hydrogeologic data are commonly absent, and coal-rank, structural, and coal-thickness data may be limited, particularly in deeper, unexplored parts of a basin. The creative application of a coal bed methane exploration model using the data that is available is necessary to delineate potential exploration fairways.

The key hydrogeologic factors affecting producibility include depositional setting and coal distribution, tectonic and structural setting, hydrodynamics, permeability, coal rank and gas generation, and gas content. Although much of this information may be difficult to obtain in areas where limited or no exploration has occurred, enough data are generally available to perform at least a preliminary assessment of the coalbed methane potential. Therefore, understanding the synergistic interplay among key hydrogeologic factors is critical to evaluating areas of potentially higher coal bed methane in remote areas.

High coalbed methane producibility commonly occurs in areas of upward flow potential that are associated with permeability barriers (no-flow boundaries). Outcrop studies combined with examination of existing geologic and permafrost maps and precipitation patterns, therefore, provide valuable information on coal resources (coal thickness and orientation), ground-water flow and permeability barriers (cleat orientation, faulting, coal pinch-out) and gas generation potential (surface coal rank and coal quality). A reas of impermeable (continuous) permafrost that may potentially trap coal gases migrating updip can be delineated from regional and local permafrost distribution maps. These data are then combined to delineate areas of potentially higher gas content and, consequently, higher coal bed methane potential.

There is no one correct technique for evaluating coal bed methane potential of frontier basins because the methods that are ultimately employed must be based entirely upon available data. The evaluation of the coal bed methane exploration potential depends heavily on the creative integration of available data with the coal bed methane producibility model. 
Annual coal gas production has increased from less than $10 \mathrm{Bcf}$ in 1986 to more than 1,003 Bcf (28.9 Bm³) in 1996 (Figure 2). Although more than 80 percent of current coal gas production is derived from the San Juan Basin, coal gas production from other western basins continues to increase. Coal gas proved reserves remained relatively constant, increasing slightly over the past 4 years, and are currently estimated to be approximately $11.5 \mathrm{Tcf}\left(325 \mathrm{Bm}^{3}\right)$. The increase in proved coal gas reserves despite the significant increase in production is attributed to the efforts of smaller operators and independents in finding new reserves. Coal gas production and reserves are expected to increase as exploration continues in unexplored areas and as secondary recovery techniques using nitrogen or carbon dioxide are employed.

The traditional view of production from coalbed methane reservoirs is inadequate to explain the contrasts in methane producibility of coal basins. This paper presents our explanation of the geological and hydrological controls that are critical to coalbed methane producibility. In the traditional view, coal gases are generated in situ during coalification and are stored primarily in micropores on the coal matrix's large internal surface area by sorption (Thimons and Kissell, 1973). The sorption process is pressure dependent, and the gas is held in coal micropores by the pressure of water in the coal's natural fracture network, or cleat system (Kolesar and others, 1990). Gas production is achieved by reducing the reservoir pressure through dewatering and thus liberating the gases from the coal matrix into the cleat system for flow to the well bore. The traditional view is oversimplified because it fails to recognize the need for additional sources of gas beyond that generated initially during coalification to achieve high gas content following basinal uplift and cooling. Migrated conventionally and hydrodynamically trapped gases, in-situ-generated secondary biogenic gases, and solution gases are required to achieve high gas contents or fully gas saturated coals for consequent high productivity. To delineate the presence and origin of these additional sources of gas requires an understanding of the interplay among coal distribution, coal rank, gas content, hydrodynamics, depositional fabric, and structural setting (Kaiser and others, 1995).

\section{Controls Critical to Coal Gas Producibility}

Coal bed methane exploration strategies are often based only on the location of the greatest net coal thickness and ignore other hydrologic and geologic factors affecting coal bed methane producibility. Coalbed methane producibility is determined by the complex interplay among six critical controls: depositional systems and coal distribution, coal rank, gas content, permeability, hydrodynamics, 
and tectonic/ structural setting (Figures 3 and 4). If one or more of these key hydrogeologic factors is missing, then the potential for higher coalbed methane producibility is reduced. However, the coalbed methane play may remain economically viable. For example, the Piceance Basin is characterized by exceptionally high gas content values (more than $700 \mathrm{scf} /$ ton; $21.8 \mathrm{~cm}^{3} / \mathrm{g}$ ), but coalbed methane production has been limited because of low permeability. The Powder River Basin remains economically successful with gas contents generally less than $30 \mathrm{scf} /$ ton $\left(0.9 \mathrm{~cm}^{3} / \mathrm{g}\right.$ ), however, because thick (more than $100 \mathrm{ft} ; 30 \mathrm{~m}$ ) coal beds are present at shallow depths. A review of each hydrogeologic factor will be followed by examples from the San Juan and Greater Green River Basins.

\section{Depositional Setting and Coal Distribution}

Coal beds are the source and reservoir for methane, indicating that their widespread distribution within a basin is critical to establishing a significant coalbed methane resource. Coal distribution is closely tied to the tectonic, structural, and depositional settings (Figure 4a) because peat accumulation and preservation as coal require a delicately balanced subsidence rate that maintains optimal water-table levels but excludes disruptive elastic sediment influx. The depositional systems define the substrate upon which peat growth is initiated and within which the peat swamps proliferate. Net coal thickness trends and depositional fabric strongly influence migration pathways and the distribution of gas content. The depositional setting also controls the types of organic matter (macerals) that affect sorption characteristics and the quantity of hydrocarbons produced from the coal. Knowledge of depositional framework enables prediction of coal bed thickness, geometry, and continuity and, therefore, the location of potential coalbed methane resources.

\section{Tectonic and Structural Setting}

The tectonic and structural setting of a basin control the distribution and geometry of coal beds in the basin during deposition and, therefore, exert a strong control on the lateral variability of maceral (Figure 4b). Both the burial history and stress direction control the timing of cleat development in various parts of the basin and the final orientation of face cleats. The basin burial history and variability of regional heat flow control coalification and the types and quantities of thermogenic gases generated from the coals. Additionally, present-day in situ stress directions may significantly affect coalbed methane producibility. Stress directions orthogonal to face cleats will lower permeability, whereas stress directions parallel to face cleat 
orientation may enhance permeability. Uplift and basinal cooling often result in, undersaturation with respect to methane in the coals and possible degassing of coal beds. Finally, the location and geometry of faults may strongly influence the recharge of meteoric water and, therefore, the generation of biogenic gases.

\section{Coal Rank and Gas Generation}

Coals must reach a certain threshold of thermal maturity (vitrinite reflectance values between 0.8 and 1.0 percent; high-volatile A bituminous) before large volumes of thermogenic gases are generated. The amount and types of coal gases generated during coalification are a function of burial history, geothermal gradient, maceral composition, and coal distribution within the thermally mature parts of a basin (Figure 4c). Gases in coal beds may also be formed through the process of secondary biogenic gas generation. Secondary biogenic gases are generated through the metabolic activity of bacteria, introduced by meteoric waters moving through permeable coal beds or other organic-rich rocks. Thus, secondary biogenic gases differ from primary biogenic gases because the bacteria are introduced into the coal beds after burial, coalification, and subsequent uplift and erosion of basin margins. The bacteria metabolize wet gas components, n-alkanes, and other organic compounds at relatively low temperatures (generally less than $150^{\circ} \mathrm{F} ; 56^{\circ} \mathrm{C}$ ) to generate methane and carbon dioxide. Secondary biogenic gases are known to occur in subbituminous through low-volatile bituminous and higher rank coals (Scott, 1993, 1994).

\section{Gas Content}

Gas content is one of the more important controls of coalbed methane producibility, yet it is often one of the more difficult parameters to accurately assess. Gas content is not fixed but changes when equilibrium conditions within the reservoir are disrupted, and it is strongly dependent upon other hydrogeologic factors and reservoir conditions (Scott and Kaiser, 1996) (Figures 4d and 5). The distribution of gas content varies laterally within individual coal beds, vertically among coals within a single well, and laterally and vertically within thicker coal beds. In general, gas content increases with depth and coal rank but is often highly variable owing to geological heterogeneities, the type of samples taken,' and/ or the analytical laboratory. The gas content of coals can be enhanced, either locally or regionally, by generation of secondary biogenic gases or by diffusion and longdistance migration of thermogenic and secondary biogenic gases to no-flow 
boundaries such as structural hingelines or faults for eventual resorption and conventional trapping.

Permeability

Permeability in coal beds is determined by its fracture (cleat) system, which is in turn largely controlled by the tectonic/ structural regime, as mentioned previously (Figure 4e). Cleats are the permeability pathways for migration of gas and water to the producing well head, and cleats may either enhance or retard the success of the coal bed methane completion. Permeability will decrease with increasing depth, suggesting that in the absence of structurally enhanced permeability at depth, coalbed methane production may be limited to depths less than 5,000 to $6,000 \mathrm{ft}$ $(1,524$ to $1,829 \mathrm{~m})$. Permeability is highly variable in coal beds ranging from darcies to microdarcies, but the most highly productive wells have permeability ranging between 0.5 to 100 md (Figure 6). Permeability that is too high results in high water production and may be as detrimental to the economic production of coalbed gas as extremely low permeability. Permeability strongly influences the recovery of coal gases from the reservoir (Figure 7).

Hydrodynamics

Hydrodynamics strongly affects coalbed methane producibility and includes the movement of meteoric water basinward as well as the migration of fluids from deeper in the basin. Basinward migration of ground water is intimately related to coal distribution and depositional and tectonic/ structural setting because groundwater movement through coal beds requires recharge of laterally continuous permeable coals at the structurally defined basin margins (Figure 4f). Coal beds not only act as conduits for gas migration but also are commonly ground-water aquifers having permeabilities that are orders of magnitude larger than associated sandstones. The presence of appreciable secondary biogenic gas indicates an active dynamic flow system with overall permeability sufficient for high productivity. Migration of thermogenic gases may result in abnormally high gas contents in lower rank coals or coals that are saturated or oversaturated with respect to methane. Basin hydrogeology, reservoir heterogeneity, location of permeability barriers (noflow boundaries), and the timing of biogenic gas generation and trap development are critical for exploration and development of unconventional gas resources in organic-rich rocks. 
Simply knowing the characteristics of the geological and hydrological controls will not lead to a conclusion about coalbed methane producibility because it is the complex interplay among these controls and their spatial relationships that governs producibility; high coal bed methane productivity requires a synergistic interplay among these controls. This synergy is evident in a comparison of the San Juan and Greater Green River/ Sand Wash Basins. The Sand Wash Basin is a subbasin of the Greater Green River Basin, where net coal beds are thickest and coal bed methane industry activity is highest (Kaiser and others, 1994a; Tyler and others, 1995)

\section{Interplay of Controls in the San Juan and Sand Wash Basins}

In terms of controls critical to coal bed methane production, the San Juan and Sand Wash Basins share comparable characteristics (Figure 8). The San Juan Basin has moderate permeability and low to high water production, whereas the Sand Wash Basin has high permeability and water production. Low to high coal rank and gas contents of the San Juan Basin are comparable to the low to moderate coal rank and gas contents of the Sand Wash Basin. Comparison of these basins, however, indicates a number of fundamental differences in the interplay of the geological and hydrological attributes, which help explain the contrasts in coalbed methane productivity.

San Juan Basin

The Upper Cretaceous Fruitland Formation is the major coal bed methane exploration target in the San Juan Basin. Fruitland coals are best developed in the north-central part of the basin (Figure 9a) and occur in several major northwesttrending belts that parallel depositional strike and are intersected by secondary northeast-trending belts parallel to depositional dip. Net coal thickness in the main northwest-trending belt is typically $50 \mathrm{ft}(15 \mathrm{~m})$ and locally exceeds $100 \mathrm{ft}(30 \mathrm{~m})$, whereas the dip-elongate belts typically contain from 30 to $50 \mathrm{ft}$ ( 9 to $15 \mathrm{~m}$ ) of net coal. The strike-parallel coals formed just landward of the progradational shorelines of the underlying Pictured Cliffs Sandstone, and the dip-oriented coals were deposited in the interchannel areas between northeast-trending Fruitland rivers, which supplied sediment to the prograding Pictured Cliffs shorelines (Ambrose and Ayers, 1991; Ayers and Kaiser, i994). The structural setting of the basin is characterized by steep dips around the northwestern, northern, and eastern margins, horizontal strata on the central basin floor, and a monocline dipping approximately 1 " to the northeast in the southern half of the basin. The intersection of the 
monocline in the southern half of the basin with the nearly horizontal strata in the central part of the basin defines a 6- to 10 -mi-wide $(9.6$ - to $16-\mathrm{km})$ structural hingeline (Figure 9a), which is inferred from the coincidence of several geological anomalies such as a change in structural attitude, a fault zone, facies transitions, marked changes in reservoir pressure, coal gas composition, and formation water (Ayers and Kaiser, 1994).

Coal-rank trends do not correspond to the present structural configuration of the basin. Although lower rank high-volatile $C$ bituminous coals occur in the shallow southern part of the basin and along the basin margins and coal rank generally increases in the deeper parts of the basin, the highest rank coal (lowvolatile bituminous) occurs at intermediate depths in the northernmost part of the basin. The coal-rank trends suggest that significant local, postcoalification basin uplift and/ or higher heat flux occurred in this area (Scott and others, 1991). The gas content of Fruitland coals generally increases with burial depth and pressure but does not necessarily correspond to increasing rank; high-volatile A bituminous coals along the structural hingeline have gas contents ( 400 to $600 \mathrm{scf} /$ ton $=12.48$ to $18.72 \mathrm{~cm}^{3} / \mathrm{g}$ ) that would normally be expected of medium- and low-volatile bituminous coals. These unusually high gas contents in lower rank coals are related to conventional hydrodynamic trapping of migrated gases along a structural hingeline (Kaiser and Ayers, 1991; Ayers and Kaiser, 1992, 1994) and generation of secondary biogenic gases from the coals (Scott and others, 1991, 1994a).

Ground-water recharge occurs mainly at the elevated, wet, northern basin margin in the foothills of the San Juan Mountains. The strongly cleated Fruitland coals are the primary aquifers and are orders of magnitude more permeable than associated low-permeability sandstones. These coal beds accept and transmit recharge from the outcrop belt along the northern basin margin basinward (southward), where flow turns sharply up at the basinward pinch-out of the coals and/ or at their offset near faults along the structural hingeline (no-flow boundary). Ground water flows orthogonally toward the no-flow boundary through the area of highest rank coals, resulting in relatively large volumes of gas to be dissolved or entrained and swept basinward in meteoric water for resorption and conventional trapping along the structural hingeline (Kaiser and Ayers, 1991).

\section{Greater Green River/ Sand Wash Basin}

The Upper Cretaceous Williams Fork Formation and lower Tertiary Fort Union Formation are the major coal-bearing units in the greater Green River Basin. Upper Cretaceous coals are widespread and thickest in the southeastern half of the Greater 
Green River Basin, predominantly in the Sand Wash Basin (Figure 9b) where average net coal thickness exceeds $200 \mathrm{ft}$ (>61 m). The thickest, most laterally extensive coals accumulated in a coastal-plain setting behind northeast-southwestoriented linear-shoreline systems. Bypass of coarse clastic sediment, maintenance of high water tables, and optimal rate of subsidence in this setting provided ideal conditions for peat accumulation and preservation (Hamilton, 1993).

The major lower Tertiary coal bed methane target of the Sand Wash Basin is the lower coal-bearing unit of the Paleocene Fort Union Formation (Tyler and others, 1994, 1995). Deposition of the Fort Union Formation was controlled by syntectonic sedimentation, and depositional systems consist of intermontane-fluvial, floodplain, lacustrine, and paludal deposits. The lower coal-bearing unit of the Fort Union Formation contains north-trending fluvial sandstones and floodplain coal beds, which are laterally continuous above the thickest intermontane fluvial-trunk stream development in the center of the basin. An increase in the suspended load carried by the fluvial system resulted in the building of levees that stabilized the channel axes and allowed the formation of extensive floodplains. Coal beds are thicker and more numerous in floodplain areas above and on the flanks of the thickest fluvial sandstones, where some of the thickest individual coal beds are as much as $50 \mathrm{ft}(15 \mathrm{~m})$ thick. Net coal thickness ranges from 0 to $80 \mathrm{ft}(0$ to $24 \mathrm{~m})$ in as many as 12 seams at depths as much as $8,000 \mathrm{ft}(2,440 \mathrm{~m})$ below surface (Tyler and others, 1994, 1995).

Despite good reservoir quality, low gas content and hydrodynamics account for the low gas production and high water production to date from coals in the Sand Wash Basin. The low to moderate gas contents in the basin reflect lower coal rank. Most coal beds are high-volatile $\mathrm{C}$ to $\mathrm{B}$ bituminous rank or lower, having gas contents generally less than $200 \mathrm{scf} /$ ton $\left(<6.24 \mathrm{~cm}^{3} / \mathrm{g}\right)$. Lower Williams Fork coals were not deposited in the western part of the basin where the highest levels of thermal maturity occur and thus could not serve as conduits for long-distance migration of gas (Figure 9b). Moreover, the regional ground-water flow is east to west, from areas of low thermal maturity to high thermal maturity, indicating that relatively small volumes of coal gas may be available for solution and entrainment for basinward resorption and conventional trapping (Kaiser and others, 1994b). High permeabilities of the Upper Cretaceous coal beds (tens to thousands of millidarcys) and their communication with recharge areas at the eastern and southern outcrop belts contribute to excessive water production, which may prove to be uneconomical for coalbed methane production. The Williams Fork is hydraulically interconnected regionally with good vertical connectivity, reflecting a lack of seals and few permeability contrasts, which is also indicated by the absence of regionally extensive 
abnormal pressure regimes (Kaiser, 1993). The absence of permeability contrasts decreases the chances for conventional trapping and increases the chances for gas loss through flushing.

\section{Basin Comparison}

Simply understanding the geologic and hydrologic characteristics of a basin will not lead to a conclusion about coalbed methane producibility because it is the interplay among geologic and hydrologic controls on production and their spatial relation that governs producibility. High producibility requires that controls be synergistically combined. The importance of this synergism to coalbed methane producibility is evident in a comparison of the prolific San Juan Basin and marginally producing Sand Wash Basin, which are thought to represent end members of a producibility continuum (Figure 9a and 9b). A reas of thick coal and high thermal maturity coincide in the San Juan Basin to maximize thermogenic methane generation, whereas coals are absent in the most thermally mature part of the Sand Wash Basin, thus minimizing thermogenic methane generation. In the San Juan Basin, ground water flows through higher rank coals toward a structural hingeline and associated permeability barrier, or no-flow boundary. However, in the Sand Wash Basin, ground water flows across an area of low thermal maturity toward a major fault zone that is leaky to flow.

Because of the dynamic interaction among geologic and hydrologic factors in the San Juan Basin, a relatively large volume of gas is available to be swept basinward for conventional trapping at the hingeline and, coupled with high coal permeability, accounts for exceptionally high gas production and relatively low water production along this zone. Additionally, secondary biogenic gases were generated by bacteria transported basinward by meteoric water moving through permeable coal beds. Therefore, trapping of thermogenic and secondary biogenic gases along the hingeline combines conventional and hydrodynamic elements and provides an additional source of gas (Figure 10). The presence of permeability contrasts in the San Juan Basin is implicit in regional overpressure and underpressure (Kaiser, 1993), whereas their apparent absence in the Sand Wash Basin suggests good aquifer interconnectedness and less potential for conventional traps and trapping. 
Accurately assessing coal and coal bed methane resources and delineating areas within basins that contain the largest resources are important aspects of resource development. The coal bed methane producibility model can be used to predict areas within basins that may have higher than expected gas contents. Gas content variability is one of the more difficult parameters to constrain during resource calculations (Scott and others, 1995). However, ash-free gas content data in addition to net coal thickness, coal rank, ash content, and ash-free and bulk coal density values can be contoured, digitized, and converted into a grid and note system for coal and coalbed methane resource calculations if sufficient data are available. Modified approaches to coal and coalbed methane resource calculations are required in the absence of sufficient data or well control (Scott and others, 1995). Accurate assessment of resources and application of the producibility model may provide a basis for economic evaluation of coal and coalbed methane resources on the basis of incremental increases in drilling depth. Additionally, specific areas in the basin having large gas resources can be delineated, providing a basis for future exploration efforts. Therefore, accurate determination of coal bed methane resources is important in assessing the potential of future coalbed methane production.

\section{CONCLUSIONS}

The complex interplay and spatial relationship among coal distribution, coal rank, gas content, permeability, hydrodynamics, and depositional and tectonic/ structural setting govern the occurrence and production of coal bed methane. High productivity requires that these controls be synergistically combined. In the San Juan Basin, they are combined synergistically, resulting in prolific production because ground water flows through thick coals of high thermal maturity toward a structural hingeline (no-flow boundary). The relatively large volume of gas available in thermally mature coals and secondary biogenic gases generated by bacteria after uplift and basinal cooling are swept basinward for conventional trapping along the hingeline, providing additional sources of gas beyond that sorbed initially on the coal surface. Conventional trapping plays a much more important role in coalbed methane production than is generally recognized. In the Sand Wash Basin, flow is basinward through thick coals of low thermal maturity, suggesting that only relatively small volumes of thermogenic gases are available to be swept basinward for conventional trapping along potential flow barriers. Moreover, Upper Cretaceous coals did not accumulate in the most 
thermally mature parts of the basin, indicating that relatively large volumes of thermogenic gases were never generated. Coalbed methane potential in the Sand Wash Basin was further inhibited by high coal permeability and interconnectedness, which promoted dynamic ground-water flow and, consequently, extremely high water production. The conceptual model provides a rationale for exploration and development strategies and has application in both the United States and frontier basins of China for evaluating coalbed methane resource potential or for finding "sweet spots" in basins having established production.

\section{ACKNOWLEDGMENTS}

This paper summarizes more than a decade of coalbed methane research performed by a creative research team consisting of W. R. Kaiser, Walter B. Ayers, Jr., Roger Tyler, Douglas S. Hamilton, and Andrew R. Scott. The encouragement and support of the Energy Minerals Division of the American Association of Petroleum Geologists is also acknowledged. Word processing was by Susan Lloyd, and editing was performed under the direction of Susie Doenges. Drafting was provided by the Graphics staff of the Bureau of Economic Geology under the supervision of Joel Lardon. The concepts discussed in this paper evolved from coalbed methane research funded by the Gas Research Institute under contracts 5087-214-1544 and 5091-214-2261. Publication was authorized by the Director, Bureau of Economic Geology, The University of Texas at Austin.

\section{REFERENCES}

A mbrose, W. A., and Ayers, W. B., Jr., 1991, Geologic controls on coal bed occurrence, thickness, and continuity, Cedar Hill field and the COAL site, in Ayers, W. B., $J r .$, and others, Geologic and hydrologic controls on the occurrence and producibility of coalbed methane, Fruitland Formation, San Juan Basin: Chicago, Gas Research Institute, Topical Report, GRI-91/0072, p. 47-68.

Ayers, W. B., Jr., and Kaiser, W. R., 1992, Coal bed methane occurrence and producibility, Fruitland Formation, Navajo Lake Area, San Juan Basin, New Mexico, in Ryan, B., and-Cunningham, J., eds., Proceedings, The Canadian Coal and Methane Geoscience Forum: Alberta Geological Survey, Alberta Research Council, p. 4-20. 
Ayers, W. B., Jr., and Kaiser, W. R., eds., 1994, Coalbed methane in the Upper Cretaceous Fruitland Formation, San Juan Basin, New Mexico and Colorado: The University of Texas at Austin, Bureau of Economic Geology Report of Investigations No. 218; Colorado Geologic Survey, Department of Natural Resources, Resource Series 31; and New Mexico Bureau of Mines and Mineral Resources Bulletin 146, 216 p.

Bryer, C. W., and Guthrie, H. D., 1999, A ppalachian coals: potential reservoirs for sequestering carbon dioxide emissions from power plants while enhancing CBM production: Proceedings of the 1999 International Coalbed Methane Symposium, The University of Alabama, College of Continuing Education, Tuscaloosa, Alabama, p. 319-328.

Energy Information Administration, 1998, Crude oil, natural gas, and natural gas liquids reserves, 1997 Annual Report, DOE/ EIA - 0216(97), Coalbed Methane, p. 34-35.

Hamilton, D. S., 1993, Stratigraphy and coal occurrence of the Upper Cretaceous Mesaverde Group, San Wash Basin, in Kaiser, W. R., and others, Geologic and hydrologic controls on coalbed methane: San Wash Basin, Colorado and Wyoming: Chicago, Gas Research Institute, Topical Report, GRI-92/0420, p. 2349.

Kaiser, W. R., 1993, Abnormal pressure in coal basins of the western United States: The University of Alabama, Proceedings, 1993 International Coalbed Methane Symposium, paper 9333, v. 1, p. 173-186.

Kaiser, W. R., and Ayers, W. B., Jr., 1991, Geologic and hydrologic characterization of coal bed methane reservoirs, Fruitland Formation, San Juan Basin, Colorado and New Mexico: Richardson, Texas, Society of Petroleum Engineers, SPE paper 23458, v. 1, p. 173-186.

Kaiser, W. R., Scott, A. R., Hamilton, D. S., Tyler, Roger, McMurry, R. G., Naijiang, Zhou, and Tremain, C. M., 1994a, Geologic and hydrologic controls on coal bed methane: Sand Wash Basin, Colorado and Wyoming: The University of Texas at Austin, Bureau of Economic Geology Report of Investigations No. 220, and Colorado Geologic Survey, Department of Natural Resources, Resource Series 30,151 p. 
Kaiser, W. R., Hamilton, D. S., Scott, A. R., and Tyler, Roger, 1994b, Geological and hydrological controls on the producibility of coalbed methane: Journal of the Geological Society, v. 151, p. 417420.

Kaiser, W. R., Scott, A. R., and Tyler, Roger, 1995, Geology and hydrology of coalbed methane producibility in the United States: analogs for the world: Tuscaloosa, The University of Alabama, Intergas '95 Short Course, 516 p.

Kolesar, J. E., Ertekin, T., and Obut, S. T., 1990, The unsteady-state nature of sorption and diffusion phenomena in the micropore structure of coal: part I-theory and mathematical formulation: SPE Formation Evaluation, v. 5, p. 81-88.

Scott, A. R., 1993, Composition and origin of coal bed methane from selected basins in the United States: The University of Alabama, Proceedings, 1993 International Coalbed Methane Symposium, paper 9370, v. 1, p. 207-222.

Scott, A. R., 1994, Composition of coalbed gases: In Situ, v. 18, no. 2, p. 185-208.

Scott, A. R., 1999, Improving coal gas recovery with microbially enhanced coalbed methane, in Mastalerz, M., Glickson, M., and Golding, S. D., eds., Coalbed methane: scientific, environmental, and economic evaluation: Kluwer Academic Publishing, p. 89-110.

Scott, A. R., and Kaiser, W. R. , 1996, Factors affecting gas content distribution in coal beds: a review (exp. abs.), in Expanded abstracts volume, Rocky Mountain Section Meeting: American Association of Petroleum Geologists, p. 101-106.

Scott, A. R., Kaiser, W. R., and Ayers, W. B., Jr., 1991, Composition, distribution, and origin of Fruitland and Pictured Cliffs sandstone gases, San Juan Basin, Colorado and New Mexico, in Schwochow, S. D., ed., Coalbed methane of western North America: Rocky Mountain Association of Geologists Guidebook, p. 93-108.

Scott, A. R., Kaiser, W. R., and Ayers, W. B., Jr., 1994a, Thermogenic and secondary biogenic gases, San Juan Basin, Colorado and New Mexico-implications for coalbed gas producibility: American Association of Petroleum Geologists Bulletin, v. 78, no. 8, p. 1186-1209. 
Scott, A. R., Tyler, Roger, Hamilton, D. S., Zhou, Naijiang, 1994b, Coal and coal gas resources of the Greater Green River Basin: application of an improved approach to resource estimation, in Sonneburg, S. A., compiler, Rocky Mountain Association of Geologists and Colorado Oil and Gas Association, First Biennial Conference: Lakewood, Colorado, Natural Gas in the Western United States, unpaginated (4 pages).

Scott, A. R., Zhou, Naijiang, and Levine, J. R., 1995, A modified approach to estimating coal and coal gas resources: example from the Sand Wash Basin, Colorado: American Association of Petroleum Geologists, v. 79, p. 1320-1336.

Thimons, E. I'., and Kissell, F. N., 1973, Diffusion of methane through coal: Fuel, p. 274-280.

Tyler, Roger, Kaiser, W. R., Scott, A. R., Hamilton, D. S., McMurry, R. G., and Zhou, Naijiang, 1994, Geologic and hydrologic assessment of natural gas from coal seams in the Mesaverde Group and Fort Union Formation, Greater Green River Basin, Wyoming and Colorado: The University of Texas at Austin, Bureau of Economic Geology, topical report prepared for the Gas Research Institute under contract no. 5091-214-2261 (GRI-93/ 0320), 120 p.

Tyler, Roger, Kaiser, W. R., Scott, A. R., Hamilton, D. S., and Ambrose, W. A., 1995, Geologic and hydrologic assessment of natural gas from coal: Greater Green River, Piceance, Powder River, and Raton Basins, Western United States: The University of Texas at Austin, Bureau of Economic Geology, Report of Investigations No. 228, 219 p.

Zuber, M. H., 1999, Coalbed methane production and well completion methods: Workshop Notes on Developing a Model for Coalbed Methane Exploration and Production Technology in Louisiana, presented by the Central Gulf Region of the Petroleum Technology Transfer Council, September 1, 1999, Baton Rouge, Louisiana, variously paginated. 


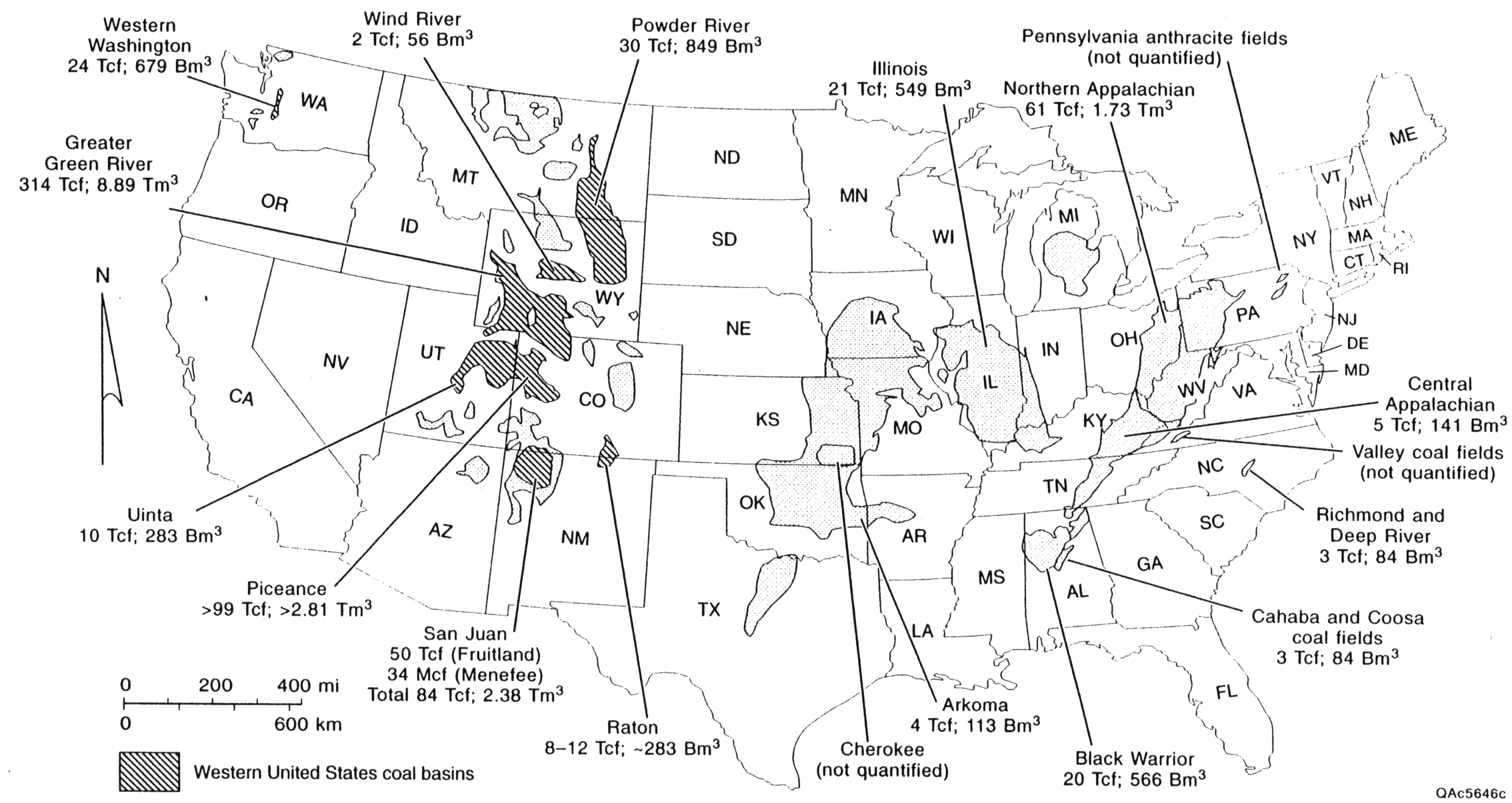

Figure 1. Coal basins and coalbed gas resources of the United States. Total coalbed gas resources are estimated at 690 Tcf $\left(19.5 \mathrm{Tm}^{3}\right)$. From Scott and others (1994b). 


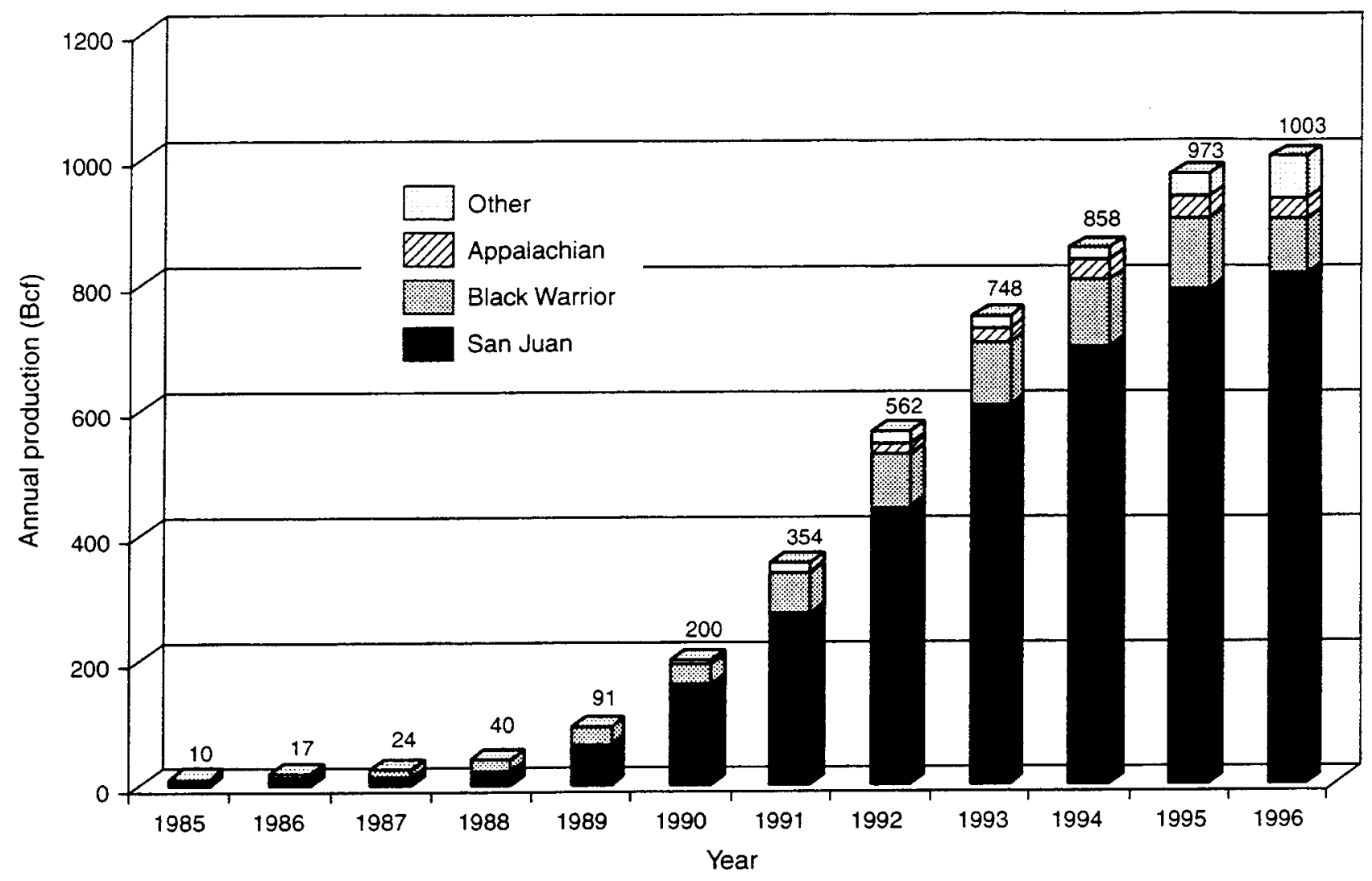

Figure 2. Coal gas production trends in the United States (Bryer and Guthrie, 1999). Coal gas production has increased significantly since 1985 and has consistently represented approximately 6 percent of the total dry gas production in the United States for the past several years. 


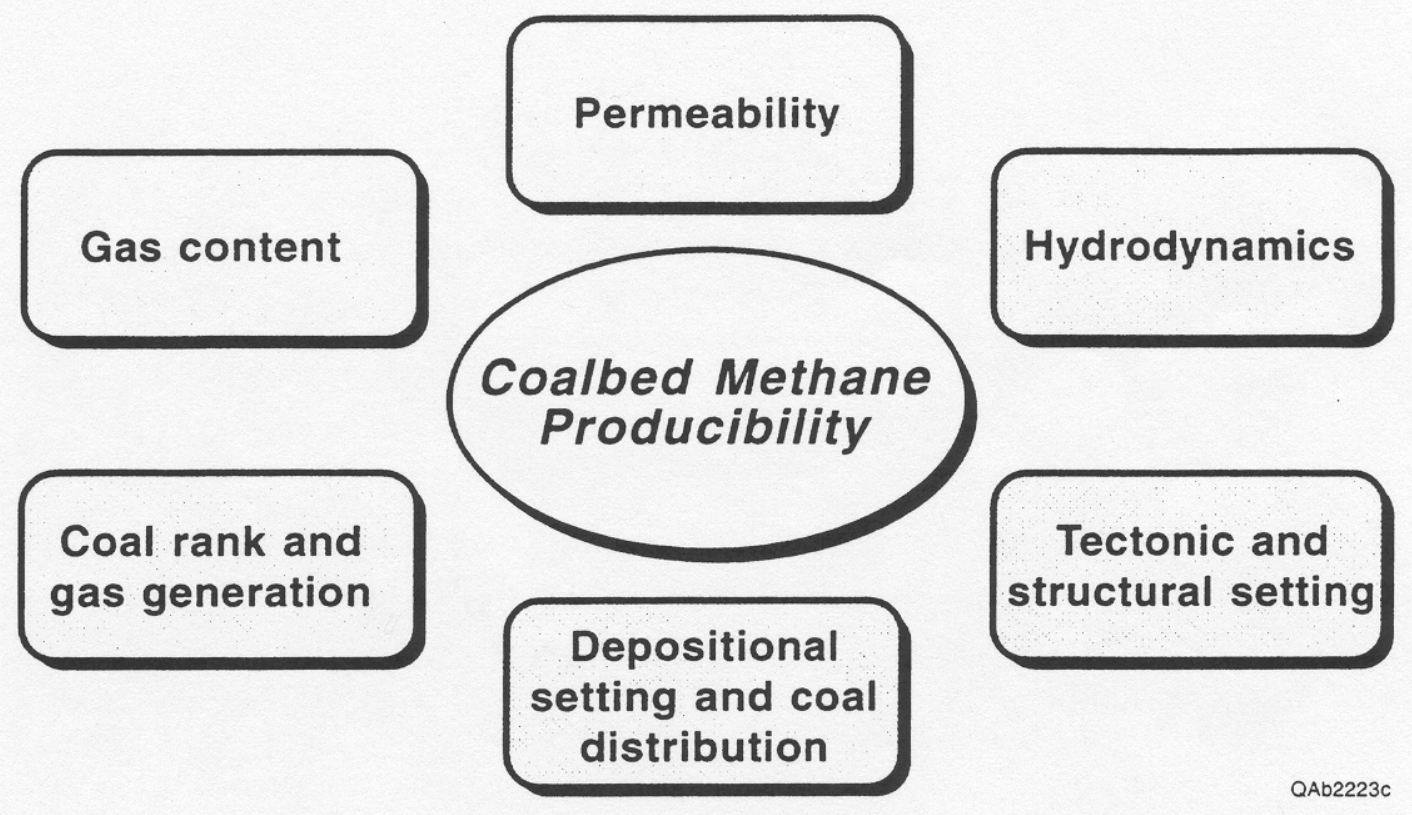

Figure 3. Geologic and hydrologic controls critical to coalbed gas producibility. A dynamic interaction among these controls and their spatial relations governs producibility. 
(a)

\begin{tabular}{|l|l|}
\hline \multicolumn{1}{|c|}{ DEPOSITIONAL SETTING AND COAL DISTRIBUTION } \\
\hline Tectonic setting & $\begin{array}{l}\text { Regionally affects geometry occurrence, and } \\
\text { thickness of coal beds } \\
\text { Recharge and ground-water flow influenced } \\
\text { by coal continuity and geometry } \\
\text { Local permeability enhancement associated } \\
\text { with compaction over sandstones }\end{array}$ \\
Gas content & $\begin{array}{l}\text { Maceral composition afects gas sorption } \\
\text { and desorption rates } \\
\text { Maceral type affects hydrocarbon generation } \\
\text { gas generation and types of hydrocarbons }\end{array}$ \\
\hline
\end{tabular}

(b)

\begin{tabular}{|l|l|}
\hline \multicolumn{2}{|c|}{ TECT ONIC AND STR UCTUR AL SETTING } \\
\hline $\begin{array}{l}\text { Depositional setting } \\
\text { gas generation }\end{array}$ & $\begin{array}{l}\text { Regionally controls orientation, geometryand } \\
\text { occurrence of facies and coal beds } \\
\text { Burial history, coalification, gas generation, and } \\
\text { timing of cleat development } \\
\text { Uplift and cooling produces undersaturation and } \\
\text { possible degassing of coals } \\
\text { Dermeability } \\
\text { Decreases with depth; cleat orientation; } \\
\text { pydrodynamics } \\
\text { Hydrologic control on peat accumulation; uplift of } \\
\text { basin margins for recharge; is olation of coals } \\
\text { from outcrop }\end{array}$ \\
\hline
\end{tabular}

(c)

\begin{tabular}{|c|c|}
\hline \multicolumn{2}{|c|}{ COAL RANK AND GAS GENER A TION } \\
\hline Gas content & $\begin{array}{l}\text { Thermogenic gas generation may result in } \\
\text { higher gas contents }\end{array}$ \\
\hline Depositional setting & $\begin{array}{l}\text { The presence of thick, thermally mature coals } \\
\text { enhances coalbed methane producibility }\end{array}$ \\
\hline Tectonic setting & $\begin{array}{l}\text { Burial his tory controls coalification and } \\
\text { thermogenic gas generation }\end{array}$ \\
\hline Hydrodynamics & $\begin{array}{l}\text { Wet gases and condensate converted into } \\
\text { secondary biogenic methane by bacteria }\end{array}$ \\
\hline Permeability & $\begin{array}{l}\text { Cleat frequency and, therefore, permeability } \\
\text { increase with increasing rank }\end{array}$ \\
\hline
\end{tabular}

(d)

\begin{tabular}{|l|l|}
\hline \multicolumn{2}{|c|}{ GAS CONTENT } \\
\hline gas generation & $\begin{array}{l}\text { Generally increases with coal rank and depth; } \\
\text { updip migration; dif fusion coeficients } \\
\text { Macerals affect gas sorption and desorption; } \\
\text { shale seals; coal thickness and continuity } \\
\text { Conventional trapping of gases at faults and } \\
\text { anticlines; burial history; diagenesis } \\
\text { Secondary biogenic methane; high or low gas } \\
\text { Content at convergent flow; low gas content } \\
\text { possible near recharge zone } \\
\text { High permeability near recharge zone may } \\
\text { allow flushing and low gas content }\end{array}$ \\
\hline
\end{tabular}

(e)

\begin{tabular}{|c|c|}
\hline \multicolumn{2}{|r|}{ PERME ABILITY } \\
\hline Hydrodynamics & $\begin{array}{l}\text { Meteoric recharge and enhanced near outcrop; } \\
\text { diagenesis in sands; low/high permeability } \\
\text { detrimental }\end{array}$ \\
\hline Tectonic setting & $\begin{array}{l}\text { Decreases with depth; present-day in-situ } \\
\text { stresses; enhancement with structures; fault } \\
\text { barriers }\end{array}$ \\
\hline Depositional setting & $\begin{array}{l}\text { Enhancement through compaction; sands as } \\
\text { barriers; coal pinch-out; macerals and cleats }\end{array}$ \\
\hline $\begin{array}{l}\text { Coal rank and } \\
\text { gas generation }\end{array}$ & $\begin{array}{l}\text { Cleat frequency increases with rank; annealing; } \\
\text { cleats filled with bitumen and minerals }\end{array}$ \\
\hline Gas content & $\begin{array}{l}\text { High permeability and flushing; high gas } \\
\text { content and moderate permeability }\end{array}$ \\
\hline
\end{tabular}

(f)

\begin{tabular}{|l|l|}
\hline \multicolumn{2}{|c|}{ HYDRODYNAMICS } \\
\hline Tectonic setting & $\begin{array}{l}\text { Uplifted margins; faults as flow barriers; flow } \\
\text { enhancement along structures; is olation of } \\
\text { outcrop coals; in-situ stresses; cross flow } \\
\text { Depositional setting } \\
\text { coal aquifer continuity; macerals and cleats }\end{array}$ \\
$\begin{array}{l}\text { Coal rank and } \\
\text { gas generation } \\
\text { Gas content } \\
\text { updip migration thermogenic gases }\end{array}$ \\
$\begin{array}{l}\text { High with convergent flow and permeability } \\
\text { barriers; } \\
\text { Water production implies permeability; high and } \\
\text { low permeability detrimental; bacteria }\end{array}$ \\
\hline
\end{tabular}

Figure 4. Synergistic interplay among the key geologic and hydrologic factors affecting producibility. (a)depositional setting and coal distribution, (b)tectonic and structural setting, (c) coal rand and gas generation. 
Gas Generation

Coal Rank

Maceral composition

Hydrogeology

\section{Coal Properties}

Ash content

Moisture content Maceral composition

Permeability

Diffusion coefficient
Reservoir Conditions

Reservoir pressure

Reservoir temperature

Coal geometry

Hydrogeology

Conventional trapping

Figure 5. Primay factors affecting gas content distribution in coal beds. Gas content is not fixed but changes when equilibrium conditions in the reservoir change. From Scott and Kaiser (1996). 


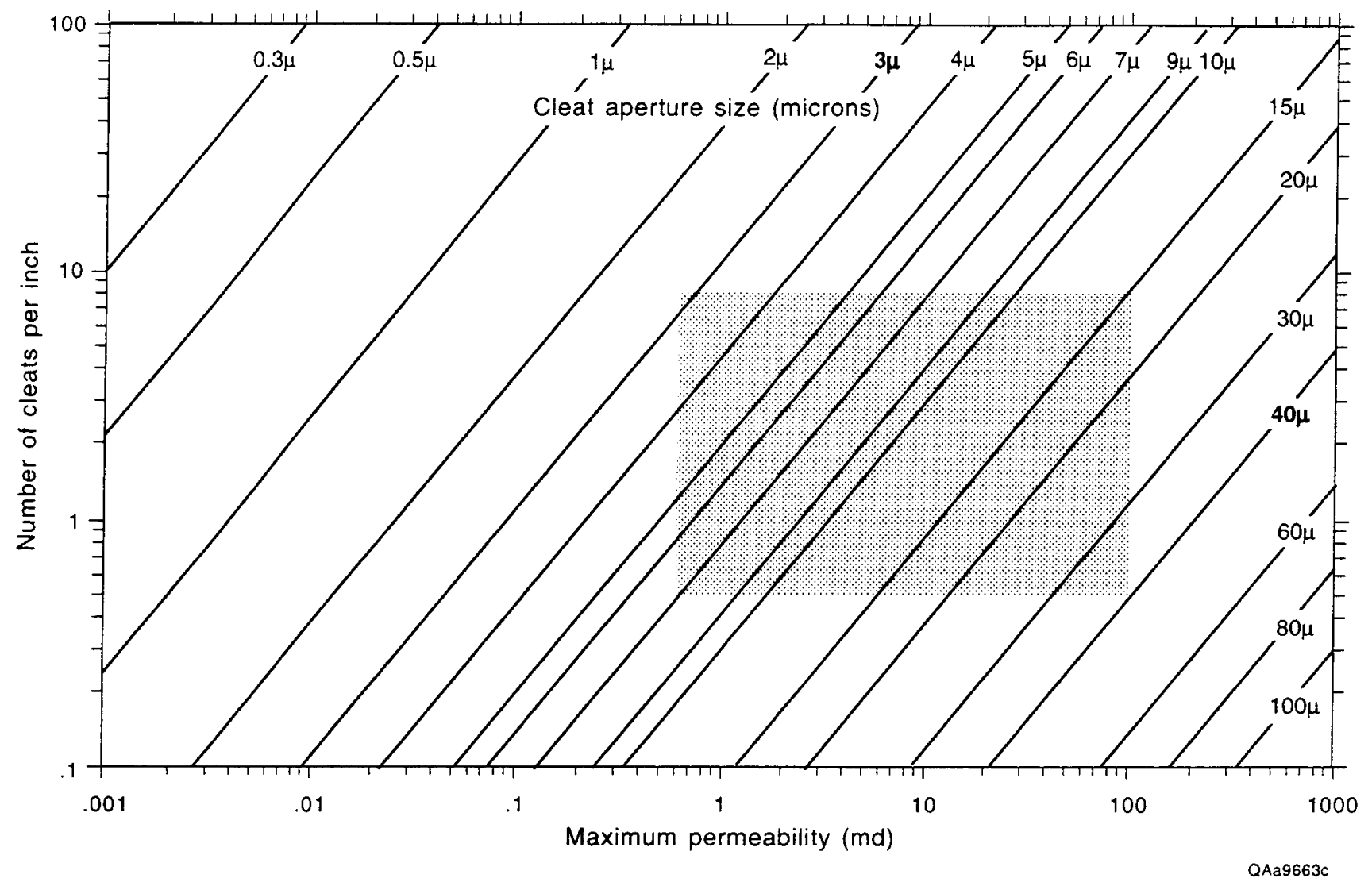

Figure 6. Relationship among face-cleat spacing, permeability, and cleat aperture. Cleat tortuosity will decrease fluid permeability, suggesting that cleat-aperture size in the subsurface may be larger than the apertures indicated on this figure. The range of permeability in highly productive coalbed methane wells in the San Juan and Black Warrior Basins is shown in the stippled pattern. From Scott (1999). 


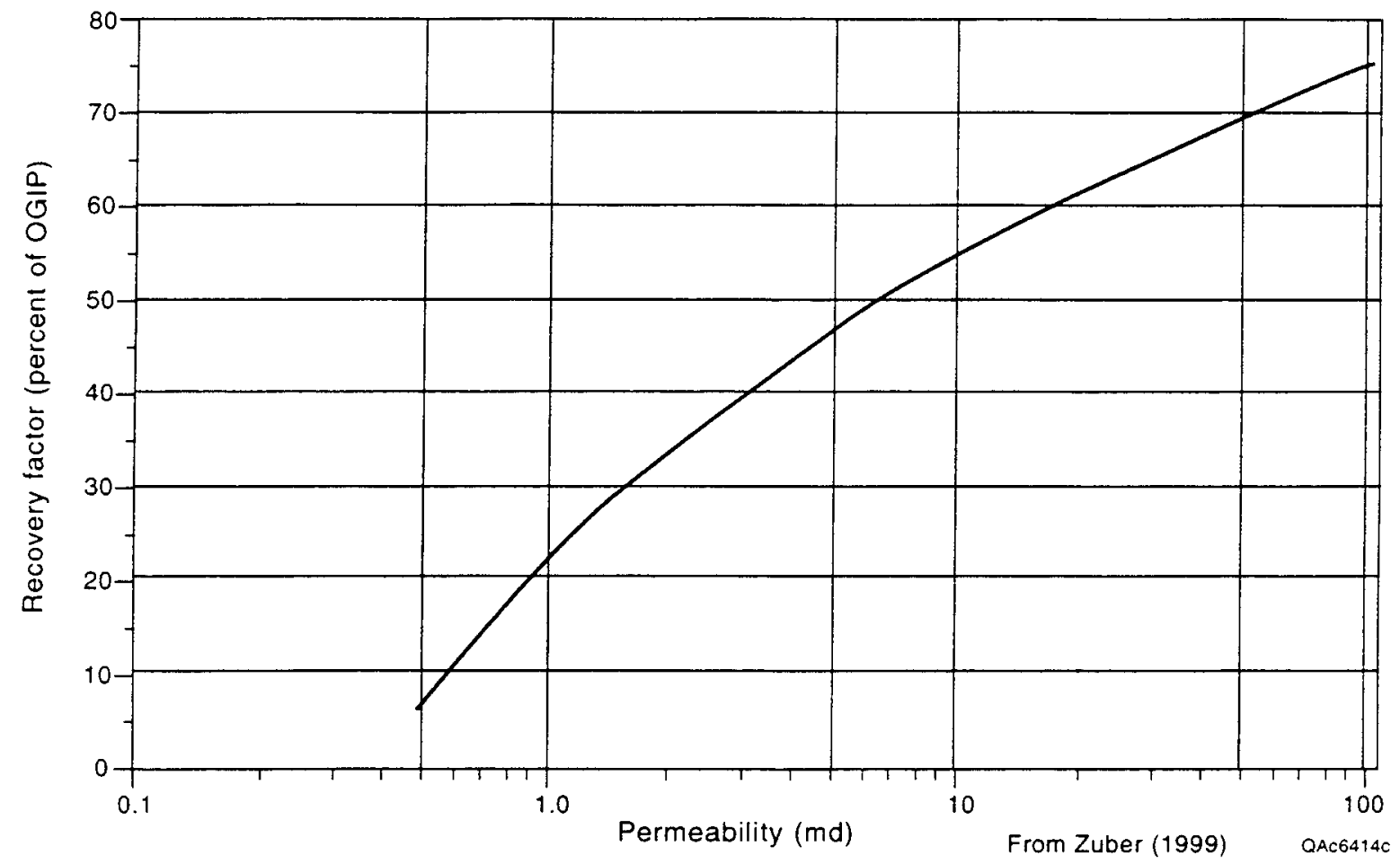

Figure 7 . The effect of permeability on recovery efficiency in coalbed methane wells (Zuber, 1999). 


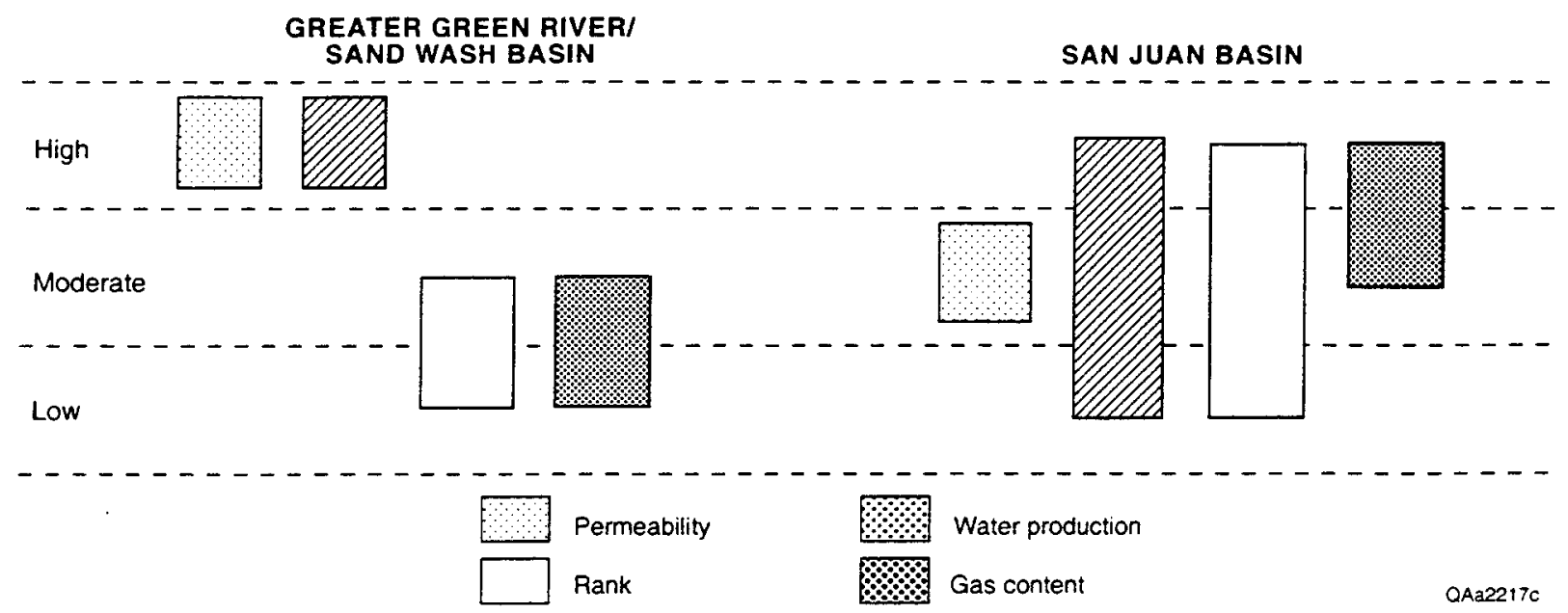

Figure 8. Characteristics of key geological and hydrological controls overlap in the San Juan and Sand Wash Basins. From Kaiser and others (1994b). 
(a)

\section{San Juan Basin}

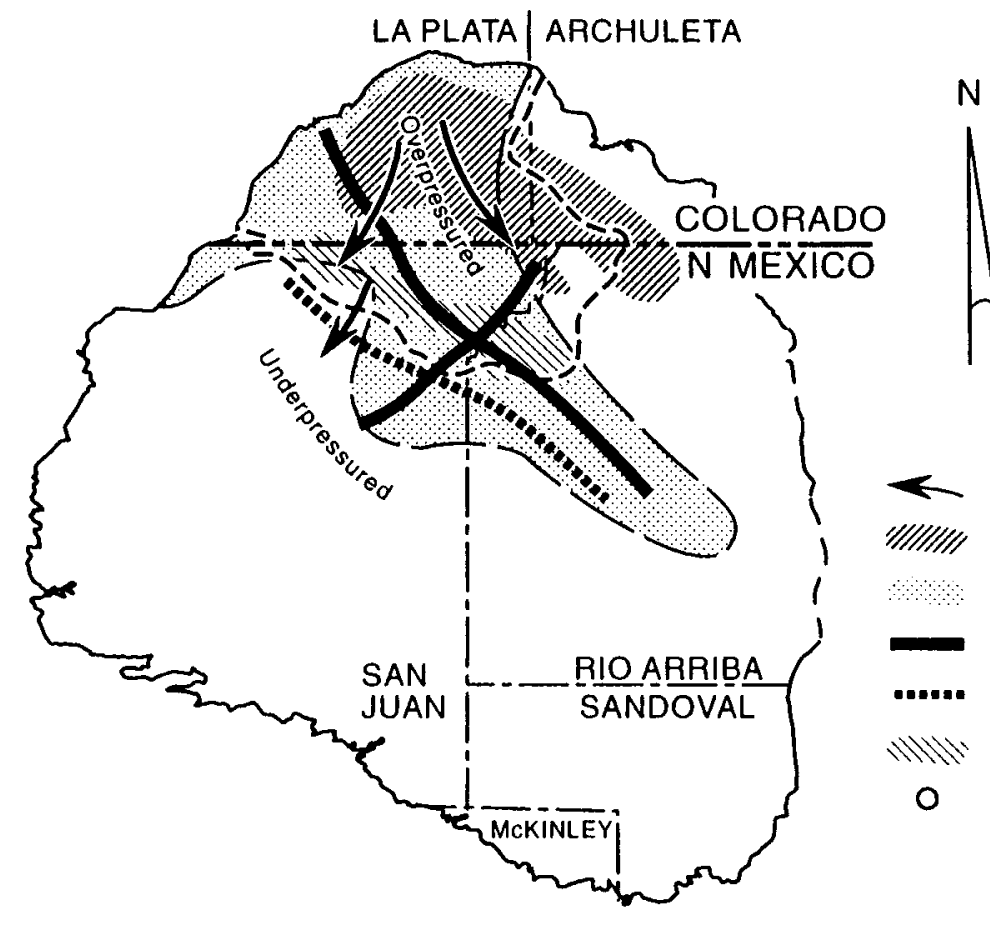

arl (b)

\section{Sand Wash Basin}

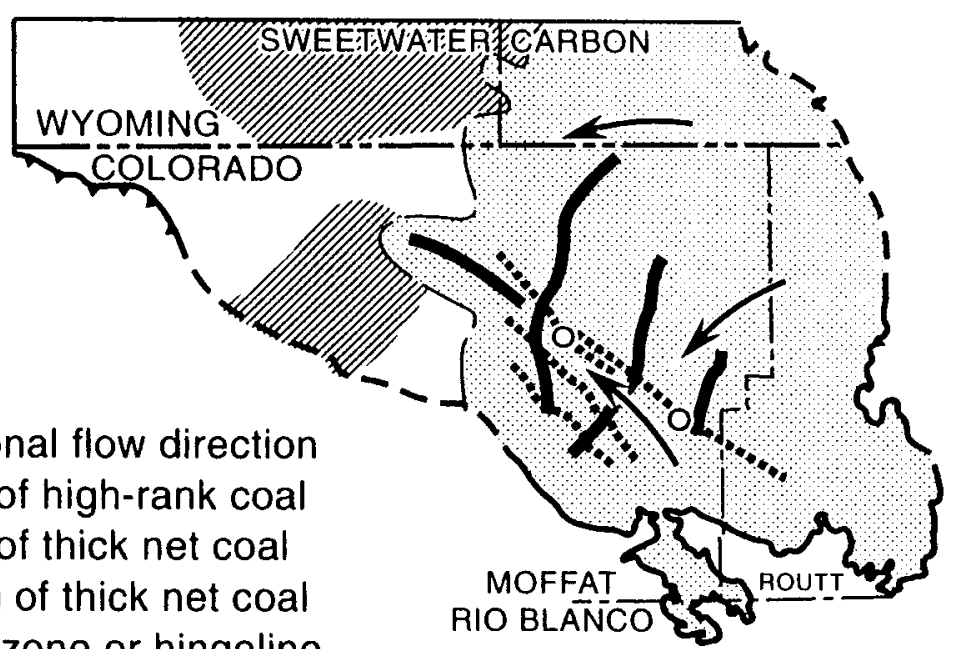

Regional flow direction

Area of high-rank coal

Area of thick net coal

Trend of thick net coal

Fault zone or hingeline

Area of high gas production

High-gas content well

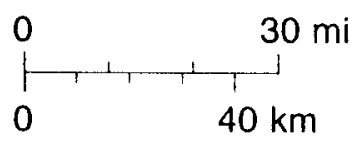

QAa2664c

Figure 9. Geologic and hydrologic comparison of the San Juan and Sand Wash Basins. In the San Juan Basin, a hydrodynamic trap exists along a structural hingeline. Conventionally trapped gas and high coalbed permeability explain high gas production and relatively low water production at this point in the basin. In the Sand Wash Basin, flow is toward and along a leaky, regional thrust-fault system. Lack of seals and permeability contrasts limit the potential for conventional trapping of gas. From Kaiser and others (1994a). 


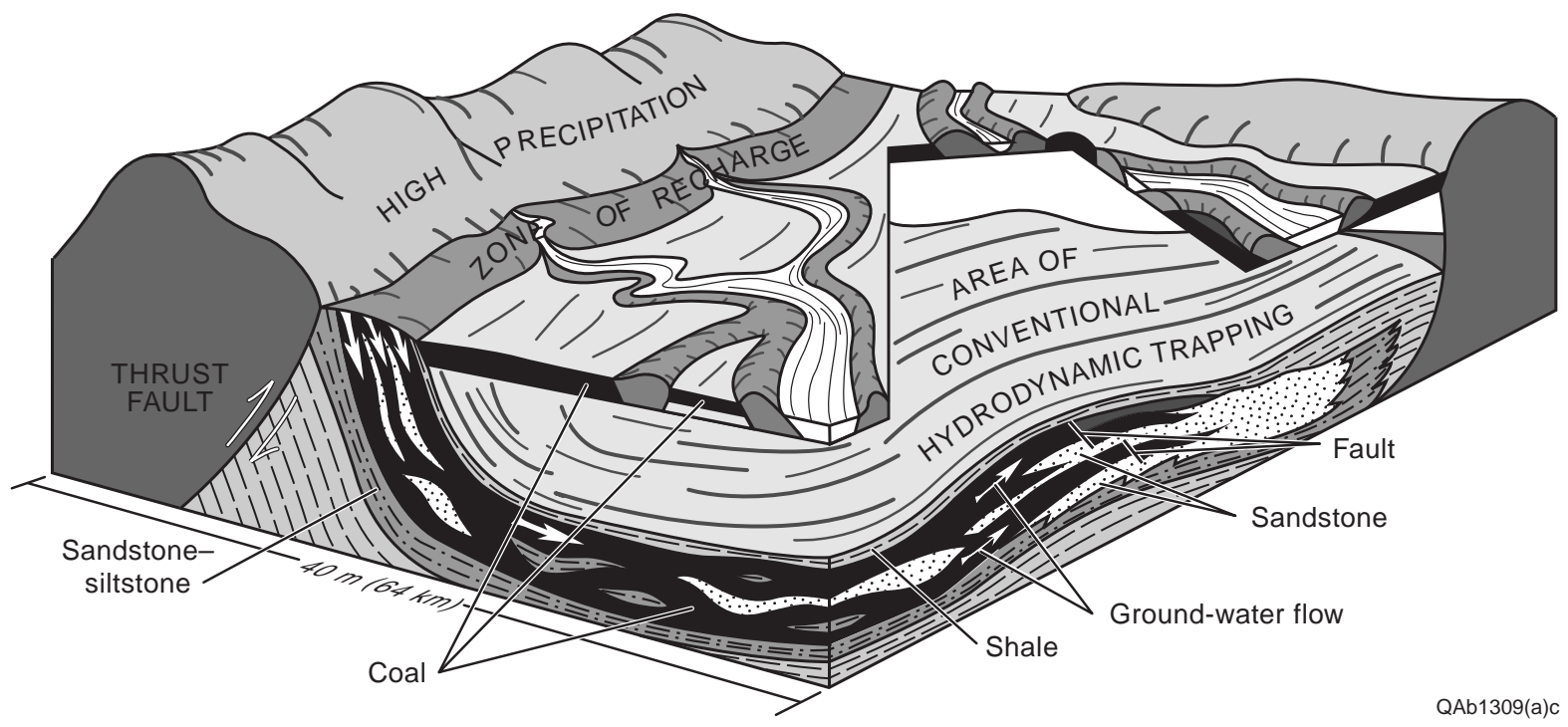




\section{Drilling, Production, and Reservoir Studies}


Guidelines for Designing Water Disposal Systems for Coalbed Methane Production in Alaska

David 0. Ogbe

University of Alaska, Fairbanks 


\section{Speaker Biography}

\section{David 0. Ogbe}

David 0. Ogbe is Professor of Petroleum Engineering and Acting Associate Director of the Petroleum Development Laboratory at the University of Alaska Fairbanks. He holds B.S. and MS. degrees from Louisiana State University and $\mathrm{Ph} . \mathrm{D}$. degree from Stanford University, all in petroleum engineering.

His research and consulting interests are in well test analysis, reservoir simulation, reservoir engineering, reservoir characterization, high performance computing and large-scale mathematical modeling. He is registered professional engineer in Alaska, and member of Society of Petroleum Engineers (SPE), SPWLA, and the Petroleum Society of the CIM. 


\section{Guidelines for Designing Water Disposal Systems for Coalbed Methane Production in Alaska.}

In this paper, we evaluate four methods of water disposal with a view to assessing their applicability to coalbed methane production in Alaska. The objective of this study is to recommend guidelines for designing water disposal and management systems for coalbed methane production in remote arctic environments. The methods evaluated are (1) direct discharge onto the surface, (2) controlled discharge into streams, (3) underground injection using wells, (4) use of freeze-thaw/evaporation systems.

We ranked the water disposal alternatives using a set of criteria including logistics and engineering challenges of water treatment and processing in the arctic, environmental regulations, costs of installation, operations and maintenance. We conclude that surface discharge by use of ground sprinklers is not acceptable in Alaska. The use of injection wells and the freeze-thaw/evaporation processes hold promise for dewatering coalbed methane wells in rural Alaska. We present a case study of underground water injection to demonstrate that subsurface injection wells are the preferred choice for water disposal during coalbed methane production in Alaska. 
Guidelines for Designing Water Disposal Systems for Coalbed Methane Production in Alaska

\author{
David O. Ogbe
}

Petroleum Development Laboratory

University of Alaska Fairbanks 


\section{Introduction}

$\checkmark$ Coal bed methane $(\mathrm{CBM})$ is produced from coal seams-- naturally fractured, low pressure, water saturated gas reservoirs

$\diamond$ Proper dewatering of the coal seams is a critical factor in methane gas production

$\checkmark$ Removing saline water trapped in coal seams

- reduces the formation pressure

- allows gas to desorb from coal seams and flow to wells 


\section{Coalbed Methane Well Performance}

Typical Production Profile

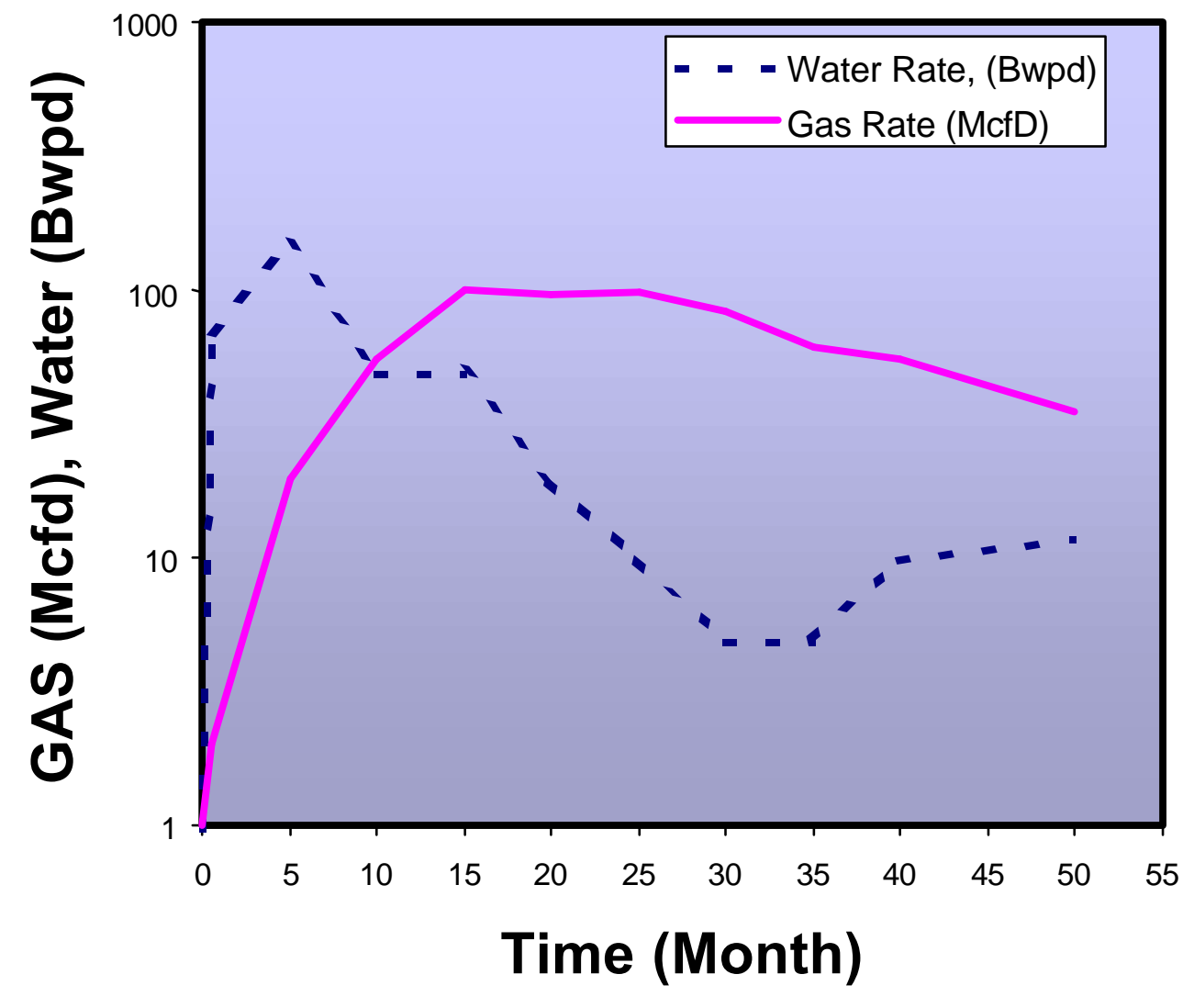




\section{Dewatering coalbed methane wells}

$\Delta$ Large amounts of water production in the early life of producing CBM wells

$\checkmark$ The early phases of high water production and low gas recovery may last for a period of six months to 3 years.

$\checkmark$ Dewatering period depends on:

- Permeability of the coal seams

- Well spacing and interference with other wells

- Presence of adjoining aquifer

- Past mining activity in the area may have depleted water in the coal seams 


\section{Statement of the Problem}

$\checkmark$ Are the current methods of water disposal applicable to the production of coalbed methane wells in Alaska?

- Cost effective?

- Environmental regulations?

- Arctic climate and logistics? 


\section{Objectives of the Study}

$\checkmark$ To review the methods available for CBM water disposal.

$\checkmark$ To evaluate the applicability of each method to the Arctic

$>$ To suggest design parameters and guidelines for designing water disposal systems. 


\section{Water Disposal Methods}

$\diamond$ Review several water disposal methods

$\diamond$ Evaluate three methods to determine if they can be applied in Alaska

- Surface Discharge

- Freeze/Thaw/Evaporation

- Underground Injection

$\checkmark$ Water disposal costs vary from $\$ 0.05$ to $\$ 2$ per barrel in the Lower 48 


\section{Surface Discharge}




\section{Advantages of Surface Discharge}

$\Delta$ Relatively low operating and maintenance costs in warm/temperate environments

$\checkmark$ Little or no harmful byproducts associated with the treatment of the waste water

$>$ Large volumes of water can be disposed of quickly 


\section{Limitations of Applying Surface Discharge to Alaska}

$\checkmark$ Extensive surface treatment facilities may be required depending on initial water quality

- Insufficient stream flow rates in winter to permit discharge of the effluent --treated water

- Strict environmental regulations.

$\checkmark$ Size of infrastructure, large surface foot prints limit application to Alaska 


\section{Freeze/Thaw/Evaporation}

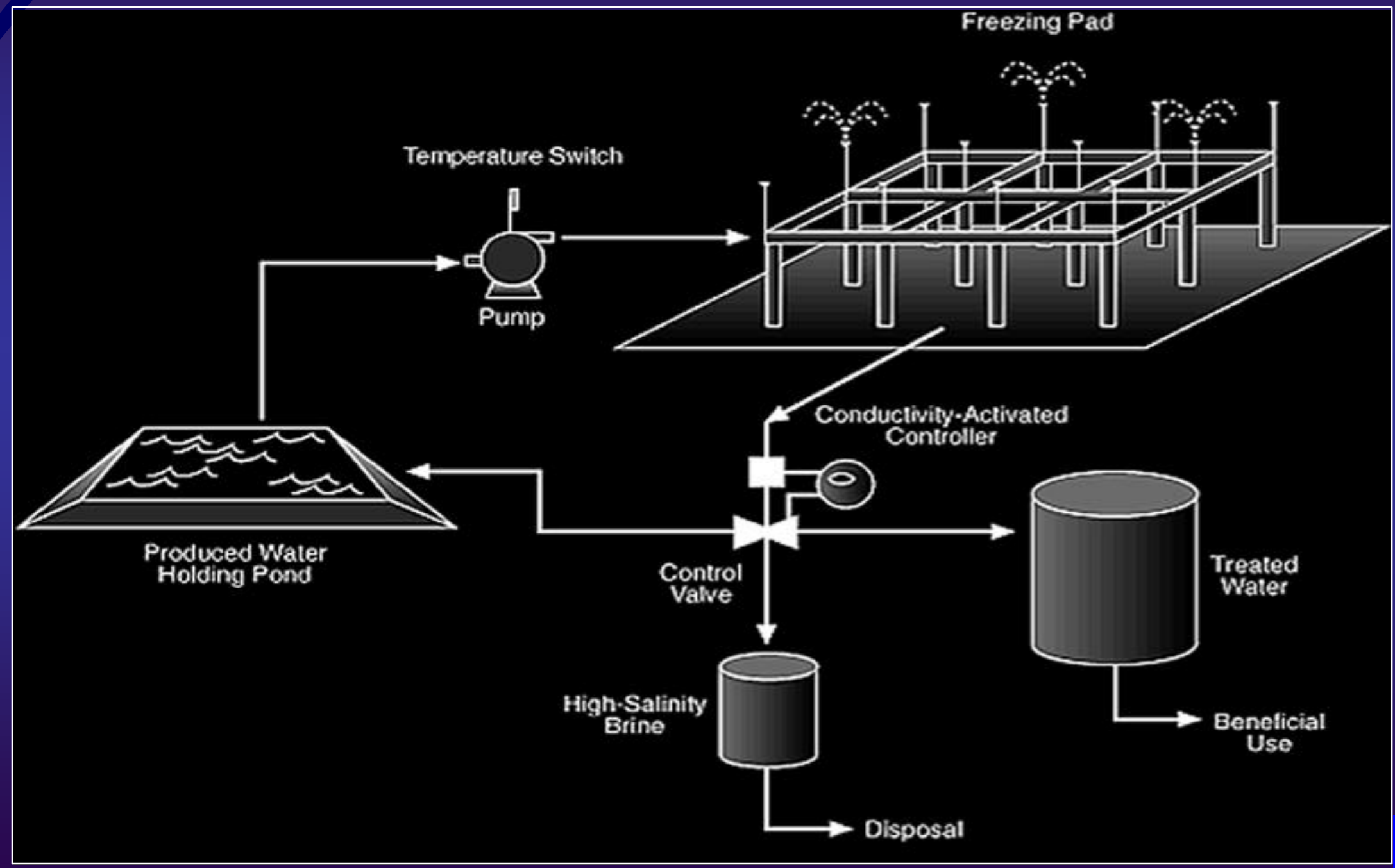


*-Ice Buildup on Framework of Freezing Pad

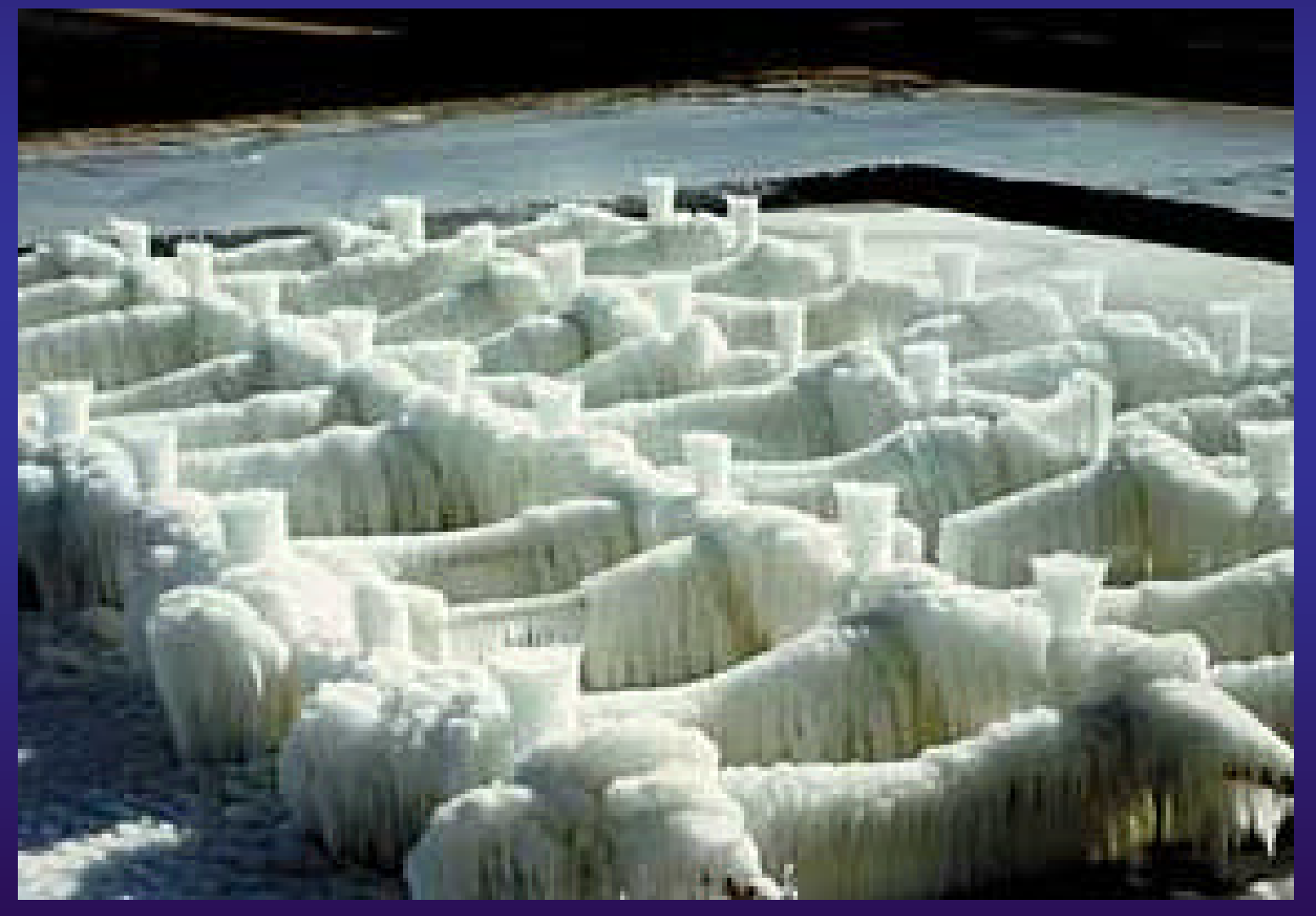




\section{Advantages of Freeze/Thaw Evap.}

$\checkmark$ Superior to conventional evaporation technology in cold climates with subfreezing temperatures

$\Delta$ Uses the cold ambient temperatures to freeze produced water

$\checkmark$ After freezing-thaw cycle, roughly $53 \%$ of produced water is portable, $27 \%$ is evaporated, leaving only $20 \%$ with high TDS (total dissolved solids) 


\section{Limitations and Modifications of FTE Process for Alaska}

$\checkmark$ For Alaska operations, Freezing Pad must be roofed to

(a) prevent heavy snowfall buildup on sprinkler system

(b) reduce solar heating on marginal freezing days

$\checkmark$ Problem of disposal of high salinity brine

$\checkmark$ Insufficient warm temperatures in some areas of Alaska to melt purified ice piles from an extended freezing period 
*-Advantages of Underground Injection

$\Delta$ Easy to design and maintain

$\Delta$ Little or no treatment infrastructure

$\checkmark$ High water disposal rates, depending on formation characteristics

$\diamond$ Knowledge and Technology transfer from oil \& gas production in the arctic environment 


\section{Challenges of Underground Injection}

$\diamond$ Danger of fluid communication between zones

$\diamond$ Disposal rates depend on formation characteristics of the Injection zones

- Permeability, porosity, fracture gradients.

$>$ Compatible Properties of water (Injected water quality versus Existing formation water quality)

$\diamond$ Permafrost 


\section{Case Study}

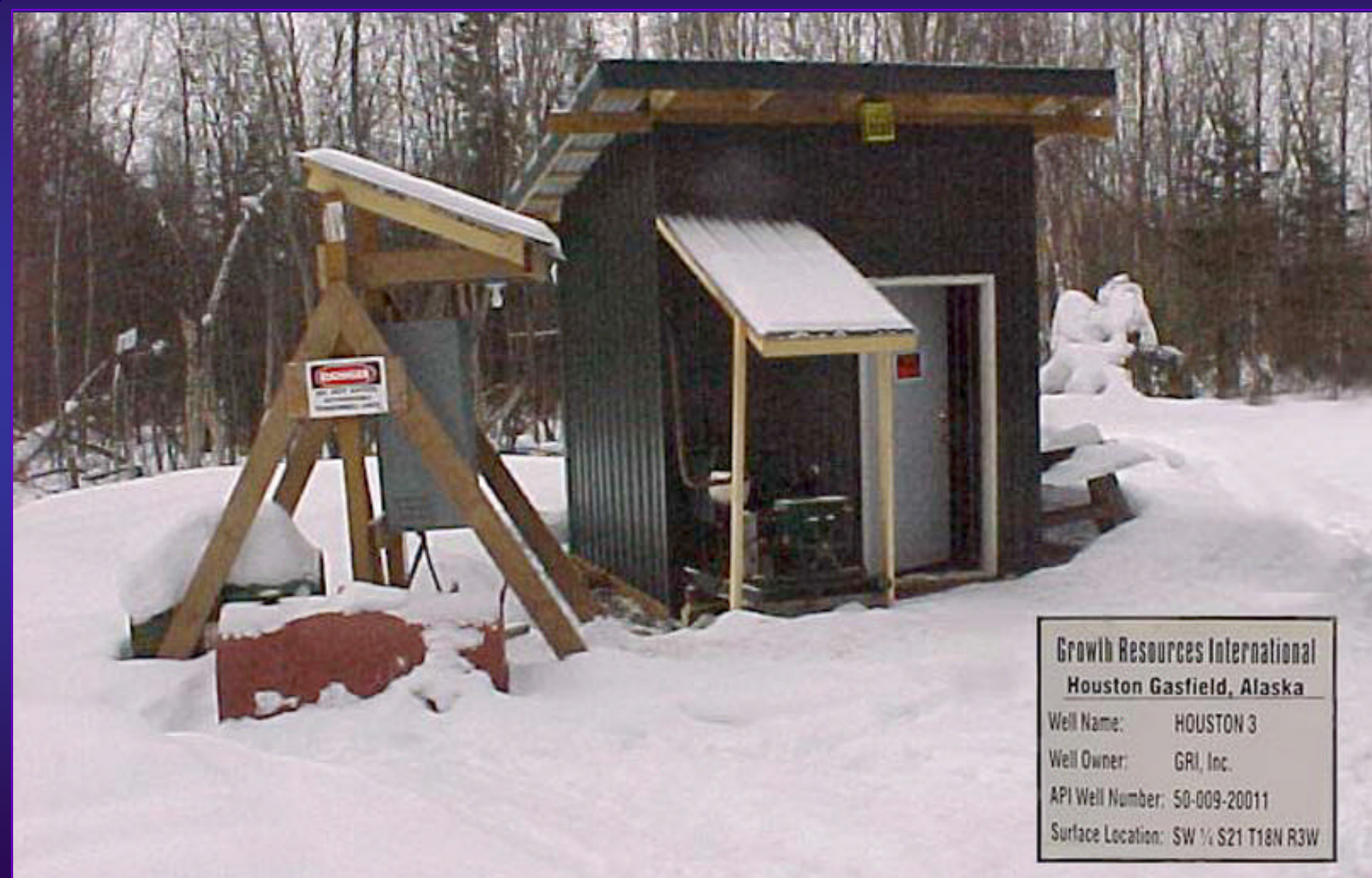




\section{Houston Well Case Study}

$\checkmark$ Mechanism for dewatering

- Reverse driven downhole progressive cavity pump mounted on a packer in a tubingless completion

$\checkmark$ Currently dewatering by producing 500 bbls of water per day

$>$ Project Costs:

- \$250K/well (drill), \$50K/well (wellhead equip.), and $\$ 1,430 /$ month for supplies and personnel 


\section{Design Parameters}

$\checkmark$ Determine field water disposal requirements

- Production start-up schedule--when will the wells be drilled, completed? Begin producing gas?

- Water flow rate from all the wells planned for field development

- Rate variation in well production rates during the life of the field--Production Decline Analysis 


\section{Design Parameters, 2}

$\checkmark$ Determine water quality

$>$ Characteristics of the injection zones for underground disposal wells

$\checkmark$ Determine permeability, well spacing, pump rates

$\Delta$ Environmental regulations

$>$ Permafrost

$\diamond$ Installation, maintenance and operating costs 


\section{Summary}

$\checkmark$ Analysis suggests that water disposal system such as Freeze/Thaw/Evaporation which utilizes the cold in the Arctic may hold promise in some regions of Alaska

- Surface disposal methods are not applicable

$\checkmark$ The use of disposal wells is the preferred method of choice for dewatering wells producing coalbed methane in Alaska 


\section{Acknowledgements}

$\checkmark$ Mike Triolo carried out the data collection

$>$ Dave Lappi provided data for Houston case study

$\checkmark$ Jim Clough for his cooperation and support of the our coalbed methane research program 


\section{Outline}

$\checkmark$ Introduction

$\checkmark$ Study Objectives

$\checkmark$ Evaluation of Water Disposal Methods

$\checkmark$ Summary of Design Parameters

$>$ Conclusions 


\section{* Surface Treatment and Direct Discharge into Streams}

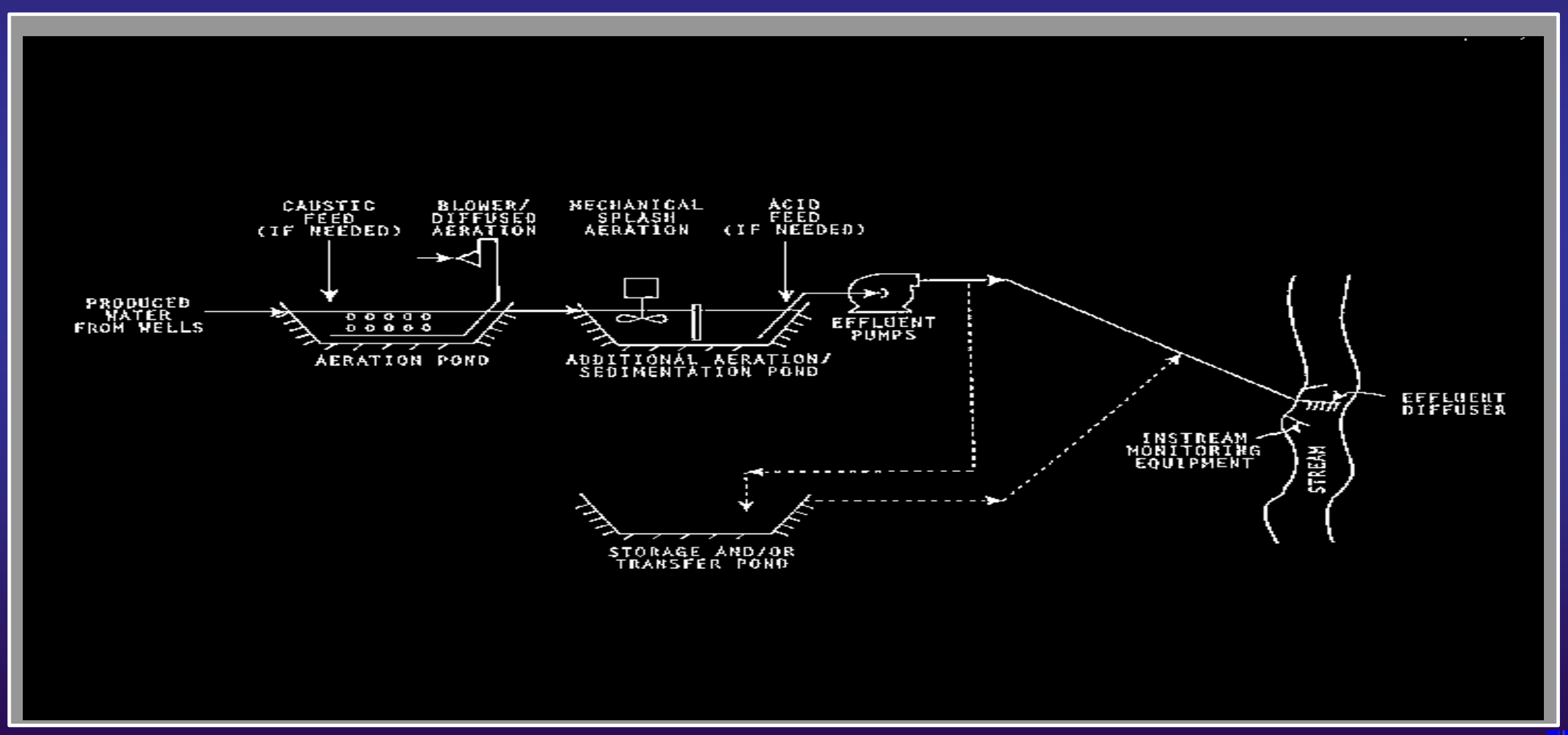

Source: Davis et al, 1993 
*-Dual Production \& Brine Disposal Well

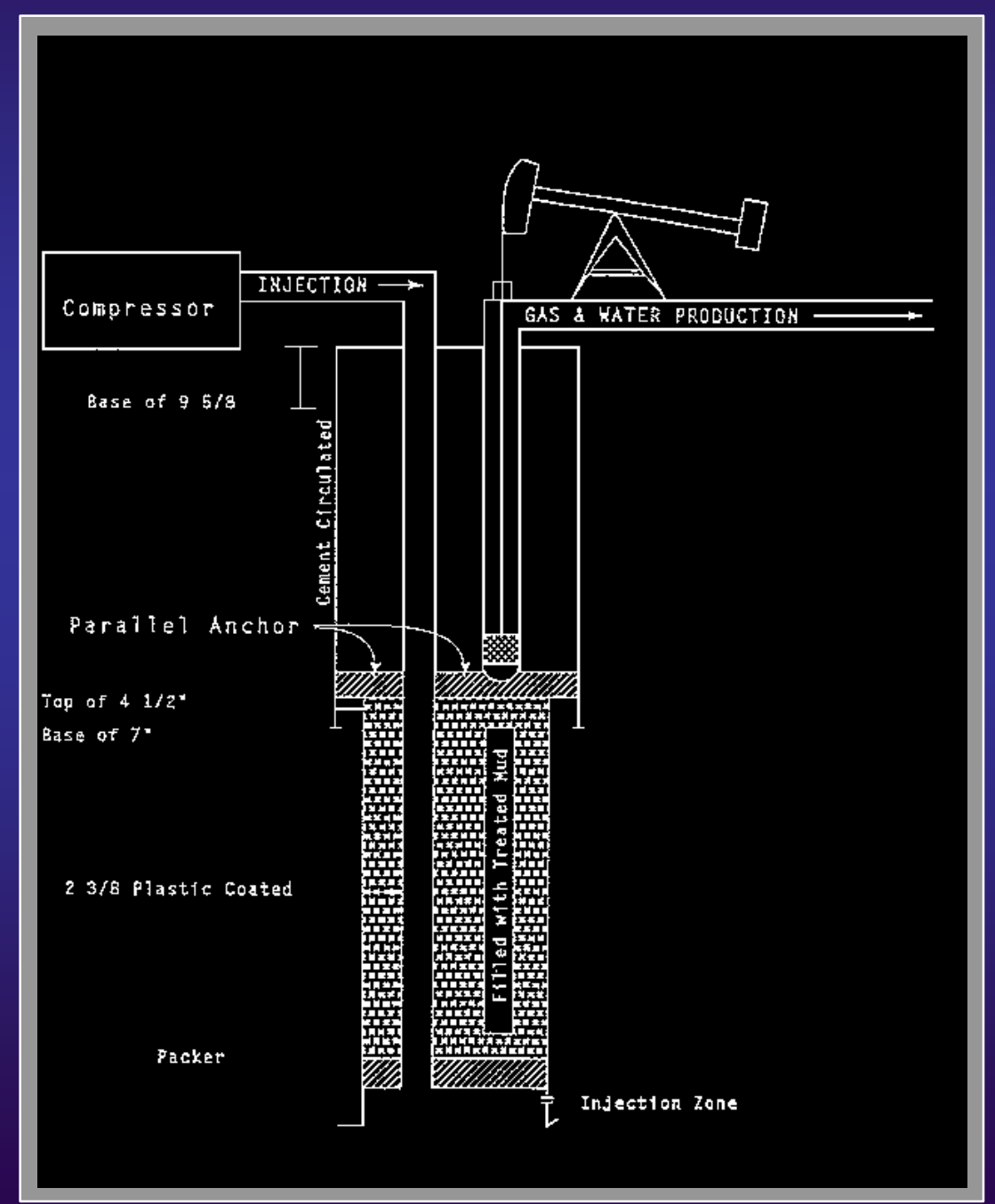

Source:

Zimpfer et al, 1988 


\section{Microhole Drilling and Instrumentation Technology}

Jim Albright

Los Alamos National Laboratory 


\section{Speaker Biography}

\section{Jim Albright}

Jim Albright is leader of the GeoEngineering Group at Los Alamos National Laboratory, New Mexico, an interdisciplinary science and engineering group engaged in rock mass characterization for oil, geothermal, and national security programs. Included in the work underway in the Group are research and development activities in borehole logging, non-conventional drilling, seismic imaging of complex geological structures, and non-linear acoustics of rock. Jim joined Los Alamos in 1974 where he participated in the development, characterization, and operation of the worlds first artificial geothermal reservoir at Fenton Hill, NM. His research has been in the area of borehole seismics applied to reservoir imaging and fracture mapping. Jim holds a PhD in Geophysical Sciences from the University of Chicago. 


\section{Microhole Drilling and Instrumentation Technology}

Los Alamos in collaboration with the oil industry through the U. S. Department of Energy's Natural Gas and Oil Recovery Partnership, has undertaken an integrated program of development to show that the cost of obtaining subsurface information can be drastically reduced through microhole technologies expressly developed to obtain that information. Because of the greatly reduced size and consequent portability of microhole drilling and logging equipment, this technology offers an attractive option for the characterization of coalbed methane resources in Alaska. Collectively termed "Microhole Drilling and Instrumentation Technology," the Los Alamos engineering efforts encompass drilling of shallow microholes using currently available coiled tubing technology, evaluating the feasibility of drilling deep microholes, miniaturization and testing of bottomhole drilling assemblies, miniaturization of geophysical logging tools, and incorporation of emerging miniature sensor technologies in borehole seismic instrumentation packages. Microhole technology development is based on the premise that because of the historic advances in electronics and sensors, conventional-diameter wells are no longer necessary for obtaining subsurface information. Thus, the projected combination of microholes having terminal-depth diameters of 2-3/8 to 1-3/8 inches and logging tools having a diameter of 7/8 inch will offer a very low cost alternative to currently available technology for exploration and reservoir characterization. 


\section{A Potential Method for Assessing Coalbed Methane Resources Using High-Resolution Chronostatigraphy, Vitrinite Reflectance and Burial History Modeling. Cook Inlet, Alaska (Poster)}

Todd A. Dallegge

University of Alaska, Fairbanks 


\section{A Potential Method for Assessing Coalbed Methane Resources Using High-Resolution Chronostratigraphy, Vitrinite Reflectance and Burial History Modeling, Cook Inlet, Alaska}

Natural gas reserves in conventional traps are well known in Alaska, but methane reserves in coalbeds associated with these gas fields remain undetermined. Due to declining conventional gas reserves in the Cook Inlet basin, the State of Alaska and the USGS are interested in promoting studies of environmentally favorable alternate energy sources. Methane stored in coalbeds can be modeled if the burial history, rank of the coals (i.e., gas generated), shallow structure (gas traps), and depth to the coals (pressure acting to hold gas in) are known. Changes in burial depth, erosion rates, and geothermal gradient affect the distribution of vitrinite reflectance (Ro) values, methane formation, and potential storage in coal beds. Therefore, a complete understanding of the stratigraphic relations is necessary to adequately assess methane production. These factors make the Cook Inlet Basin an ideal setting to document and test a high-resolution, thermal maturation model for coalbed methane resource potential.

I propose the construction of a model for assessing the coalbed methane potential of the Kenai Group in Cook Inlet Basin. Ash bed partings in coalbeds and Ro samples from coalbeds and coaly fossils will be collected from core and outcrop. ${ }^{40} \mathrm{Ar} /{ }^{39} \mathrm{Ar}$ dating and Ro measurements will be completed on these samples. Published data, including well logs, regional tectonic studies, coal-quality, and seismic data, will be used to supplement this information.

The data produced by the methods above will be used to formulate a chronostratigraphic and thermal framework of the basin. Multiple ${ }^{40} \mathrm{Ar} /{ }^{39} \mathrm{Ar}$ dates will allow for complete correlation and delineation of stratigraphic relations between wells and outcrops across the basin. Ro measurements will determine the thermal histories at these locations. Basinmod software will be used to determine the burial history of the basin. Using this data, a model will be constructed to produce basin-wide, maturity isopach maps showing areas of potential coalbed methane generation and storage. These isopach maps will be used to assess coalbed methane reserves and may be used for future resource production planning. 
Evaluation of Coalbed Methane Prospects Near Wainwright, Alaska, Using Burial History Modeling of The Western National Petroleum Reserve In Alaska (NPRA) (Poster)

Ron Tingook Arctic Slope Regional Corporation

Charles E. Barker

U.S. Geological Survey 


\title{
Evaluation Of Coal Bed Methane Prospects Near Wainwright, Alaska, Using Burial History Modeling Of The Western National Petroleum Reserve In Alaska (NPRA)
}

BY

\author{
Ron Tingook, Arctic Slope Regional Corporation, 301 \\ Arctic Slope Avenue, Suite 300, Anchorage, Alaska 99518 \\ and \\ Charles E. Barker, USGS, box 25046, MS 977, Denver, \\ Colorado 80225
}

The Coal Bed Methane gas potential of Cretaceous Nanushuk group coals located in the Western National Petroleum Reserve in Alaska (NPRA) and in particular near the Native village of Wainwright were evaluated using burial history models to evaluate coal rank and gas content. Using this model, published geologic and geographic data, and onsite field investigations, The Alaska Division of Geological and Geophysical Surveys and U.S. Geological Survey will assess gas prospects for Wainwright before implementing a drilling program.

The Nanushuk group of Early Cretaceous to early Late Cretaceous (Sable and Stricker, 1987) is a marine and non-marine deltaic deposit underlies nearly all of NPRA. The Nanushuk group sediments were derived from two principle source areas, one SE of Umiat and the other W of NPRA near Corwin Bluff, and prograde northeasterly across NPRA becoming younger at the distal end. It's northern extent is an erosional truncation south of Barrow, and to the east extends beyond the Eastern border of NPRA defined by the Colville River. In the southwestern NPRA, it is approximately 3000 meters thick, thinning to less than $300 \mathrm{~m}$ at the Colville River delta in the East (Mayfield, et al, 1983). In the western NPR4, Huffman et al. (1981), show that the Nanushuk was deposited in the Corwin delta, and can be broken into three facies: marine, transitional, and nonmarine. The numerous coal beds, some of which are up to 4 meters thick, are present only in the inter-distributary deposits of the non-marine facies on the middle to upper-delta plain. Stratigraphically, it conformably overlies the Torok formation and underlies lies the Shale of the Colville Group, the Sandstone of the Colville Group, the Sagavinirktok formation, and finally the surficial Gubik formation (Bird, 1985).

The burial history models are based on this stratigraphy and a cross section developed from 2D Seismic data coupled with well log data taken from eight wells whose locations define a SW-NE trending line across the western Colville Basin from its southern foothills province to its northern extent on the Barrow Arch. Vitrinite Reflectance (Ro) versus Depth data for each well was used to constrain a burial history model in BasinMod 1D®. The Ro value for the coal underlying Wainwright was extrapolated from the produced cross-section. Further studies of coal samples taken from outcrops to the north of Wainwright will be used in conjunction with the findings of this report to further evaluate the gas production potential. 
Using BasinMod, a burial history of the Colville basin, from the lower Jurassic Kingak shale to present day surface, was produced by using published age, estimated true-thickness, Ro values taken from different depths, and well log lithology data. From the burial history, a thermal history was created and Ro values were calculated for each well location (see figures below). Focus remains on the non-marine Nanushuk group. The estimated Ro value for the Wainwright area is in the early mature window with respect to gas generation.

In conclusion, our modeling and cross-section along with other published data shows that the Wainwright area has the potential for on the order of 75 net feet of mixed biogenic and thermogenic gas-bearing coal with at least a sub-bituminous rank and likely a bituminous rank at less than $2500 \mathrm{ft}$. beneath the village.

\section{References}

Bird, K., J., 1985, North Slope Stratigraphic Nomenclature and Data Summary for Government-Drilled Wells, in Gryc, G., ed., Geology and Exploration of the National Petroleum Reserve in Alaska, 1974 to 1982: United States Geological Survey professional paper 1399, p. 331.

Huffman, A. C., Jr., Ahlbrandt, T. S., and Bartsch-Winkler, S., 1981, Sedimentology of the Nanushuk Group, North Slope, in Gryc, G., ed., Geology and Exploration of the National Petroleum Reserve in Alaska, 1974 to 1982: United States Geological Survey professional paper 1399, p. 283-288.

Mayfield, C.F., Tailleur, I.L., and Kirschner, C.E., 1983, Bedrock Geologic Map of the National Petroleum Reserve in Alaska, in Gryc, G., ed., Geology and Exploration of the National Petroleum Reserve in Alaska, 1974 to 1982: United States Geological Survey professional paper 1399, p. 187-1 89.

Sable, E.G. and Stricker, G.D., 1987, Coal in the National Petroleum Reserve in Alaska (NPRA): Framework Geology and resources, in Tailleur, I., and Weimer, P., eds., Alaska North Slope Geology volume one, Pacific Section, SEPM Guidebook, p. 195-215. 
Attendance List 


\section{Alaska Coalbed Methane Workshop 2000 Participants}

\begin{tabular}{|c|c|c|c|c|c|}
\hline Last Name & First Name & Company & City & Phone & e-mail \\
\hline Albright & Jim & Earth \& Env. Sciences Div. & Los Alamos & $(505) 667-4318$ & j_albright@lanl.com \\
\hline Ausbrooks & Robin & Barrett Resources Corporation & Denver & (303)606-4273 & rausbrooks@brr.com \\
\hline Banet & Art & Bureau of Land Management & Anchorage & (907)271-6563 & arthur.banat@mms.gov \\
\hline Barker & Charles & USGS & Denver & (303)236-5795 & barker@usgs.gov \\
\hline Barrett & Terry & Barrett Resources Corporation & Denver & (303)606-4053 & tbarrett@brr.com \\
\hline Bates & Pirtle & AK Div. of Oil \& Gas & Anchorage & (907)269-8810 & pbj@dnr.state.ak.us \\
\hline Bendersky & Mark & AK Science and Tech. Found. & Anchorage & N/A & mbendersky@astf.org \\
\hline Billings & John & Galena School District & Galena & (907)656-1205 & jeno@galenanet.com \\
\hline Bond & Andy & Arco Alaska Inc. & Anchorage & (907)263-4623 & abond@email.arco.com \\
\hline Booth & Gerald & DGG Booth \& Associates & Greenacres & (509)927-7488 & jjhome@ior.com \\
\hline Buthman & David & Unocal & Anchorage & N/A & buthbdb@unocal.com \\
\hline Christenson & Bob & AK Oil \& Gas Conservation Co. & Anchorage & $(907) 793-1221$ & robert_christenson@admin.state.ak.us \\
\hline Clough & Jim & AK Div of Geol. \& Geoph. Survey & Fairbanks & $(907) 451-5030$ & jim@dnr.state.ak.us \\
\hline Conrad & Gary & Rosewood Resources Inc. & Dallas & $(214) 756-6617$ & gary_conrad@rosewd.com \\
\hline Coughlin & Patrick & AK Div of Oil \& Gas & Anchorage & N/A & N/A \\
\hline Cowan & Jim & AK Div. of Oil \& Gas & Anchorage & (907)269-8765 & jim_cowan@dnr.state.ak.us \\
\hline Crimp & Peter & Alaska Energy Authority & Anchorage & (907)269-4631 & pcrimp@aidea.org \\
\hline Crow & Don & Lufkin Industries, Inc. & Houston & (713)468-7804 & doncrow@lufkin-houston.com \\
\hline Dallegge & Todd & University of Alaska-Fairbanks & Fairbnaks & $(907) 474-7585$ & fttad@uaf.edu \\
\hline Davies & Steve & AK Oil \& Gas Conservation Co. & Anchorage & (907)793-1244 & steve_davies@dmin.state.ak.us \\
\hline Downey & Bobert & Ocean Energy & Littleton, Co. & (303)308-8822 & rob.downey@oceanenergy.com \\
\hline Eggan & Andy & Alaska Power \& Telephone & Haines & $(907) 766-2331$ & apthlp@ptialaska.net \\
\hline Ehm & Arlen & Arlen Ehm-Geologic Consulting & Anchorage & (907)333-8880 & arlenehm@gci.net \\
\hline Enos & Nick & Calista Corporation & Anchorage & (907)279-5516 & nenos@calistacorp.com \\
\hline Ershaghi & Iraj & West Coast PTTC & Los Angeles & (213)740-0321 & ershaghi@earthlink.net \\
\hline Fisk & Bob & US Bureau of Land Management & Anchorage & (907)271-4407 & bfisk@ak.blm.gov \\
\hline Foley & Jeff & Calista Corporation & Anchorage & (907)279-5516 & jfoley@calistacorp.com \\
\hline Ford & Gary & Anadarko Petroleum Corp. & Anchorage & (907)563-9478 & gary_ford@anadarko.com \\
\hline Freeze & David & Lufkin Industries, Inc. & Bakersfield & $(661) 327-3563$ & dfreeze@worldnet.att.net \\
\hline Garaven & Eric & Unocal & Anchorage & (907)263-7837 & gravene@unocal.com \\
\hline Gardner & Paul S. & Marathon Oil Co. & Anchorage & N/A & psgardner@marathonoil.com \\
\hline
\end{tabular}




\begin{tabular}{|c|c|c|c|c|c|}
\hline Last Name & First Name & Company & City & Phone & e-mail \\
\hline Glavinovich & Paul S. & Nana Development Corp. & Anchorage & $(907) 345-3646$ & glav@worldnet.att.net \\
\hline Green & Joe & Alaska State Legislature & Anchorage & $(907) 465-4931$ & representative_joe_green@legis.state.ak.us \\
\hline Hartner & John & Anadarko Petroleum Corp. & Anchorage & $(907) 563-9490$ & john_hartner@anadarko.com \\
\hline Hartz & Jack & AK Oil \& Gas Conservation Co. & Anchorage & $(907) 793-1232$ & jack_hartz@admin.state.ak.us \\
\hline Havelock & Brian & State of Alaska, ADNR & Anchorage & (907)269-8807 & brian_havelock@dnr.state.ak.us \\
\hline Heinze & Harold & Ahtna Minerals Co. & Anchorage & $(907) 868-8216$ & heinze@takas.com \\
\hline Houle & Julie & AK Div. of Oil \& Gas & Anchorage & (907)269-8773 & jah@dnr.state.ak.us \\
\hline Ice & Geoff & Rosewood Resources Inc. & Dallas & $(214) 756-6637$ & geoff_ice@rosewd.com \\
\hline Imm & Theresa & Arctic Slope Regional Corp. & Anchorage & (907)267-6372 & timm@asrc.com \\
\hline Jameson & Bret & Ocean Energy & Houston & (713)265-6812 & bret.jameson@oceane energy.com \\
\hline Lambertsen & Ken & Van Waters \& Rogers Inc. & Anchorage & (907)344-7444 & ken.lambertsen@vwr-inc.com \\
\hline Lappi & David & LAPP Resources Inc. & Anchorage & (907)248-7188 & lapres@gci.net \\
\hline Lee & Carol & State of Alaska & Anchorage & (907)269-8813 & cdl@dnr.state.ak.us \\
\hline LePain & David & AK Div.of Geol. \& Geoph. Survey & Fairbanks & $(907) 451-5011$ & davele@dnr.state.ak.us \\
\hline Lou & Margret & US Dept. of Energy, NTP & Tulsa & N/A & mlou@npto.doe.gov \\
\hline Mahon & Donald & Alaska Power and Telephone & Tok & (907)883-5101 & donaptc@eagle.ptialaska.net \\
\hline Malinowsky & Mark & Rosewood Resources Inc. & Dallas & $(214) 756-6624$ & mark_malinowsky@rosewd.com \\
\hline Massengale & Marc & URS Greiner Woodward-Clyde & Anchorage & $(907) 561-1020$ & marc_massengale@urscorp.com \\
\hline Maunder & Thomas & AK Oil \& Gas Conservation Co. & Anchorage & $(907) 793-1250$ & tom_maunder@admin.state.ak.us \\
\hline Nason & Wes & Ahtna Minerals Co. & Anchorage & (907)868-8201 & wnason@ahtna-inc.com \\
\hline Nelson & Kristen & Petroleum News Alaska & Anchorage & (907)248-3622 & pnak@alaska.net \\
\hline Ogbe & David & University of Alaska-Fairbanks & Fairbanks & $(907) 474-7698$ & ffdoo@uaf.edu \\
\hline Paris & Chet & PRA, LLC. & Anchorage & (907)272-1232 & paris@gci.net \\
\hline Phillips & Norous & Doyon Limited & Fairbanks & $(907) 452-4755$ & phillipn@doyon.com \\
\hline Rader & Matthew & AK Dept. of Natural Resources & Anchorage & (907)269-8776 & matt_rader@dnr.state.ak.us \\
\hline Reeves & Scott & Advanced Resouces Int'l. & Houston & $(713) 780-0815$ & sreeves@adv.res.com \\
\hline Roberts & Wayne & Devon Energy Corp. & Oklahoma City & $(405) 552-4598$ & wayne.roberts@dvn.com \\
\hline Roehl & Paul & Bristol Bay Native Corp. & Anchorage & (907)278-3602 & roehlp@bbnc.net \\
\hline Saunders & Bryan & Ocean Energy & Houston & (713)265-6787 & bryan.staunders@ocean energy.com \\
\hline Schantes & David & Pason Systems USA Corp. & Golden & $(720) 880-2000$ & mary@pason.com \\
\hline Schmitz & Steven & AK Div. of Oil \& Gas & Anchorage & N/A & N/A \\
\hline Schrider & Leo & Belden \& Blake Corp. & North Canton & $(330) 499-1660$ & lschrider@beldenblake.com \\
\hline Scott & Andrew & Altuda Geological Consulting & Austin & $(512) 970-4407$ & Andrew@altuda.com \\
\hline Sherwood & Kirk & Minerals Mgmt. Serv. Res. & Anchorage & (907)271-6085 & fax-907-271-6805 \\
\hline Shively & John & AK Dept. of Natural Resources & Anchorage & $(907) 465-2400$ & john_shively@dnr.state.ak.us \\
\hline
\end{tabular}




\begin{tabular}{|c|c|c|c|c|c|}
\hline Last Name & First Name & Company & City & Phone & e-mail \\
\hline Stanek & Judy & AK Div. of Oil \& Gas & Anchorage & $(907) 269-8816$ & judy_stanek@dnr.state.ak.us \\
\hline Stanley & Richard & USGS & Menlo Park & (650)329-4918 & rstanley@usgs.gov \\
\hline Sweetsir & Russ & City of Galena & Galena & $(907) 656-1301$ & marviny@arctic.net \\
\hline Taylor & Cammy & AK Oil \& Gas Conservation Co. & Anchorage & $(907) 793-1250$ & cammy_oechli@admin.state.ak.us \\
\hline Torrence & Leslie & Bureau of Land Management & Anchorage & (907)271-4429 & ltorrence@ak.blm.gov \\
\hline Tyler & Roger & Bureau of Economic Geology & Austin & N/A & tyler@utexas.edu \\
\hline Valenzuela & Frank & West Coast PTTC & Los Angeles & (213)740-8076 & pttc@archie.usc.edu \\
\hline Van Dyke & Bill & Alaska Div. of Oil \& Gas & Anchorage & (907)269-8786 & wdv@dnr.state.ak.us \\
\hline Webb & Bruce & AK Div. of Oil \& Gas & Anchorage & $(907) 726-9877$ & bruce_webb@dnr.state.ak.us \\
\hline Widner & Danny & Rosewood Resources Inc. & Vernal & $(435) 789-0414$ & danny_widner@rosewd.com \\
\hline Williams & Anita & NANA/Dynatec Drilling & Anchorage & $(907) 345-2541$ & awilliams@micronet.net \\
\hline Wiltse & Milton & AK Div of Geol. \& Geoph. Survey & Fairbanks & $(907) 451-5010$ & milt@dnr.state.ak.us \\
\hline
\end{tabular}


PTTC West Coast Resource Center, HED-306

Petroleum Engineering Program

University of Southern California

Los Angeles, CA 90089-1211

Phone: (213) 740-8076 - Fax: (213) 740-7982

Prof. Iraj Ershaghi, Regional Director

Voice: (213) 740-0321

Fax: (213) 740-0324

e-mail: ershaghi@archie.usc.edu

Ms.Shahed Meshkati, Consultant

Voice: (213) 740-0016

Fax: (213) 740-7982

e-mail: smeshkat@usc.edu

Ms. Maria Valenzuela, Accounting

Voice: (213) 740-0322

Fax: (213) 740-0324

e-mail: office@,archie.usc.edu

Dr. Hossein Rassamdana, Research Associate

Voice: (213) 740-8076

Fax: (213) 740-7982

e-mail: rassamda@rcf.usc.edu

Mr. Frank Valenzuela, Consultant

Voice: (213) 740-8076

Fax: (213) 740-7982

e-mail: pttc@archie.usc.edu

Ms. Ana Rincon, Secretary

Voice: (213) 740-8076

Fax: (213) 740-7982

e-mail: pttc@archie.usc.edu

Mr. Hamid Cheheltani, Webmaster

Voice: (602) 957-3093

Fax: (602) 957-3093

e-mail:hamidc@,home.com 